J. E. Boysen, C. Y. Cha,

F. A. Barbour, T. F. Turnex, T. W. Kang,

M. H. Berggren, R. F. Hogsett, M. C. Jha

\author{
rebruary 1990 \\ Work Performed Under Contract DE-AC22-88PC88886 \\ For \\ U.S. Department of Inergy \\ Rittsburgh Energy Technology Center \\ Pittsburgh, PA 15236 \\ By \\ Western Research Institute \\ Laramie, WY 82071 \\ and \\ AMAX Research and Development Center \\ Golden, co 80403.7499
}




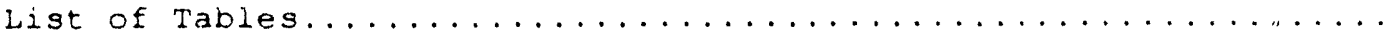

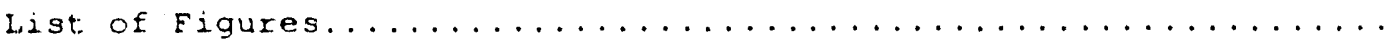

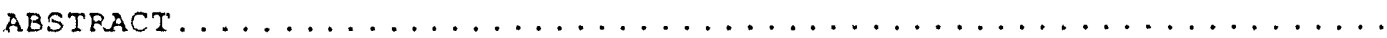

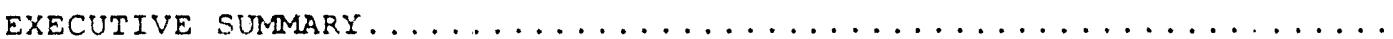

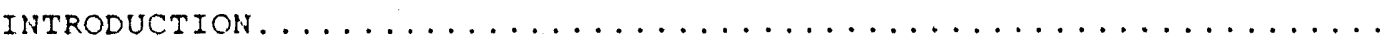

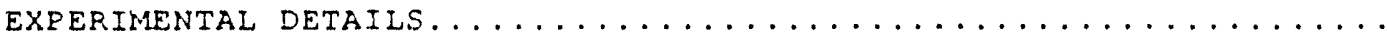

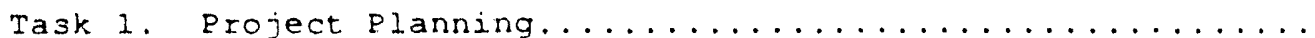

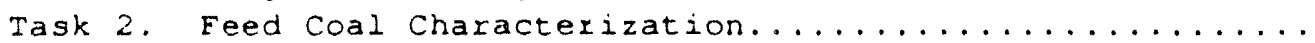
Subtask 2.1 Physical and Chemical Characteristics.....

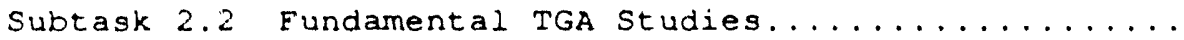

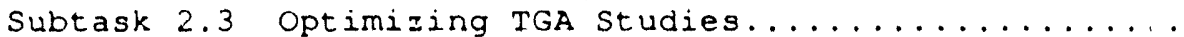

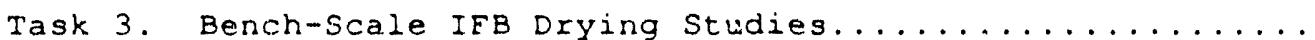
Subtagk 3.1 Minimum Fluidization Velocity..........

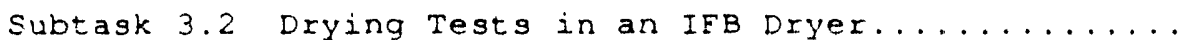

Task 4. Product Characterization and Testing.............

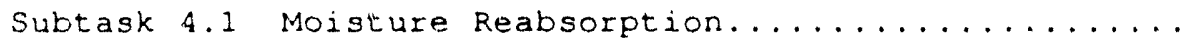

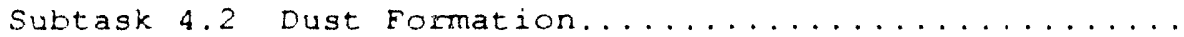

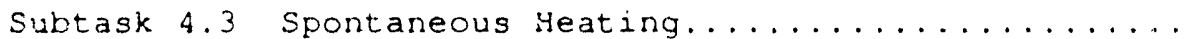

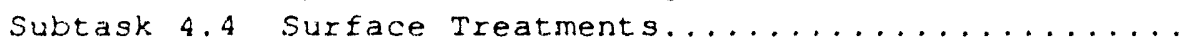

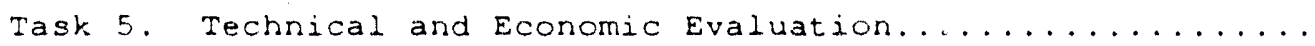

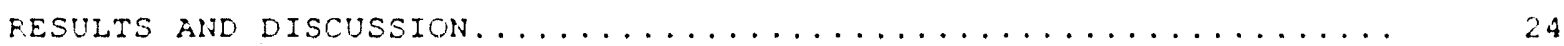

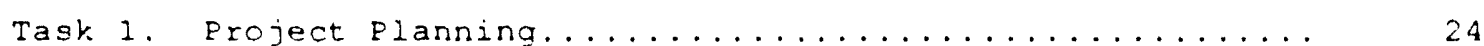

Task 2. Feed Coal Characterization.................. 25 Subtask 2.1 Fhysical and Chemical Characterization..... 25 Subtask 2.2 Fundamental TGA Studies.............. 29 Subtask 2.3 Optimizing TGA Studies............. 38

Task 3. Bench-Scale IFB Drying Studies.................. 50 Subtask 3.1 Minimum Fludization velocity........... 50 Subtask 3.2 Drying Tests in an IFB Dryer............ 68

Task 4. Testing and Characterization of Dried Coal........ 101 Subtask 4.1 Moisture Reabsorption............... 111 Subtask 4.2 Dust Formation................... 108 Subtask 4.3 spontaneous Heating............... 110 Surtask 4.4 Ehysical Eroperties............... 111

Task 5. Technical and Economic Eviluaticn............. ila Conceptui Commercial IfB Drying Elant Lesign........ 114

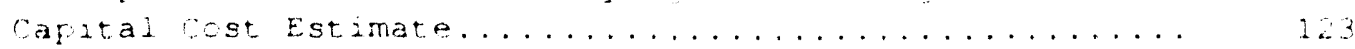

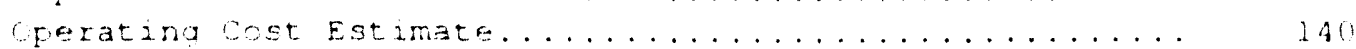

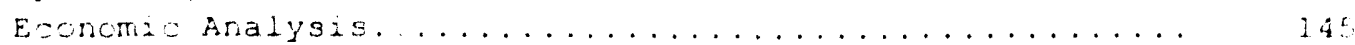

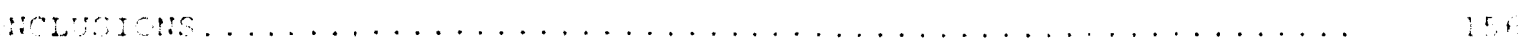

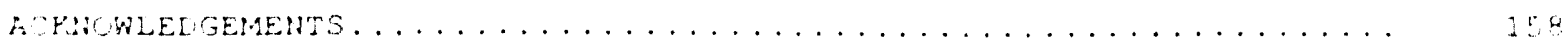

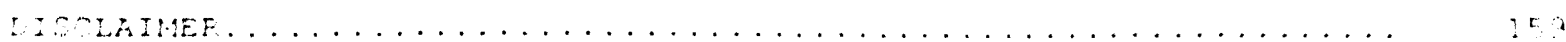

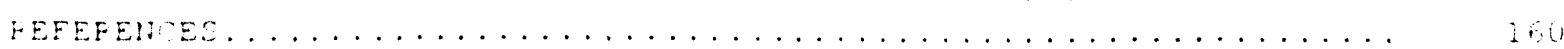

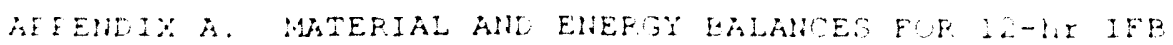

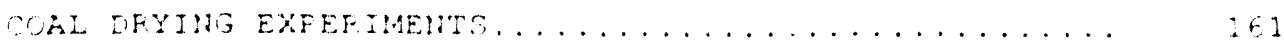

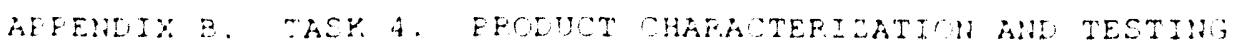

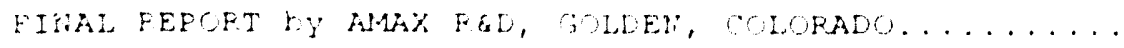


I. Project scope of work......................... 24

2. Results of Chemical Analyses of Feed Coals............. 27

3. Fundamental TGA Experimental Conditions and Recoveries...... 30

4. Optimizing TGA Experimental Material Balance Summary....... 39

5. Summary of IFB Cold Flow Test Results............... 62

6. Summary of Experimental Conditions for IFB Bench-Scale Drying Tests using Eagle Butte Coal................

7. Sumary of Experimental Conditions for IFB Bench-Scale Drying Tests using Usibelli Coal.................

8. Sumbary of Experimental. Balance Closures for IFB Bench-Scale Drying Tests using Eagle Butte Coal.................

9. Summary of Experimental Balance Closures for IFB Bench-Scale

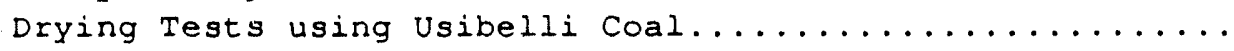

10. Summary of Experimental Yields for IFB Bench-Scale Drying Tests using Eagle Butte Coal.................

11. Summary of Lxperimental Yields for IFB Bench-Scale Drying Tests using Usibelli Coal..................

12. Summary of Experimental Elemental Balance Closures

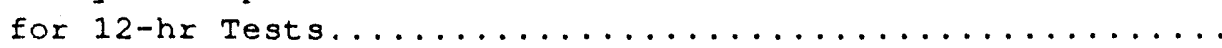

13. Summary of Experimental Energy Distributions for

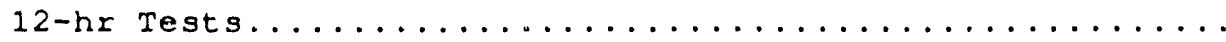

14 Minimum Reynolds Numbers for IFB Bench-Scale Drying Tests

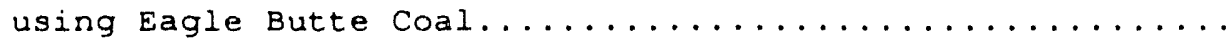

15. Minimum Reynolds Numbers for IFB Bench-Scale Drying Tests

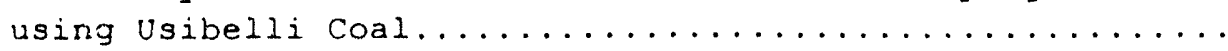

16. Maximum Reynolds Numbers for IFB Bench-Scale Drying Tests

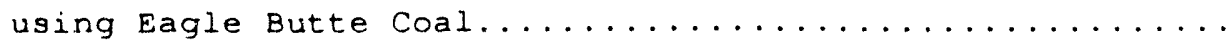

17. Maximum Reynolds Numbers for IFB Bench-Scale Drying Tests

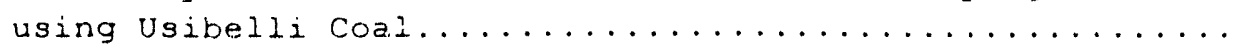

18. Solids Residence Times and Heating Rates for IFB Bech-Scale Drying Testa using Eagle Butte Coal................ 
19. Solids Residence Times and Heating Rates for IFB Bench-Scale Drying Tests using Usibelli Coal................

20. Reabsorption of Moisture by Eagle Butte Coal............

21. Reabsorption of Moisture by Usibelli Coal.............

22. Reabsorption of Moisture by Eagle Butte and Usibelli

Coals at Varied Relative Humidity.................

23. Moisture Reabsorption Characteristics of Oven-Dried

Eagle Butte and Usibelli Coals..................

24. Moisture Reabsorption Characteristics of Dried and Compressed Eagle Butte and Usibelli Coal Eriquettes......

25. Opacity Meter Measurements of Eagle Butte Coal Feeds

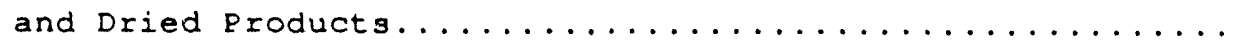

26. Opacity Meter Measurements of Usibelli Coal Feeds

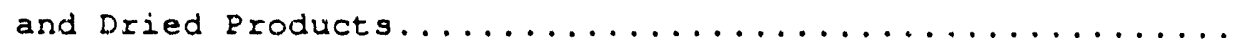

27. Effects of Drying Conditions on Self Heating Characteristics..........................

28. Eagle Butte and Usibelli Feed and Dried Coal Surface Area and Particle Densities................

29. Commercial Plant Feed Coal Composizion...............

30. Comercial Plant Thermal Efficiency................

31. Comnercial Plant Process Stream Conditions..............

3.2. Commercial Plant Descriptive Capital Equipment ist.......

33. Sources for Capital Equipment Cost Estimation............

34. Estimated Capital Equipment cost scale Factors...........

35. Estimated Capital Equipment Cost.s................

36. Sumary of Estimated Capital costs. ................ 


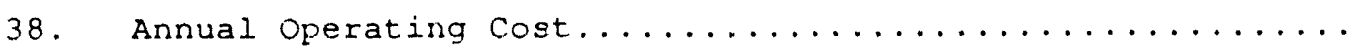

39. Commercial plant Electrical Useage Summary.............

40. Operating Labor Estimates for Commercial Plant.........

41. Annual Operating Cost Breakdown.................

42. Base Case Financial Assumptions ................

43. Base Case Discounted Cash Flow Sumnary................ 146

44. Briquette Selling Price Breakdown................. 147

45. Required Briquette Selling Price as a Function of

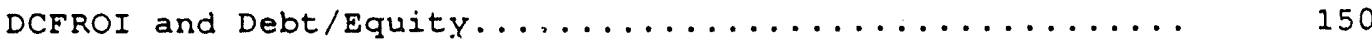

46. Required Briquette Selling Price as a Function of DCFROI and Annual Expenses................... 150

47. Required Briquette Selling Price as a Function of

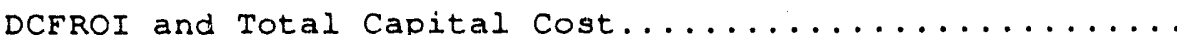


Page

1. Experimental Apparatus for MFV Determination............

2. Inclined Fluidized-Bed Cold Flow Model................. 12

3. Bench-Scale Coal Drying Unit.....................

4. Experimental Apparatus for Opacity Measurement............ 19

5. Schematic Diagram of the Self-Heating Characterization Apparatus............................... 21

6. Project schedule............................

7. Particle Size Distribution of the Crushed Feed Coals...... 28

8. Cumulative Screen Analysis of the Crushed Feed Coals...... 28

9. Normalized Weight Loss Profiles of Usibelli Coal from Fundamental TGA Tests................... 31

10. Normalized Weight Loss Profiles for Eagle Butte Coal

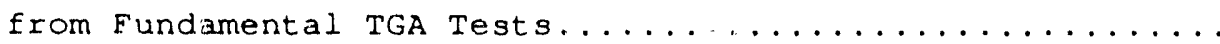

11. Rate of Weight Loss for Usibelli Coal............... 32

12. Rate of Weight Ioss for Eagle Butte Coal............. 32

13. Kinetic Fits to Pyrolysis Weight Loss Rates for

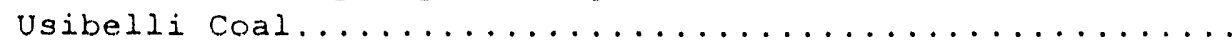

14. Kinetic Fits to Pyrolysis Weight Loss Rate for

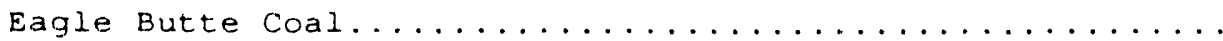

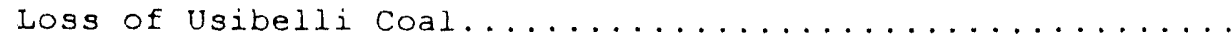

17. Kinetic Fits to water Weight Loss for Uaibelli Coal.......

18. Kinetic Fits to water Weight Loss for Eagle Butte coal..... 36

19. Activation Energy Distribution for water weight Loss

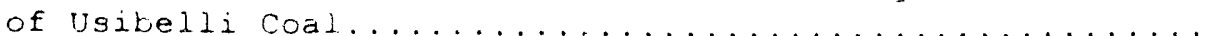

\section{Activation Energy Distribution for Pyrolysis weight}
16. Activation Energy Distribution for Pyrolysis weight Loss of Eagle Butte Coal.....................

\section{(1)}

\section{5} . . is 8

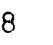

\section{2}


20. Activation Energy Distribution for Water Weight Loss

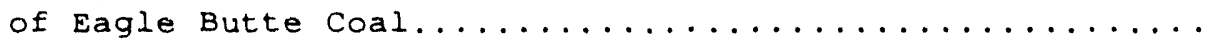

21. Rate of Weight Loss for Usibelli Coal

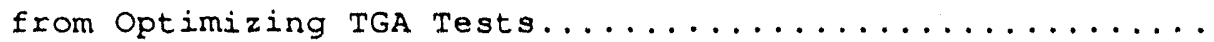

22. Rate of Weight Loss for Eagle Butte Coal

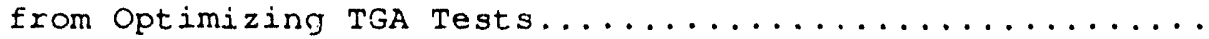

23. Pyrolysis Gas Evolution versus Temperature for Usibelli and Eagle Butte Coals.......................

24. Estimated Pyrolysis Conversion for Usibelli coal at

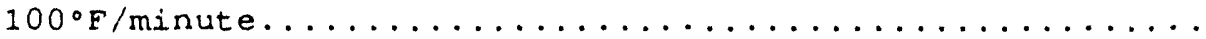

25. Estimated Rate of Pyrolysis Conversion for Usibelli

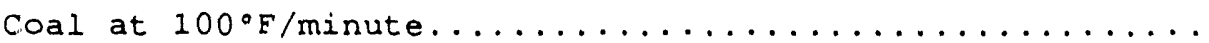

26. Estimated Pyrolysis Conversion for Eagle Butte Coal

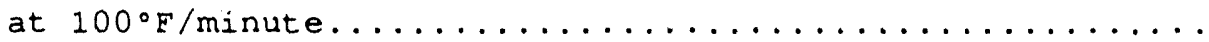

27. Estimated Rate of Pyrolysis Conversion for Eagle

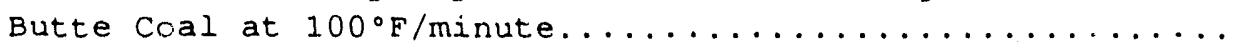

28. Estimated Cumulative Water Evolution for Usibelli Coal at

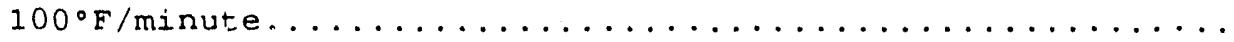

29. Estimated Rate of Water Evolution for Usibelli Coal

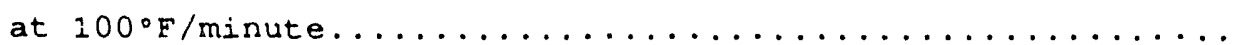

30. Estimated Cumulative Water Evolution for Eagle Butte Coal

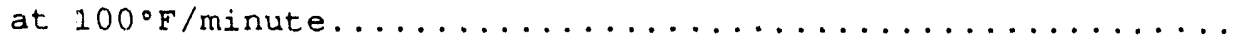

31. Estimated Rate of Water Evolution for Eagle Butte Coal

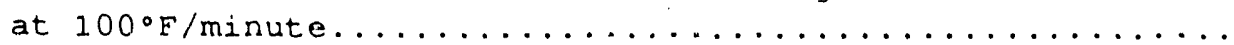

32. MFv Result for Eagle Butte Coal..................

33. MFv Result for Usibelli coal...................

34. Effect of IFB Reactor Slope on Solids Bed Geometry for -28 -mesh Eagle Butte Coal...................

35. Effect of IFB Reactor Slope on Solids Bed Geometry

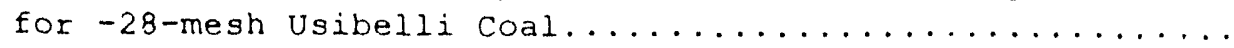


LIST OF FIGURES (continued)

\section{Figure}

page

36. Pressure Drop in Fluidized Solids.................

37. Average Solids Residence Time versus Solids Reynolds

Number for Eagle Butte Coal...................

38. Average Solids Residence Time versus Solids Reynolds

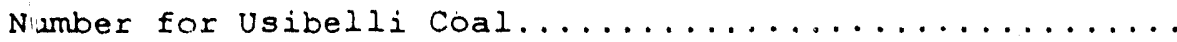

39. Averáge Solids Residence time versus Solids Reynolds Number

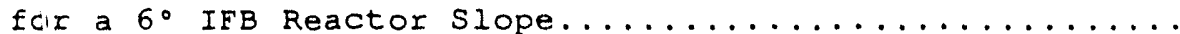

40. Average Solids Residence Time versus Solids Reynolds Number

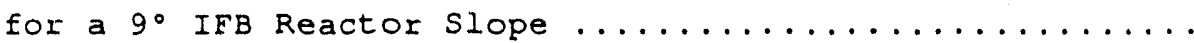

41. Averaçe Solids Residence Time versus Solids Reynolds Number for a $12^{\circ}$ IFB Reactor slope...................

42. Gas Yield versus Average IFB Drying Temperature

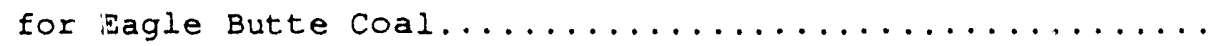

43. Gas Yield versus Average IFB Drying Temperature for Usibelii Coal..........................

44. Product Proximate Composition versus Average IFB Drying Temperature for Eagle Butte Coal..................

45. Product Proximate Composition versus Average IFB Drying Temperature for Usibelli Coal..................

46. Product (iarbon and Hydrogen Content versus Average IFB Drying Temperature for Eagle Butte Coal..............

47. Product Nitrogen and Sulfur Content versus Average IFB Drying Temperature for Eagle Butte Coal..............

48. Product Carbon and Hydrogen Content versus Average IFB Drying Temperature for Usibelli Coal...............

49. Prodult Nitrogen and Sulfur Content versus Average IFB Drying Temperature for Usibelil Coal................

50. Solids Entrainment versus Reynolds Number

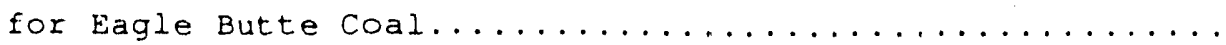

51. Solids Entrainment versus Reynolds Number

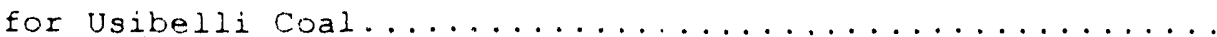


52. Moisture Reabsorption of Dried Cclals versus IFB

Drying Temperature for Eagle Butte and Usibelli Coals....

53. 3,000-TPD Commercial IFB Coal Drying plant.

Overall Material Balance....................

54. 3,000-TPD Commercial TFB Coal Drying Plant

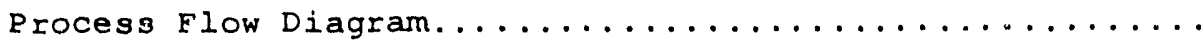

55. Installed Capital Equipment Cost Breakdown............

56. Annual Operating Cost Breakdown..................

57. Contributions of Major Capital Cost and Annual Expense Items to the Base Case Briquette Selling Price.............

58. Required Briquette Selling Price versus DCFROI for Debt/Equity of: $85 / 15,75 / 25,0 / 100 \ldots \ldots \ldots \ldots$

59. Required Briquette Selling Price versus DCFROI for a $\pm 20 \%$ Change in Annual Operating Expenses.........

60. Required Briquette Selling Price vergus DCFROI for a \pm 208 Change in Total Capital Costs............. 
The objective of this research project was to demonstrate a technically feasible and economically viable process for drying and stabilizing highmoisture subbituminous coal. Controlled thermal drying of coal fines was achieved using the inclined fluidized-bed drying and stabilization process developed by the Western Research Institute.

Eroject support was provided by the Pittsburch Energy Technology Center (PETC) of the U.S. Department of Energy (DOE). The research was conducted by the Western Research Institute in Laramie, Wyoming, and AMAX Research and Development center in Golden, Colorado. The project scope of work required completion of five tasks: (1) project planning, (2) characterization of two feed coals, (3) bench-scale inclined fluidized-bed drying studies, (4) product characterization and testing, and (5) technical and economic evaluation of the process.

High moisture subbituminous coals from AMAX Eagle Butte mine located in the powder River Basin of Wyoming and from Usibelli coal Mine, Inc. in Healy, Alaska were tested in a $10-1 \mathrm{~b} / \mathrm{hr}$ bench-scale inclined fluidized-bed. Experimental results show that the dried coal contains less than 1.58 moisture and has a heating value over 11,500 Btu/lb. The coal fines entrainment can be kejt below 15 wt of the feed. The equilibrium moisture of dried coal was less than 50\% of feed coal equilibrium moisture. 


\section{EXECUTIVE SUMMARY}

This research project was aimed at the development of a technically feasible and economically viable process using an inclined fluidized-bed (IFB) for drying and stabilizing high-moisture subbituminous coal. Project. support was provided by the Pittsburgh Energy Technology center (PETC) of the U.S. Department of Energy (DOE). The research was conducted by the Western Research Institute (WRI) and AMAX Research and Development (AMAX $R \& D)$

The main objective of this research was to develop a thermal process for drying fine coal that (1) reduces explosion potential, (2) uses the IFB with minimum elutriation, (3) produces a stable dry coal by preventing moisture reabsorption and autogenous heating, (4) reduces fugitive dust emissions, and (5) is technically and economically feasible.

The two feed coals selected for this research were from AMAX Coal. Company's Eagle Butte mine located in Campbell County, Wyoming, and from Usibelli Coal Mine, Inc.'s Eoker Flats mine located near Healey, Alaska. The feed coals were crushed to minus $590 \mu \mathrm{m}$ (28 mesh) to produce an average particle diameter of $70 \mu \mathrm{m}$ for the Eagle Butte coal and 80 m for the Usibelii coal as determined by wet screen analysis. Both the feed coals are high-moisture subbituminous coals with moisture contents of $29 \%$ and 228 (as received basis) for the Eagle Butte and Usibelli coals, respectively. Coincidentally, both the Eagle Butte and Usibelil coals used in tests have a heating value of 8,470 Btu/lb. 
T.FB reactor slopes of $3,6,9,12$, and 15 degrees were investigated for each feed coal. The average IFB dryer temperature of the experiments ranged from approximately 177 to $399^{\circ} \mathrm{C}\left(350\right.$ to $\left.750^{\circ} \mathrm{F}\right)$, and the carbon dioxide fluidizing gas velocity ranged from 1 to $6 \mathrm{ft} / \mathrm{min}$. The solids heating rate in the experiments varied from approximately 33 to $139^{\circ} \mathrm{C} / \mathrm{min}$ $\left(60\right.$ to $\left.250^{\circ} \mathrm{F} / \mathrm{min}\right)$, and solids residence times varied from 5 to $13 \mathrm{~min}$. In all of the experimonts, the dried coal product contained less than $1.5 \%$ moisture as determined by proximate analysis. As a result of drying and partial decarboxylation, the heating values of the coals were increased from $8,470 \mathrm{Btu} / \mathrm{Ib}$ to a range of 11,800 to $12,600 \mathrm{Btu} / \mathrm{lb}$ for Eagle Butte coal and to a range of 10,400 to 11,500 Btu/lb for Usibelli coal.

Solids entrainment from the IFB dryer correlates with the Reynolds number depicting fluid flow in the disengagement zone in the dryer. If the Reynolds number is maintained below 90 , entrainment from the IFB dryer is less than $15 \%$ of the Eagle Butte feed coal and is less than $10 \%$ of the Usibelli feed coal. Both the composition of dried coal and the amount of gas produced from the coal correlate with the average dryer temperature.

Product characterizations demonstrate that the IFB drying process can successfully produce dried coals containing less than one weight percent moisture. The equilibrium moisture of the dried coals was significantly reduced during the process to levels less than one-half that of the feed coals. Equilibrium moisture contents of these dried coals are significantly less than those produced from the same coals dried conventionally at lower tempratures in air. Reabsorption of moisture was well below 10 wt $\&$ when the coal samples were subjected to humidity conditions typical of those in 
many parts of the uniced states. The level of mristure reabsorption decreased as a function of increasing IFB drying temperature and was not a function of coll type. Brique'. .es prepared from the dried coals exhibited Lower amounts of moisture reabsorption than the diried coals from which they were prepared.

,

The dried coals contained very low fugitive dust compared to the feed coals. Spontareous heating characteristics of the dried coals and feed coals show that the died coals are more susceptible to spon:aneous heating than the feed coals. Increasing the IFB drying temperature increases the susceptibility of the dried coal to spontaneous heating.

The results of a preliminary economic analysis of a 3,000-ton/day coal drying and briquetting plant show that the selling price of the briquettes will need to be $\$ 19.35 /$ ton $(\$ 0.81 /$ MMBtu) to obtain a 15 rate of return on investment after taxes for the base case. The base case parameters for the analysis were: a $90 \%$ plant load factor; a debt-to-equity ratio of $75 / 25$; 108 bond interest; 20-year tax, bond, and plant life; straight line depreciation, zero inflation; and a coal cost of $\$ 4.25 /$ ton. Detailed economic analysis of the base case indicated that the installed capital costs, coal mining costs, and plant labor costs are the major contributors to the base case selling price. The total capital requirements are in the range of $\$ 29.55$ million to $\$ 26.45 \mathrm{million}$, and the estimated annual operating expenses are $\$ 8.40 \mathrm{million}$ including depreciation.

\footnotetext{
in sumary this research demonstrates that:
} 
1. The explosion potential can be minimized by operation of the process at a sightly positive pressure and by using carbon dionide produced from decarboxylation of the coal as drying media.

2. Elutriation from the inclined fluidized-bed can be controlled to less than 15 wt of the coal feed.

3. The inclined fluidizeci-bed process produces a dried coal with less than 1. wt moisture. The equibrium moisture af dried coal is less $50 \%$ of feed coal equilibrium moisture. However, the dried coal is more susceptible to spontaneous heating than the feed coal.

4. The fugitive dust emissions from the dried coal ar' much less than from the feed coal.

5. The wrI'e rFe coal dxying process has been proven technically feasible at the 10-1b/hr bench scale, and no significant operating or mainterance problems cocurred during experimentation at this scale. Freliminary economic projections for a 3,00o-ton/day commercial scale operation eugaest that the process should be economically feasible.

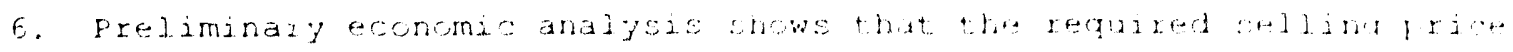

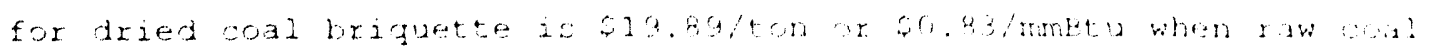

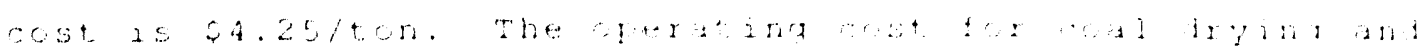

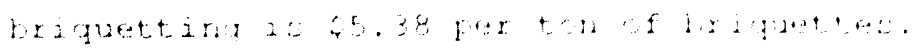


7. The process economics is sensitive to the foliowing items in decreasing order of significance:

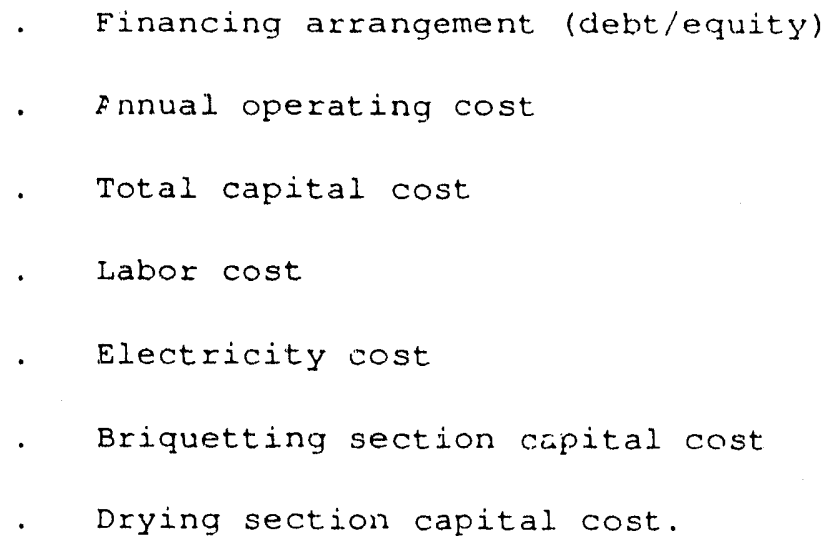

Future development of the IFB drying process should be conducted to:

1. Scale up reactor throughput

2. Scale up the particle size of the feed

3. Further stabilize the dried coal 


\section{INTRODUCTION}

During the $1950 \mathrm{~s}$ and $1960 \mathrm{~s}$, there was a trend toward increased tonnages of dry coal being sold in the united states. However, the advent of stringent emissions standards increased the cost of drying, and consequently, this trend was reversed in the $1970 \mathrm{~s}$.

Other trends have also become apparent in the coal mining industry. Mechanization of mining and beneficiation of coal increased the production of coal fines. Also, increased use in the central Inited states of lowsulfur and high-moisture subbituminous coals found in the western United states has revived interest in coal drying to reduce the cost of transporting the western coals to distant markets. Further, significant new potential markets for western coal have developed in the Pacific Rim nations. However, a reduction in coal transportation costs, such as that obtained by drying the coal, is needed to develop these potential markets.

Drying large tonnages of coal, particularly fines, has not been without problems. The use of air as a drying medium resulted in explosions in dryers; fine coal particles are more sumeptible to explosions than larger coal particles. Also, the ability to contrul elutriation from coal dryers has been difficult, and problems controlling elutriation have resulted in problems meeting particulate emissions standards. Further, dried coals must frequently be treated with oil before shipment to reduce reabsorption of moisture during transportalion and storare. Oil treatment is e:pensive, and its effect on reducing moisture reabsortion is limited. 
In this research, the controlled thermal drying of coal fines was achieved using an inclined fluidized-bed process developed by the Western Research Institute. This process was designed to address the problems associated with drying fine ccal. These problems include moisture reabsorption, dust formation, and spontaneous heating. Stabilization of dried coal is achieved by producing and conserving coal tars within -ne particles to reduce their active surface areas. Additional stabilization of dried coal is provided through the use of carbon dioxide as a cooling medium.

The main objective of the research was to develop a thermal process for drying fine coal that (1) reduces explosion potential, (2) uses a fluidized bed with minimum elutriation, (3) produces a stable dry coal by preventing moisture reabsorption and autogenous heating, (4) reduces fugitive dust emissions, and (5) is technically and economically feasible.

This objective was addressed by developing a new process for drying fine coal that:

1. uses carbon dioxide as the drying and cooling media to avoid the potential explosion hazards created when air or mixtures of air and combustion flue gas is used

2. Lises an inclined fluidized-bed reactor operating near the minimim fluidization velocity to provide excellent gas-solid contact while minimizing elutriation from the dryer 
3. reduces m-isture reabsorption and spontaneous heating by rapidly heating the coal particles to a temperature sufficient to mobilize tars in the coal and then rapidly quenching the particles with carbon dioride to seal off micropores and fill the micropores with carbon dioxide. 


\section{EXPERIMENTAL DETAILS}

The project scope of work required completion of five tasks: (1) project planning, (2) characterization of the two feed coals, (3) benchscale IFB drying studies, (4) testing and characterization of dried coal, and (5) technical and economic evaluation of the process. Details regarding the objectiveu of these tasks and the experimental procedures used to achieve the object ves are provided in this section.

\section{Task 1: Project Planning}

The objectives of this task were to coordinate the research effort; manage the project budget; provide contract deliverables on time and on budget; and to aid the contracting offices technical. representative (COTR) in evaluating performance, cost, problems, and work.

A project work plan covering the period of contract performance was submitted to DOE COTR in January 1989. This plan contained details on the activities required for successful completion of the project's scope of work. The detailed project work plan included the following: a work breakdown structure, a detailed project schedule, and a general description of the tests to be performed and the analytical techniques to be used.

\section{Task 2: Feed Coal Characterization}

Subtask 2.1--physical and chemical Charaterization 
The object.ive of this subtask was to determine the physical and chemical characteristics of the two feed coals before they were subjected to the drying process so that changes in the nature of the coal that occur during the drying process may be understood.

Proximate, ultimate, and heating value analyses were performed on samples of Eagle Butte (Wyoming) and Usibelii (Alaska) coals crushed to minus 28-mesh particle size. Samples of each crushed feed coal were subjected to dry and wet screen analyses and solid density and void volume determinations. All chemical and physical analyses were performed in duplicate.

All chemical analyses were performed using either ASTM or standard WRI methods. Proximate analyses were done using a Fisher Coal Analyzer model 490. Ultimate analyses were performed using a Perkin-Elmer Analyzer model 2400 for carbon, hydrogen, and nitrogen and a Fisher Sulfur Analyzer model 475 for sulfur. Oxygen content in the coal was determined by difference. The heating value of the coal was measured using an adiabatic parr bomb calorimeter.

Fine particles of the Eagle Butte coal clump together and form aggregates of a larger diameter. As a result, dry screening of this coal is inaccurate. In this project, wet screen analyses were performed on both coals. Screen sizes used were Tyler equivalent 35, 48, 65, 100, 150, and 200 mesh. 


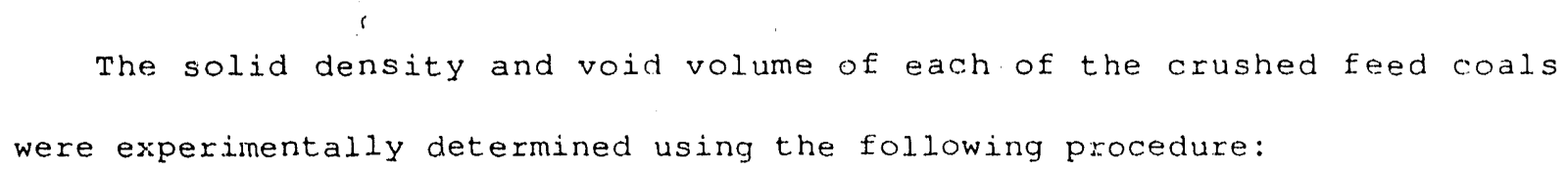

(1) An amount of crushed feed coal of known weight was added to a r" graduated cylinder, and the volume was measured.

(2) A measured volume of water was then added to the sample and allowed to completely penetrate the solids in the graduated cylinder. The volume of the coal and water mixture was measured after the water had adequate contact time to fill all void space in the solids.

(3) The bulk density of the crushed feed coal is the weight divided by the volume of the coal measured in step 1 . The void volume of the solids is the difference of the volume measured in step 1 plus the volume of water added in step 2 minus the volume of the mixture measured in step 2. The density of the solids is the bulk density divided by 1 minus the fraction void volume.

Subtask 2.2--Fundamental TGA Studies

The objective of the fundamental TGA tests was to determine the relative quantities and sequence of evolution of water and gases from the Wyoming and Alaskan coals.

The fundamental TGA studies were done using a Dupont 990 whermal Analysis System with Model 951 Tremogravimetry and DSC cell base modules. 


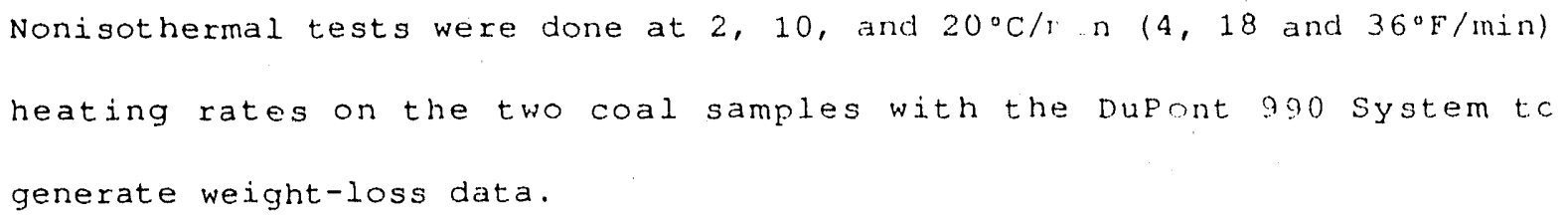

TGA data was analyzedd using kinetiss, a computer package designed to analyze data from TGAs with arbitrary thermal histories. This software was developed by Burnham et al (1987) of Lawrence Liverinore National Iraboratory and was used in the current study to extrapolate water-1oss and pyrolysis-loss profiles to a heating rate close to that in the inclined $\because$ Luidized-hed drier.

A key element of the Kinetics program is its capability to extrapolate data acquired on laboratory-scale instruments to arbitrary thermal histories. Weight loss profiles and rates an be generated for any heating rate of interest. This was accomplished for each of the two coal samples.

The estimared heating rate in the IFB drier is approximately $55.6{ }^{\circ} \mathrm{C} / \mathrm{min}\left(100^{\circ} \mathrm{F} / \mathrm{min}\right)$. Anticipated conversion and rate of conversion for drying and pyrolysis of the Usibelli and Eagle Butte coal in the IFB were estimated based on the kinetics program data for the appropriate residence times (or maximum temperatures) in the reactor.

Subtask 2.3--optimizing TGA studies

The objective of the optiniaing the ToA tests was to genexate pyrolysis gas evolution data as a function of temperature. These data are 
needed to relate the gas composition to the degiee of pyrolysis occurring in the bench-scale drying tests. Methane gas evolution is used as an indicator of carbon-carbon bond breaking in the coal structure. It is assumed that when carbon-carbon bond breaking occurs, the structure in the coal is significantly altered to allow the mobilization of coal liquids needed to seal the pcres. At optimal conditions bound water is removed and mobile nonvolatile products seal the coal pores to prevent moisture uptake.

Thermogravimetric analyses were done on the Cahn 131 system configured for evolved gas analysis. Each coal was heated from ambient temperature to $1000^{\circ} \mathrm{C}\left(1832^{\circ} \mathrm{F}\right)$ at a heating rate of approximately $10^{\circ} \mathrm{C} / \mathrm{min}\left(18^{\circ} \mathrm{F} / \mathrm{min}\right)$. A dry ice-ethyl alcohol trap collected condensables while a multiplesample-loop gas chromatographic system analyzed product gases. The sample-locp system captured 46 product gas aliquots at predetermined reaction times for later analysis by the Hewlett-packard 5890 gas chromatograph. The gas chromatograph was calibrated for hydrogen, carbon monoxide, methane, carbon dioxide, ethene, ethane, propane, propene, isobutane, and normalbutane.

\section{Task 3: Bench-Scale IFB Drying Studies}

The objectives of this task were (1) to demonstrate the drying process on a bench scale, (2) to evaluate the IFB as a coal classifier, (3) to obtain product samples needed for characterization, and (4) to obtain process data needed to estimate the commercial economic and technical. potential of the process. 
The approach was to determine the minimum fluidization velocity for each of the two coals, to determine the behavior of the IFB solids bed under a variety of fluidizing conditions by conducting IFB cold-flow tests for each crushed feed coal, and to conduct IFB dryer tests. This task consisted of two subtasks directed toward obtaining data needed to develop the IFB drying process.

Subtask 3.1--Minimum Fluidization Velocities (MFV)

Two cold-flow tests were conducted using each crushed feed coal to determine the minimum fluidization velocity of the coal particle size range used. A vertical 4-inch-diameter bed equipped with a distributor plate, a model NAHL-5P Hastings flow meter, a model HS-L55 flow controller, and a differential pressure meter were used to measure tre minimum fluidization velocity (Figure 1). A 4-inch-thick solids bed of the crushed feed coal is placed in the reactor on a distributor screen located above the fluidizing-gas inlet at the bottom of the pipe. Fluidizing-gas flow is incrementally increased to a flow rate that results in complete fluidization of the solids bed. The fluidizing-gas flow is then incrementally decreased until the flow rate is 0 scfm. The pressure drop through the solids bed is measured at each flow increment using a manometer or differential pressure gauge. Pressure taps were located below and above the solids bed. 


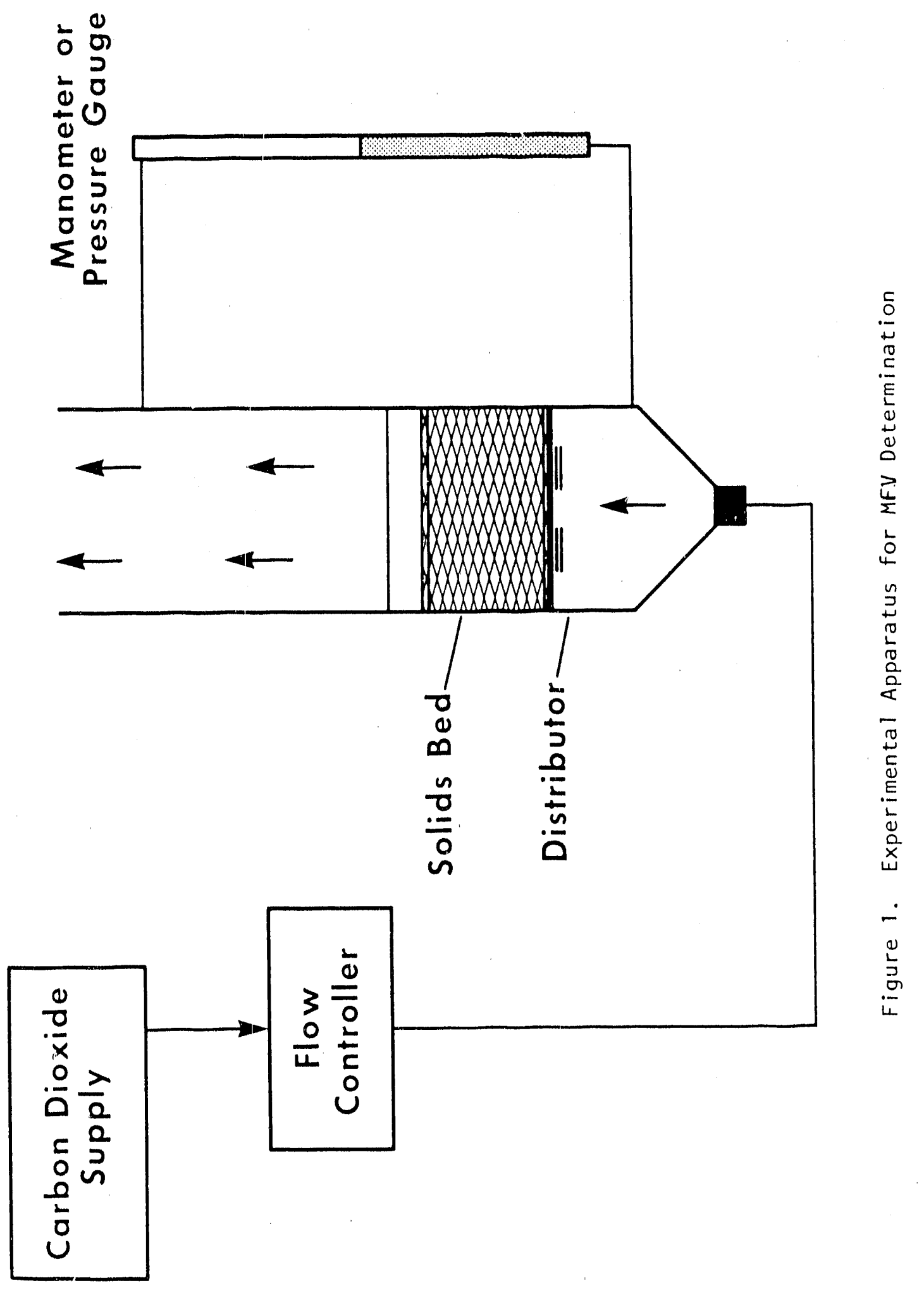


The pressure drop across the solids bed is plotted versus the fluidizing-gas velocity for both the increasing flow and decreasing flow conditions. These data are then qualitatıvely interpreted as outlined in the literature (Kunii and Levenspiel 1969). The first portion of the pressure c' sp versus fluidizing gas velocity curve is for the low-velocity conditions, and this portion of the curve increases in a near-linear fashion until the solids bed becomes at least partly fluidized. Just before the onset of fluidization, the pressure drop across the solids bed is maximum for both the increasing and decreasing flows.

Cold-flow tests were also conducted in a clear plastic model of the 10-1b/hr IFB dryer to examine the behavior of solids in the IFB under a variety of drying conditions. These tests proved useful to the operators - of the bench-scale unit. In addition, the horizontal transport of solids in the IFB was examined under a variety of fluidizing gas-to-solids ratios and different IFB reactor slopes. These determined the range of conditions that produced horizontal solids transport in the IFB and allowed bench-scale test conditions to be set. In addition, average solids residence times in the IFB cold-flow model were correlated to the flow conditions in the IFB reactor.

The IFB cold flow model is 61.5 inches long and 8 inches high (Figure 2). Crushed coal is fed to the reactor using a variable-speed screw feeder and lock hopper (not shown in diagram). Carbon dioxide fluidizing gas is supplied to the reactor in controlled amounts lising a thermal mass flow controller. Carbon dioxide exits the reactor by an atmospheric vent (not shown in diagram). 

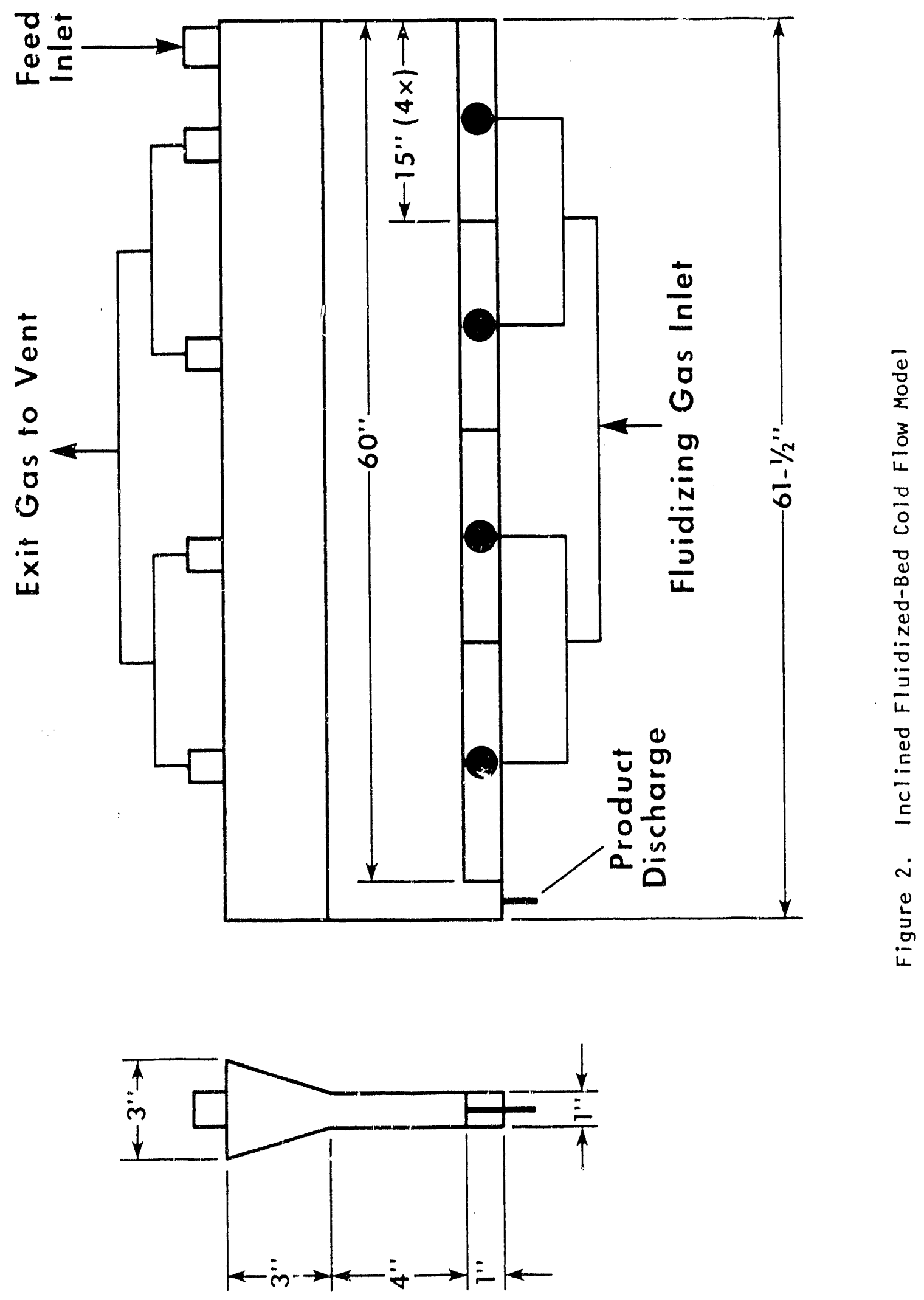
Numerous IFB cold flow tests lasting approximately 30 minutes were performed using a 10-lb/hr crushed coal feed rate, a variety of IFB coldflow reactor slopes ranging from 0 to 15 degrees, a variety of fluidizinggas flow rates ranging from 0.1 to $10 \mathrm{scfm}$, and both feed coals. The purpose of these tests was to examine the solids flow behavior in the IFB. Anuther series of IFB cold-flow experiments was performed to determine the relationship of the average solids residence time with the gas flow conditions in the IFB and the IFB reactor slope. These experiments required approximately one hour to complete, and 32 experiments were conducted; 16 using each feed coal. The experiments were conducted using a $10-1 b / h r$ coal feed rate, fluidizing-gas flow rates of $1.5,3.1,5.4$, and 7.8 scfm, and IFB slopes of $3,6,9$, and 12 degrees with Eagle Burte teed coal. and $6,9,12$, and 15 degrees with Usibelli feed coal.

Subtask 3.2--Drying Tests in the IFB Dryer

\footnotetext{
Drying tests were designed using data developed in the TGA and coldflow tests. The tests were conducted in series using -28 -mesh size coal and the feed rate of about 10-1b/hr at a fixed reactor slope. The fluidizing-gas (carbon dioxide) flow rate and IFB reactor temperature profile were varied to determine the optimum conditions for the drying temperature profile and coal residence time at a given IFB slope. Ihe reactor slope was then incrementally increased with each successive series of tests. The data from each series were used to evaluate the IfB reactor as a dryer and classifier. Data were collected to determine drying beh. "ior and particle entrainment from the IfB. Condicions resulting in
} 
effective coal drying with minimum fluidizing-gaj flowrate and minimum entrained solids production were desired.

Each series included four tests; the first three tests in each series ran at least 4 hours. The first test was a hot shakedown test using tine coal and gas flow rates and temperature profile suggested by the TGA tests, cold-flow tests, and previous bench-scale IFB tests. The second test was conducted after making any necessary adjustments to the equipment or operating conditions. The third test was designed to optimize the temperature profile and coal residence time. The fourth test was a $12-\mathrm{hr}$ demonstration lest using the best combination of conditions determined from the 4-hr tests. A total of 41 4-hr $(1.9$ using Eagle Butte feed coal and 22 using Usibeldi feed coal) and 8 12-hr (4 using each feed coal) bench-scale IFB drying tests were completed. IFB reactor slopes of 3 , 6 , 9, 12, and 15 degrees were investigated for each feed coal.

The experimental bench-scale IFB coal drying process equipment consis-s of two 5-ft-long IFB reactors in series separated by lockhopper valves that pneumatically isolate the two reactors while allowing for solids transfer from the first reactor to the second (Figure 3). The reactor provides for particle disengaging space above the bed. Effluent gas is withdrawn from multiple openings to avoid imparting significant 


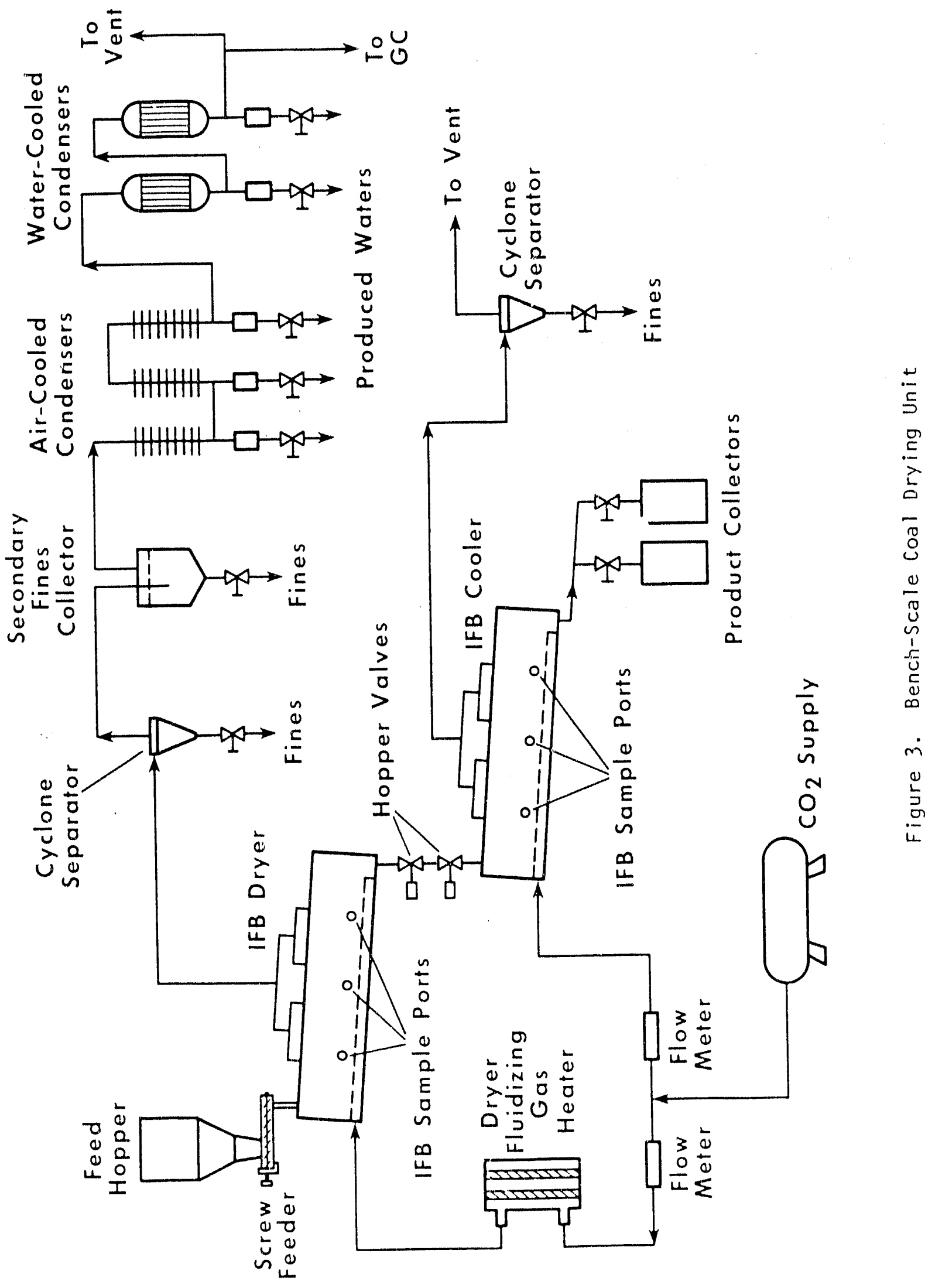


horizontal velocity to gas in the disengaging space. Effluent gas piping is arranged such that gas from all outlets flows the same distance and through the same number of tuins to balance flow from each withdrawal point. Heaters are placed to give four zones of independent temperature control. Bed thermocouples, gas sample points, and solid sample points are located such that complete sets of samples at known temperatures can be taken from the bed.

Controlled amounts of $\mathrm{CO}_{2}$ fluidizing gas are introduced into each of the IFB reactors. In the first reactor (IFB coal dryer) the $\mathrm{CO}_{2}$ is heated prior to introduction into the dryer. This hot $\mathrm{CO}_{2}$ supplies the process heat required for drying the coal. The coal is fed to the dryer from a sealed hopper using a variable-speed screw conveyor. Fine coal particles entrained in the fluidizing gas are collected in a cyclone separator and in a settling chamber (secondary fines collector). The exit gas from the settling chamber flows into a series of three air-cooled and two watercooled condensers to remove water from the gas. A small amount of the dry solids-free gas is sampled and analyzed using a gas chromatograph (GC). The remainder of this gas is vented to atmosphere.

The fluidizing gas $\left(\mathrm{CO}_{2}\right)$ introduced into the second reactor (IFB cooler) is at ambient temperature. It is used to cool the dried coal that exits the IFB dryer. Entrained solids in the exit gas are collected in a cyclone separator prior to venting the gas to atmosphere. The cooled dry coal is collected as product after it exits the IFB cooler. 


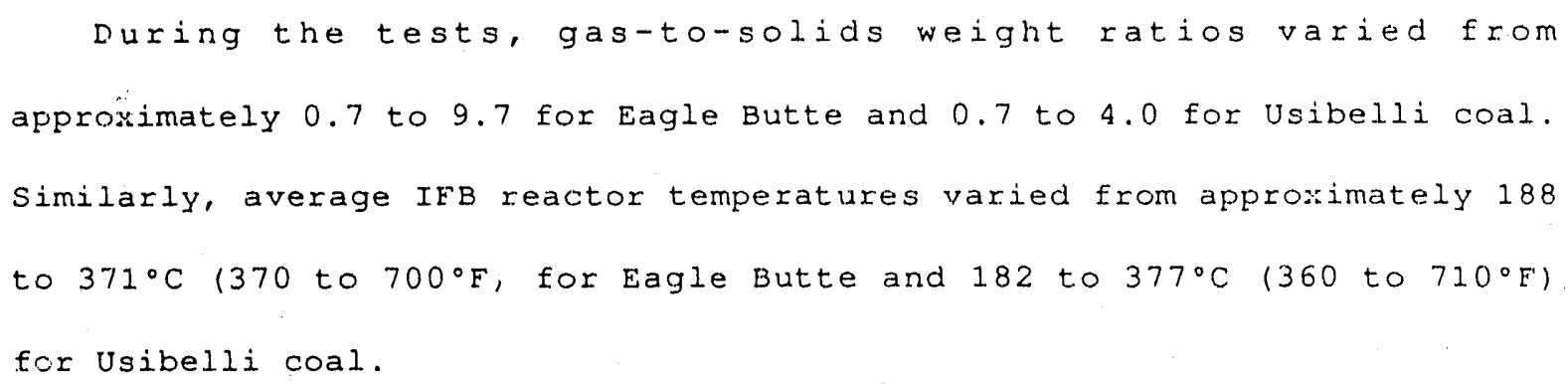

\section{Task 4.0 Testing and Characterization of Dried Coal}

This task consists of four subtasks with the objective of characterizing the products of the drying process. Characterization was necessary to determine the marketability and to complete the economic study. The products of the 12-hr drying tests and the feed coals were analyzed for moisture reabsorption, dustiness, and potential for spontaneous combustion.

Subtask 4.1--Moisture Reabsorption

The moisture reabsorption was measured in a controlled environment chamber (Associated Environmental systems Model BHK-4103) set to operate under high-humidity conditions. Coal samples were introduced into clean, desiccated, tared glass weighing dishes that were fitted with ground glass covers, which prevented loss or introduction of moisture. The coal samples were weighed in the covered dishes and placed into the controlled environment chamber. After removing the covers, the coal samples were exposed to high humidity until equilibrium was reached. The samples were imm liately covered when they were removed from the environmental ohamber and weighed after they reached room temperature. The amount of moisture 
increase was then determined. This technique was used to determine the moisture reabsorption characteristics of the feed and product samples. The equilibrium moisture contents of the entrained coal fines were estimated based on the average of the feed and product values.

Subtask 4.2--Dust Formation

The dustiness of the samples was determined using the opacity meter shown in Figure 4. This opacity neter was originally designed by Dow Chemical and is effective for comparing dust formation from various feed and product samples. The meter deterinines the amount of dust from the sample as a function of time by opacity measurement. The unit consists of a 4-inch-diameter vertical stainless steel pipe 30 inches long into which a measured amount of the sample is introduced. A helium-neon laser is the light source with a $632.8 \mathrm{~nm}$ wavelength. The laser beam traverses the diameter of the pipe at a location near the bottom of the pipe. A photo detecto: is used to measure the transmittance of the laser light as the dust settles. A strip chart recorder automatically registers the transmittance as a function of time. A greater amount of light transmission indicates a lower amount of dust formation (Juglic 1986 ). 


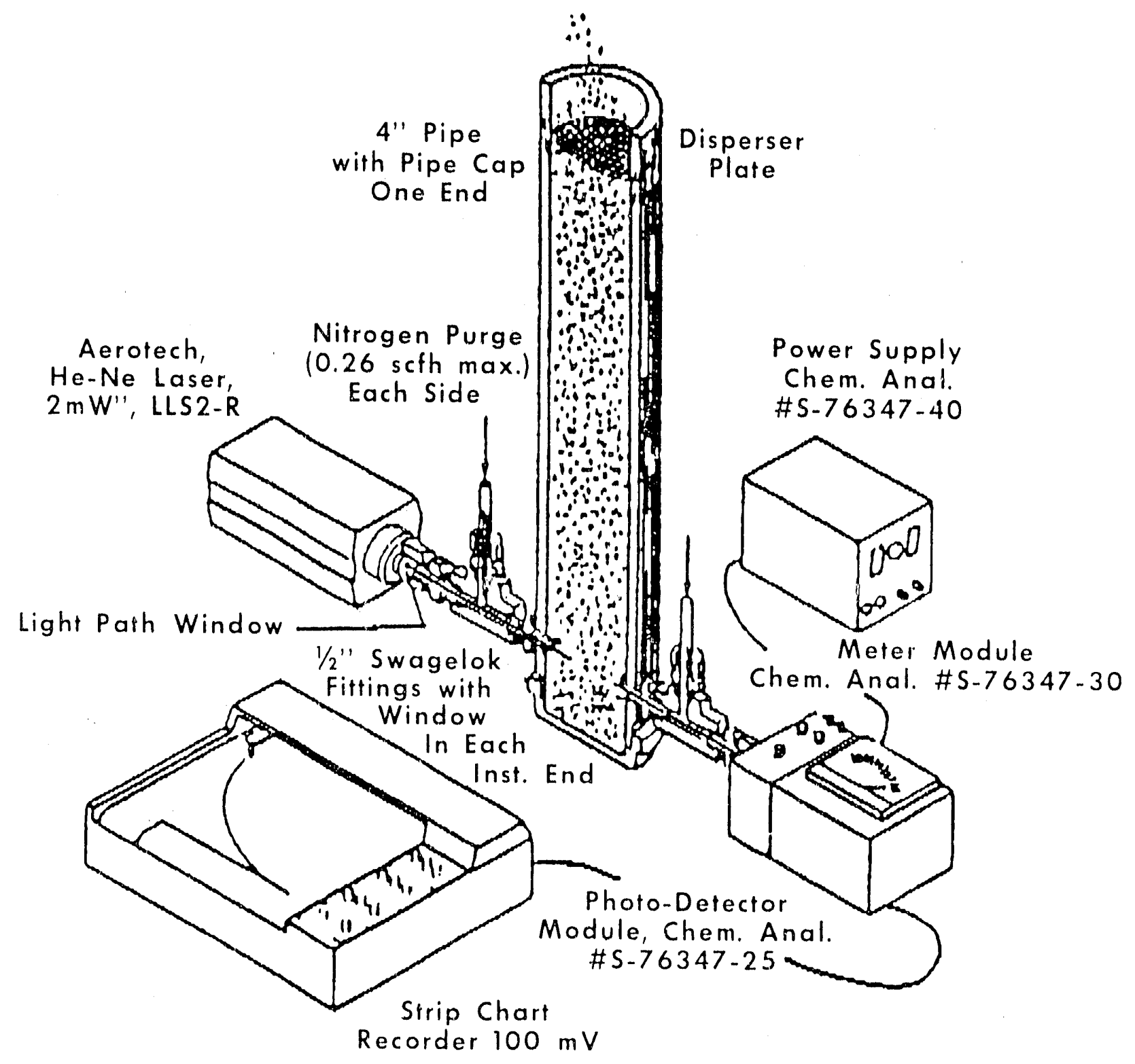

Figure 4. Experimental Apparatus for Opacity Measurement 
Subtask 4.3--Spontaneous Heating

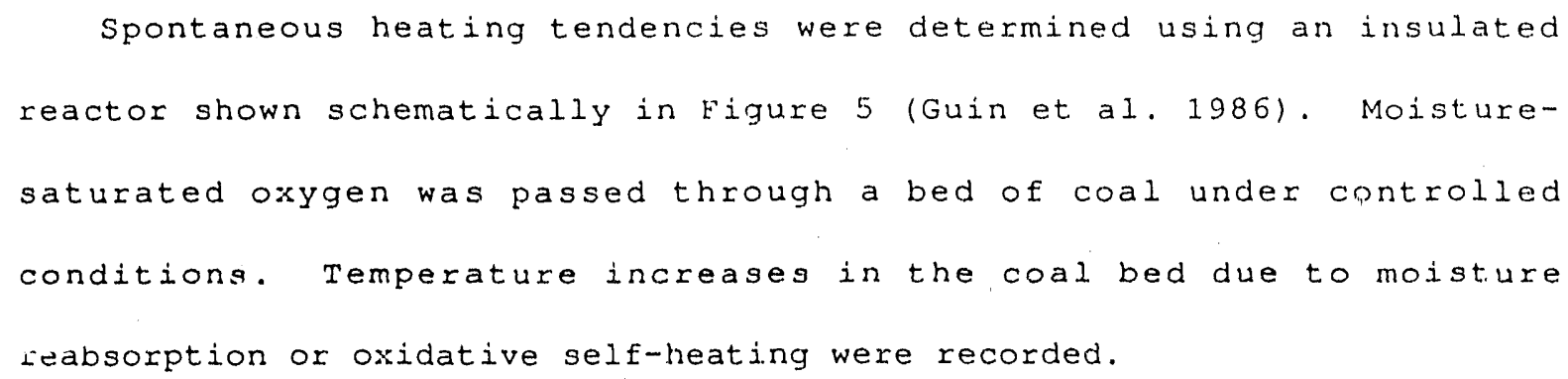

Spontaneous heating tests were conducted using the feed and selected dry coal products. Initial tests were performed to determine the sample size, starting temperature, and oxygen flow rates. All samples tested showed a strong initial temperature increase caused by the heat of absorption. Based on the initial tests, a starting temperature of $70^{\circ} \mathrm{C}$ $\left(158^{\circ} \mathrm{F}\right)$ was selected for most samples. Tests were conducted using 300 grams of coal loaded into the Dewar flask and an oxygen flow rate of 160 $\mathrm{cc} / \mathrm{min}$. 

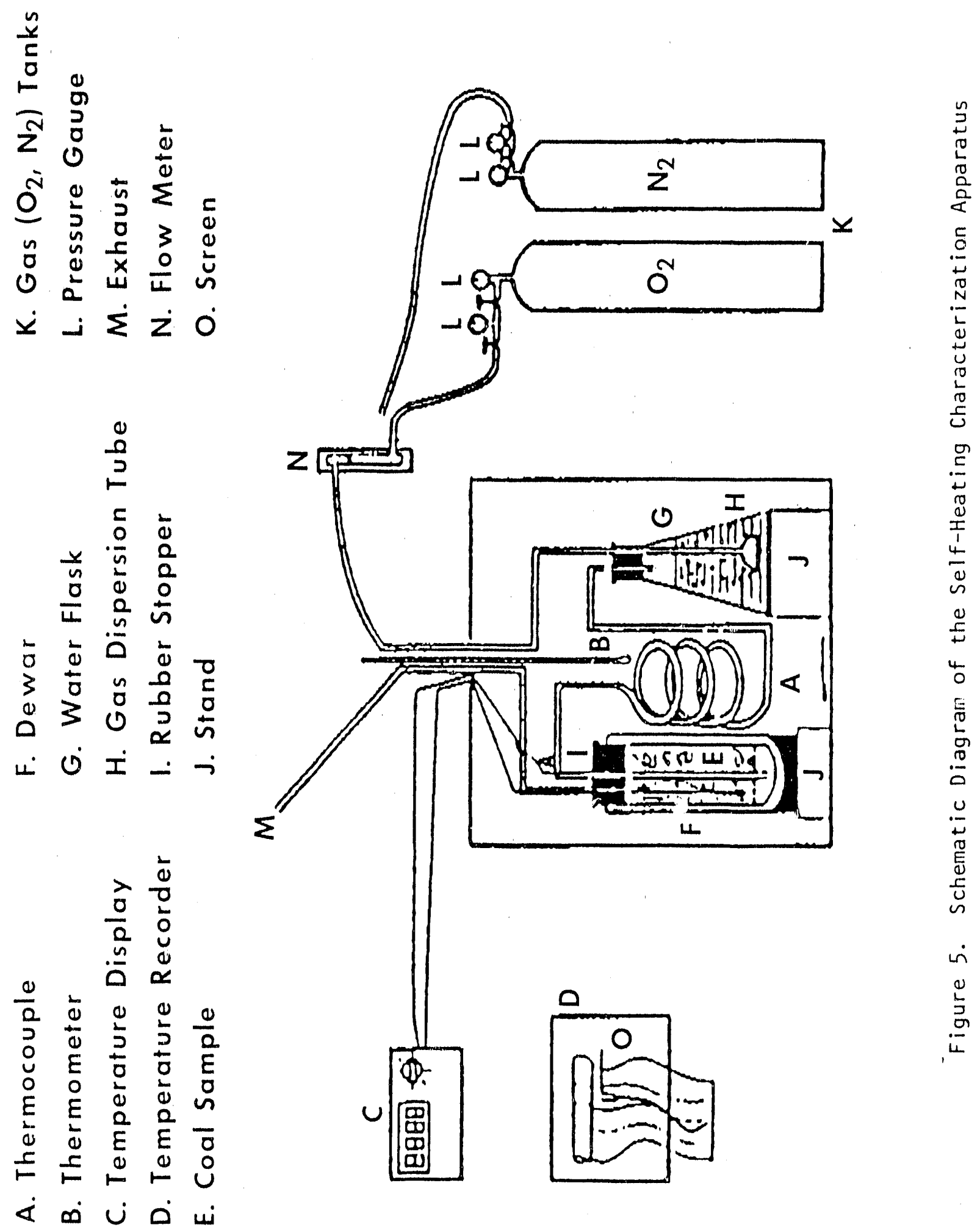
Subtask 4.4--Surface Treatments

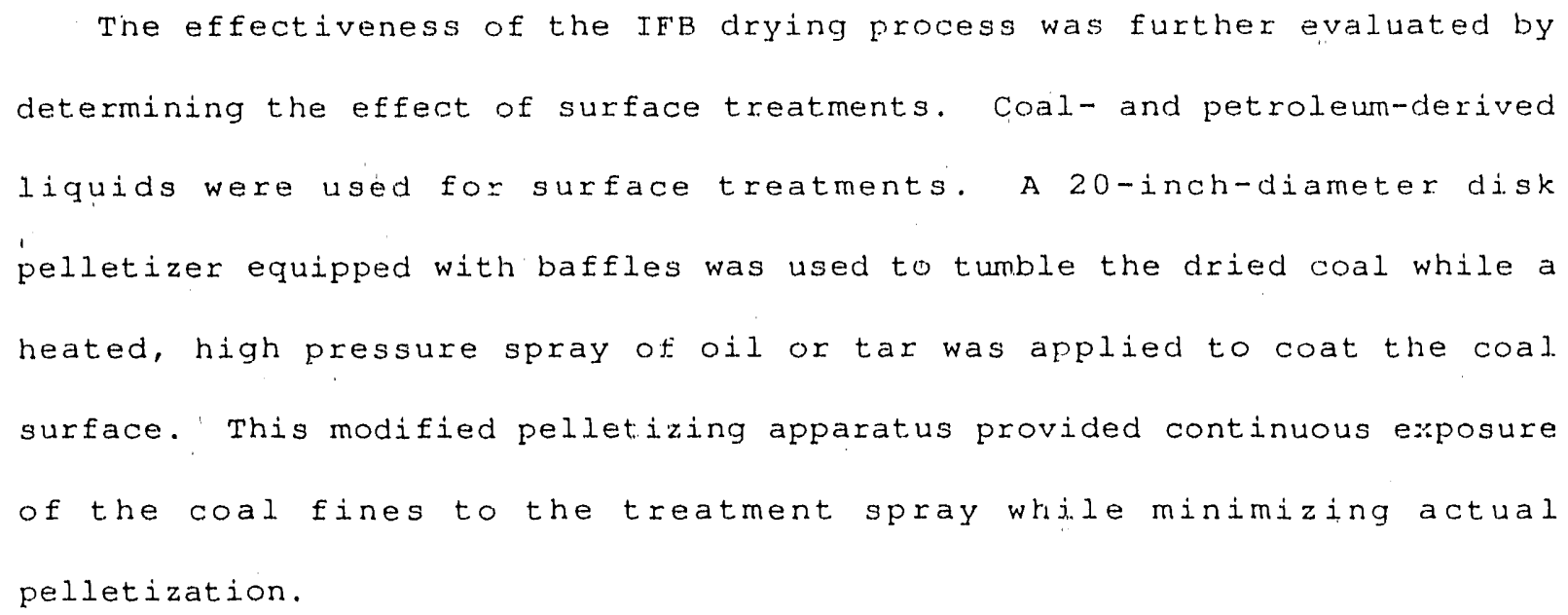

A Parr stainless steel autoclave was used as a pressure vessel from which the heated oil was sprayed. An inert gas was used to apply the pressure to the autoclave and a flexible, heat-traced line to deliver the fluid to a spray nozzle.

In addition, surface area and particle density determinations were performed on selected feed, pro'uct, and fine samples. particle densities were determined by displacement of kerosene. Standard BET method was used to measure the surface area of coal samples.

Task 5--Technical and Economic Evaluation

\footnotetext{
The objectives of this task are (1) to evaluate the commercial potential of the IFB drying process using information obtained in tasks 2, 3, nd 4 of this project, (2) to identify technical areas that require further process development for commercialization to occur, and (3) to
} 
evaluate the items to which the commercial economics of the process are most sensitive.

A preliminary process flow diagram was developed for a potential. commercial drying operation of Eagle Butte coal using the IfB process. Material and energy salances were developed based on the experimental data obtained from the 10-lb/hr IFB. The major equipment items necesgary for the operation were sized and priced using the process flow diagram and material and energy balances. Based on the installed equipment costs, total capital investment was estimated. Also annual operating costs were estimated for the commercial operation. The return on investment for such a venture was then determined. The economic sensitivity of the various parameters was investigated to identify the technical feasibility and strengths and weaknesses of the final process design. 


\section{RESULTS WNI DISCUSSION}

Task 1. Project Planning

The results of the project planning are briefly summarized in Table 1 , which outlines the tasks of the project. Figure 6 shows the project schedule.

Table 1. Project Scope of Work

$\begin{array}{ll}\text { Task } 1 & \text { Project Planning } \\ \text { Task } 2 & \text { Feed Coal Characterization } \\ & 2.1 \text { Physical and Chemical Characterization } \\ & 2.2 \text { Fundamental TGA Studies } \\ & 2.3 \text { Optimizing TGA Studies } \\ & \text { Bench-Scale IFB Drying Studies } \\ & 3.1 \text { Minimum Fluidization Velocity } \\ & 3.2 \text { IfB Drying Tests } \\ & \text { Testing and Characterization of Product } \\ & 4.1 \text { Moisture Reabsorption } \\ & 4.2 \text { Dust Formation } \\ & 4.3 \text { Spontareous Heating } \\ & 4.4 \text { Surface Treatment } \\ & \text { Technical and Economic Evaluation } \\ & \end{array}$


CONTRACT MONTH

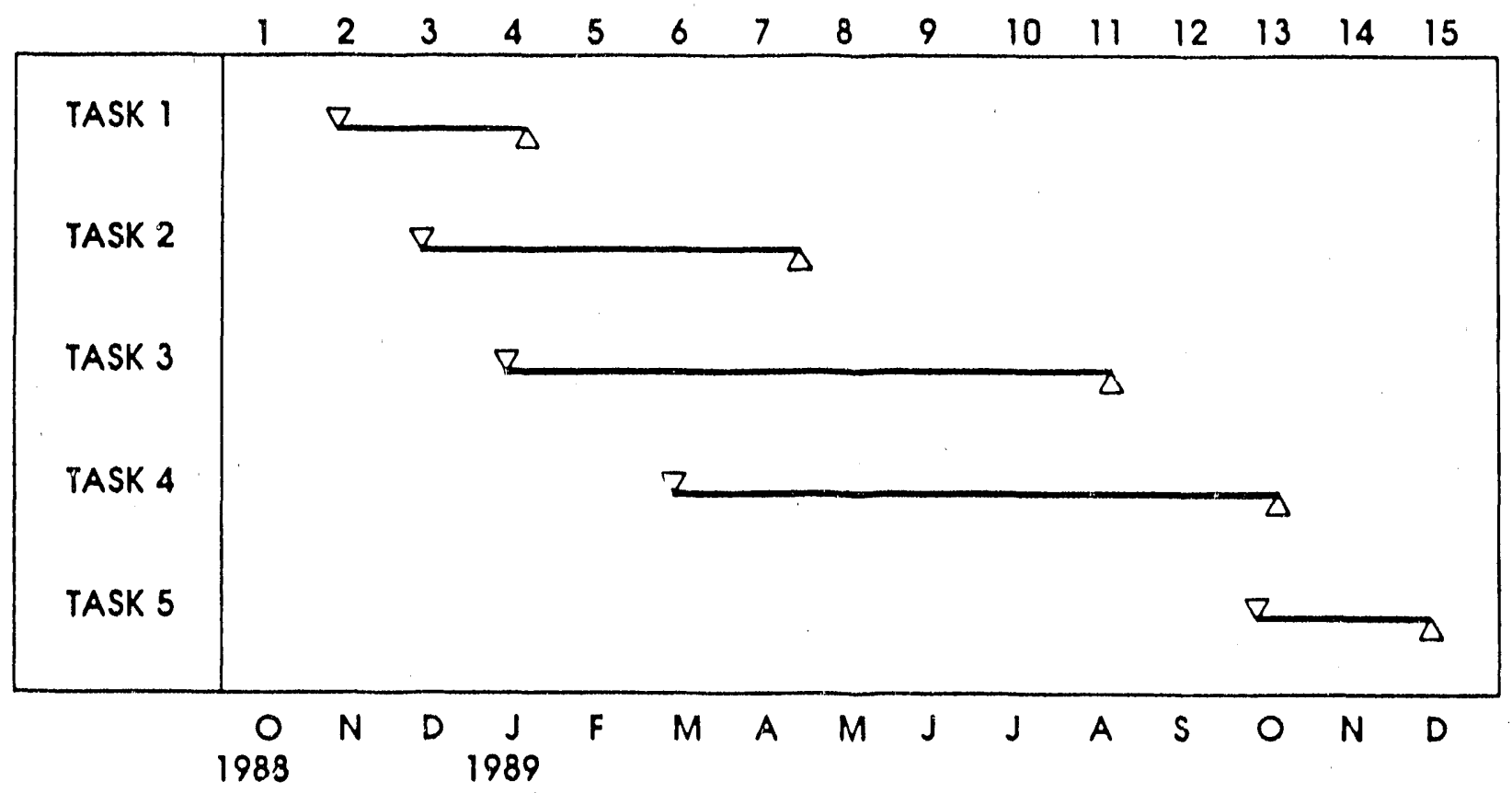

CALENDAR MONTH

Figure 6. Project Schedule

Task 2: Feed Coal Characterization

Subtask 2.1--physical and Chemical Characterization

Eigures 7 and 8 are graphical representations of the results of wet soreen analyses of the crushed Eagle Butte and Usibelli feed coals, respectively. The weighc fraction retained on each screen is displayed in the bar chart for the crushed feed coal samples (Figure 7). The cumulative percent retained as a function of particle size is also presented for the both feed coal samples in Figure 8 .

The wet screen analysis of the crushed feed coal samples indicate tre average particle diameter is approximately $70 \mu \mathrm{m}$ for the crushed Eagle Butte 


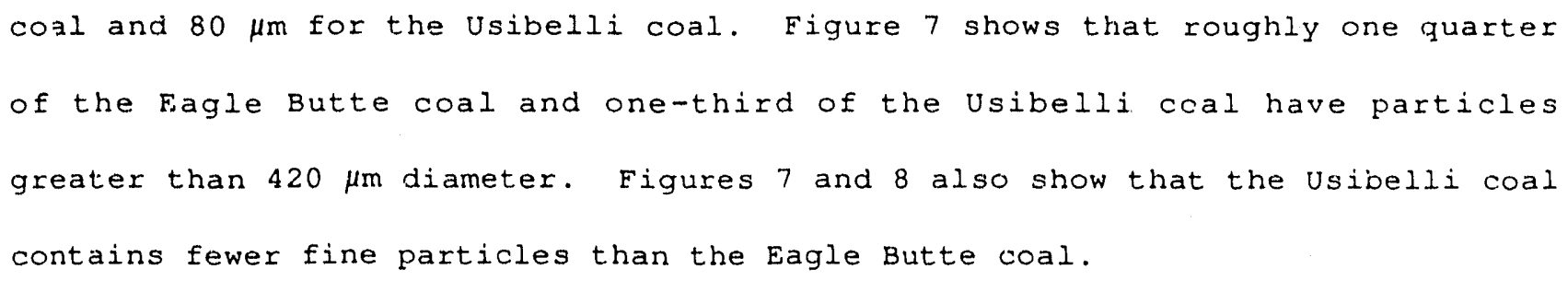

Proximate, ultimate, and heating value analyses were performed on samples of Eagle Butte and Usibelli coals crushed to $-590 \mu \mathrm{m}$. In addition, samples of each crushed feed coal were subjected to screen analyses and solid density and roid volume determinations. Both the chemical and physical analyses were performed in duplicate.

Results of the chemical analyses for proximate and ultimate composition and heating value of both feed coals are listed in Table 2 . 
Table 2. Results of Chemical Analyses of Feed Coals

\begin{tabular}{|c|c|c|}
\hline Analysis & Eagle Butte & Usibelli \\
\hline Proximate (wt \& as received) & & \\
\hline volatile Matter & 30.9 & 36.4 \\
\hline Fixed Carbon & 35.2 & 33.3 \\
\hline Ash & 4.7 & 8.3 \\
\hline Moisture & 29.2 & 22.0 \\
\hline Ultimate (wt $z$ on dry basis) & & \\
\hline Carbon & 67.4 & 61.5 \\
\hline Hydrogen & 5.1 & 5.2 \\
\hline Nitrogen & 0.9 & 0.9 \\
\hline Sulfur & 0.6 & 0.2 \\
\hline Oxygen & 19.4 & 21.6 \\
\hline Ash & 6.6 & 10.6 \\
\hline Heating Value, Btu/lb & 8,470 & 8,470 \\
\hline
\end{tabular}




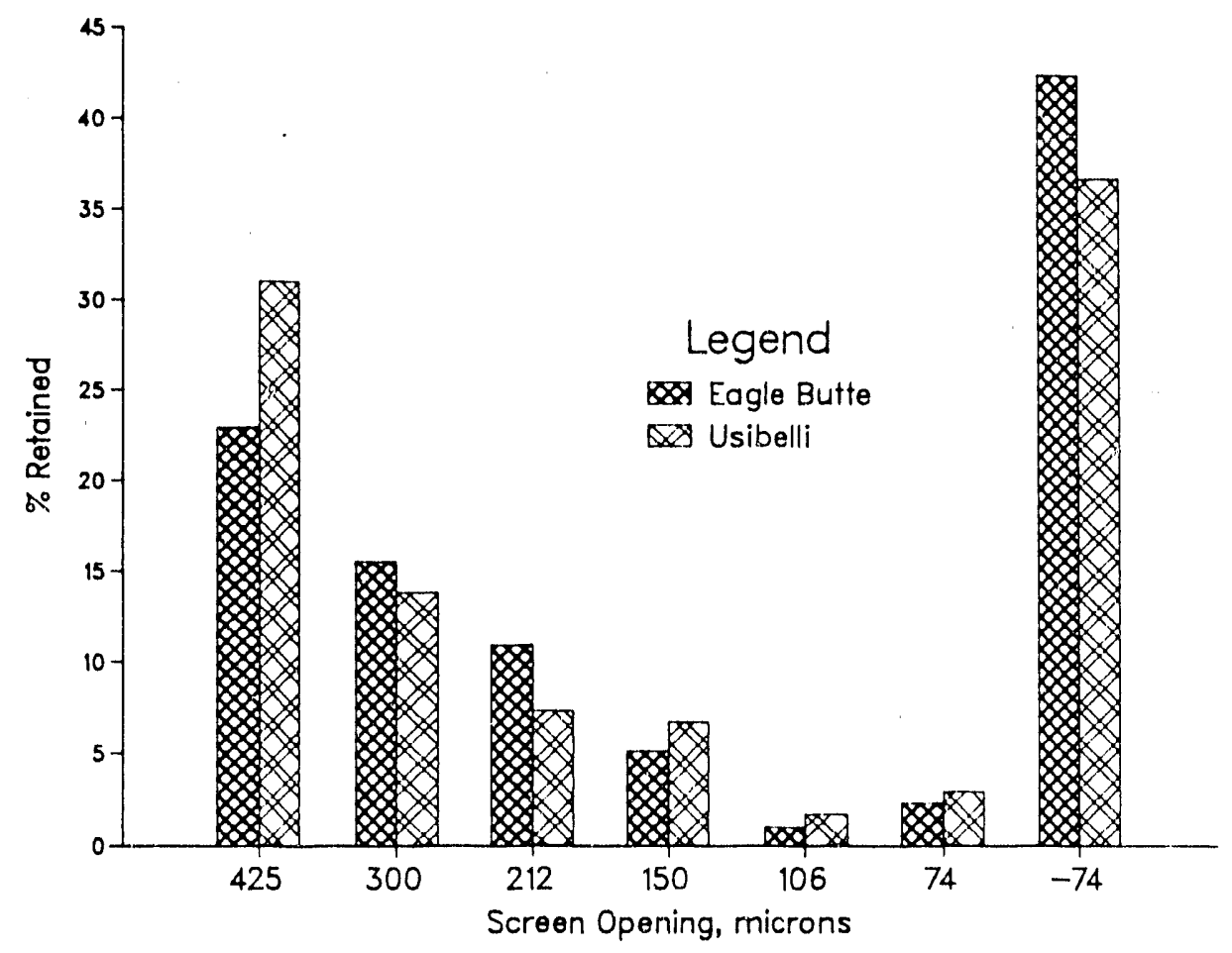

Figure 7. Particle Size Distribution of the Crushed Feed Coals

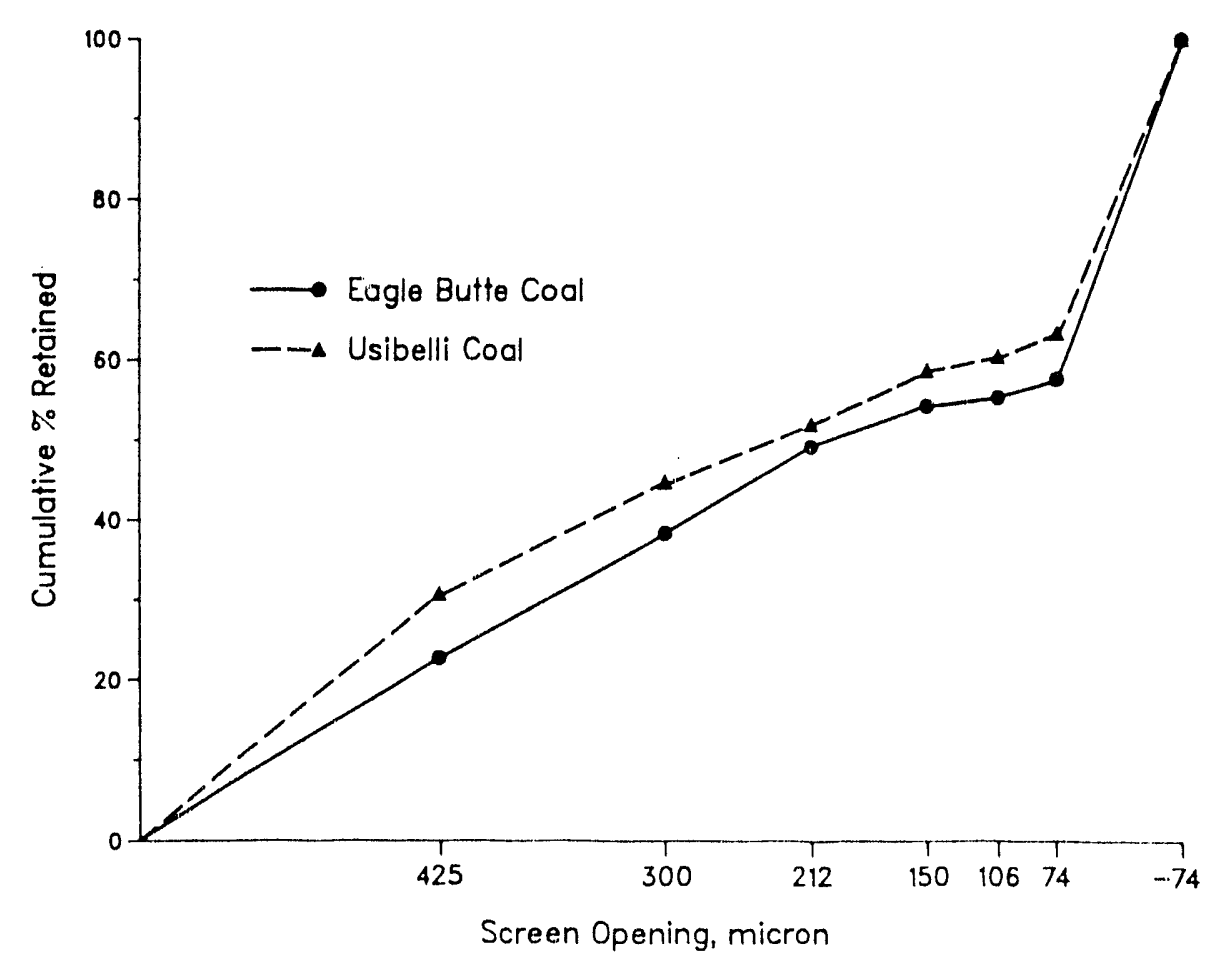

Figure 8. Cumulative Screen Analysis of the Crushed Feed Coals 


\section{Subtask 2.2 Fundamental TGA Studies}

Fundamental studies were done in the Dupont TGA system for data on weight loss to support the Kinetics modeling program.

TGA tests were performed at three heating rates: 2, 10 , and $20^{\circ} \mathrm{C} / \mathrm{min}$ (4, 18, and $36^{\circ} \mathrm{F} / \mathrm{min}$ ) on the two coal samples (Usibelii and Eagle Butte). Conditions for the experiments are summarized in Table 3 . The actual heating rate for each test was determined from a linear least-squares fit of the time and temperature data, thus, there are some minor heating rate differences in the table.

Normalized weight-loss profiles for the Usibelli and Eagle Butte coals are shown in Figures 9 and 10, respectively. The curves have been normalized at $200^{\circ} \mathrm{C}\left(392^{\circ} \mathrm{F}\right)$ where a clear plateau marks the transition between the end of free-water evolution and the start of pyrolytic devolatilization. The percent of sample weight lost for each test in the temperature rise to $200^{\circ} \mathrm{C}\left(392^{\circ} \mathrm{F}\right)$ is listed in Table 3 . Also shown, is the calculated moisture-free residue assuming all free water is lost at $200^{\circ} \mathrm{C}$ $\left(392^{\circ} \mathrm{F}\right)$. The average moisture-free char at $900^{\circ} \mathrm{C}\left(1,652^{\circ} \mathrm{F}\right)$ is $54.4 \pm 0.38$ for the Usibelli coal and $57.9 \pm 1.28$ for Eagle Butte coal, indicating reasonable consistency. 
Table 3. Fundamental TGA Experimental Conditions and Recoveries

\begin{tabular}{|c|c|c|c|c|c|c|}
\hline \multirow{2}{*}{ Run Number } & \multicolumn{3}{|c|}{ Usibel1i Coal } & \multicolumn{3}{|c|}{ Eagle Butte Coal } \\
\hline & $P-5$ & $\mathrm{P}-1$ & $P-3$ & $p-6$ & $P-2$ & $P-4$ \\
\hline \multicolumn{7}{|l|}{ Conditions } \\
\hline Heating Rate, $\mathrm{C}^{\circ} / \mathrm{min}$ & 4.49 & 8.92 & 18.1 & 4.47 & 8.97 & 18.12 \\
\hline Sweep Rate, sccm He & 100.0 & 100.0 & 100.0 & 100.0 & 100.0 & 100.0 \\
\hline Bar. $\mathrm{P} ., \mathrm{mm} \mathrm{Hg}$ & 585.4 & 584.1 & 587.7 & 585.1 & 585.5 & 584.9 \\
\hline Back Pressure, $\mathrm{mm} \mathrm{Hg}$ & 14.9 & 14.9 & 14.9 & 14.9 & 14.9 & 14.9 \\
\hline Ambient Temperature, $\mathrm{C}^{\circ}$ & 22.5 & 23.0 & 24.0 & 24.0 & 24.5 & 25.5 \\
\hline Sample Weight, ng & 34.97 & 45.15 & 40.00 & 46.41 & 42.26 & 32.88 \\
\hline \multicolumn{7}{|l|}{ Material Recovery, ( 8$)$} \\
\hline Trapped Liquids & 49.2 & 63.3 & 32.0 & 45.3 & 41.4 & 44.7 \\
\hline Water Loss $\left(200^{\circ} \mathrm{C}\right)$ & 22.2 & 18.7 & 19.8 & 26.9 & 21.2 & 26.0 \\
\hline Char $\left(\sim 900^{\circ} \mathrm{C}\right)$ & 42.3 & 44.0 & 43.9 & 43.3 & 44.8 & 42.6 \\
\hline Char (moisture free) & 54.4 & 54.1 & 54.7 & 59.2 & 56.9 & 57.6 \\
\hline
\end{tabular}

Differential rate of weight-loss profiles for the Usibelii and Eagle Butte coals show more dramatically the temperature separation for free-water loss and pyrolysis weight loss (Figures 11 and 12). At all heating rates examined, the two weight-loss regions are separated by at least $50^{\circ} \mathrm{C}\left(90^{\circ} \mathrm{F}\right)$ with the center of the separation at $200^{\circ} \mathrm{C}\left(392^{\circ} \mathrm{F}\right)$. 


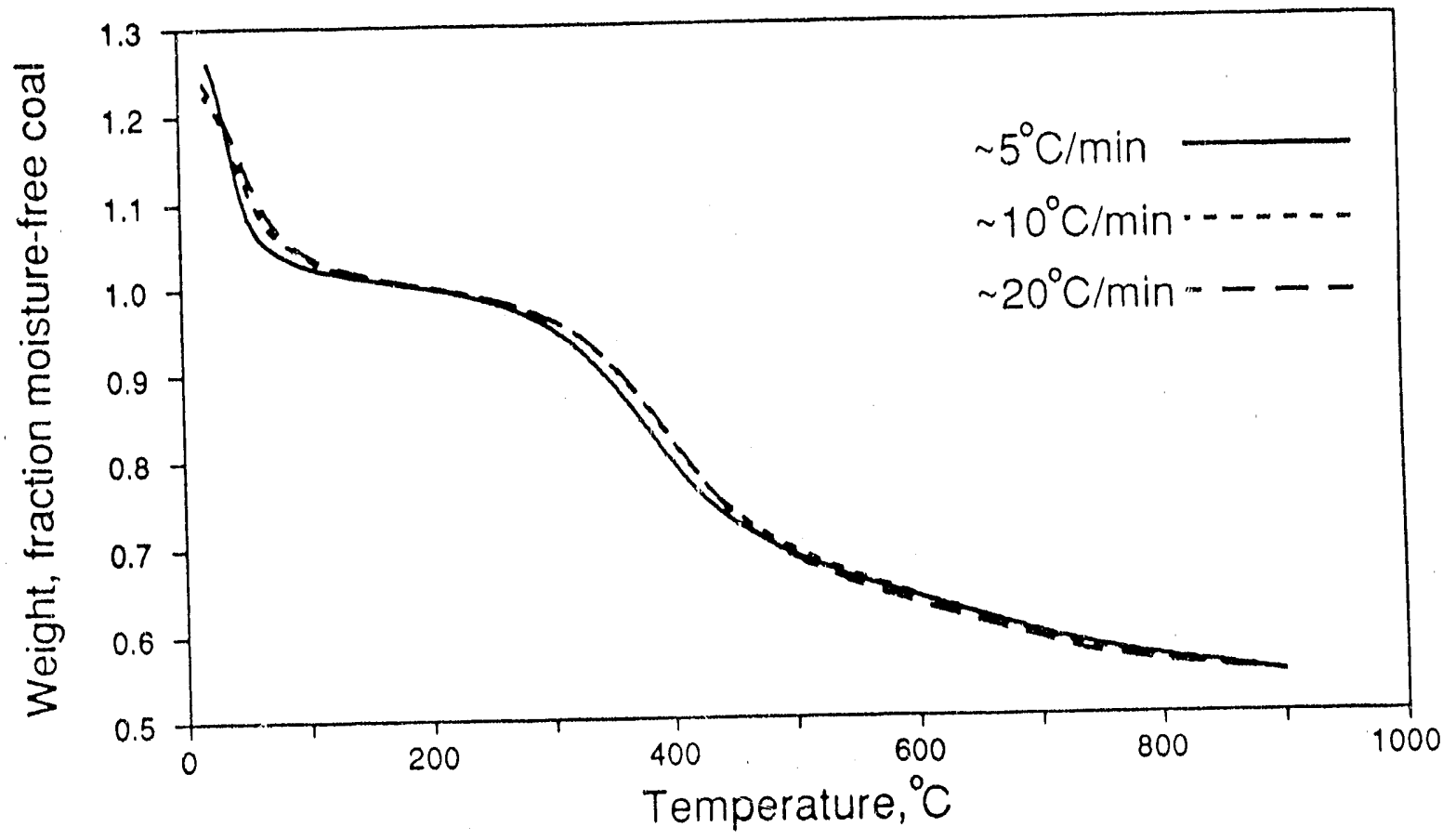

Figure 9. Normalized Weight Loss Profile of Usibelli Coal from Fundamental TGA Tests

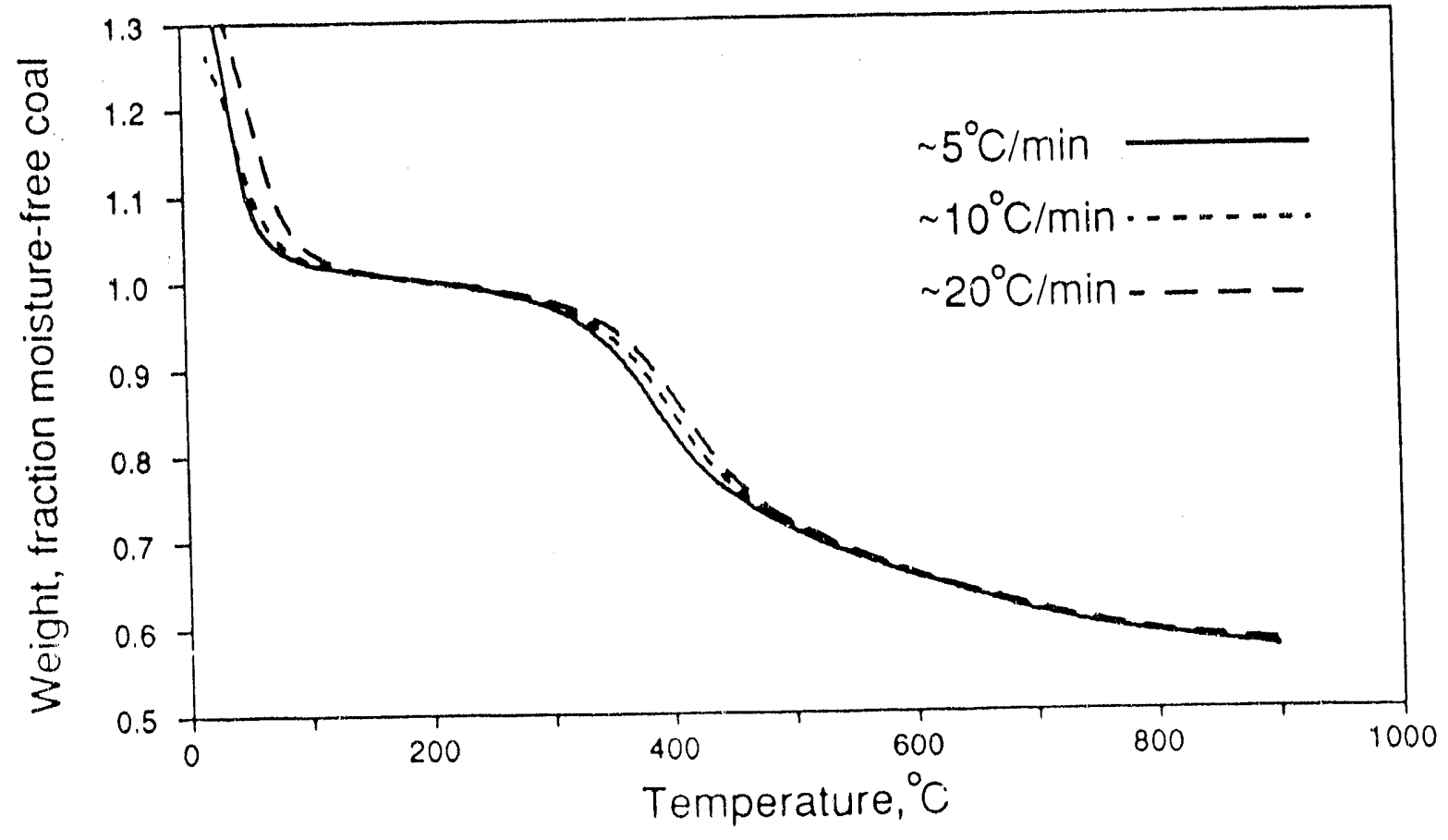

Figure 10. Normalized Weight Loss Profile for Eagle Butte Coal From Fundamental TGA Tests 


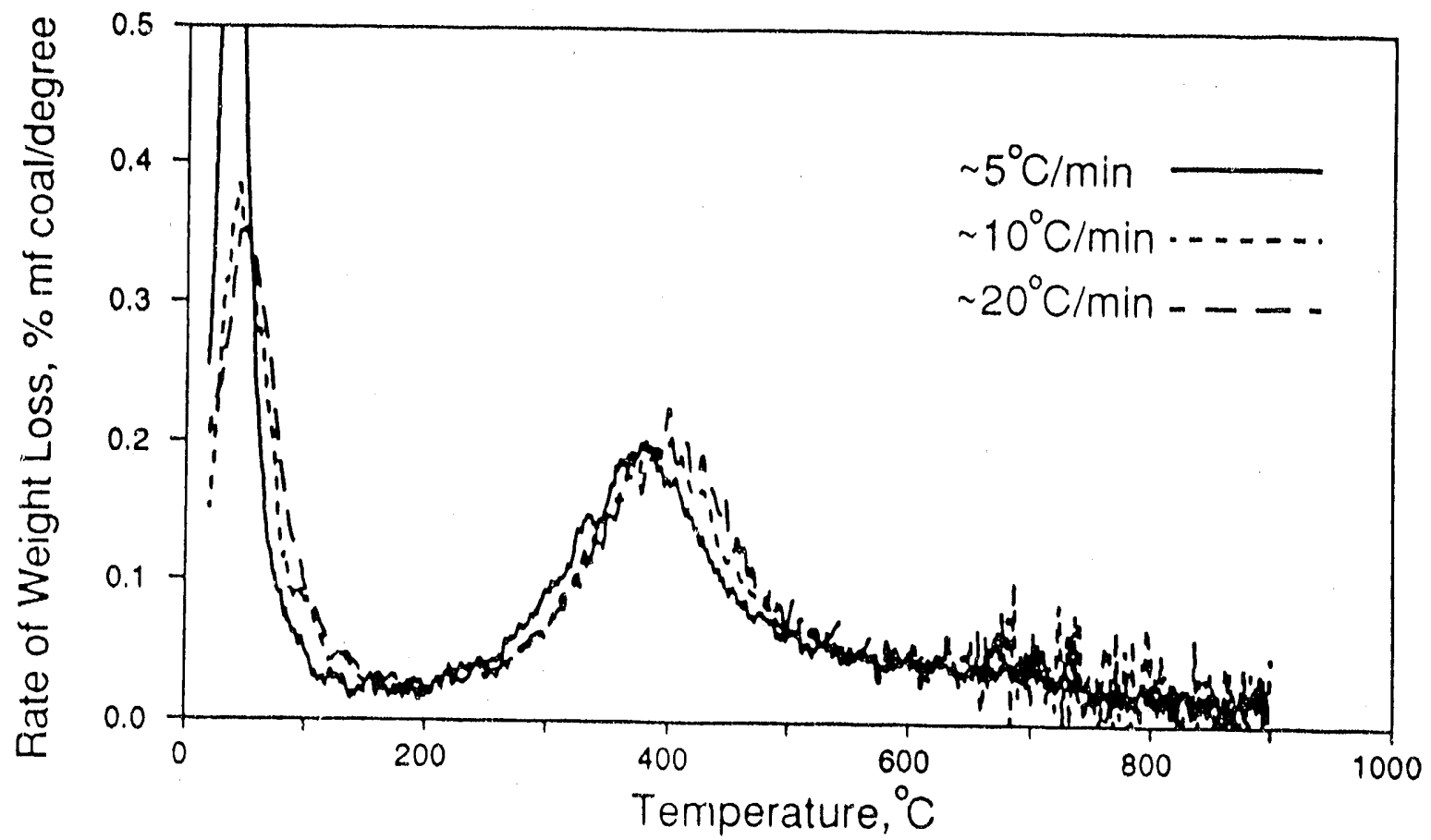

Figure 11. Rate of Weight Loss for Usibelli Coal

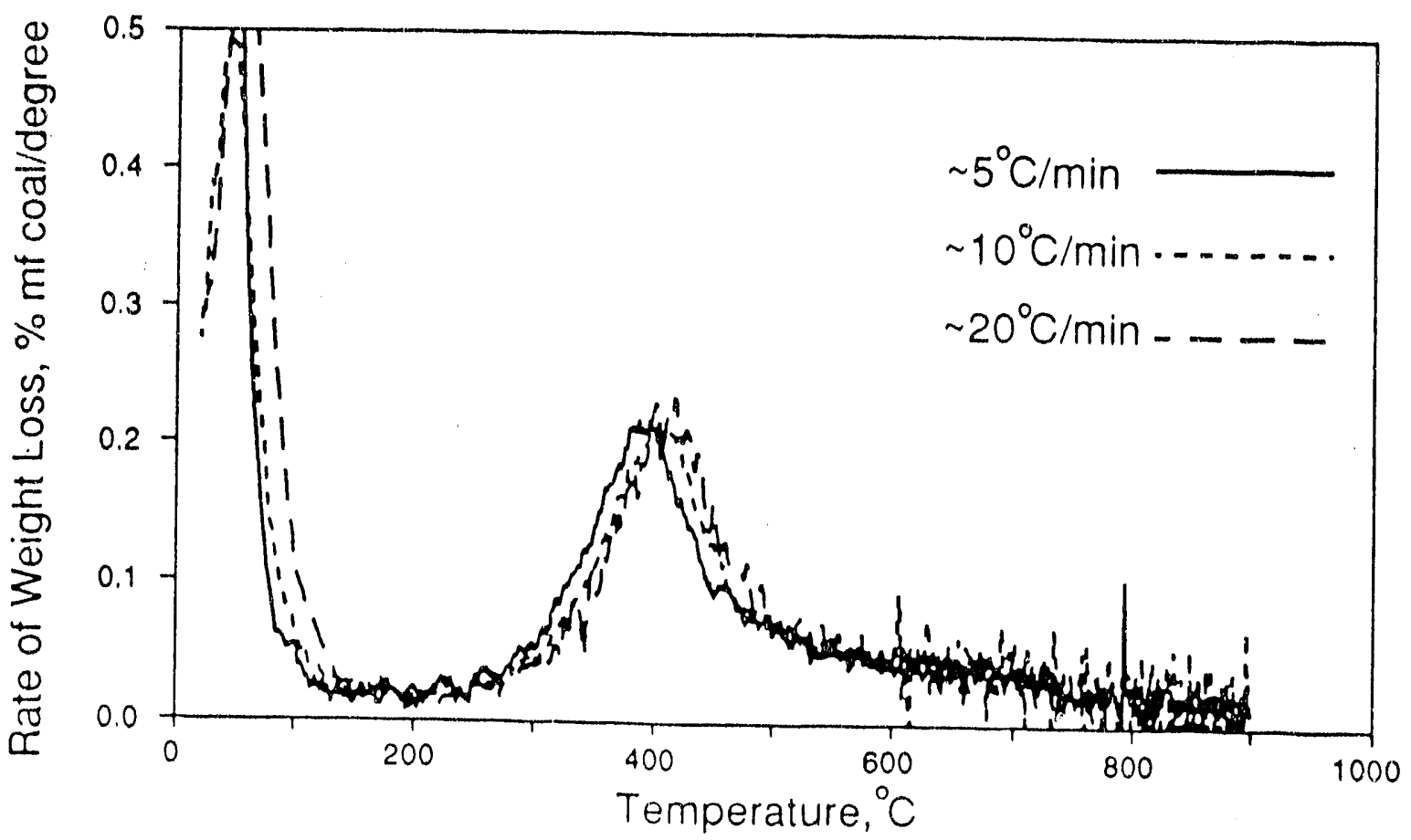

Figure 12. Rate of Weight Loss for Eagle Butte Coal 
The distinctive separation between water evolution and pyrolysis temperatures allows the kinetic analysis of the data to be unambiguously divided into two independent parts. The analysis of the water evolution portion of the data, less than $-150^{\circ} \mathrm{C}$ or $200^{\circ} \mathrm{C}$, can be performed separately from the analysis of the pyrolysis data, greater than $200^{\circ} \mathrm{C}$.

Figures 13 and 14 show the fits obtained in the application of Kinetics program to the pyrolysis weight-loss rates for Usibelii and Eagle Butte coals. These fits were generated using the "Discrete Activation Energies" mode of the software wherein a sum of first order reaction profiles with differing activation energies and a single frequency factor is assumed to fit the data. Data for al: heating rates for each coal were fit by simultaneous solution of the reaction equations.

The activation energy distributions necessary to fit the data for both coals are shown in Figures 15 and 16. The distributions are similar, centered at 43 and $45 \mathrm{kcal} / \mathrm{mole}$. However, the Usibelli coal has more low-activation-energy materiai than the Eagle Butte coal.

Water evolution profiles have been fit in the same manner as the pyrolysis curves. The best-fit curves show good agreement with the experimental data for both Usibelil and Eagle Eutte coals (Figures 17 and 18).

Activation energy distributions for water evolution from the Usibelil and Eagle Butte samples are shown in Figures 19 and 20 . These distributions indi ate that the Usibelij. coal requires more energy to remove water than dces the Eagle Butte coal. 


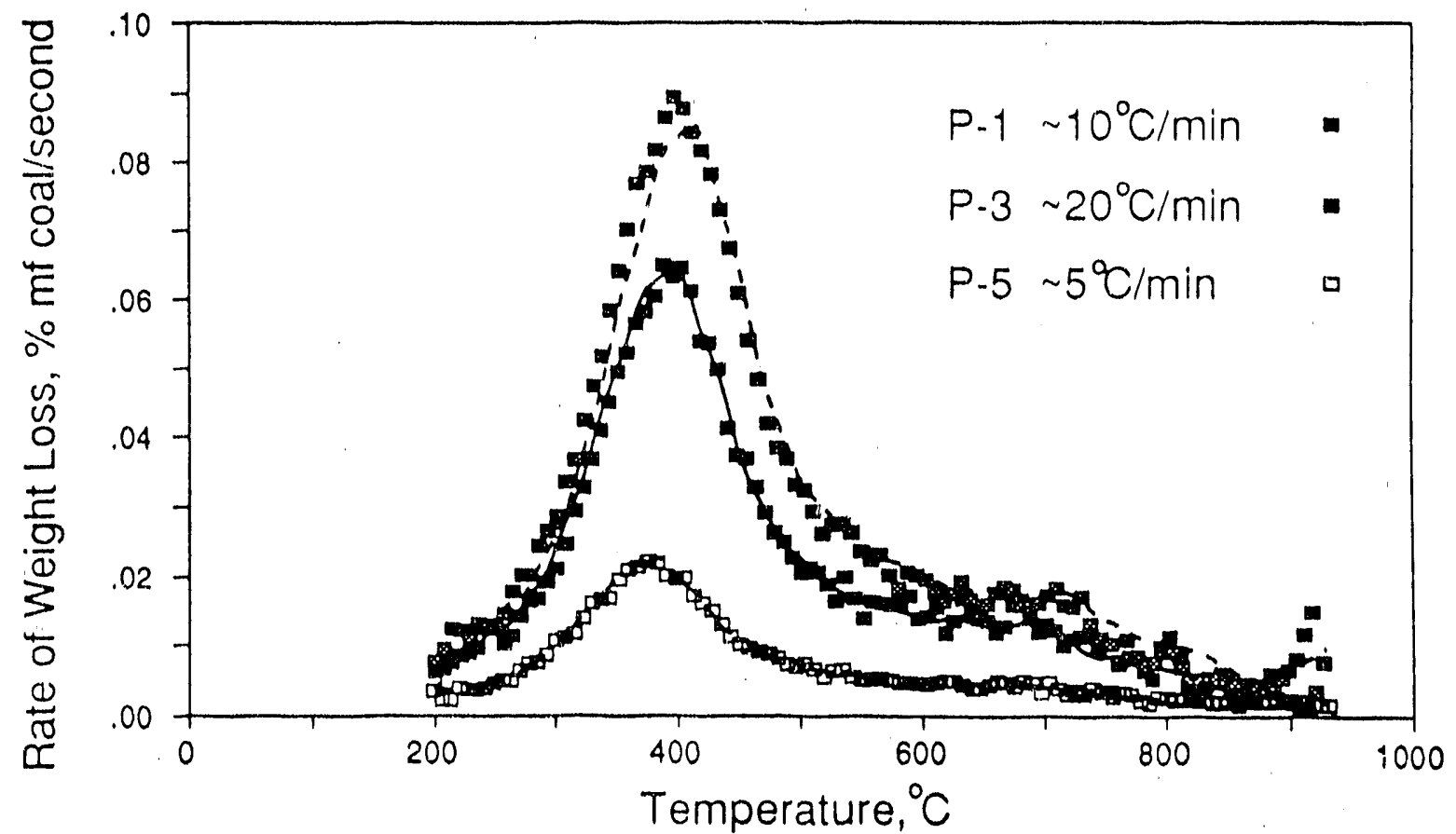

Figure 13. Kinetic Fits to Pyrolysis Weight Loss Rates for Jsibelli Coal

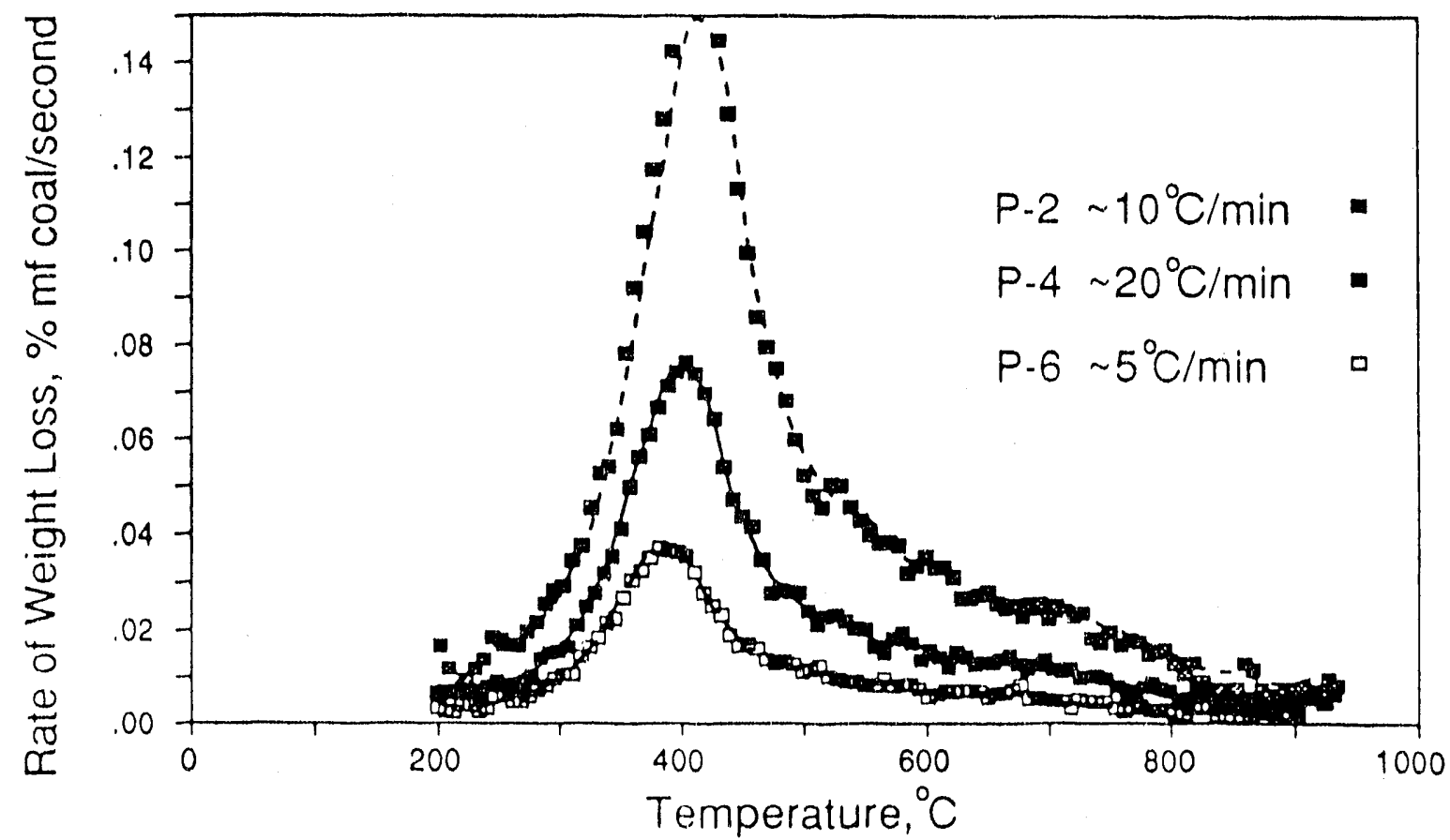

Figure 14. Kinetic Fits to Fyrolysis Weight Loss Rate for Eagle Butte Coal 


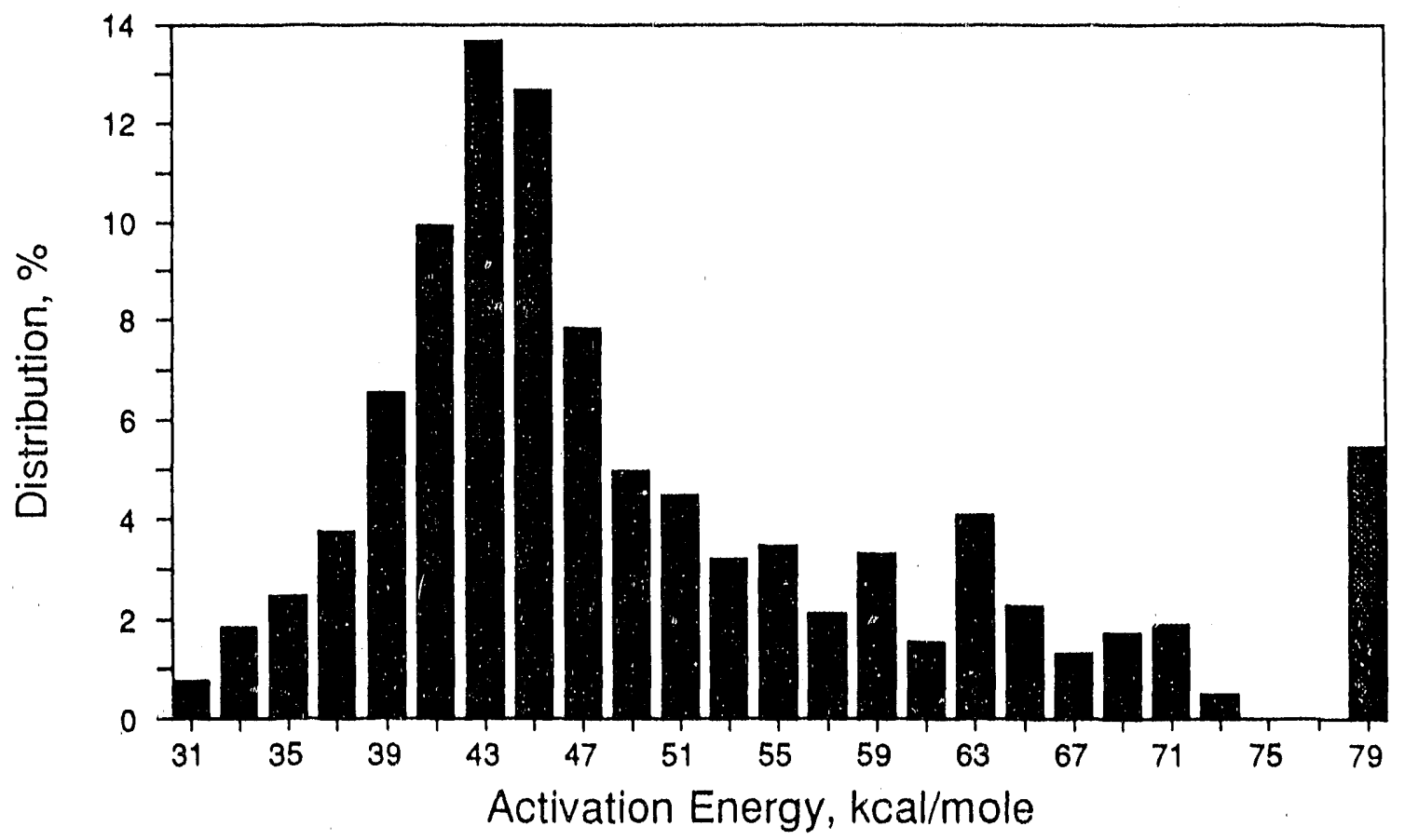

Figure 15. Activation Energy Distribution for Pyrolysis Waight Loss of Usibelli Coal

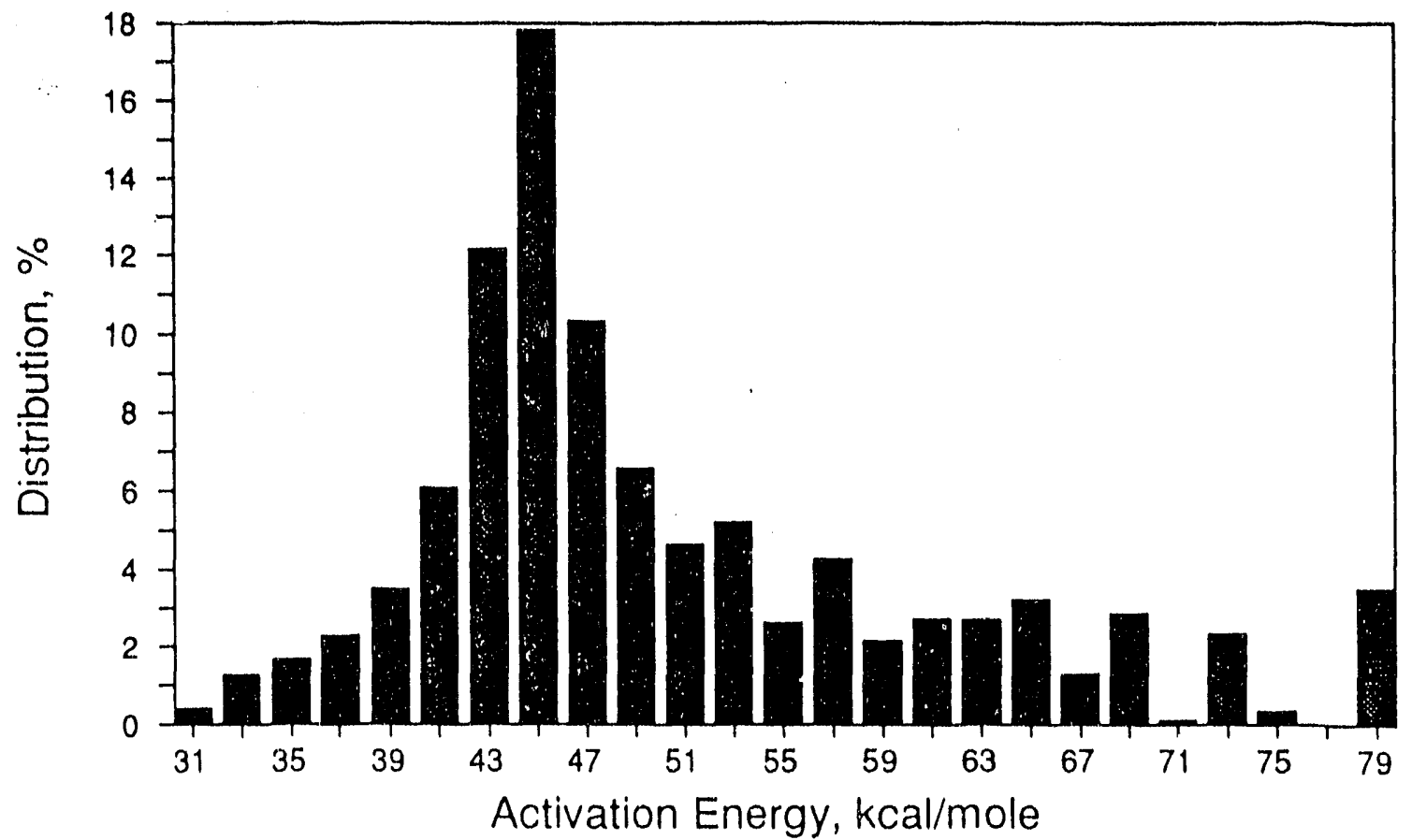

Figure 16. Hetivation Energy Distribution for Pyrolysis Weight Loss of Eagle Butte Coal 


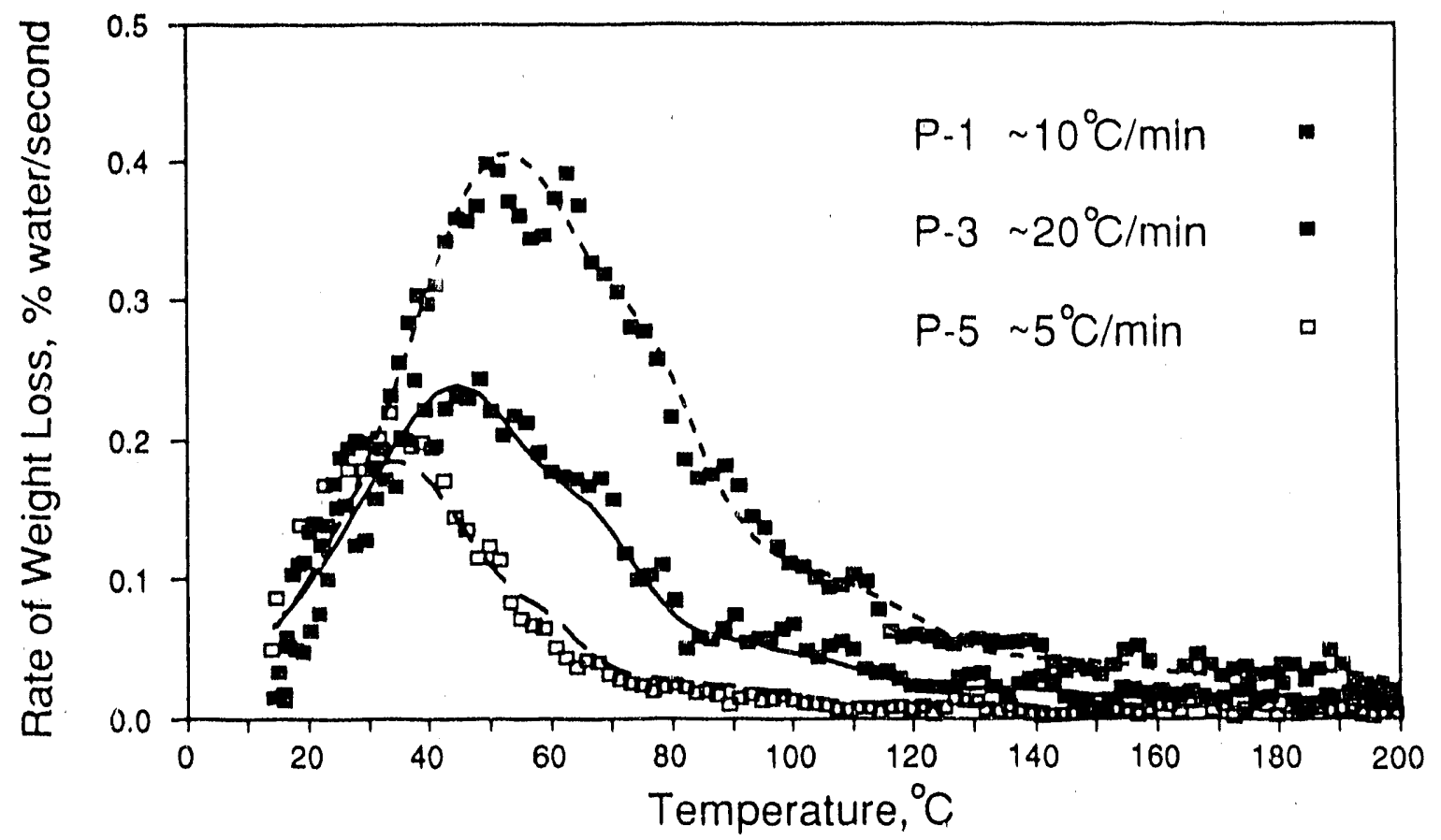

rigure 17. Kinetic $\mathbf{r}$. Ks to Water Weight Loss for Usibelli Coal

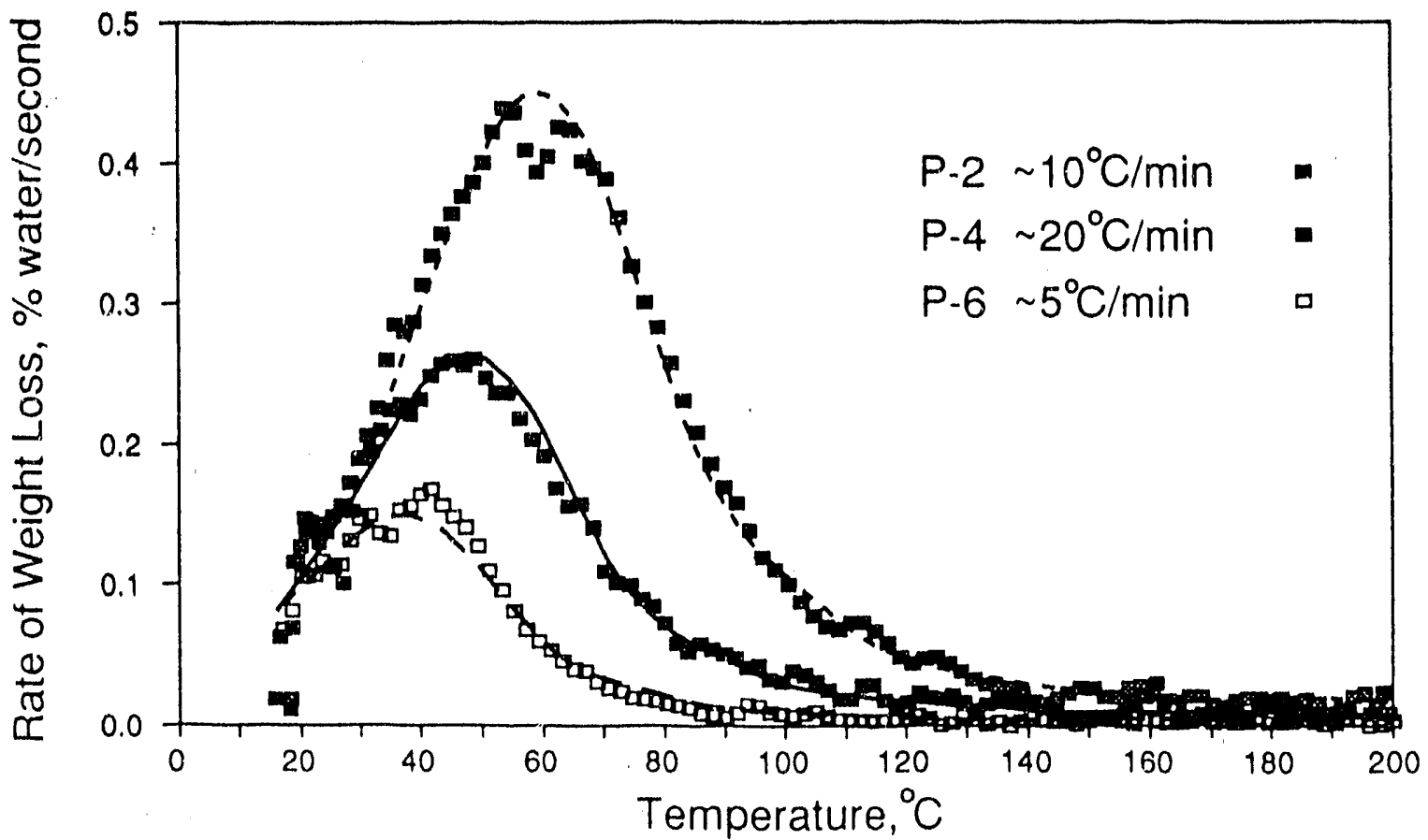

Figure 18. Kinetic rits to Water Weight Loss for Eagle Butte Coal 


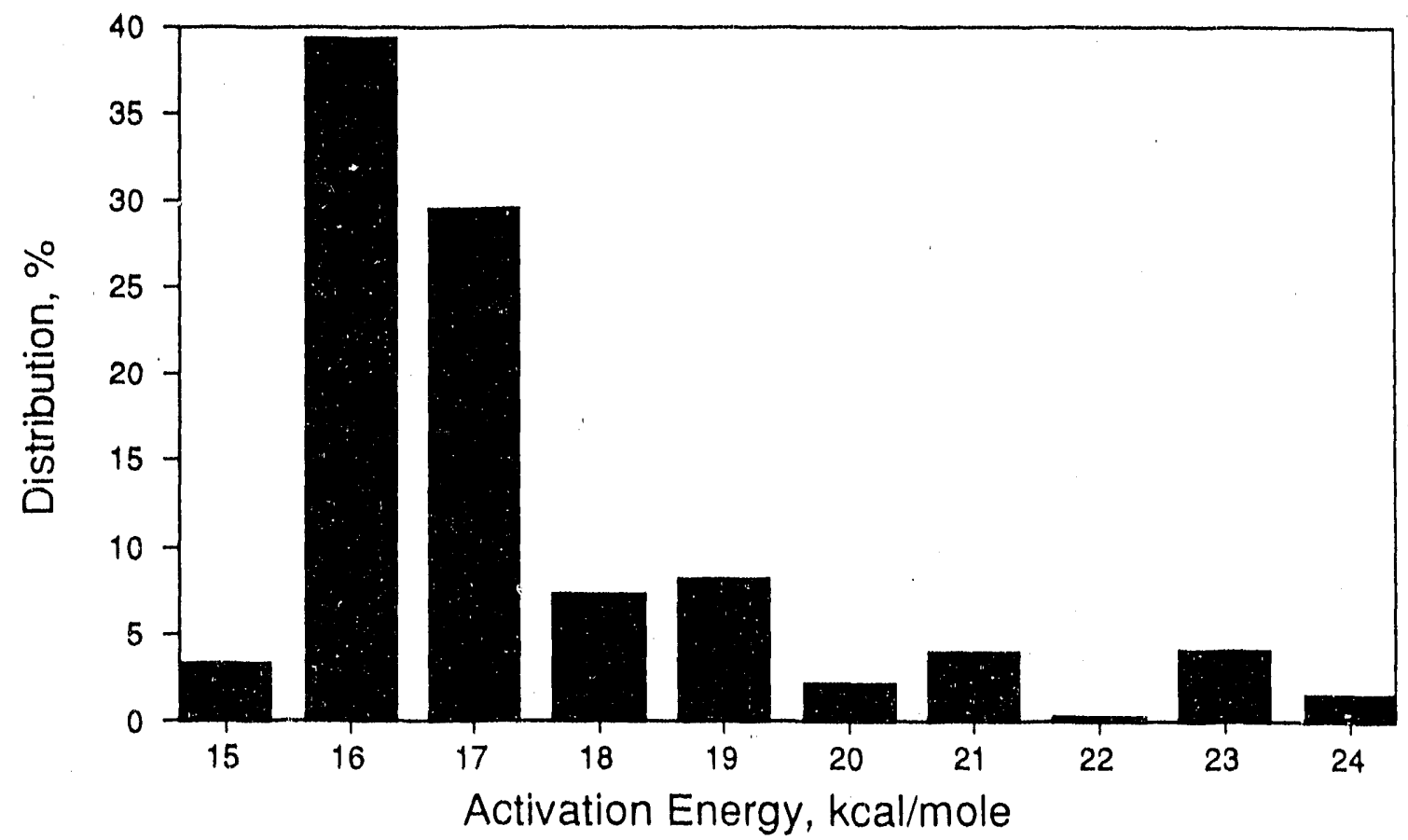

rigure 19. Activation rnergy Distribution for Water Waight Loss of Uaibelii Coal

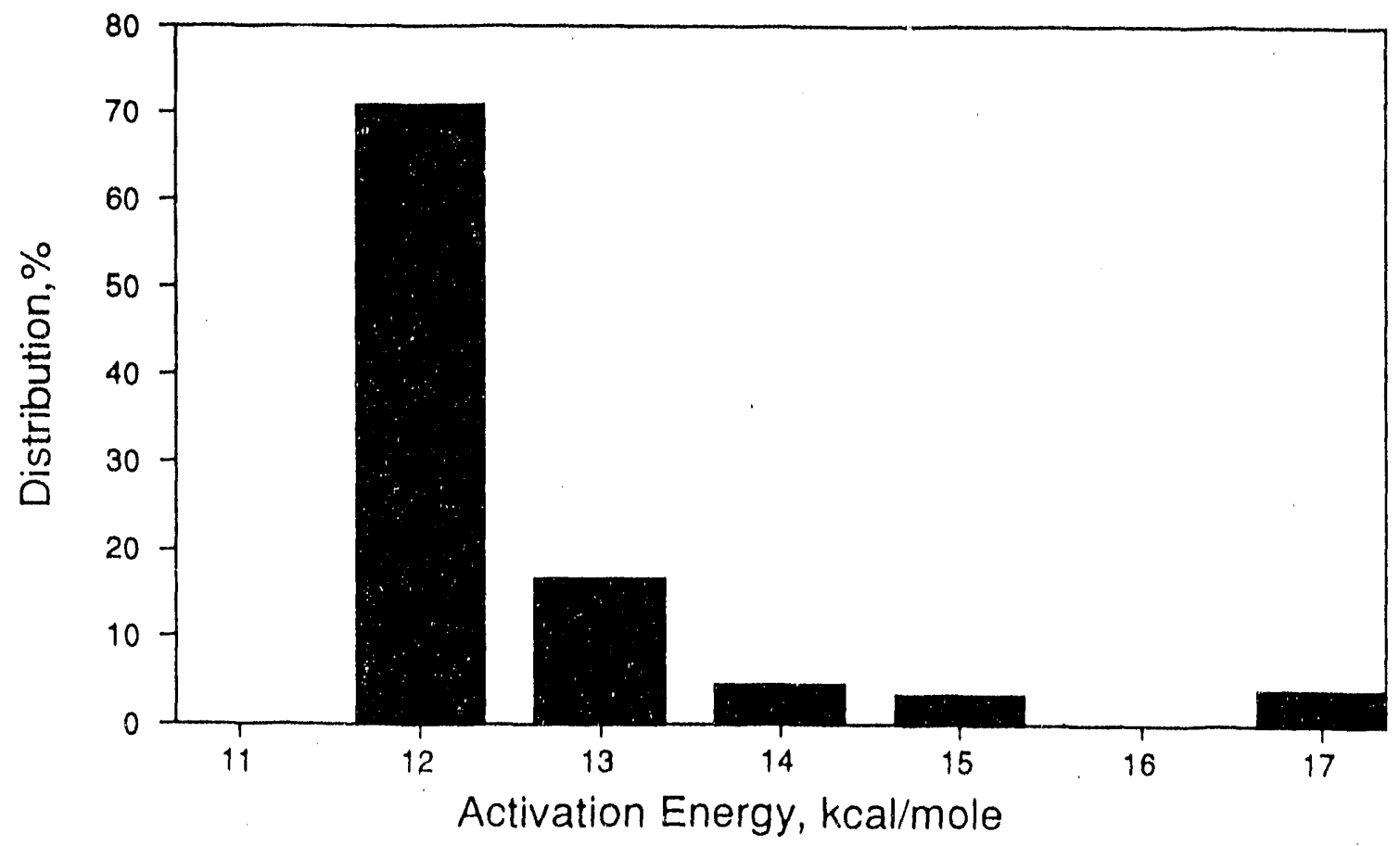

Figure 20. Activation Energy Distribution for Water Weight Loss of Eagle Butte Coal 
Subtask 2.3 Optimizirg TGA Studies

Optimizing TGA studies were performed on the Cahn 131 TGA sjstem to generate data on product gas evolved during heating. A summary of the run conditions and material balance data for the Cahn TGA experiments on the Eagle Butte and Usibelli coals are shown in Table 4. On a moisture-free basis the percentage of residual materials (char) is 58.8 and 55.3 weight percent for the Eagle Butte and Usibelli coals, respectively. These data compare favorably with those values in Table 3 .

The rates of weight-loss curves for the two coals shown in Figure 21 and Figure 22 were derived from the Cahn TGA tests and can be compared with the results from the Dupont "GA tests in Figures 11 and 12 . Tre only significant difference in the profiles from the two systems is a slight shift in the temperature for maximum rate of water evolution. This difference may be due to the sample holder and sweep gas flow configurations of the two systems. For the Dupont 951, the sweep gas flows through the sample holder keeping the partial pressure of volatile components low. The Cahn 131 has a bucket-shaped sample holder with the sweep gas flowing around, but not through the holder. The partial pressure of volatile components will be higher in the Cahn system restricting the rate of evolution. For both systems and both coals free water is removed below $200^{\circ} \mathrm{C}$. 
Table 4. Optimizing TGA Experimental Material Balance Summary

Experimental Conditions

Run Length, $\mathrm{min}$

Helium Sweep Rate, scc/min

Final Temperature, ${ }^{\circ} \mathrm{C}$

Heating Rate, ${ }^{\circ} \mathrm{C} / \mathrm{min}$

Sample Weight, grams

$$
\begin{array}{r}
98.25 \\
100.00 \\
990.00 \\
10.15 \\
0.424
\end{array}
$$

Usibelli Coal
98.30
100.00
991.00
10.13
0.246

Gas Composition, wt $q$

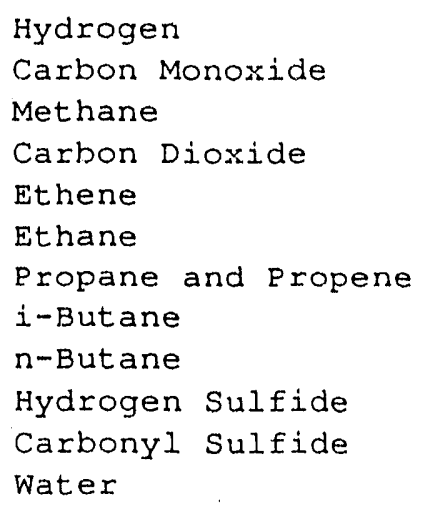

Hydrogen

Carbon Monoxide

Methane

Carbon Dioxide

Ethene

Ethane

Propane and Propene

i-Butane

n-Butane

Hydrogen sulfide

Carbonyl sulfide

water

Material Balance, wt $\$$
0.909

9.956

1. 842

11.895

1.126

0.186

0.321

0.230

0.138

0.030

0.020

12.402

26.65

39.09

Water and Oil (CSt)

47.93

54.65

43.63

43.11

Extract

0.00

0.00

Recovery, wt o

118.22

136.84 


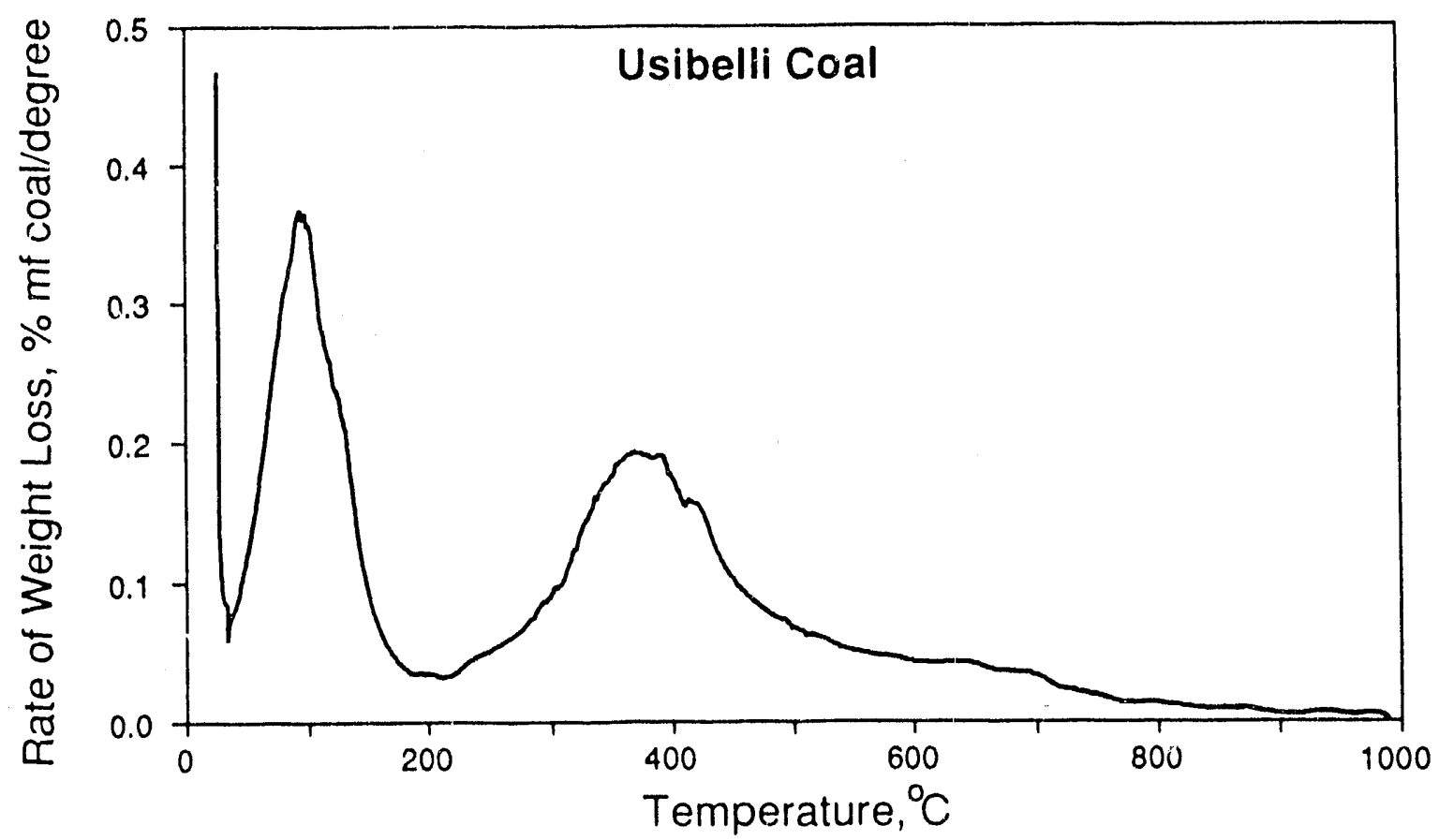

Figure 21. Rate of Weight Loss for Usibelli Coal from Optimizing TGA Tesis

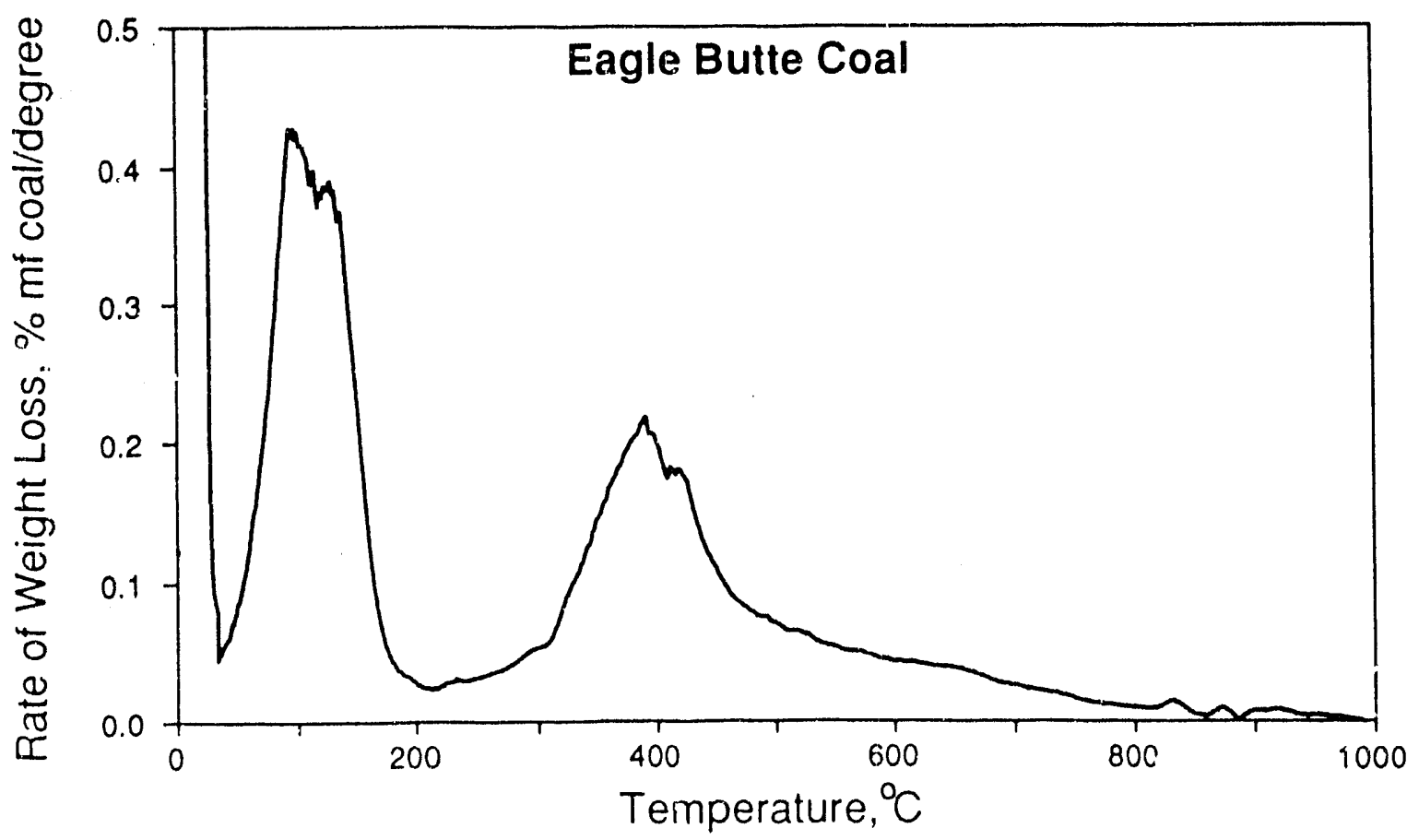

Figure 22. Rate of Weight Loss for Eagle Butte Coal from Optimizing TGA Tests 
The evolution rates of carbon dioxide, carbon monoxide, hydrogen, methane, ethane, ethene, propane and propene, iso-butane, and n-butane from the Eagle Butte and Usibelli coals are shown in Figure 23. In some cases the gas concentrations were near the detection limits of the evolved gas analysis system (eg. n-butane from Usibelli; iso- and n-butane from Eagle Butte). In general, the hydrocarbon gases have maximum rates of evolution just above $400^{\circ} \mathrm{C}\left(752^{\circ} \mathrm{F}\right)$. Methane has a broader evolution peak with a maximum near $500^{\circ} \mathrm{C}\left(932^{\circ} \mathrm{F}\right)$. Ethene has a maximum rate of evolution near $400^{\circ} \mathrm{C}\left(752^{\circ} \mathrm{F}\right)$ but also evolves at a lower rate up to $800^{\circ} \mathrm{C}\left(1,472^{\circ} \mathrm{F}\right)$. Carbon dioxide has a broad evolutior profile starting near $100^{\circ} \mathrm{C}\left(212^{\circ} \mathrm{F}\right)$ and extending to $1,000^{\circ} \mathrm{C}\left(1,832^{\circ}\right)$. The maximum rate of evolution is near $400^{\circ} \mathrm{C}\left(752^{\circ} \mathrm{F}\right)$. Hydrogen is not formed in significant amounts below $500^{\circ} \mathrm{C}$ $\left(932^{\circ} \mathrm{F}\right)$. The maximum hydxogen evolution rate is near $600^{\circ} \mathrm{C}\left(1,112^{\circ} \mathrm{F}\right)$ for the Usibelli coal and near $700^{\circ} \mathrm{C}\left(1,292^{\circ} \mathrm{F}\right)$ for the Eagle Butte coal.

Optimum coal drying conditions have been estimated by examining the water and pyrolysis gas evolution profiles. Optimal conditions are developed in which the moisture is removed and mobile non-volatile products seal the coal pores to prevent water uptake.

A key element of the Kinetic program is the capability to extrapolate (based on data acquired on lab scale instruments) to arbitrary thermal histories. Weight loss profiles and rates can be generated for any heating rate of interest. This has been accomplished for each of the two coal samples. 
EAGLE BUTTE COAL
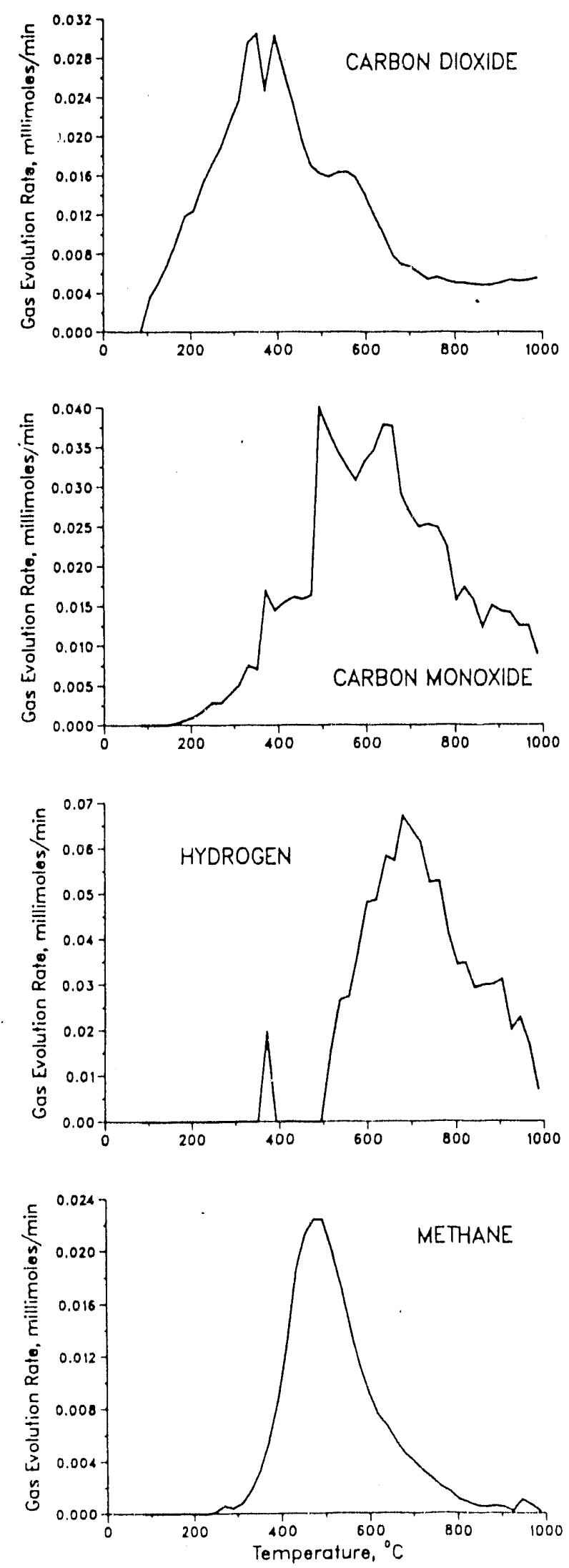

USIBELLI COAL
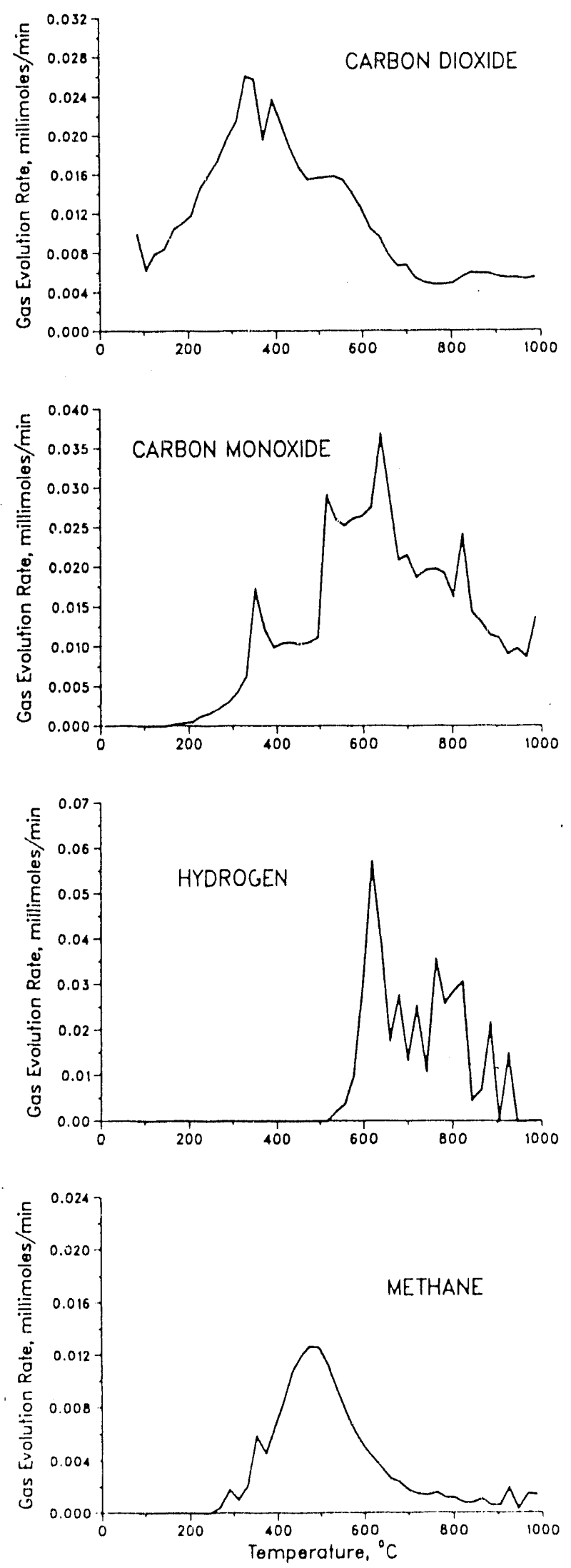

rigure 23. Pyrolysis Gas Evolution versus Temperature for Usibelli and sad zasle Rutte Cozis 
EAGLE BUTTE COAL.
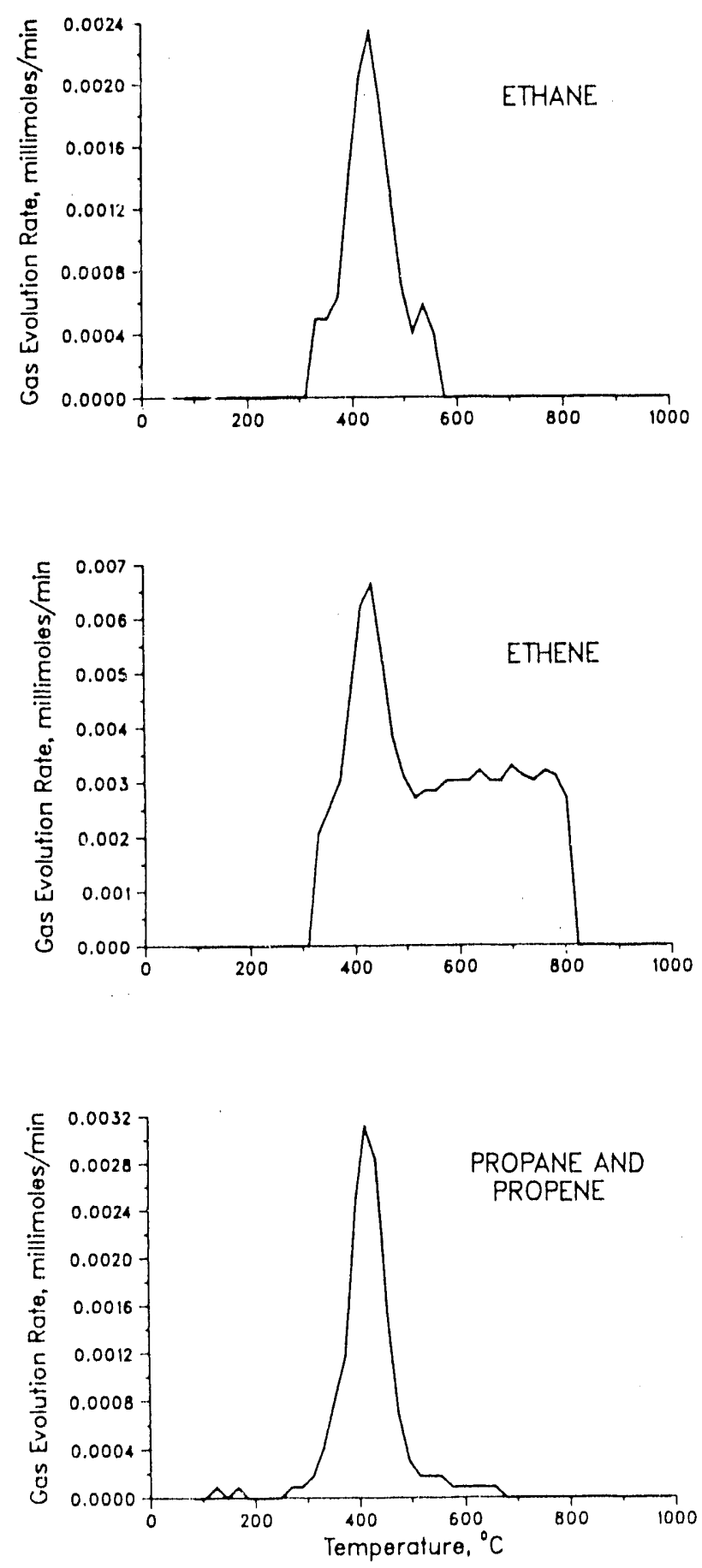

USIBELLI COAL
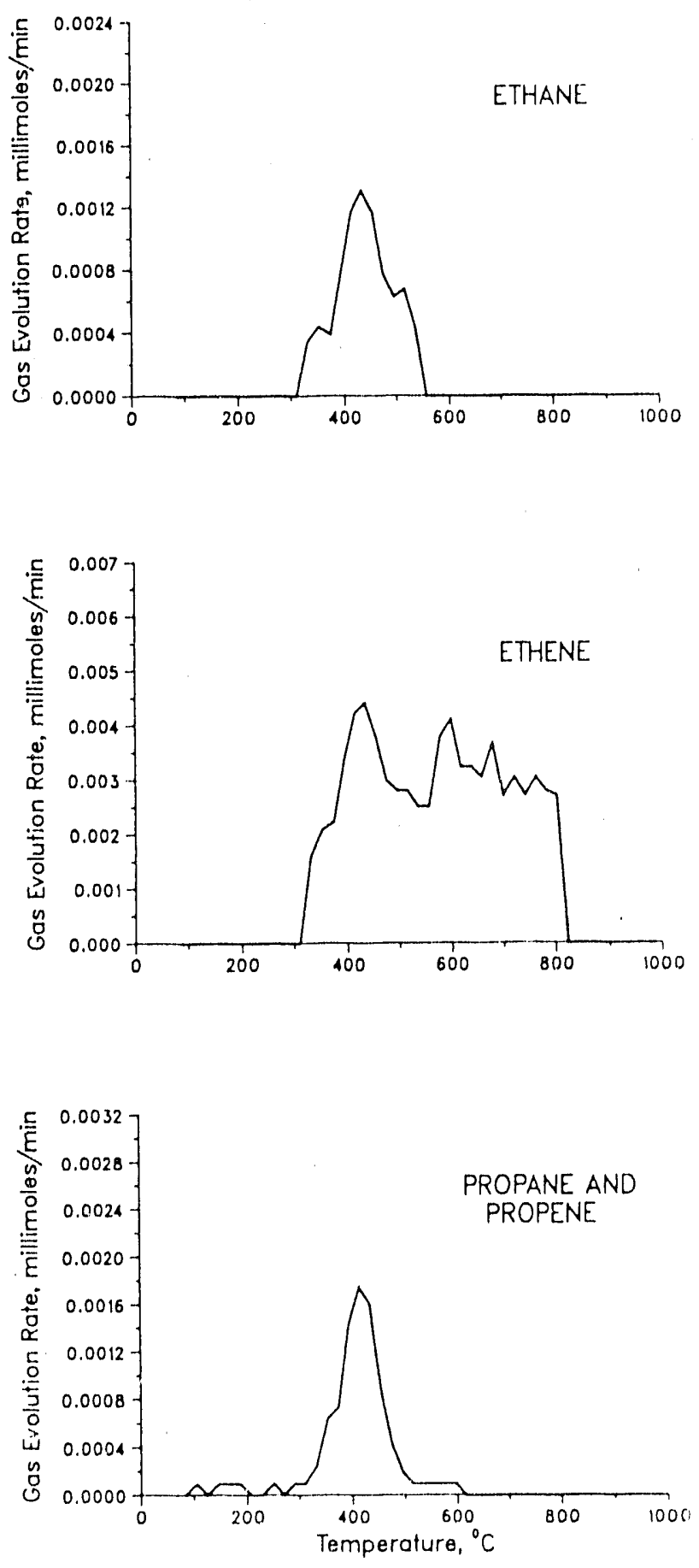

Figure 23. Pyrolysis Gas Evolution versus Temperature for Usibelli and Eagle Butte Coal (continued) 
EAGLE BUTTE COAL
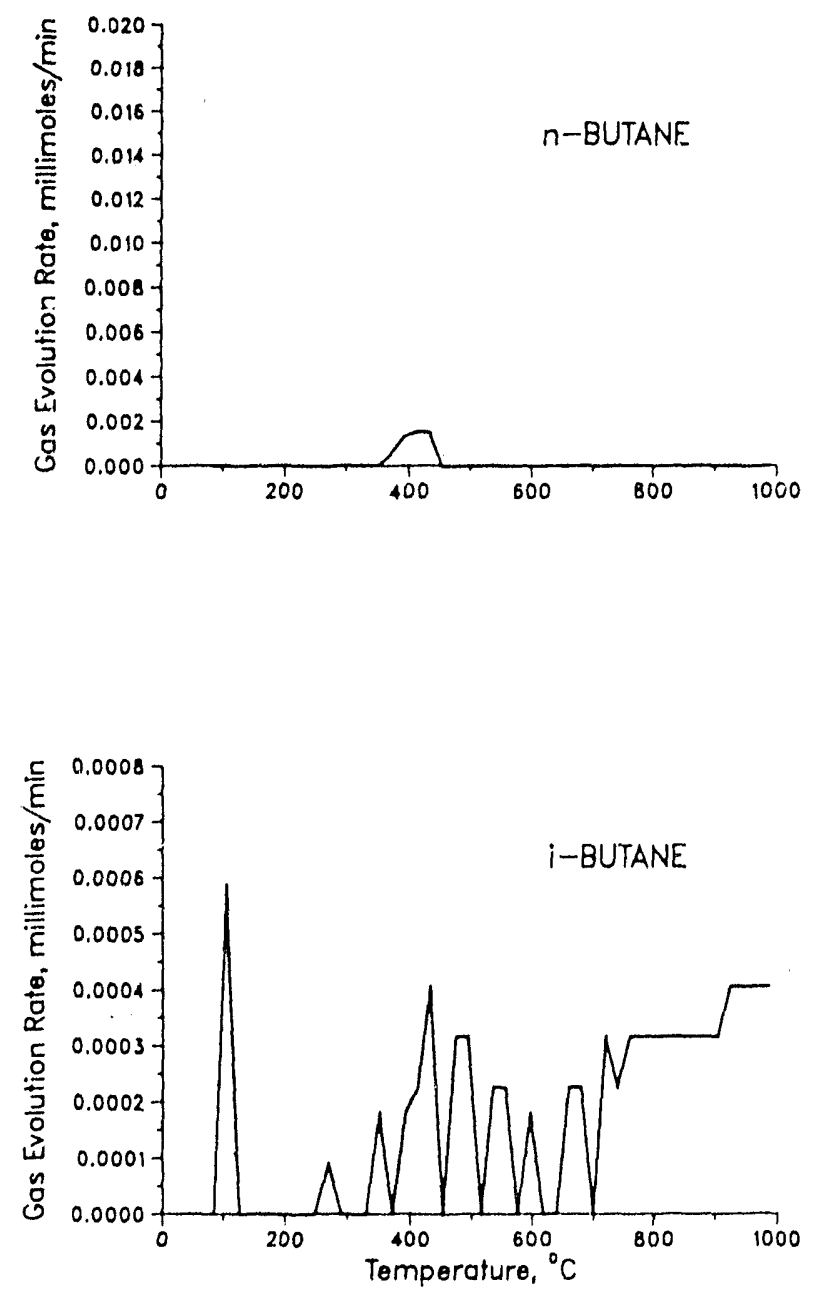

USIBELI COAL
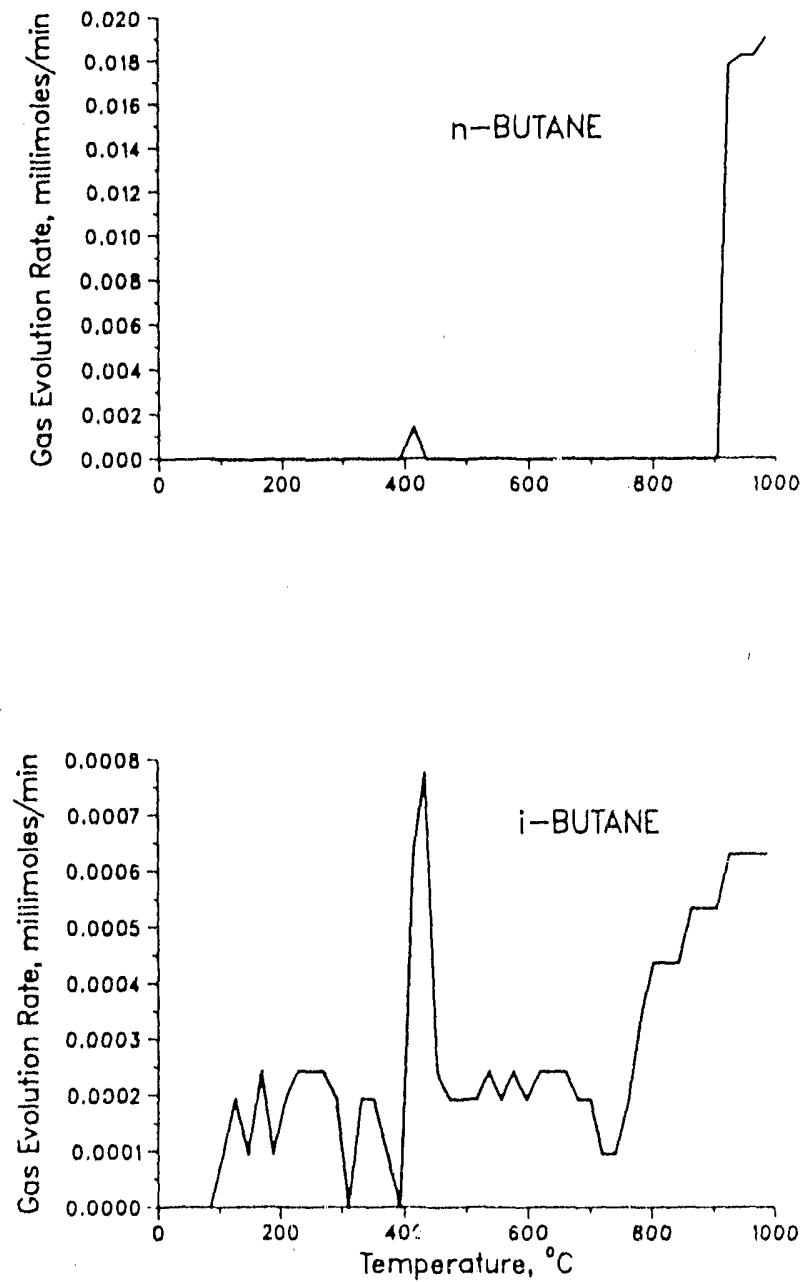

Figure 23. Pyrolysis Cas Evolution versus Temperaturo for llaibelli and Eagle Butte Coal (Concluded) 
The heating rate in the inclined-fluidized-bed drier is estimated to be approximately $55.6^{\circ} \mathrm{C} / \mathrm{minute}\left(100^{\circ} \mathrm{F} / \mathrm{minute}\right)$. Anticipated conversion and rate of conversion for pyrolysis of the Usibelli coal are plotted in Figures 24 and 25 in a temperature range encompassing the onset of pyrolysis. Equivalent curves are shown in Figures 26 and 27 for the Eagle Butte coal. The plots of pyrolysis conversion can be used to select appropriate residence times (or maximum temperatures) in the reactor. For example, if one wishes to quench the reaction after $10 \%$ of the pyrolysis occurs, the reaction must be stopped at $350^{\circ} \mathrm{C}\left(662^{\circ} \mathrm{F}\right)$ for each coal. The residence time can be calculated based on the starting temperature and the heating rate.

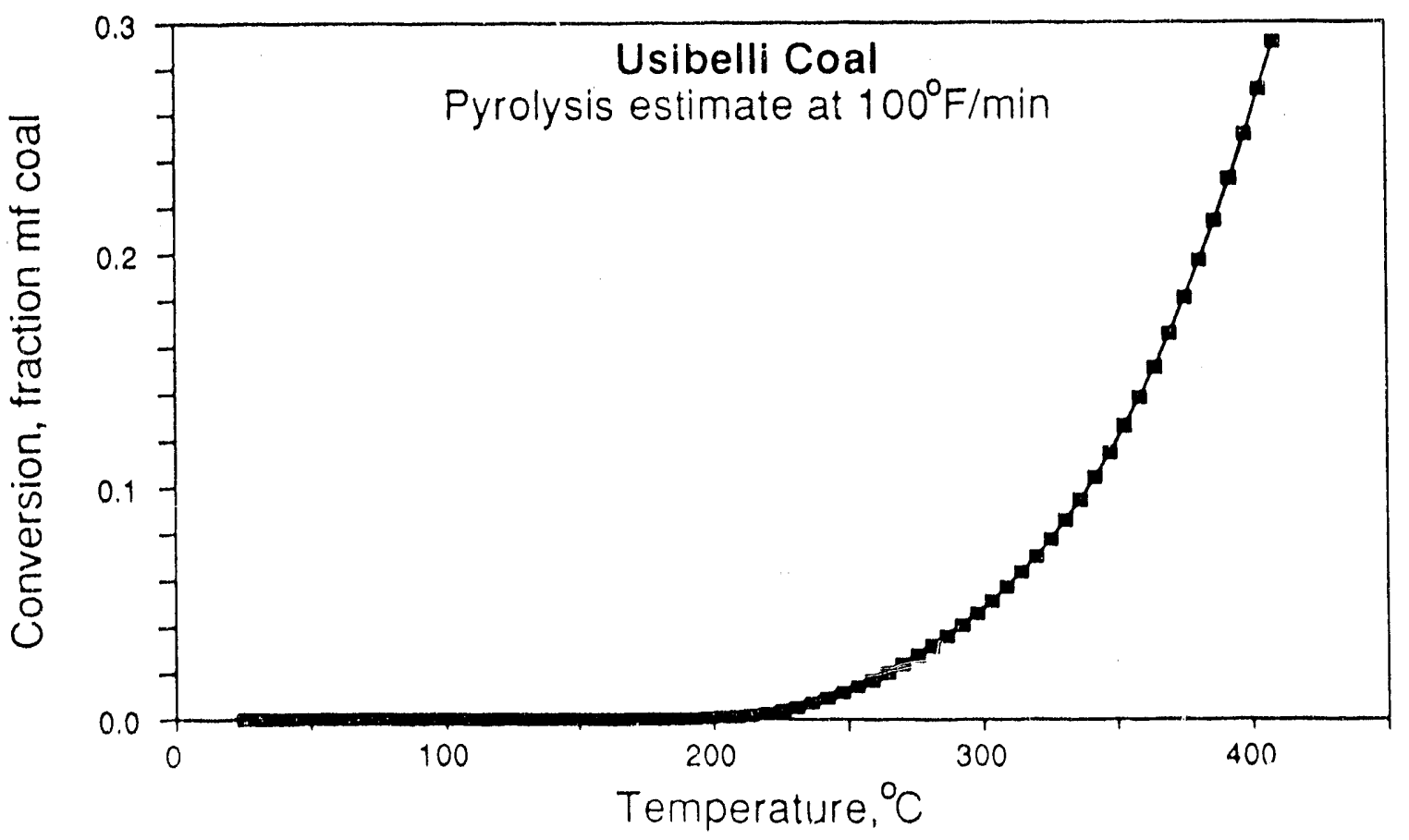

Figure 24. Estimated Pyrolysis Conversion for Usibelli Coal at $100^{\circ} \mathrm{F} / \mathrm{min}\left(55.6^{\circ} \mathrm{C} / \mathrm{min}\right)$ 


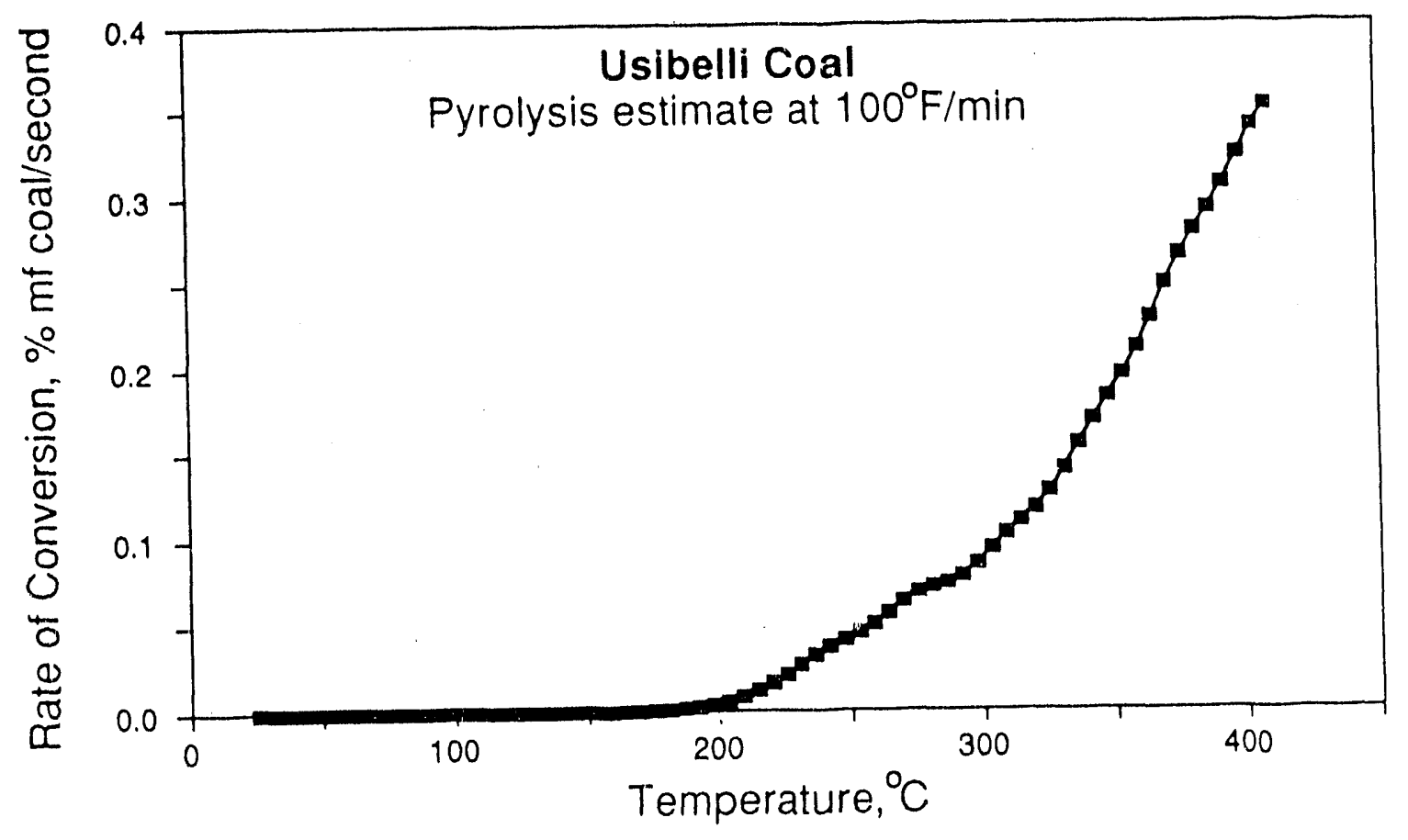

Figure 25. Estimated Rate of Pyrolysis Converstion for Usibelli Coal at $100^{\circ} \mathrm{F} / \mathrm{min}\left(55.6^{\circ} \mathrm{C} / \mathrm{min}\right)$

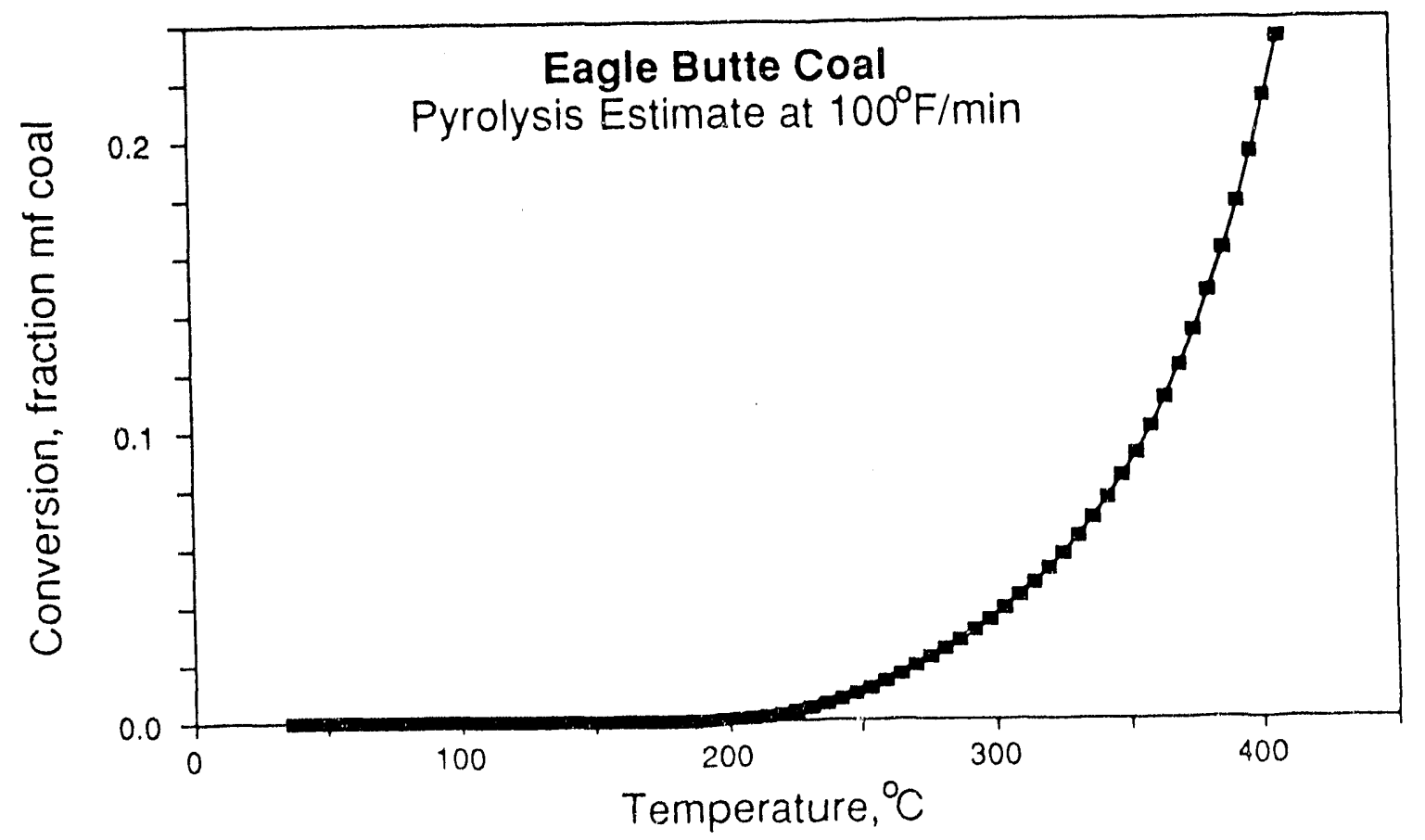

Figure 26. Estimated Pyrolysis Converstion for Eagle Butte Coal at $100^{\circ} \mathrm{F} / \mathrm{min}(55.6 \% \mathrm{~min})$ 


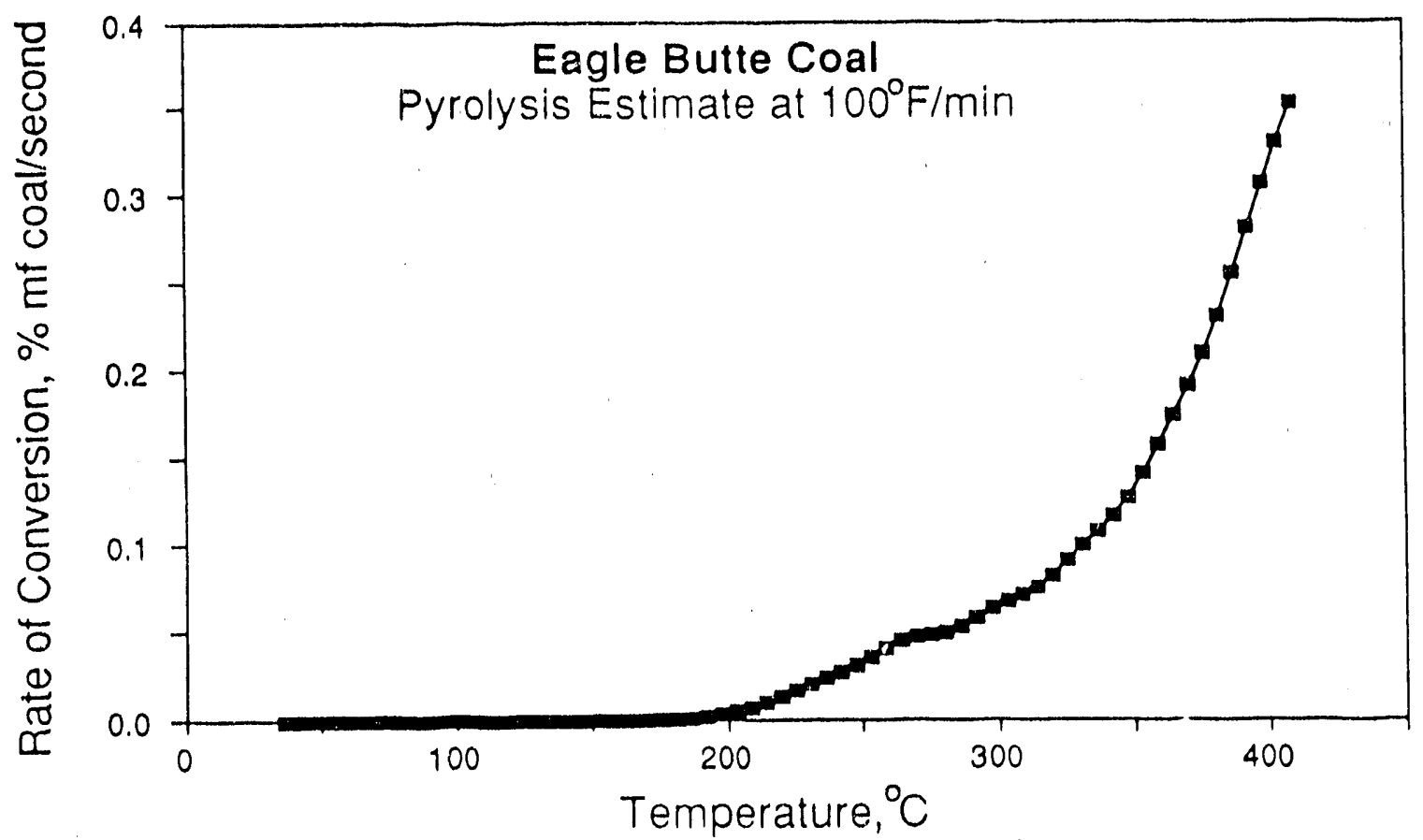

rigure 27. Estimated Rate of Pyrolysis Conversion for Eagle Butte Coal at $100^{\circ} \mathrm{F} / \mathrm{min}\left(55.6^{\circ} \mathrm{C} / \mathrm{min}\right)$

Figure 23 can then be used to estimate the composition of the pyrolysis gas evolved at the selected temperature. This information would be useful in estimating the recycle gas composition in a commercial operation.

In addition, estimated conversion and rate of conversion for water evolutiun from the Usibelli coal are shown in Figures 28 and 29 for a heating rate of $55.6^{\circ} \mathrm{C} / \mathrm{min}\left(100^{\circ} \mathrm{F} / \mathrm{min}\right)$. The equivalent profileg for Eagle Butte coal are shown in Figures 30 and 31 . For both coals 908 of the free water is removed at or below $150^{\circ} \mathrm{C}\left(302^{\circ} \mathrm{F}\right)$. The mainimm rate of water evolution occurs below $100^{\circ} \mathrm{C}\left(212^{\circ} \mathrm{F}\right)$ at atmospherio conditions in Laramie, Wyomning (11.7 psia). 


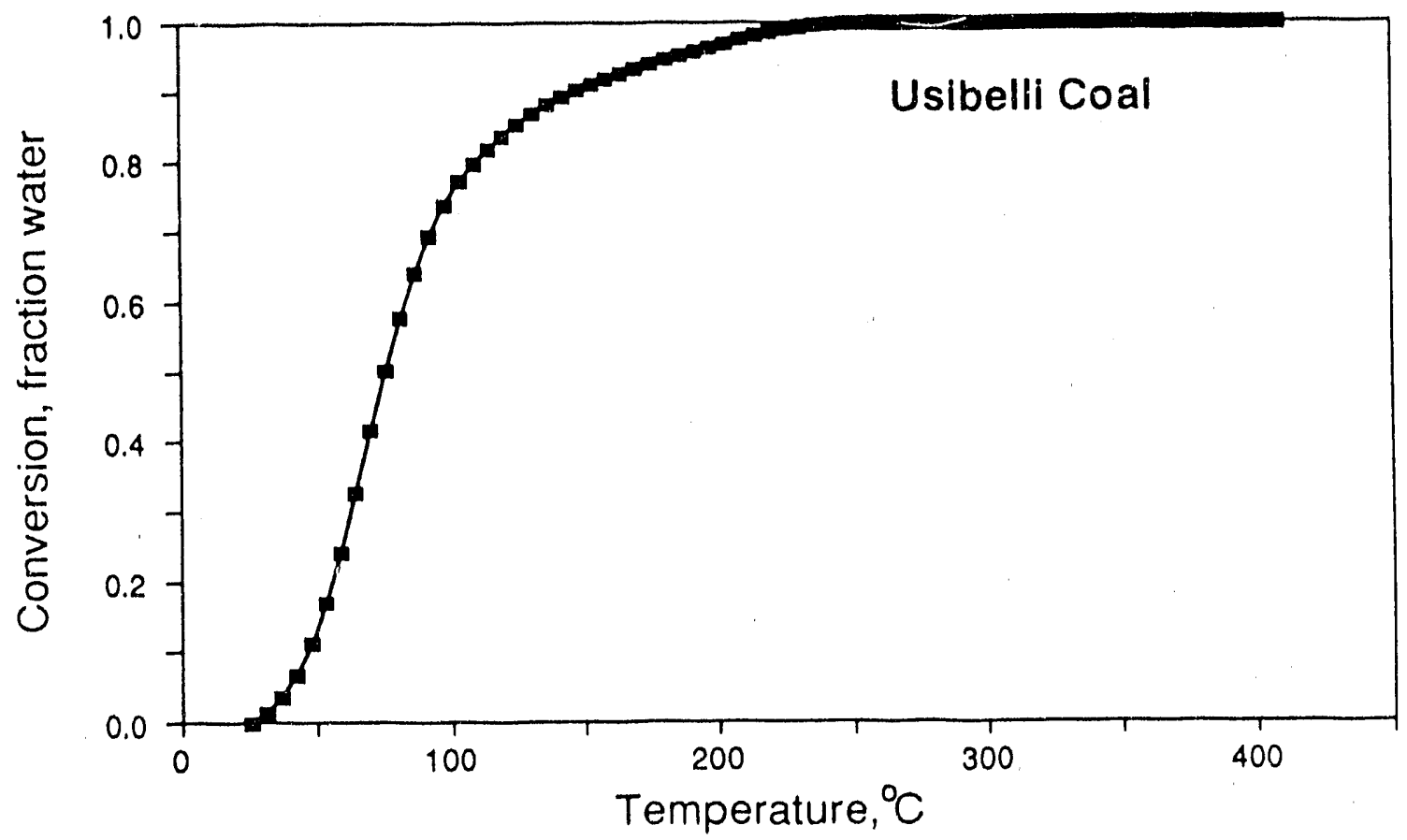

Figure 28. Estimated Cumulative Water Evolution for Usibelli Coal at $100^{\circ} \mathrm{F} / \mathrm{min}\left(55.6^{\circ} \mathrm{C} / \mathrm{min}\right)$

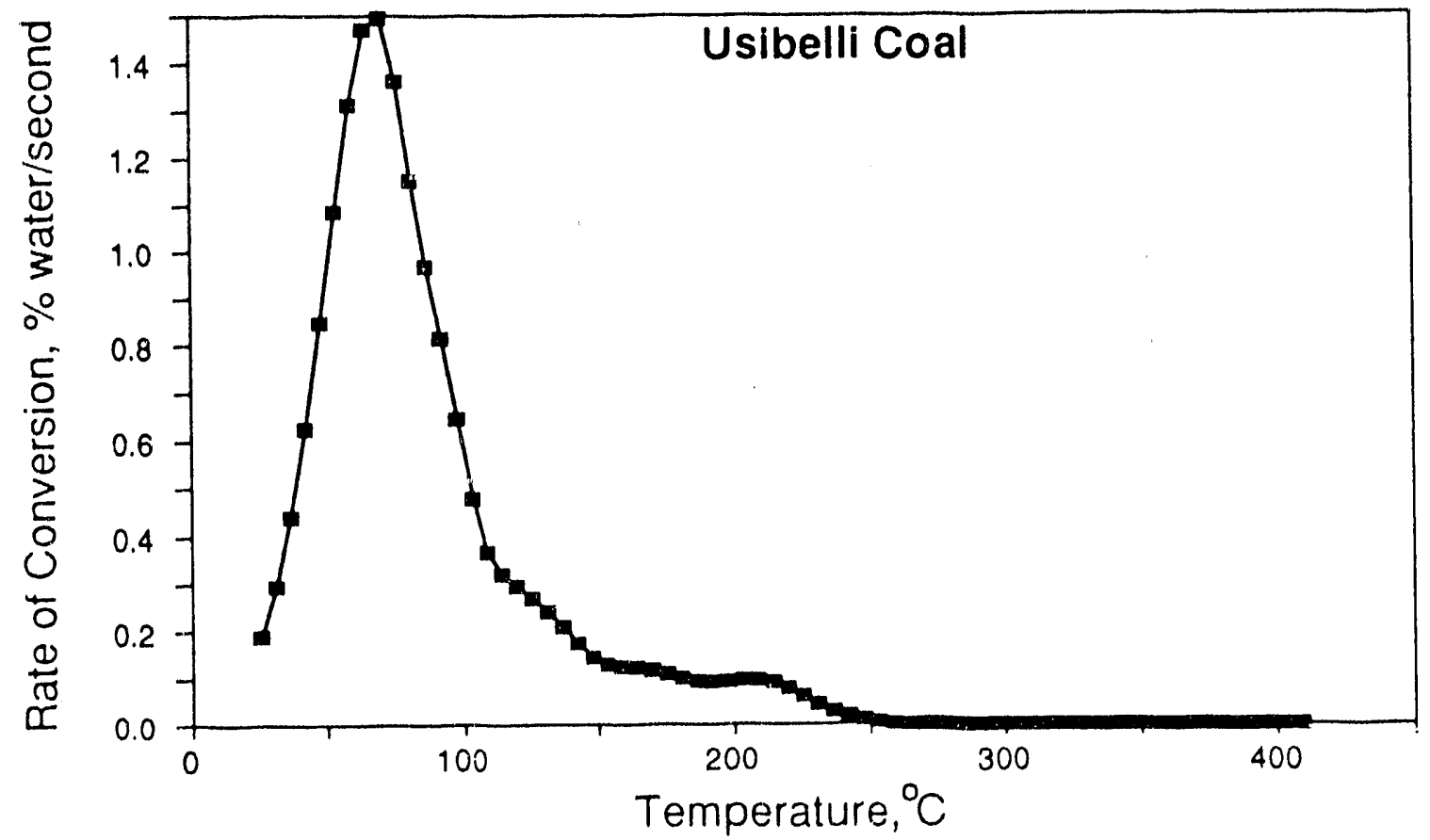

Figure 29. Estimated Rate of Water Evolution for Usibelli Coal at $100^{\circ} \mathrm{F} / \mathrm{min}\left(55.6^{\circ} \mathrm{C} / \mathrm{min}\right)$ 


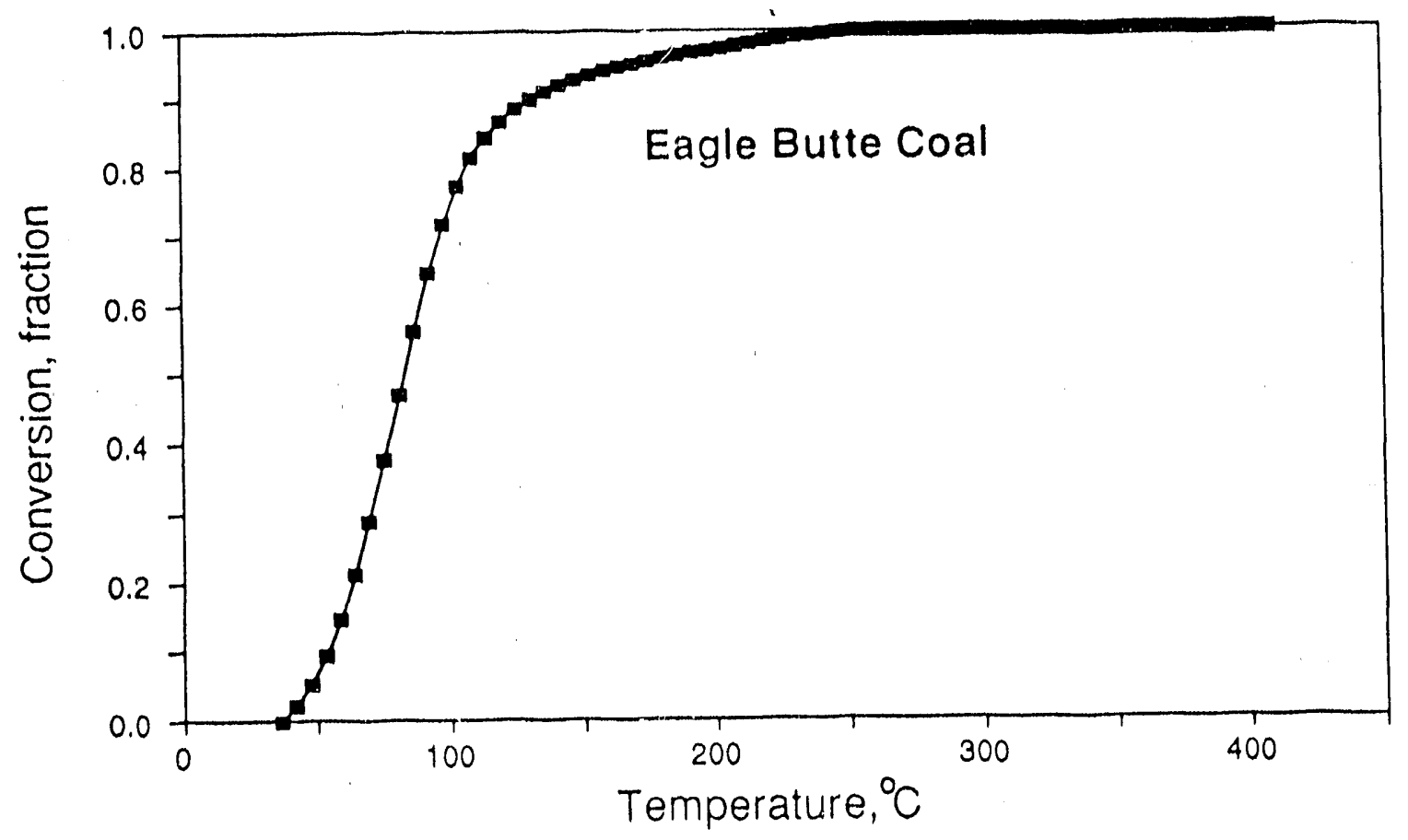

Figure 30. Estimated Cumulative Water Evolution for Eagle Butte Coal at $100^{\circ} \mathrm{F} / \mathrm{min}\left(55.6^{\circ} \mathrm{C} / \mathrm{min}\right)$

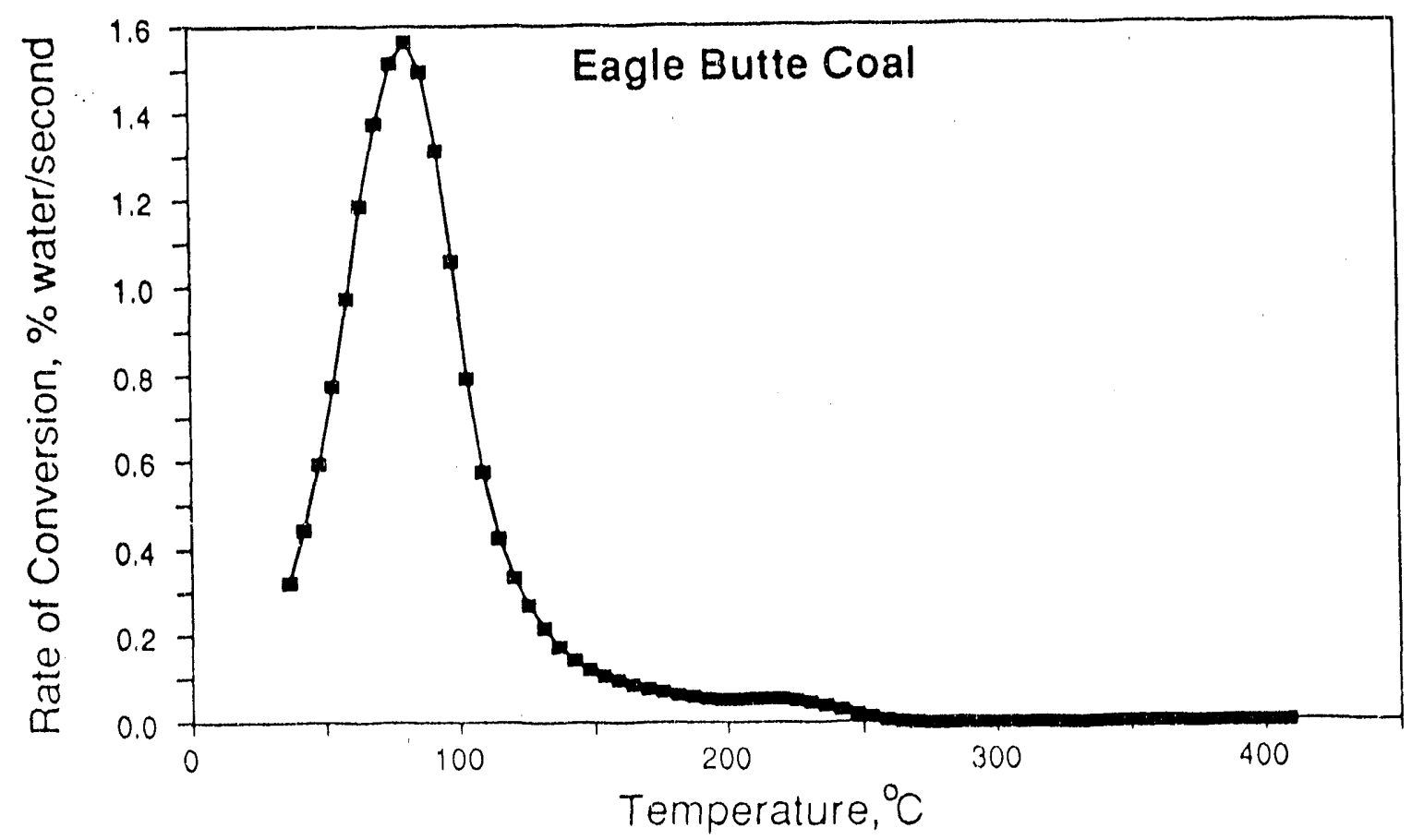

Figure 31. Estimated Rate of Water Evolution for Eagle Butte Coal at $100^{\circ} \mathrm{F} / \mathrm{min}\left(55.6^{\circ} \mathrm{C} / \mathrm{min}\right)$ 


\section{Task 3: Bench-Scale IFB Drying Studies}

Subtask 3.1: Minimum Fluidization Velocity

The pressure drop across the solids bed versis fluidizing gas velocity from the minimum fluidization velocity (MFV) experiments for $-28-m e s h$ crushed feed coal is illustrated in Figures 32 and 33 . Duplicate experiments of MFV determination for each of the crushed feed coals were performed, and the pressure drop data presented is the arithmetic average pressure drop of the two tests for that gas velocity. The average mean deviation of the pressure drop versus gas velocity is 0.62 and 0.26 pounds per square foot (psf) for increasing and decreasing gas velocity MFV tests, respectively, for Eagle Butte coal. The average mean deviation of the pressure drop versus gas velocity data sets is 0.45 and 0.18 psf for increasing and decreasing gas velocity MFV tests, respectively, for Usibelli coal.

The MFV based on increasing fluid velocity for -28 -mesh Eagle Butte coal is approximately $1 \mathrm{ft} / \mathrm{min}$ (Figure 32) and the MFV based on increading fluid velocity for -28 -mesh Usibelli coal is approximately 3 ft/min (Figure 33). The pressure drop across the solids bed at the MFV is approximately 25 psf per foot for the Eagle Butte feed coal (Figure 32) and 31 psf per foot for the Usibelli feed coal (Figure 33). Some particle entrainment occurred at the onset of fluidization in both coals. In addition, the behavior of the crushed Eagle Butte coal indicates some degree of slugging of the bed and gas flow channeling (Figure 32). 


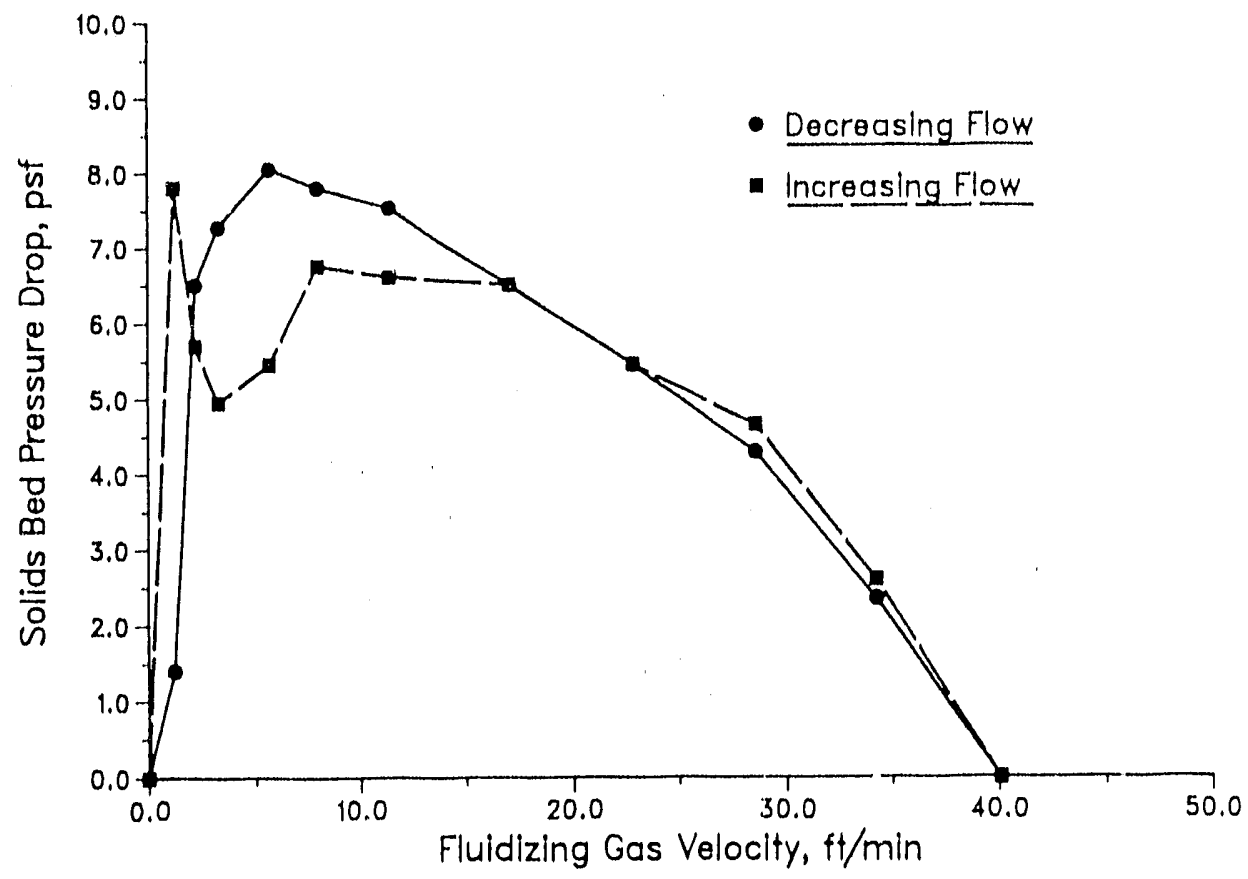

Figure 32. MFV Result for Eagle Butte Coal (4-inch bed of -28-mesh particles)

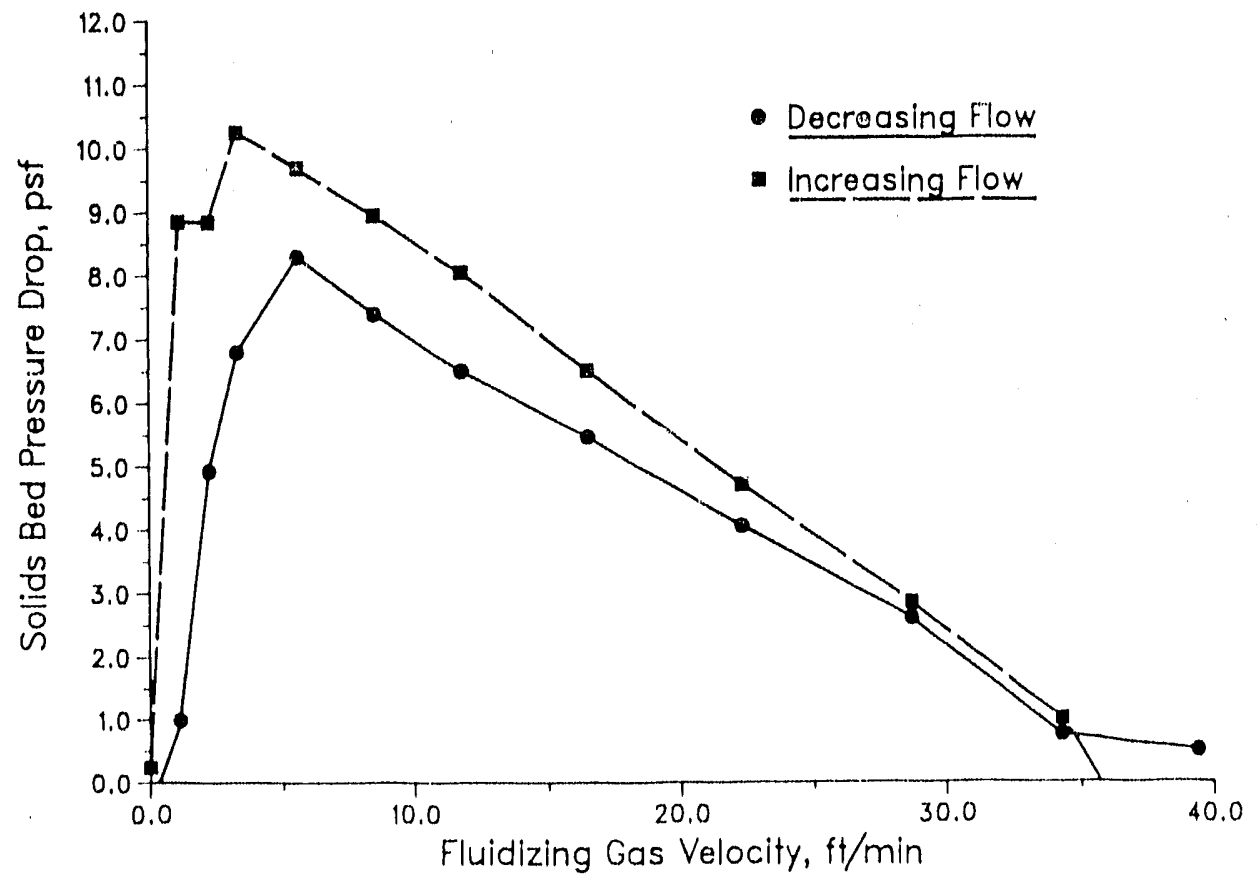

Figure 33. MFV Result for Usibelii Coal

(4-inch bed of -28-mesh particles) 
A significant volume of material was entrained in the increasing flow portion of the Usibelil coal test (Figure 33). This is apparent from the offget of the increasing and decreasing flow curves over the entire velocity range.

The results of the initial IFB cold flow reactor tests indicate that worizontal solids transport in the reactor occurs even at low reactor slopes and low gas-to-solids ratios. However, IFB operation at these conditions results in the creation of a static bed in the feed end of the reactor, batch fluidization in the center of the reactor, and continuous fluidization at the discharge end of the reactor. Increasing the reactor slope under these operating conditions decreases sizes of the static bed and batch fluidization zones. If the IFB slope is increased sufficiently, an even fluidized bed through the entire length of the reactor results.

The solids bed geometry of Eagle Butte coal (Figure 34) was different from that of Usibelii coal (Figure 35) under similar conditions. The geometry of the static zone created using crushed Eagle Butte coal was not as high and was longer than the static zone created using Usibelli coal under similar conditions. However, the effect of increasing IFB reactor slope was similar with both coals. Increased reactor slope tended to reciuce the volume of the static zone and to increase the volume of the fluidired zone. 

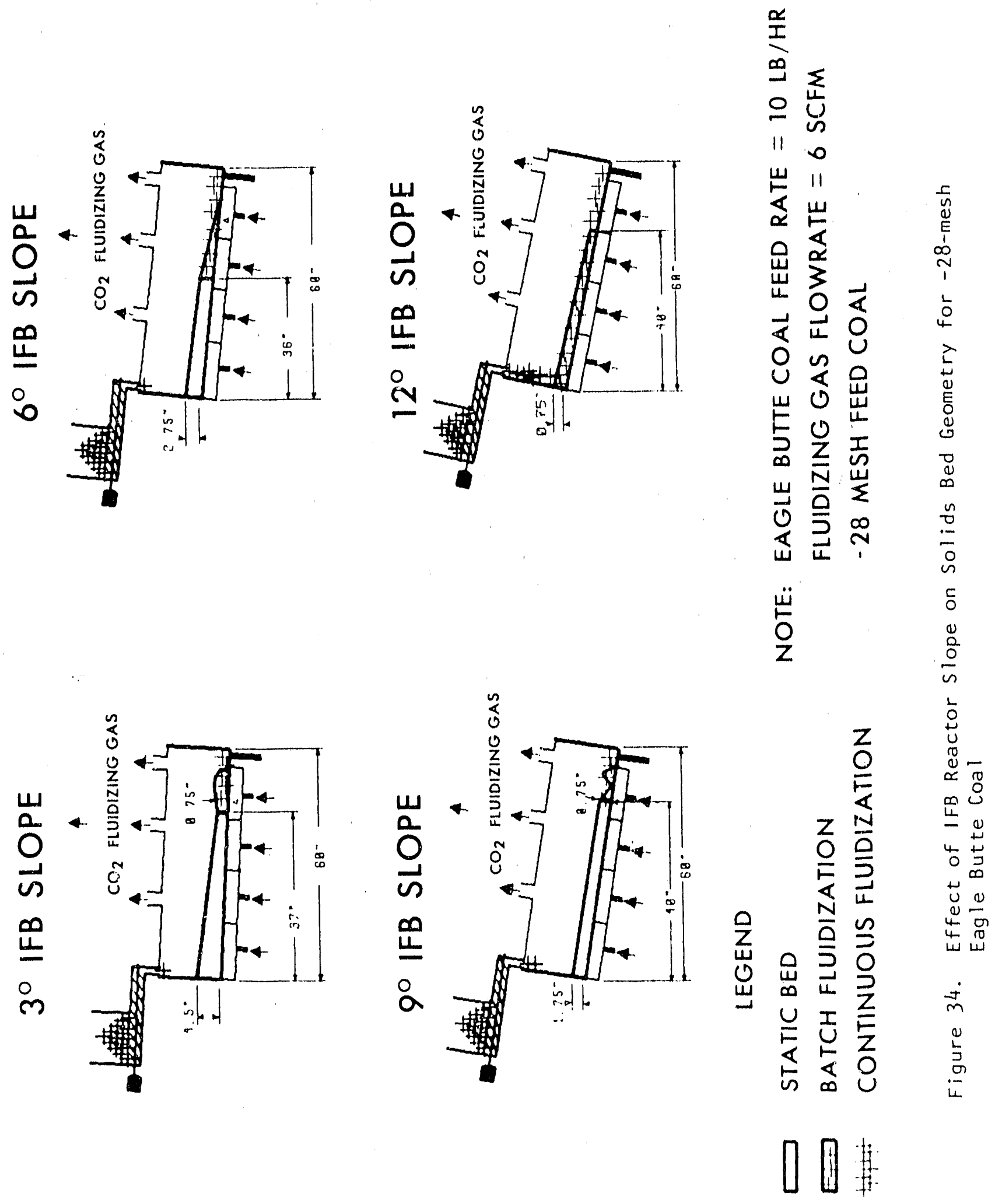

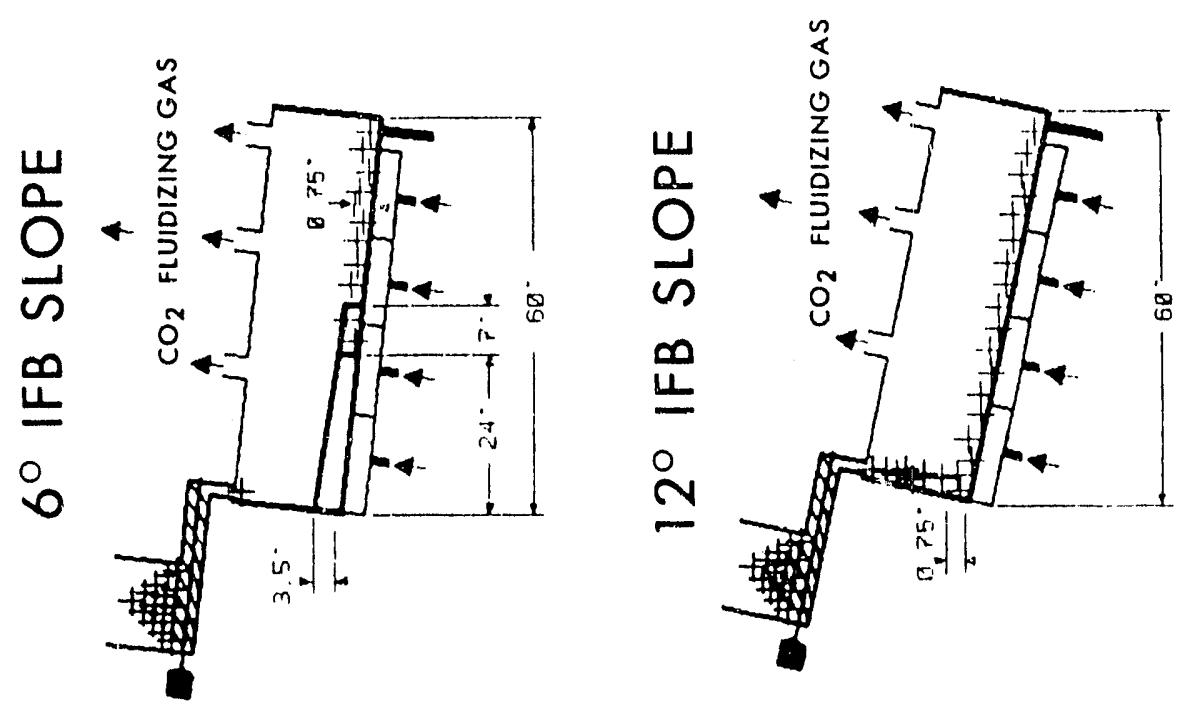

$\begin{array}{ll}\stackrel{\sum}{x} & \underline{u} \\ 0 & u \\ 0 & 0 \\ 0 & 11\end{array}$

11

祭

ख)

岃出 0

倇芯出

OU U

寻

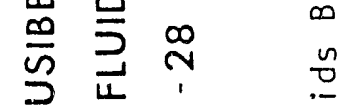

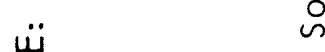

$\stackrel{5}{\mathrm{O}}$

ธ
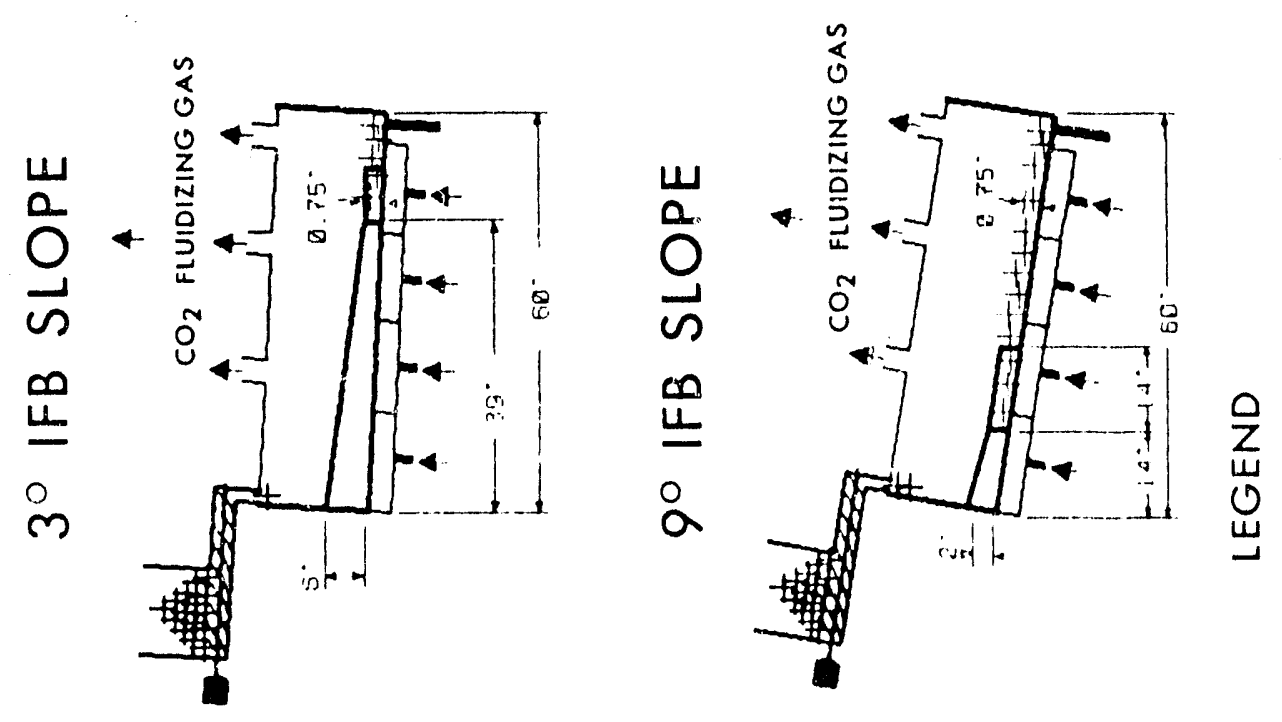

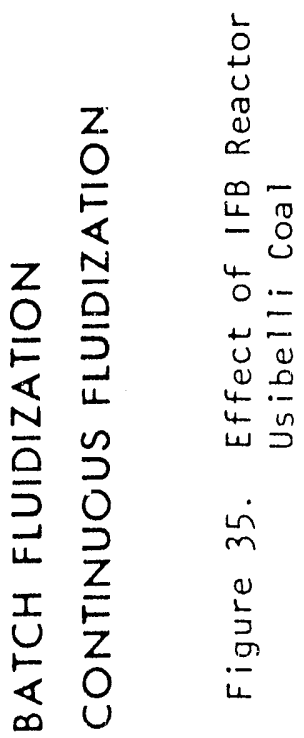

0. 
As coal is fed into the IFB reactor, it tends to create a bed of solids near the solids inlet. The one fluidizing gas inlet to the fluidizing gas distributor in the bench-scale IFB is located near the solids inlet and feeds the entire length of the reactor. The ariations in the depth of the solids bed through the length of the reactor and the fact that the fluidizing gas distributor has only one inlet facilitate an uneven fiow distribution with respect to the reactor length. Thus, at low gas-tosolids ratios and small reactor slopes, the fluidizing gas velocity increases through the length of the IFB reactor. The fluidizing gas velocity is lowest near the reactor inlet and greatest near the reactor outlet. Figure 36 relates the MFV data and the cold flow data This diagram is a graphical representation from the literature of the log of pressure drop across the solids bed versus the log of the superficial gas velocity (McCabe and Smith 1967).

Eurther understanding of the behavior of gases and solids flowing through the IFB is critical to understanding the behavior of the IFB drying process. Horizontal transport of coal and vertical transport of entrained coal occur simultaneously in the IFB. Horizontal coal transport occurs as a result of flow conditions in the lower portion of the reactor where the reactor cross-sectional area is minimum while vertical coal transport occurs as a result of flow conditions in the upper portion of the lFB where the reactor cross-section is marimum. 


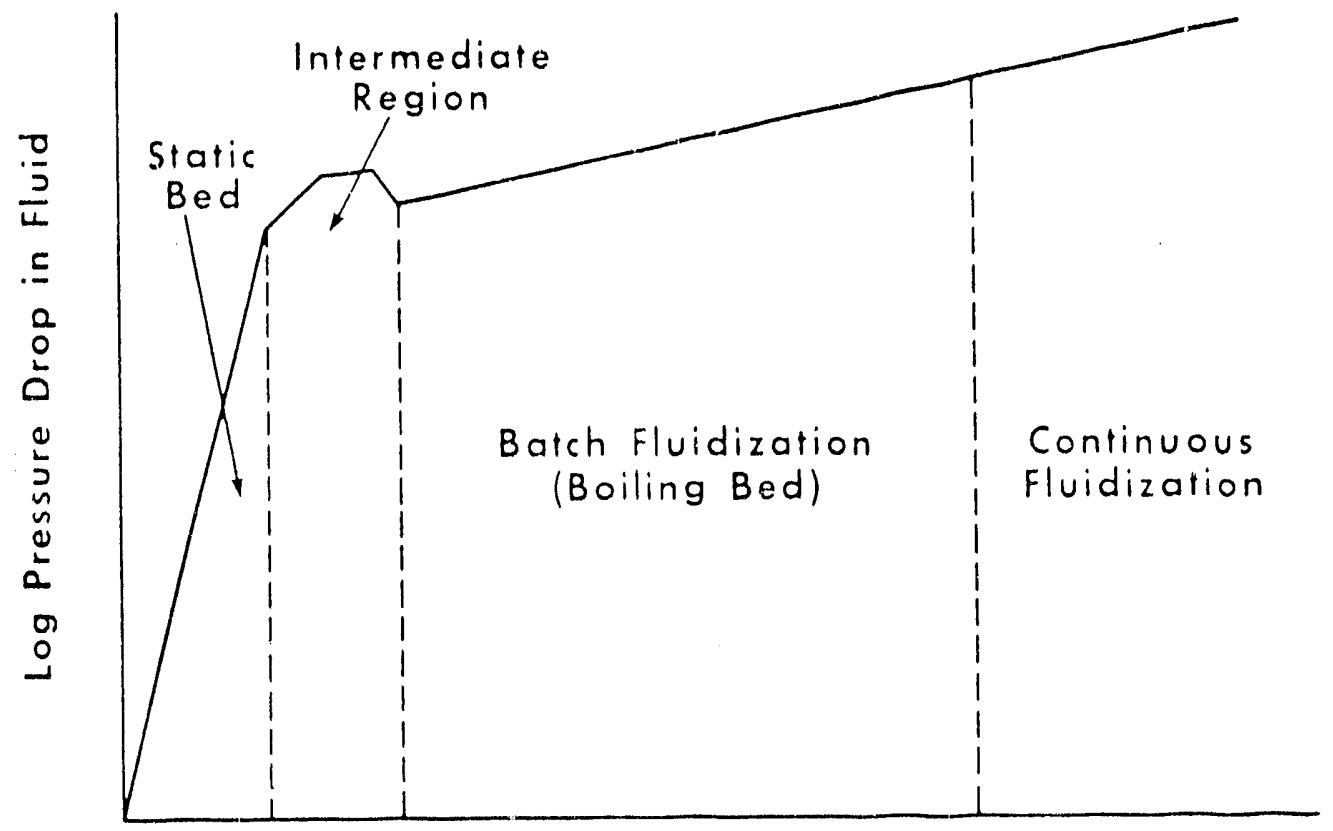

Log Superficial Fluid Velocity

Figure 36. Pressure Drop in Fluidized Solids

(from Mccabe and Smith 1967)

The gas velocity flowing through the coal bed is maximum with respect to the vertical axis because the cross-sectional area of the IFB is smallest at the coal bed located in the bottom of the reactor. The gas velocity flowing through the disengagement zone near the top of the reactor is minimum with respect to the vertical axis because the IFB crosssectional area is largest at the disengagement zone.

The horizontal velocity gradient found to exist in the gas flowing through the coal bed in the IFE will affect the horizontal transport of the non-entrained coal. The coal will tend to move fastest in the horizontal direction where the gas velocity flowing through the coal bed is the gre iest. However, since the actual coal iesidence time is the sum of the coal residence times in each of the velocity regimes, the total coal 
residence time can be correlated with the average vertical velocity of gas flowing through the coal bed.

A horizontal gas velocity gradient near the top of the IFB would affect the transport of entrained coal. Gas flowing through the disengagement zone near the top of the reactor would have a near uniform velocity profile because the outlet header is sized to provide equal flow restriction at each outlet. The amount of gas flowing out of each outlet is dependent upon the pressure drop from the upper portion of the IFB to the gas outlet header and upon the restriction to flow of the outlet piping to the header. Since the flow restrictions of the piping from each outlet to the header are identical and nothing exists in the upper portion of the reactor to restrict the horizontal cross-flow of gas, the horizontal velocity gradient in the upper portion of the reactor must be effectively zero. A horizontal pressure gradient would have to exist in the space at the top of the reactor for velocities at each outlet to be different.

In summary, horizontal solids transport in the IFB is related tc the gas flow conditions through the solids bed at the bottom of the reactor. Since the totel residence time of the solids transported horizontally through the reactor is the sum of the residence times of the solids in each velocity regime, the total residence time may be related to the average vertical velocity of the gas flowing through the solids bed. The vertical transport of entrained solids is related to the marimum vertical velocity of gases flowing through the disengagernent zone. The design of the IFB reactor is such that the vertical gas velocity through the disengagement zone is nearly uniform. 
Correlations of both cold-flow and bench-scale IFB erperimental data were performed based upon the flow conditions at the bottom of the IFB and in the disengagement zone. The flow conditions at the bottom of the IFB were used to calculate the gas velocity for the holizontal transport of solids. The gas velocity used in the corelation for the solid entrainment was calculated based on the flow conditions in the disengagement zone.

Another series of IFB cold-flow experiments were performed to determine the relationship of the solids residence time to the gas-flow conditions in the IFB. This series of cold-flow experiments consisted of a total of 32 tests. Each feed coal was tested using four different fluidizing gas flow rates and using four different IFB reactor slopes. In all cases, carbon diotide fluidizing gas flowrates of $1.5,3.1,5.4$, and 7.8 scfm were used for each reactor slope. IFB reactor slopes of 3, 6, 9, and 12 degrees were tested using crushed Eagle Butte feed coal and IFB reactor slopes of 6 , 9 , 12, and 15 degrees were tested using crushed usibelil feed coal. The preliminary results of the 3 degree IFB slope uging Eagle Butte feed coal indicated that cold fluidizing gas flowrates of 5.4 scfm were required to prevent the cold flow reactor from plugging. An IFB slops of 3 degrees was not tested using Usibelid foed coal. Instedd, the is degree IFB slope teste using reiteliz feed coal replaced the 3 degres alope testo.

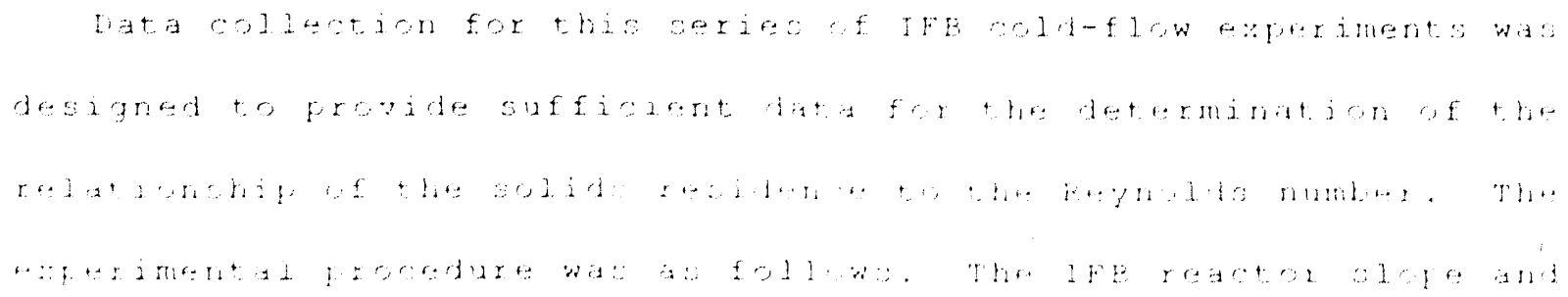


fluidizing gas flowrate were fixed and recorded at the beginning of each experiment along with the tare weight of the empty IFB cold-flow reactor. A known mass of feed coal was introduced into the feed hopper and the feed was started. The mass of feed, feeder setting, and the time feed was initiated, were recorded. Observations regarding the development of the solids bed in the IFB were also recorded. When the solids bed was developed and stable, a dimensioned sketch of the bed geometry was recorded. This description included the si:e and location of the static, batch fluidization, continuous fluidization zones of the solids bed. Coal feed continued until the feeder was emptied and shut off. Fluidizing gas flow was also shut off immediately after the feeder was emptied. The time the feed was shut off was recorded. The IFB reactor was then disassembled and weighed as was the product collection can.

The average solids residence time was determined using a method provided in the literature (Kunii and Levenspiel. 1969). This method describes the solids residence time as:

Average Solids Residence Time $=\frac{\text { Mass of reactor solids bed }}{\text { Feed rate - Entrainment rate }}$

The mass of the reactor solids bed was considered to be only the mass of the active bed in the reactor for these calculations. This was calculated by gubtracting the estimated mas of the static lat in the radotor from the total mass of oolids in the lFB oold-flow redot it the 


\begin{abstract}
time of shut-down. The volume of the static bed in the IFB was calculated from the description of the bed geometry provided for each test. The bulk density and porosity of the crushed feed coals were experimentally determined to be $67 \mathrm{lb} / \mathrm{ft}^{3}$ and $35.5 \%$ for the crushed Eagle Butte feed coal. and $68 \mathrm{Lb} / \mathrm{ft}^{3}$ and $33 \%$ for the crushed Usibelli feed coal. The mass of material in the static bed was then determined from the static bed volume by assuming the static bed to be a packed bed and using the bulk density and porosity previously determined.
\end{abstract}

The coal feed rate was determined as the amount of coal introduced into the reactor divided by the time the feeder was in operation. The entrainment rate was determined as the percentage of the coal. fed. The mass of material entrained was calculated as the mass of coal fed to the reactor minus the sum of the mass of product collected and the total mass in the reactor at shutdown.

The solids Reynolds number of the fluidized particles is defined by the following equation:

$$
\mathrm{N}_{\mathrm{Re}}=\underline{\mathrm{D}}_{\mathrm{s}}-\underline{\mathrm{V}}_{\mathrm{g}} \rho_{\mathrm{g}} \rho_{\mathrm{s}}
$$

where:

$$
\begin{aligned}
& N_{R e}=\text { solids reynolds numoer } \\
& V_{g}=\text { gas velocity } \\
& D_{S}=\text { average diameter of solid particles } \\
& \rho_{S}=\text { solid particle density } \\
& \mu_{g}=\text { gas viscosity }
\end{aligned}
$$


The solids Reynolds number was determined for each fluidizing gas flowrate by using the average diameter of the feed coal as determined from wet screen analysis, the average density of the solid particles, and the carbon dioxide fluidizing gas flowrate and gas properties assuming a $60^{\circ} \mathrm{F}$ $\left(16^{\circ} \mathrm{C}\right)$ inlet temperature and atmospheric pressure. In Laramie, Wyoming atmospheric pressure is 11.2 psia.

The results of the cold-flow experiments are summarized in Table 5 . The coal flow rate, IFB reactor slope, solids Reynolds number, entrainment rate expressed as a percentage of the coal feed, total mass of solids in the IFB cold flow reactor, estimated static bed, and average solids residence time are provided in the table for each cold-flow experiment. 
Table 5. Sumary of IFB Cold Flow Test Results

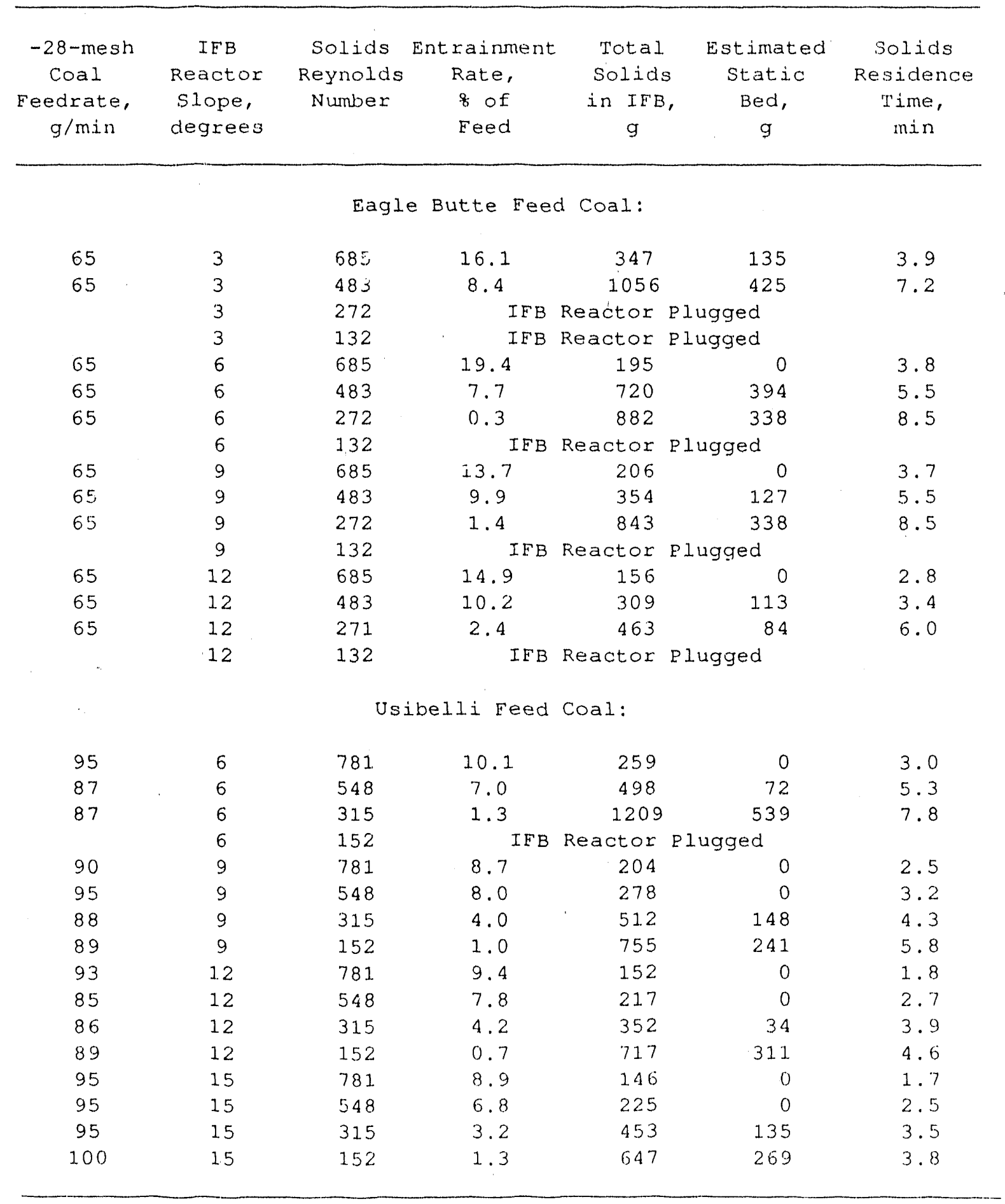


Figure 37 shows the relationship of the average solids residence time to the solids Reynolds number for each of the four IFB slopes tested using Eagle Butte coal. Figure 38 illustrates the relationship of the average solids residence time to the solids Reynolds number for each of the four IFB slopes tested using Usibelil coal.

A simple theoretical analysis of the behavior of the relation the residence time to the Reynolds number indicates that the shape of these curves should be hyperbolic for a constant IfB reactor slope. Consider that as the fluidizing gas velocity approaches zero, the solids Reynolds number approaches zero. As the fluidizing gas velocity approaches zero, the solids cease to be transported and the solids residence time approaches infinity in a sharp asymptotic fashion. Similarly, as the fluidizing gas velocity approaches infinity, the solids Reynolds number also approaches infinity and the solids residence time asymptotically approaches zero. Thus, the hyperbolic shape of these curves is expected. This analysis is subject to two constraints: 1) The slope of the IFB reactor must be less than the angle of repose of the solid material in the IFB or the material will flow without the help of Eluidizing gas and 2) the fluidizing gas velocity must not be sufficiently high to entrain 1008 of the solid material fed to the reactor. The general shapes of the curves shown in Figures 37 and 38 are hyperbolic as theory suggests. Further, the solids residence time decreases with decreasing IFB reactor slope when other conditions remain constant.

\footnotetext{
since these data are correlated non-rimensionally usind the soldids Peynolds number, which is the ratio t inertia to viscous forotes of the
} 
solid particles, the relationships illugtrated in Figures 37 and 38 should be similar for both coals. Figures 39, 40, and 41 provide the comparison of the average solids residence time versus the solids Reyrolds number for each of the three IFB reactor slopes tested using both feed coals (6, 9, and 12 degrees). The agreement of these data is reasonable although there is a slight differences between the coals. The differences in the data are probably due to the tendency of the Eagle Butte coal to stick together and form aggregates of a larger particle diameter. The reasonable agreement of these data demonstrate that this dimensionless method will allow one to estimate with reasonable accuracy the average solids residence time of another coal crushed similarly. 


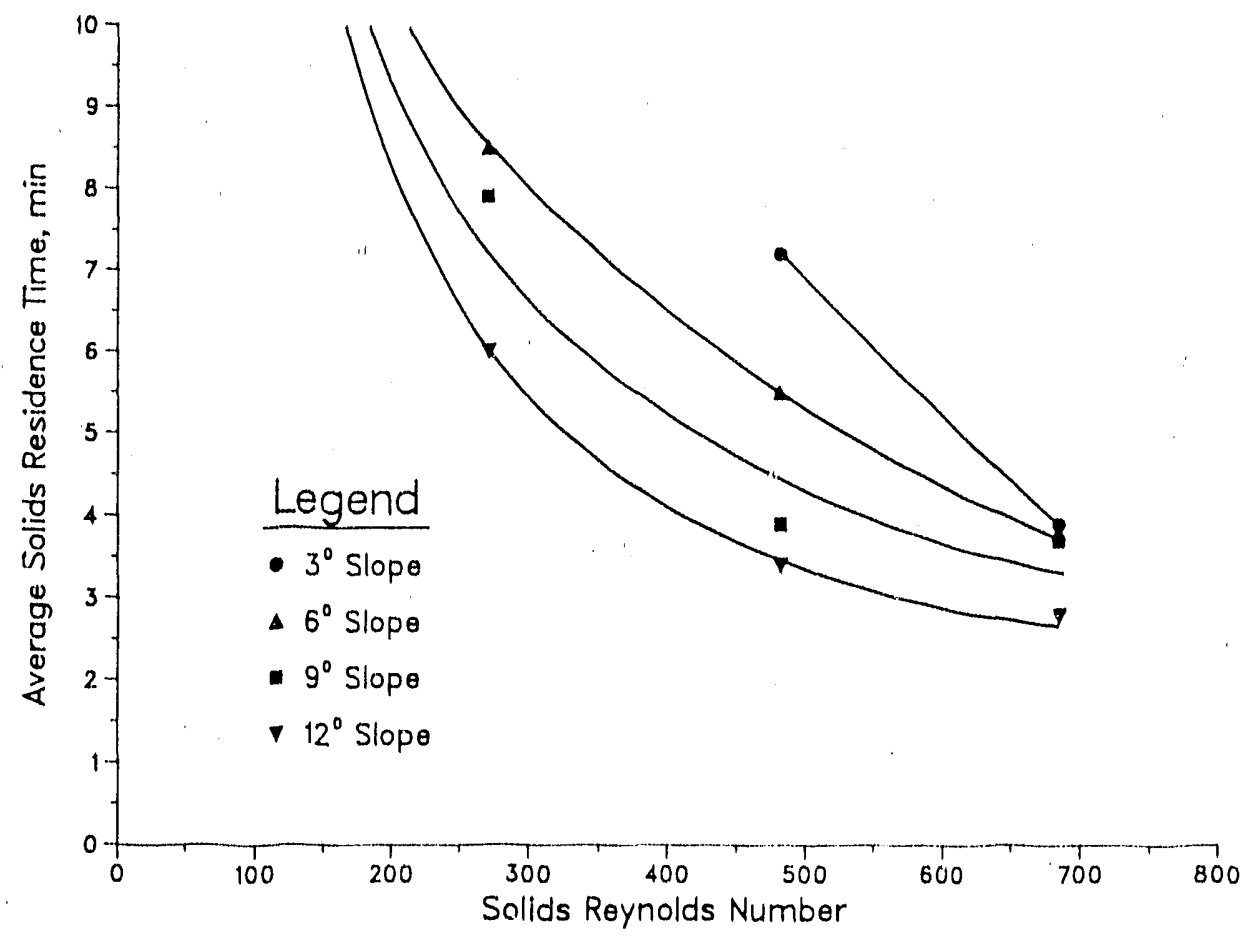

Figure 37. Average Solids Residence Time versus Solids Reynolds Number for Eagle Butte Coal

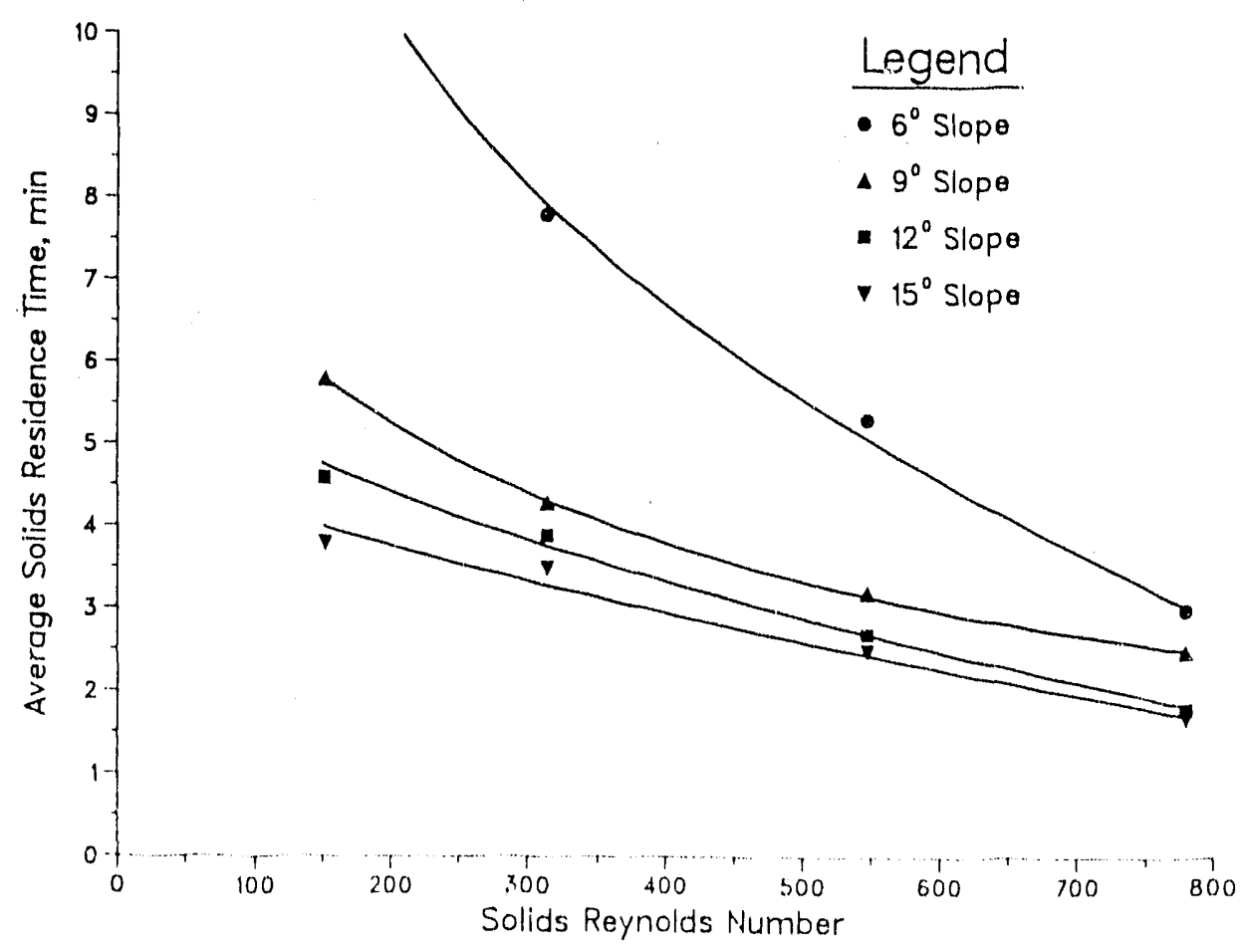

Figure 38. Average Solids Residence Time versus Solids Reynolds Number for Usibelli Coal 


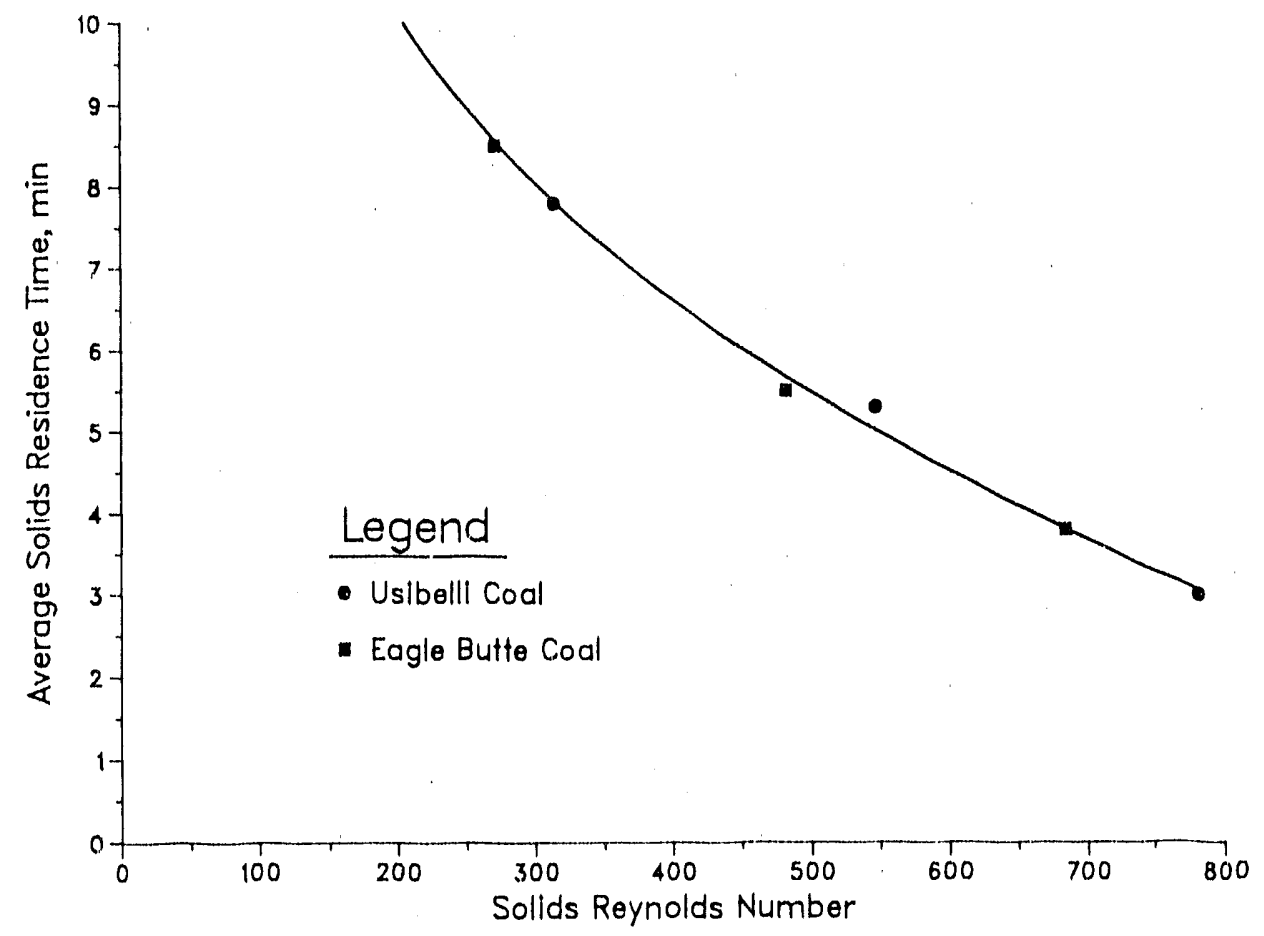

Figure 39. Average Solids Residence Time versus Solids Reynolds Number for a 60 IFB Reactor Slope

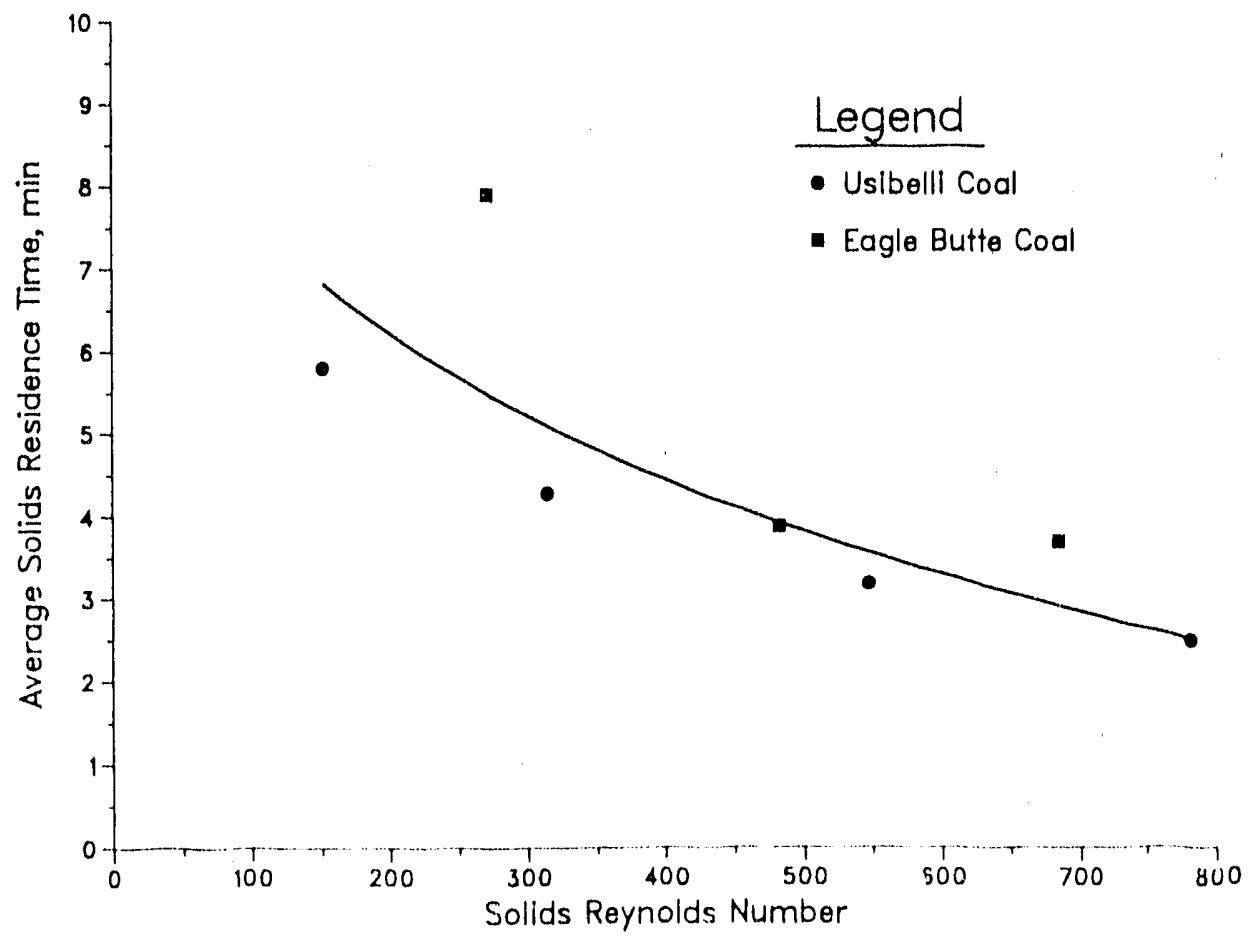

Figure 40. Average Solids Residence Time versus Solids Reynolds Number for a $9^{\circ}$ IFB Reactor Slope 


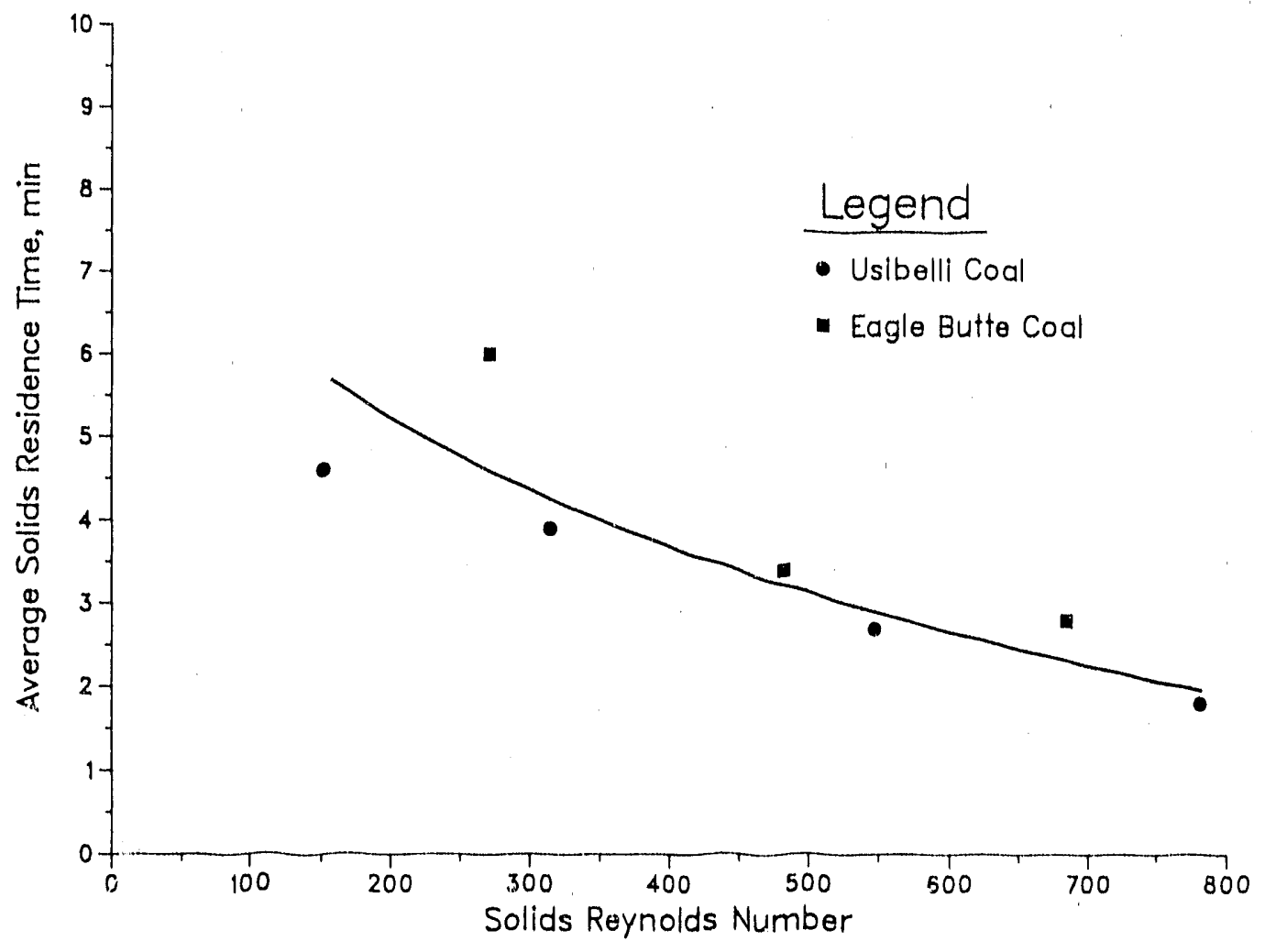

Figure 41. Average Solids Residence Time versus Solids Reynolds Number for a $12^{\circ}$ IFB Reactor Slope 
Subtask 3.2 Drying Tests in an IFB Dryer

A total of forty-one 4 -hour $(19$ using Eagle Butte coal including shakedown test and 22 using Usibelli coal) and eight 12-hour (4 using each coal) bench-sca' IFB drying tests were conducted. IFB rea tor slopes of $3,6,9,12$, and 15 degrees were investigated for each coal.

Experimental conditions, product moisture content, and product heating values for the 4-hour and 12-hour tests using Eagle Butte coal are listed in Table 6. During the tests using Eagle Butte feed coal, gas-to-solids ratios ranging from approximately 0.7 to $5.5 \mathrm{lb} / \mathrm{lb}(\mathrm{kg} / \mathrm{kg})$ and average IFB reactor temperatures ranging from approximately 370 to $730^{\circ} \mathrm{F}\left(188^{\circ}\right.$ to $\left.388^{\circ} \mathrm{C}\right)$ were tesied. In all of these experiments the dried coal product contained less than 1.3 moisture determinew by proximate analysis. The heating values of the products were elevated to a range of 11,200 to $12,800 \mathrm{Btu} / \mathrm{lb}$ from 8,470 Btu/lb.

Experimental conditions, product moisture content, and product heating values for the 4-hour and 12-hour tests using Usibelli coal are listed in Table 7. During the tests using Usibe? i feed coal, gas-to-solids ratios ranging from approximately 0.7 to $4.0 \mathrm{lb} / \mathrm{lb}(\mathrm{kg} / \mathrm{kg})$ and average IFB reactor temperatures ranging from approximately 360 to $750^{\circ} \mathrm{F}\left(182\right.$ to $\left.399^{\circ} \mathrm{C}\right)$ were tested. In $a^{*}$ of these experiments the dried coal roduct containisd less than 1.28 moisture. The heating values of these products were elevated to a range of 10,180 to 11,520 Btu/lb from $8,470 \mathrm{Btu} / 1 \mathrm{~b}$. 
Table 6. Summary of Experimental Conditions for IFB Bench-Scale Drying Tests using Eagle Butte Coal

\begin{tabular}{|c|c|c|c|c|}
\hline $\begin{array}{l}\text { Reactor } \\
\text { Slope, } \\
\text { degrees }\end{array}$ & $\begin{array}{l}\text { Ratio of } \\
\text { Gas to } \\
\text { Solids, } \\
\text { lb/lb }\end{array}$ & $\begin{array}{c}\text { Aver: } \\
\text { Dryer } \\
\text { Tumperature, } \\
\text { 'F }\end{array}$ & $\begin{array}{c}\text { Product } \\
\text { Moisture, } \\
\&\end{array}$ & $\begin{array}{c}\text { Product } \\
\text { HHV, } \\
\text { Btu/Ib }\end{array}$ \\
\hline 3 & 5.5 & 59.5 & 0.0 & 12,250 \\
\hline 3 & 4.9 & 589 & 0.1 & 12,230 \\
\hline 3 & 2.7 & 531 & 0.0 & 12,220 \\
\hline $3^{a}$ & 3.9 & 695 & 0.0 & 12,440 \\
\hline 6 & 2.7 & 595 & 0.2 & 12,250 \\
\hline 6 & 4.0 & 599 & 0.1 & 12,320 \\
\hline 6 & 4.1 & 623 & 0.0 & 12,320 \\
\hline 6 & 2.5 & 666 & 0.0 & 12,040 \\
\hline $6^{a}$ & 3.0 & 684 & 0.2 & 11,870 \\
\hline 9 & 4.6 & 617 & 0.0 & 12,050 \\
\hline 9 & 3.6 & 589 & 0.1 & 12,800 \\
\hline 9 & 2.3 & 588 & 0.0 & 11,970 \\
\hline 9 & 4.8 & 692 & 0.0 & 12,560 \\
\hline 9 & 3.1 & 693 & 0.0 & 12,190 \\
\hline $9^{a}$ & 1.5 & 611 & 0.0 & 11,940 \\
\hline 12 & 1.4 & 603 & -- & $\ldots \ldots$ \\
\hline 12 & 1.3 & 649 & 1.3 & 11,470 \\
\hline 12 & 2.3 & 682 & 0.0 & 11,690 \\
\hline 15 & 1.4 & 645 & 0.1 & 11,506 \\
\hline 15 & 1.4 & 377 & 0.2 & 11,200 \\
\hline 15 & 0.7 & 589 & -- & 11,340 \\
\hline $15^{a}$ & 1.4 & 731 & 0.3 & $\cdots \cdots$ \\
\hline
\end{tabular}

a 12-hr test 
Table 7. Summary of Experimental Conditions for IFB Bench-Scale nrying Tests using Usibelli Coal

\begin{tabular}{|c|c|c|c|c|}
\hline $\begin{array}{l}\text { Reactor } \\
\text { Slope, } \\
\text { degrees }\end{array}$ & $\begin{array}{l}\text { Ratio of } \\
\text { Gas to } \\
\text { Solids, } \\
\text { lb/lb }\end{array}$ & $\begin{array}{c}\text { Average } \\
\text { Dryer } \\
\text { Temperature, } \\
{ }^{\circ} \mathrm{E} \text { ' }\end{array}$ & $\begin{array}{c}\text { Product } \\
\text { Moisture, } \\
\end{array}$ & $\begin{array}{c}\text { Product } \\
\text { HHV, } \\
\text { Btu'lb }\end{array}$ \\
\hline 3 & 2.6 & 494 & 1.2 & 10,450 \\
\hline 3 & 3.4 & 705 & 0.0 & 11,380 \\
\hline 3 & 3.7 & 690 & 0.4 & $-\cdots-\cdots$ \\
\hline$\vdots$ & 3.4 & 605 & 0.1 & $--\cdots--$ \\
\hline $3^{a}$ & 4.0 & 611 & 0.0 & 10,950 \\
\hline 6 & 2.7 & 690 & 0.0 & 10,960 \\
\hline 6 & 2.1 & 675 & 0.0 & 11,120 \\
\hline 6 & 3.3 & 680 & 0.0 & 11,300 \\
\hline 6 & 3.3 & 695 & 0.0 & $1 \therefore .040$ \\
\hline 6 & 2.8 & 564 & 0.0 & 11,000 \\
\hline $6^{a}$ & 2.6 & 664 & 0.3 & 10,560 \\
\hline 9 & 2.6 & 637 & 0.0 & 11,520 \\
\hline 9 & 2.8 & 678 & 0.0 & 11,170 \\
\hline 9 & 2.7 & 595 & 0.1 & 11,110 \\
\hline 9 & 2.7 & 571 & 0.2 & 11,130 \\
\hline 9 & 1.8 & 653 & 0.0 & 11,050 \\
\hline 9 & 1.9 & 603 & 0.1 & 10,830 \\
\hline 9 & 3.8 & 707 & 0.0 & 10,850 \\
\hline $9^{a}$ & 1.9 & 632 & 0.0 & 10,830 \\
\hline 12 & & 632 & 0.1 & $10,0,50$ \\
\hline $\begin{array}{l}12 \\
12\end{array}$ & $\begin{array}{l}1.5 \\
1.3\end{array}$ & $\begin{array}{l}632 \\
653\end{array}$ & 0.1 & 10,540 \\
\hline 12 & 2.3 & 692 & 0.7 & 10,530 \\
\hline 15 & 1.3 & 648 & 0.1. & 10,680 \\
\hline 15 & 1.4 & 364 & 0.7 & 10,180 \\
\hline 15 & 0.7 & 594 & --- & $-\cdots---$ \\
\hline $15^{a}$ & 1.3 & 752 & 0.1 & 10,270 \\
\hline
\end{tabular}

a $12-h=$ test

Waterial balances were performed for each bench-scale eaperiment. Total mass, fixed carbon, and ash balances were caloulatel from pro:imate analyses of the feed coa?, product, and entrained solids. Fro:imate

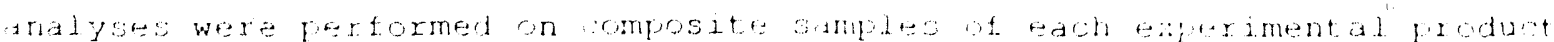
and oomporte amples of solide entrainod from each experiment. 
Proximate analyses of composite feed coal samples were performed for each 12-hour experiment but only proximate moisture analyses of composite feed samples were performed for each 4 -hour experiment.

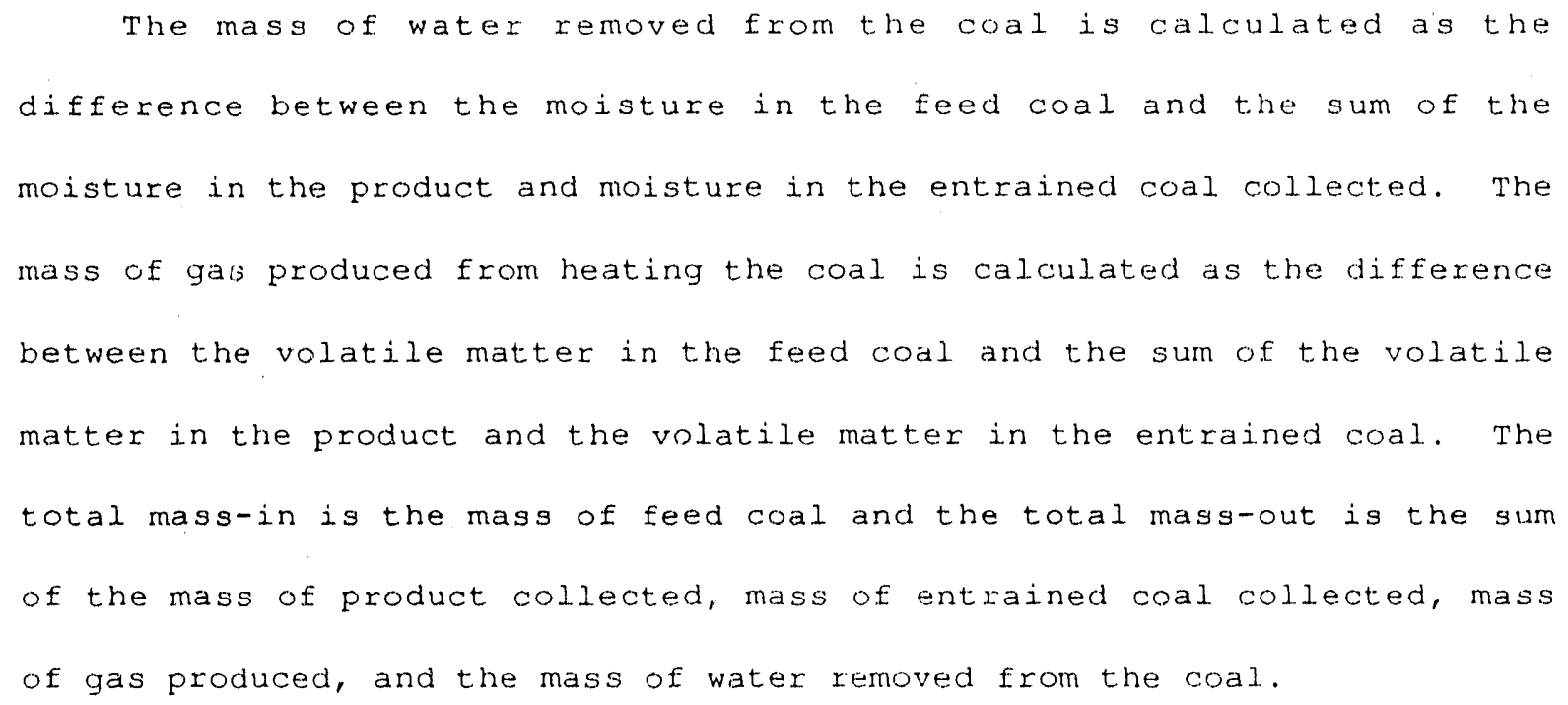

The experimental closures for total mass, fired carbon, and ash balances are presented in Table 8 along with the IFB reactor slope ant gas-to-solids ratio for the bench-scale IFB drying experiments conducted using Eagle Butte coal. The two experiments with a fixed carbon balance closure less than 908 or greater than $110 \%$ are omitted from further analyses. 
Table 8. Sumary of Experimental Balance Closures for IfB Bench-Scale Drying Tests using Eagle Butte Coal

\begin{tabular}{|c|c|c|c|c|c|}
\hline $\begin{array}{l}\text { Reactor } \\
\text { Slope, } \\
\text { degrees }\end{array}$ & $\begin{array}{l}\text { Ratio of } \\
\text { Gas to } \\
\text { Solids, } \\
\text { lb/lb }\end{array}$ & $\begin{array}{c}\text { Average } \\
\text { Dryer } \\
\text { Temperature, } \\
{ }^{\circ} \mathrm{F}\end{array}$ & $\begin{array}{l}\text { Balance } \\
\text { Total } \\
\text { Mass }\end{array}$ & $\begin{array}{l}\text { Closures, of } \\
\text { Fized } \\
\text { Carbon }\end{array}$ & Ash \\
\hline 3 & 5.5 & 595 & 94.3 & 86.7 & 82.0 \\
\hline 3 & 4.9 & 589 & 97.3 & 93.7 & 90.0 \\
\hline 3 & 2.7 & 531 & 99.3 & 98.4 & 96.8 \\
\hline $3^{a}$ & 3.9 & 695 & 37.8 & 95.2 & 88.5 \\
\hline 6 & 2.7 & 535 & 102.2 & 105.6 & 100.4 \\
\hline 6 & 4.0 & 599 & 98.8 & 97.9 & 92.6 \\
\hline 6 & 4.1 & +23 & 102.1 & 105.4 & 100.7 \\
\hline 6 & 2.5 & 1,66 & 97.4 & 94.3 & 89.4 \\
\hline $6^{a}$ & 3.0 & 684 & 97.5 & 94.2 & 92.8 \\
\hline 9 & 4.6 & 617 & 99.7 & 98.7 & 103.2 \\
\hline 9 & 3.6 & 589 & 96.1 & 91.5 & 82.3 \\
\hline 9 & 2.3 & 588 & 97.7 & 95.2 & 88.9 \\
\hline 9 & 4.8 & 692 & 36.2 & 91.9 & 91.1 \\
\hline 9 & 3.1 & 693 & 91.2 & 80.1 & 70.0 \\
\hline $5^{3}$ & 15 & 611 & 98.5 & 96.5 & 94.1 \\
\hline 12 & 1.4 & 603 & 98.7 & 97.0 & 35.8 \\
\hline 12 & $1 \cdot 3$ & 649 & 95.8 & 90.3 & 85.9 \\
\hline 12 & 2.3 & 682 & 97.6 & 94.8 & 89.4 \\
\hline 15 & 1.4 & 645 & 97.5 & 33.9 & 93.5 \\
\hline 15 & 1.4 & 377 & 38.5 & 96.5 & 96.9 \\
\hline 15 & 0.7 & 583 & $\cdots-$ & ---- & --- \\
\hline $15^{\mathrm{a}}$ & 1.4 & 731 & 37.0 & 92.3 & 98.6 \\
\hline
\end{tabular}

a Experiment of nominally 12 -hr duration

Similarly, the experimental closures for total mass, fiaed carbon, and ash balances are presented in Table 9 along with the IfB reactor slope and gas-to-solids ratio for the bench-scale IFE dryirg axperiments conducted using usibelil feed coal. The four experiments with a fined carl on ralance closure less than 30 f or gredter thar 110 are mited from furtier analyses. 
Table 9. Summary of Experimental Balance Closures for IFB Bench-Scale Drying Tests using Usibelli Coal

\begin{tabular}{|c|c|c|c|c|c|}
\hline $\begin{array}{l}\text { Reactor } \\
\text { Slope, } \\
\text { degrees }\end{array}$ & $\begin{array}{l}\text { Ratio of } \\
\text { Gab to } \\
\text { Solids, } \\
1 b / 1 b\end{array}$ & $\begin{array}{c}\text { Average } \\
\text { Dryer } \\
\text { Temperature, } \\
{ }^{\circ} \mathrm{F}\end{array}$ & $\begin{array}{l}\text { Balance } \\
\text { Total } \\
\text { Mass }\end{array}$ & $\begin{array}{l}\text { Closures, } \\
\text { Fixed } \\
\text { Carbon }\end{array}$ & Ash \\
\hline 3 & 2.6 & 494 & 100.4 & 100.1 & 100.4 \\
\hline 3 & 3.4 & 705 & 97.6 & 93.9 & 97.5 \\
\hline 3 & 3.7 & 690 & 97.1 & 92.2 & 98.7 \\
\hline 3 & 3.4 & 605 & 99.0 & 96.2 & 103.7 \\
\hline $3^{a}$ & 4.0 & 611 & 98.2 & 97.3 & 91.1 \\
\hline 6 & 2.7 & 690 & 98.1 & 93.7 & 104.2 \\
\hline 6 & 2.1 & 675 & 96.1 & 90.6 & 92.0 \\
\hline 6 & 3.3 & 680 & 105.7 & 113.3 & 114.0 \\
\hline 6 & 3.3 & 695 & 96.6 & 93.1 & 87.6 \\
\hline 6 & 2.8 & 564 & 97.6 & 94.7 & 93.5 \\
\hline $6^{a}$ & 2.6 & 664 & 98.2 & 95.6 & 96.9 \\
\hline 9 & 2.6 & 637 & 97.3 & 94.9 & 87.9 \\
\hline 9 & 2.8 & 678 & 94.7 & 88.6 & 82.9 \\
\hline 9 & 2.7 & 595 & 94.6 & 88.8 & 81.0 \\
\hline 9 & 2.7 & 571 & 98.2 & 97.3 & 89.8 \\
\hline 9 & 1.8 & 653 & 91.6 & 84.0 & 75.3 \\
\hline 9 & 1.9 & 603 & 100.1 & 97.1 & 112.1 \\
\hline 9 & 3.8 & 707 & 97.8 & 92.0 & 106.4 \\
\hline $9^{a}$ & 1.9 & 632 & 99.1 & 100.3 & 90.7 \\
\hline 12 & 1.5 & 632 & 100.4 & 98.9 & 109.5 \\
\hline 12 & 1.3 & 653 & 99.3 & 97.7 & 101.0 \\
\hline 12 & 2.3 & 692 & 96.3 & 91.8 & 90.9 \\
\hline 15 & 1.3 & 648 & 100.9 & 101.1 & 106.4 \\
\hline 15 & 1.4 & 364 & 97.8 & 92.7 & 103.6 \\
\hline 15 & 0.7 & 594 & $\ldots+\cdots$ & --- & --- \\
\hline $15^{a}$ & 1.3 & 752 & 97.3 & 93.3 & 96.5 \\
\hline
\end{tabular}

a $12-h r$ test 
The experimental yields determined from the proximate material balances are presented in Tables 10 and 11 for Eagle Butte and Usibelli coals, respectively. The yield of dry coal product, gas, entrained solids, and water expressed as a percent of the total feed coal are presented for each experiment. Experimental losses can be determined as the difference between 100 and the sum of the yields shown.

In addition, the gas yields as a function of the average IFB dryer temperature are presented in Figures 42 and 43 for Eagle Butte and Usibelii coals, respectively. Similarly, the product compositions as a function of the average IFB dryer temperature are presented in Figures 44 and 45 for Eagle Butte and Usibelli coals, respectively. These figures illustrate the relationship of the volatile matter, fired carbon, and ash contents of the c.y coal. produced to the average IFB dryer temperature for each experiment.

\footnotetext{
Elemental carbon, hydrogen, nitrogen, sulfur, and oxygen balances were performed on a dry ash free (daf) basis for each bench-scale experiment of 12-hour duration. These balances were calculated from proximate balance results, experimental gas composition data, and the results of ultimate analyses of the feeds, products, and entrained coal. The uitimate analysis of the feed coals determined from the data in Table 2 was used for all 12-hr tests because problem. that occurred with the automatic analyzer affected the analytical results of the wet samples.
} 
Table 10. Sumary of Experimental Yields for IFB Bench-Scale Drying Tests using Eagle Butte Coal

\begin{tabular}{|c|c|c|c|c|c|c|}
\hline \multirow{2}{*}{$\begin{array}{l}\text { Reactor } \\
\text { Slope, } \\
\text { degrees }\end{array}$} & \multirow{2}{*}{$\begin{array}{l}\text { Ratio of } \\
\text { Gas to } \\
\text { Solids, } \\
\text { lb/1b }\end{array}$} & \multirow{2}{*}{$\begin{array}{c}\text { Average } \\
\text { Dryer } \\
\text { Temperature, } \\
{ }^{\circ} \mathrm{F}\end{array}$} & \multicolumn{2}{|c|}{ Experimental } & \multirow{2}{*}{$\begin{array}{l}\text { Yield o : } \\
\text { Entrained } \\
\text { Solids }\end{array}$} & \multirow[b]{2}{*}{ Water } \\
\hline & & & Product & Gas & & \\
\hline 3 & 4.9 & 589 & 29.6 & 4.7 & 35.0 & 28.0 \\
\hline 3 & 2.7 & 531 & 57.0 & 2.5 & 11.6 & 28.2 \\
\hline $3^{a}$ & 3.9 & 695 & 36.7 & 8.8 & 28.4 & 28.9 \\
\hline 6 & 2.7 & 595 & 34.0 & 2.2 & 38.5 & 27.2 \\
\hline 6 & 4.0 & 599 & 38.3 & 3.3 & 35.3 & 21.9 \\
\hline 6 & 4.1 & 623 & 58.0 & 2.7 & 20.5 & 20.9 \\
\hline 6 & 2.5 & 666 & 50.7 & 7.5 & 12.3 & 26.9 \\
\hline $6^{a}$ & 3.0 & 684 & 47.9 & 10.1 & 13.4 & 26.1 \\
\hline 9 & 4.6 & 617 & 39.5 & 4.1 & 32.0 & 24.1 \\
\hline 9 & 3.6 & 589 & 47.4 & 5.5 & 16.1 & 27.1 \\
\hline 9 & 2.3 & 588 & 57.0 & 5.8 & 7.7 & 27.2 \\
\hline 9 & 4.8 & 692 & 21.0 & 7.6 & 40.9 & 26.9 \\
\hline $9^{a}$ & 3.5 & 611 & 52.6 & 5.7 & 11.1 & 29.1 \\
\hline 12 & 1.4 & 603 & 55.9 & 3.6 & 13.7 & 25.5 \\
\hline 12 & 1.3 & 649 & 55.9 & 7.1 & 6.7 & 26.1 \\
\hline 12 & 2.3 & 682 & 45.5 & 9.2 & 15.1 & 27.8 \\
\hline 15 & 1.4 & 645 & 55.8 & 4.8 & 9.3 & 27.6 \\
\hline 15 & 1.4 & 377 & 63.6 & 0.9 & 10.1 & 23.9 \\
\hline 15 & 0.7 & 589 & --- & --- & $-\cdots$ & --- \\
\hline $15^{a}$ & 1.4 & 731 & 52.8 & 15.1 & 8.7 & 20.4 \\
\hline
\end{tabular}

a 12 -hr test 
Table 11. Summary of Experimental Yields for IFB Bench-Scale Drying Tests using Usibelli Coal

\begin{tabular}{|c|c|c|c|c|c|c|}
\hline \multirow{2}{*}{$\begin{array}{l}\text { Reactor } \\
\text { Slope, } \\
\text { degrees }\end{array}$} & \multirow{2}{*}{$\begin{array}{l}\text { Ratio of } \\
\text { Gas to } \\
\text { Solids, } \\
\text { 1b/1b }\end{array}$} & \multirow{2}{*}{$\begin{array}{c}\text { Average } \\
\text { Dryer } \\
\text { Temperature, } \\
\text { 'F }\end{array}$} & \multicolumn{3}{|c|}{ Experimental Yield } & \multirow[b]{2}{*}{ water } \\
\hline & & & Product & Gas & $\begin{array}{c}\text { Entrained } \\
\text { Solids }\end{array}$ & \\
\hline \multicolumn{7}{|c|}{ 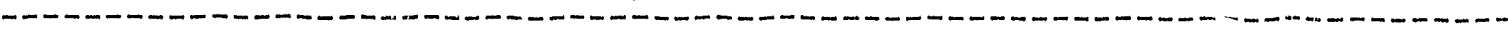 } \\
\hline 3 & 2.6 & 494 & 70.9 & 6.9 & 9.3 & 13.4 \\
\hline 3 & 3.4 & 705 & 50.6 & 15.0 & 14.9 & 17.2 \\
\hline 3 & 3.7 & 690 & 33.1 & 14.8 & 31.3 & 18.1 \\
\hline 3 & 3.4 & 605 & 49.7 & 10.6 & 20.1 & 18.7 \\
\hline $3^{a}$ & 4.0 & 611 & 54.2 & 8.3 & 15.3 & 20.5 \\
\hline 6 & 2.7 & 690 & 53.9 & 13.3 & 13.6 & 17.3 \\
\hline 6 & 2.1 & 675 & 52.8 & 17.2 & 6.2 & 20.0 \\
\hline 6 & 3.3 & 695 & 56.0 & 14.0 & 7.0 & 19.6 \\
\hline 6 & 2.8 & 564 & 64.9 & 5.9 & 8.0 & 1.8 .8 \\
\hline $6^{a}$ & 2.6 & 664 & 55.9 & 13.9 & 11.8 & 16.6 \\
\hline 9 & 2.6 & 637 & 55.7 & 9.2 & 10.4 & 22.1 \\
\hline 9 & 2.7 & 571 & 43.9 & 6.6 & 27.7 & 20.0 \\
\hline 9 & 1.9 & 603 & 64.9 & 8.0 & 5.4 & 21.7 \\
\hline 9 & 3.8 & 707 & 44.1 & 12.8 & 22.3 & 18.6 \\
\hline $9^{a}$ & 1.9 & 632 & 60.9 & 10.2 & 10.2 & 17.8 \\
\hline 12 & 1.5 & 632 & 66.0 & 7.4 & 8.6 & 18.4 \\
\hline 12 & 1.3 & 653 & 63.7 & 7.7 & 10.0 & 17.9 \\
\hline 12 & 2.3 & 692 & 58.5 & 12.1 & 9.9 & 15.8 \\
\hline 15 & 1.3 & 648 & 66.6 & 7.2 & 7.1 & 20.0 \\
\hline 15 & 1.4 & 364 & 69.3 & 3.7 & 5.5 & 19.3 \\
\hline 15 & 0.7 & 594 & $--m-$ & --- & --- & ---- \\
\hline $15^{a}$ & 1.3 & 752 & 60.3 & 15.3 & 6.3 & 15.4 \\
\hline
\end{tabular}

a $12-h r$ t.est 


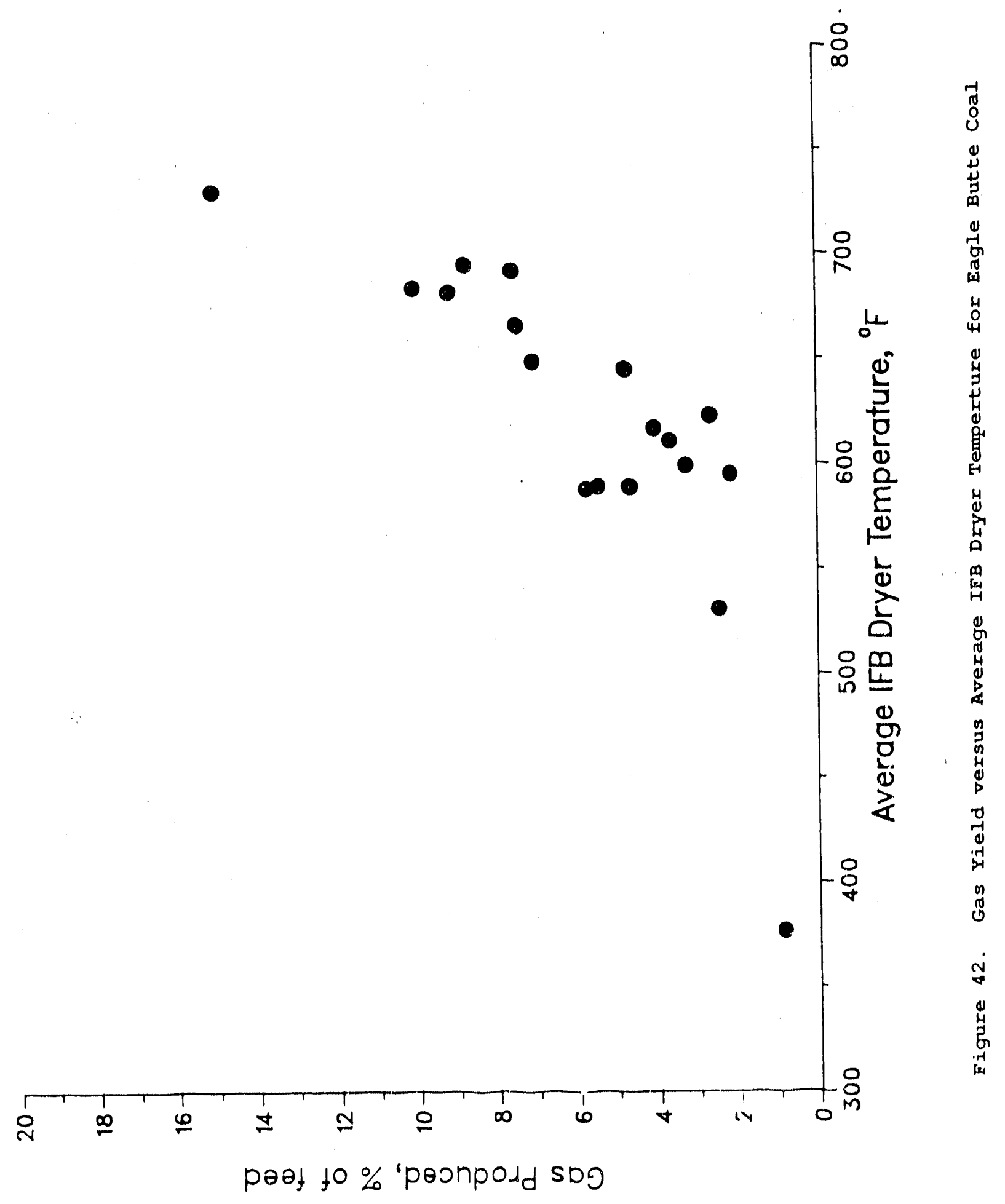




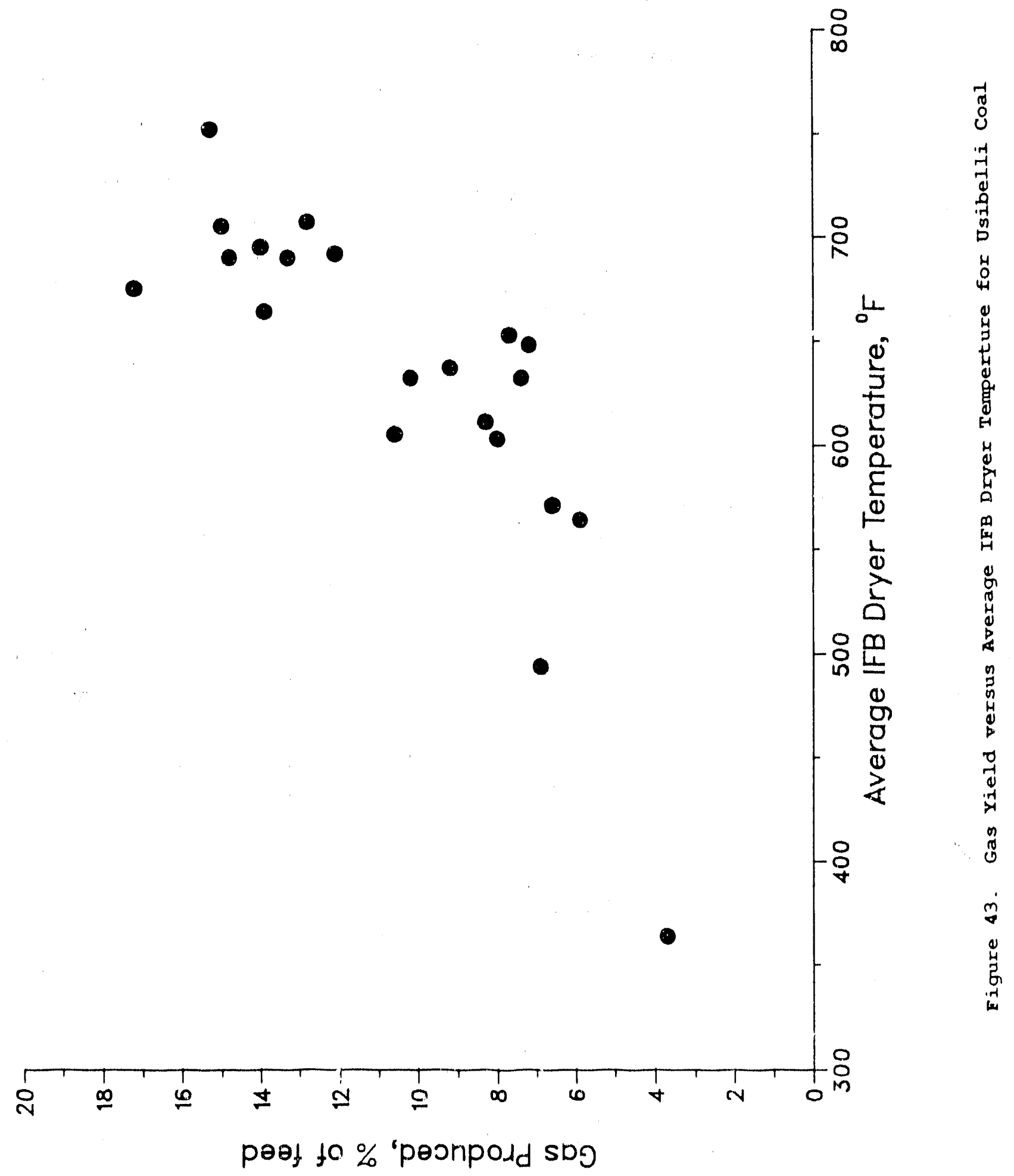




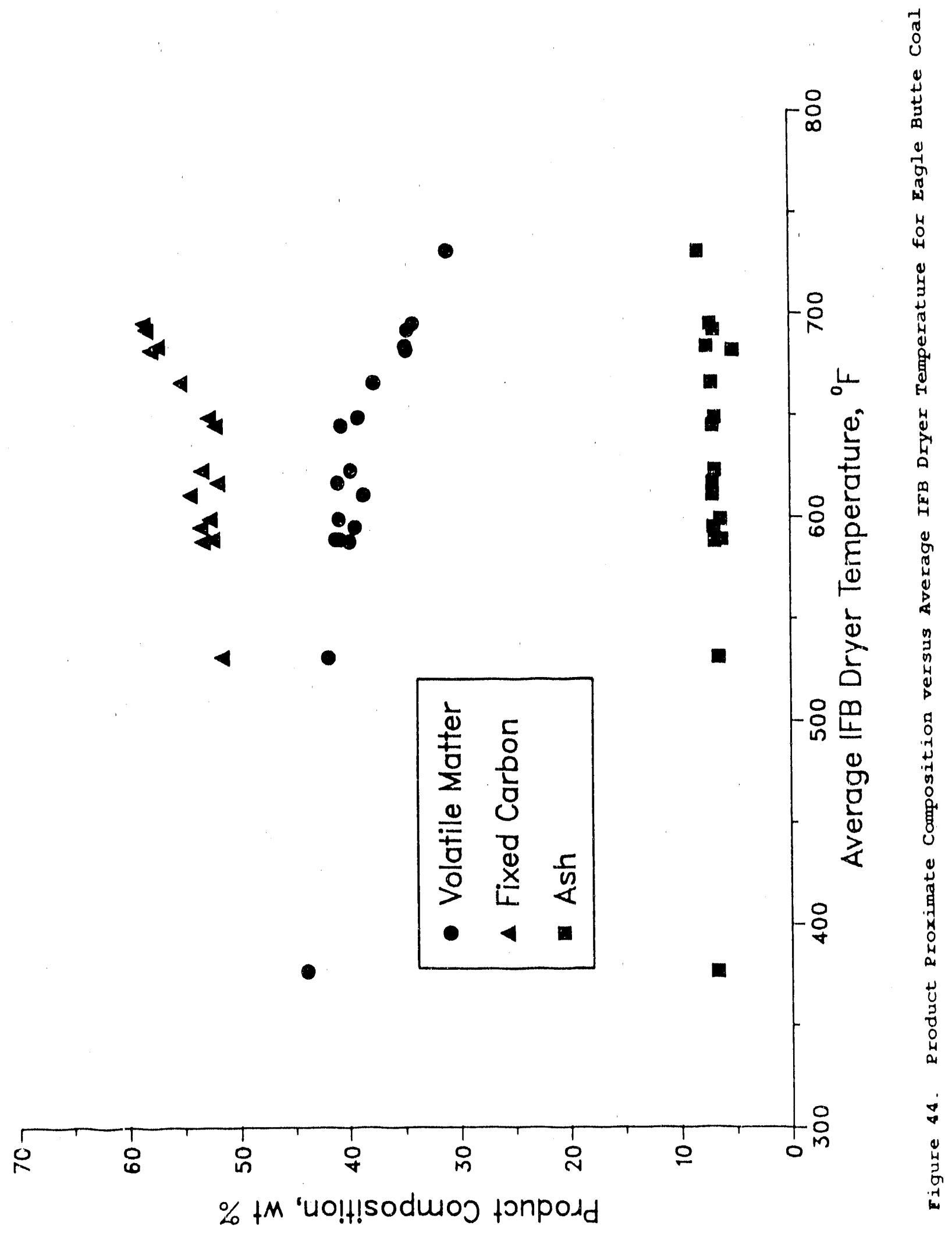




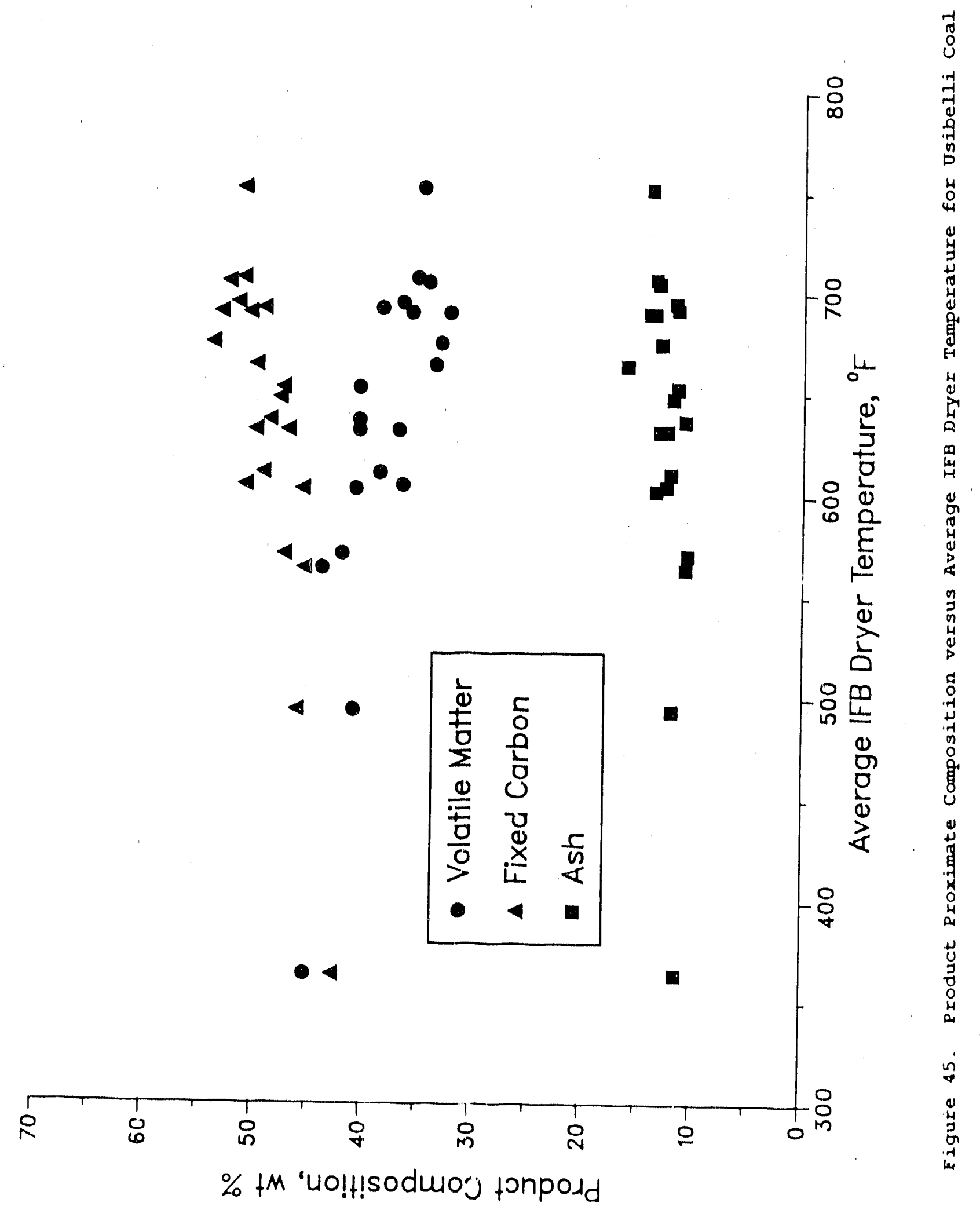


The carbon, hydrogen, nitrogen, sulfur, and oxygen balance closures are summarized in Table 12 for each of the 12-hr tests. In general, the elemental balance clogures for these experiments axe good. However, the hydrogen balance closure was always considerably less than $100 \%$. This is believed to be due to difficulties in accurately determining the elemental composition of the volatile materials removed from the coal during the experiments. In addition, the product compositions as a function of the average IFB drying temperature are presented in Figures 46 and 47 for Eagle Butte coal and in Figures 48 and 49 for Usibelli coal.

Energy balances were also calculated for the 12-hr tests using the results of the proximate balances and gross heating values of the feeds, products, and entrained coal. The heating values of the feed coals presented in Table 2 and the measured heating values of the products and entrained coal were used in all 12-hr experimental energy balances.

The energy distribution for all 12-hr tests is summarized in Table 13. In all of the balances, a 10 to $15 \%$ loss of the heat content of the feed coal was observed. This is probably related to the inability to accurately determine the amount of coll liquids produced. 
Table 12. Sumary of Experimental Elemental Balance Closures for 12-hr Tests

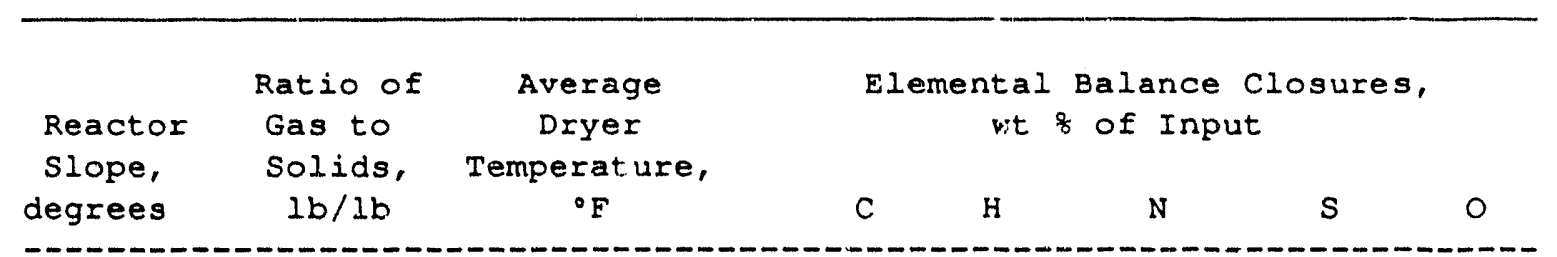

Eagle Butte:

$\begin{array}{rrrrrrrr}3 & 3.9 & 695 & 96.7 & 83.7 & 98.4 & 95.1 & 101.5 \\ 6 & 3.0 & 684 & 96.8 & 77.9 & 103.9 & 100.7 & 101.0 \\ 9 & 1.5 & 611 & 98.1 & 87.5 & 97.3 & 92.0 & 101.1 \\ 15 & 1.4 & 731 & 94.8 & 65.8 & 107.1 & 100.4 & 103.6\end{array}$

Usibelli:

$\begin{array}{rrrrrrrr}3 & 4.0 & 611 & 99.2 & 83.9 & 84.1 & 96.3 & 101.0 \\ 6 & 2.6 & 664 & 97.0 & 70.0 & 102.4 & 98.2 & 101.5 \\ 9 & 1.9 & 632 & 98.4 & 75.9 & 99.4 & 102.4 & 101.8 \\ 15 & 1.3 & 752 & 93.1 & 70.1 & 112.8 & 93.6 & 102.7\end{array}$

a $12-h r$ test 


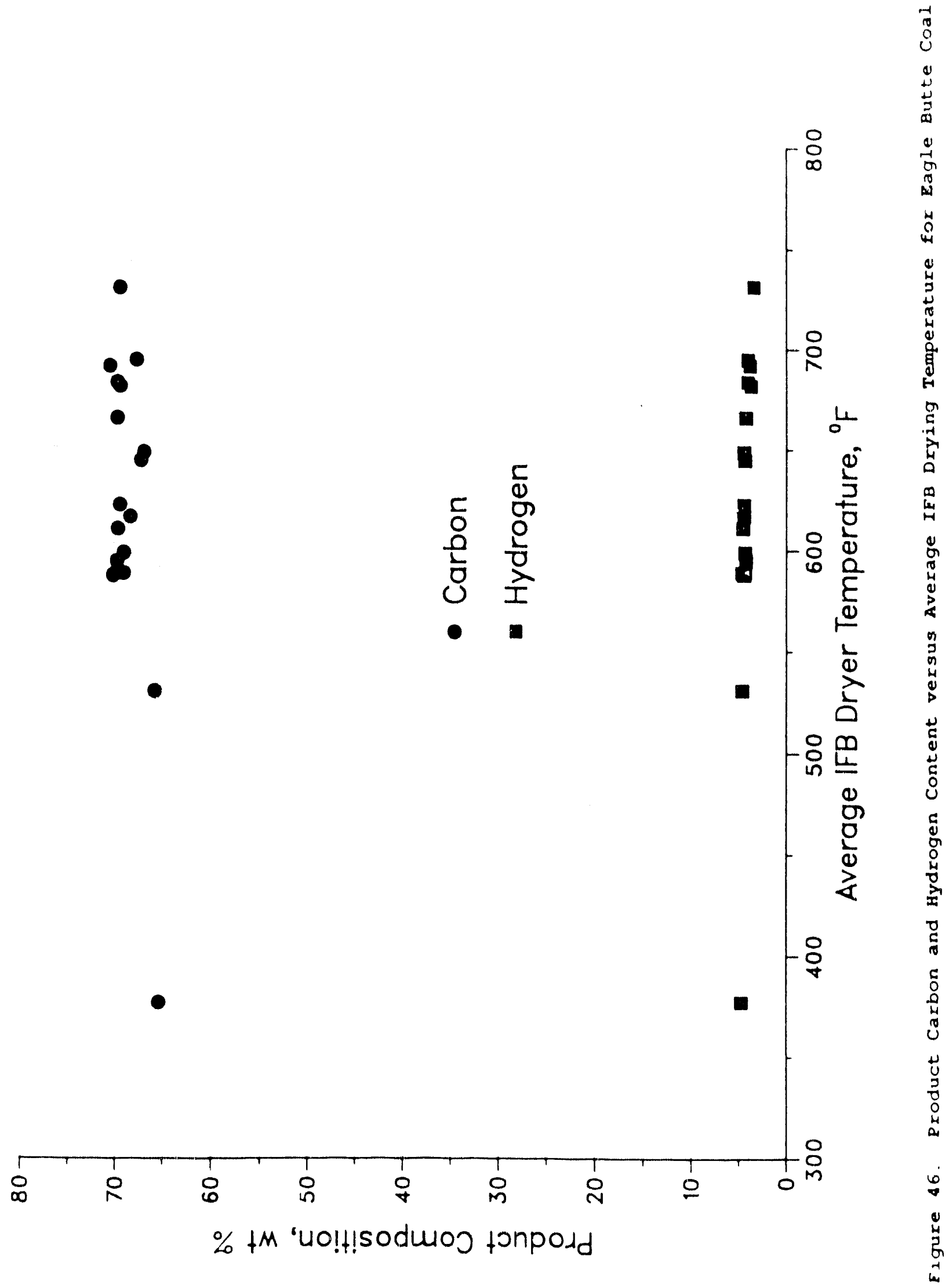




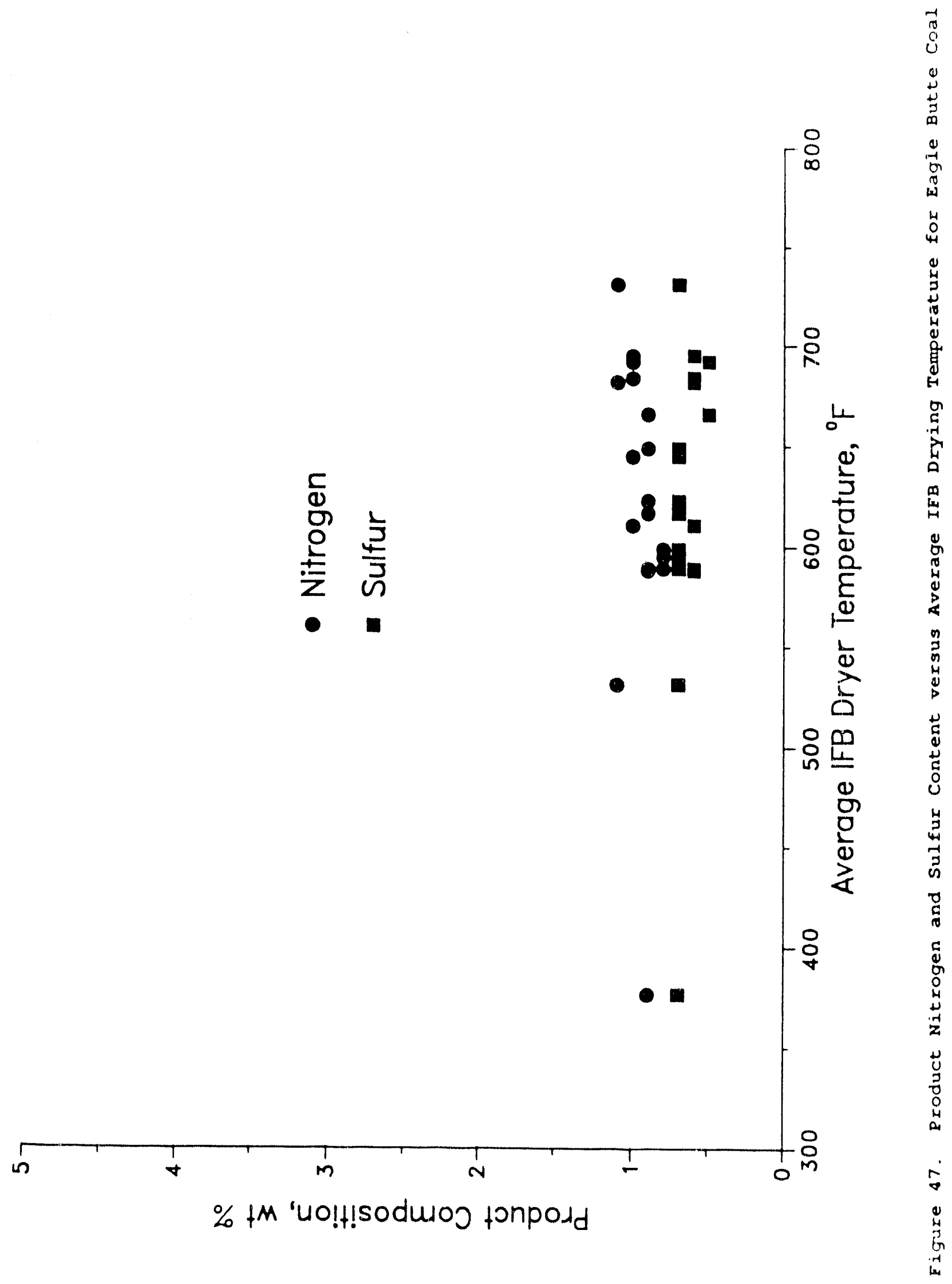




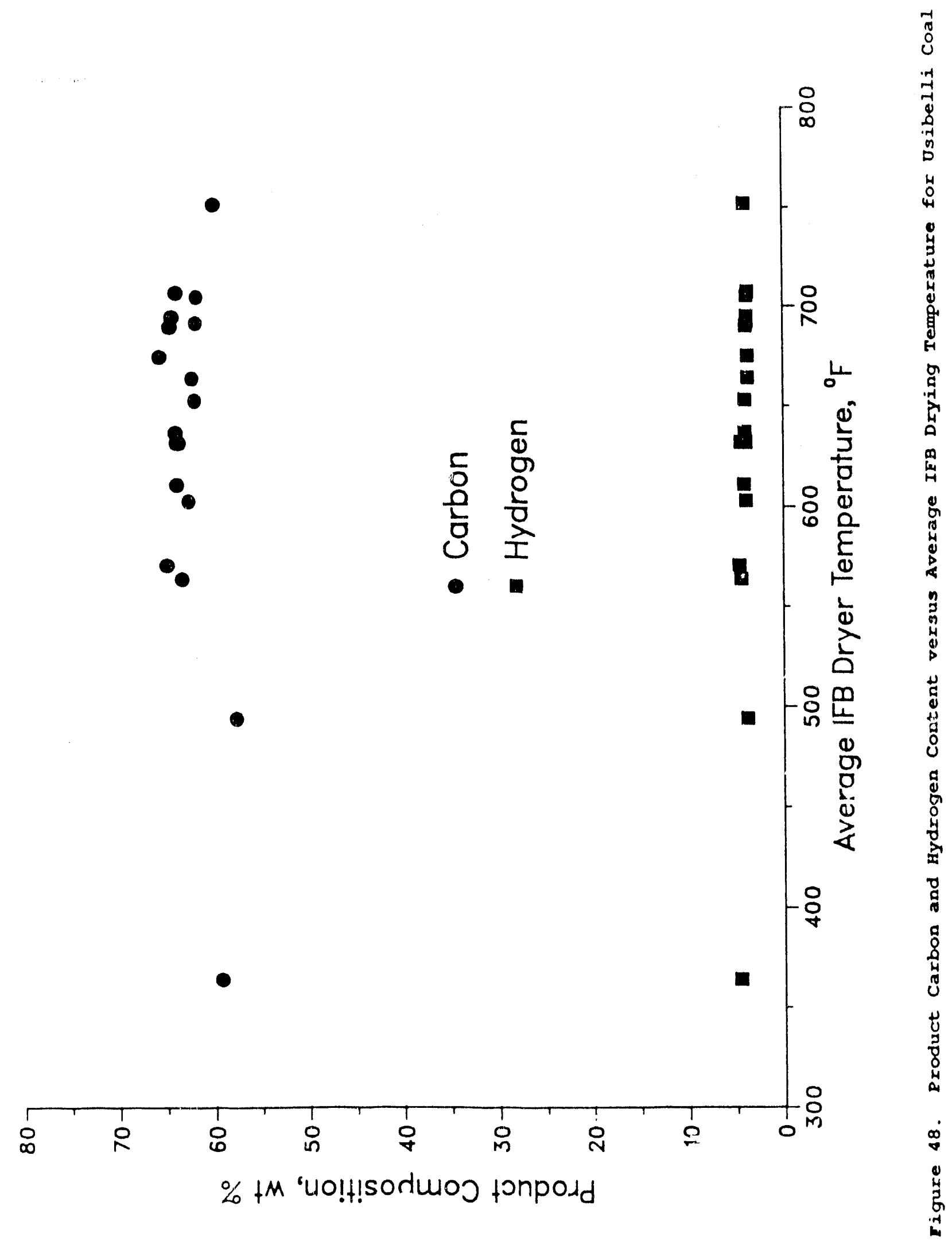




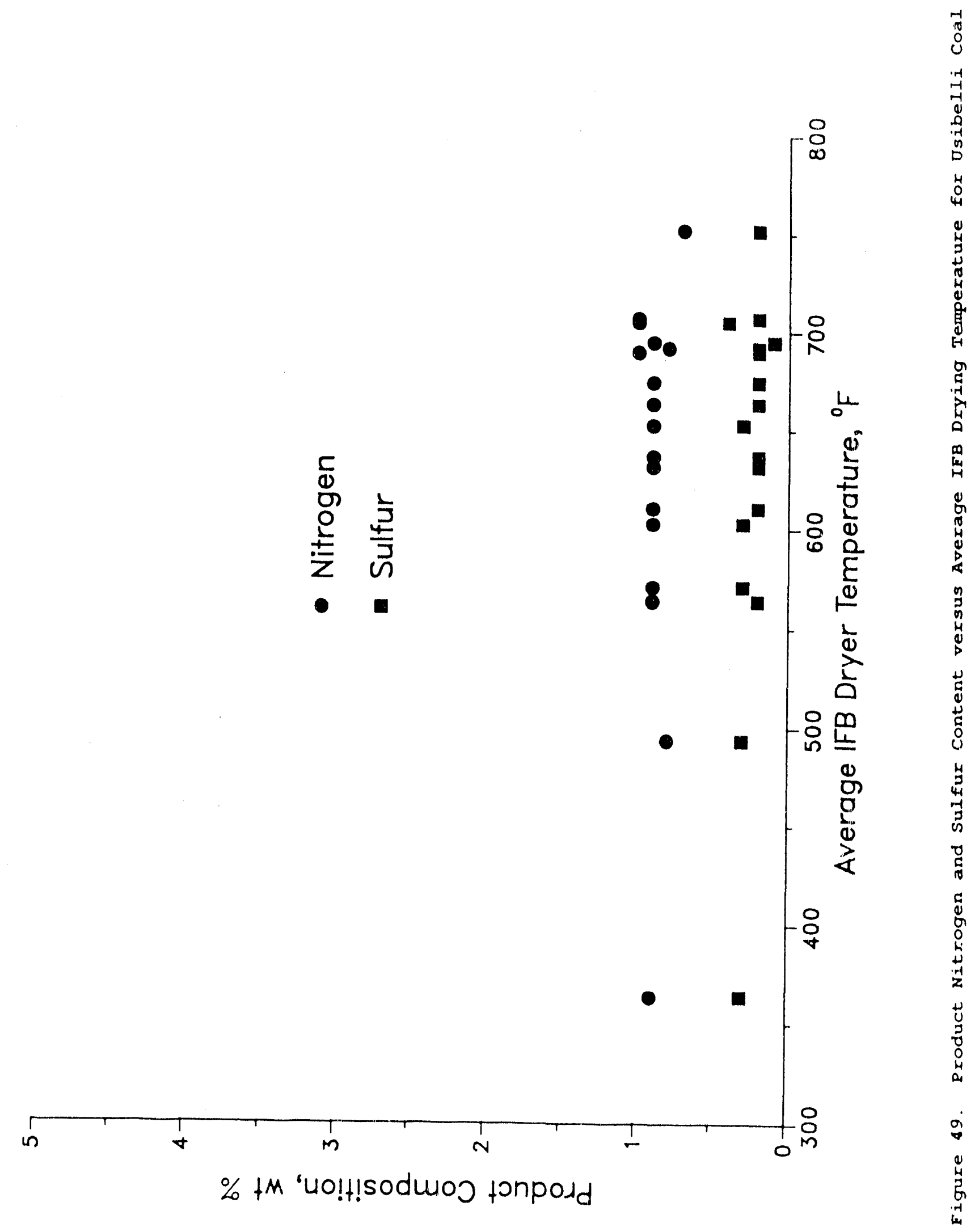




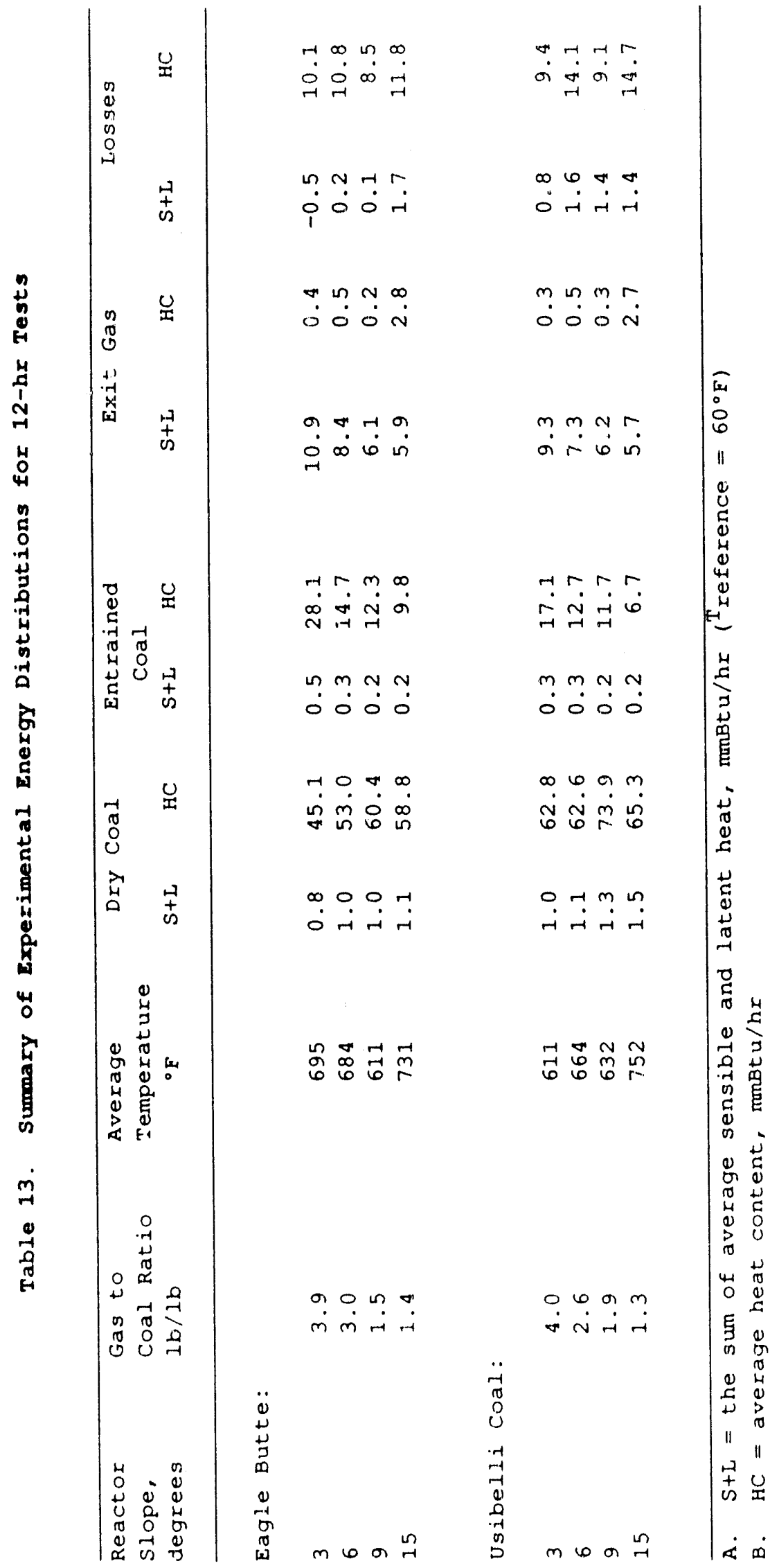


The sensible and latent heat losses indicated by the data in table 13 are believed to be accurate and are primarily related to heat lost by the electric heaters installed at the outside surface of the IfB dryer.

Details of the proximate, elemental, and energy balances for the 12hour tests are provided in Appendix A.

Reynolds numbers (Eq. 2) were calculated for each bench-scale test to non-dimensionalize the fluid flow through the gas-solids disengagement zone and through the solids bed. The Reynolds numbers determined for the disengagement zone are correlated to the amount of entrained solids for each experiment. The Reyrolds numbers determined for the solids bed conditions were used to estimate the average solids residence time, actual solids heating time, and the solids heating rate in the bench-scale experiments.

The exit gas flowrate through the disengagement zone is determined to be the sum of the fluidizing gas flowrate, the dryer nitrogen tracer flowrate $(0.3 \mathrm{scfm}$ in all experiments), and the flowrate of the gas and steam produced from heating the coal. The exit gas velocity is determined using the exit gas flowrate and the surface area of the disengagement zone in the bench-scale IFB dryer (388 in $\left.{ }^{2}\right)$. The ideal gas law is assumed to apply and the gas velocities calaulated are corrected for temperature and pressure using the average IFB temperature and a 0.2 psig reactor pressure. 
Similarly, the fluidizing gas velocity is determined lsing the fluidizing gas flowrate and the surface area immediately above the fluidizing gas distributor in the bench-scale IFB dryer (90 in ${ }^{2}$ ). In determination of the keynolds numbers for both the disengagement zone and the coal bed at the bottom of the IFB dryer, the average coal particle diameters used are based upon wet screen analyses results of the feed coals. The coal particle densities used were experimentally determined.

Herning and zipperer (Katz, et al. 1959) proposed the following rule to calculate the viscosity of a mixture of gases:

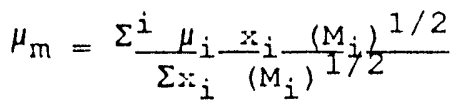

$$
\text { where } \quad \begin{aligned}
& \mu_{m}=\text { the viscosity of the gas mixture } \\
& \mu_{i}=\text { the viscosity of component } i \\
& x_{i}=\text { the mole fraction of component } i \\
& M_{i}=\text { the molecular weight of component } i
\end{aligned}
$$

The viscosity of the carbon dioxide (fluidizing gas) is calculated using the following equation (Bird et al., 1960):

$$
\mu_{g}=\left(2.6693 \times 10^{-5}\right) \frac{(M T)^{1 / 2}}{\sigma^{2} \Omega}
$$

where

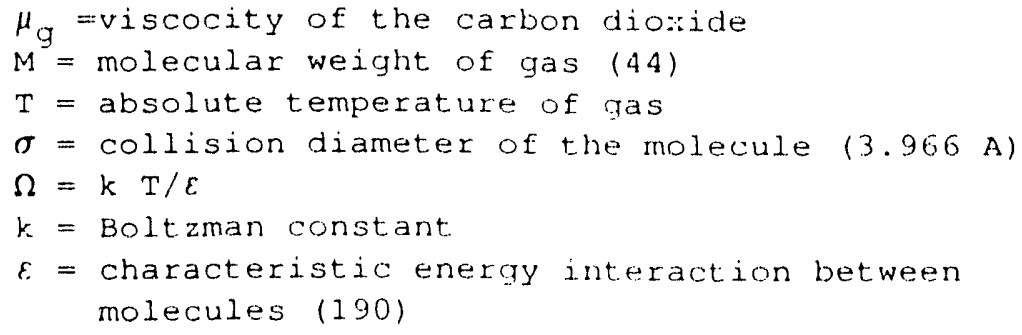


The viscosity of other gas species and steam in the exit stream were found in the literature (Mccabe and smith, 1967) for each average IFr dryer temperature in the eight 12-hour bench-scale tests. The viscosity calculated from Equation 3 for the mixture of non-condensable gases in the exit gas was found to be the same (within 3 decimal places) as the viscosity of pure carbon dioxide calculated from Equation 4 . This is probably due to the fact that the carhon dioxide concentration of the noncondensable portion of the exit gas from the bench-scale IfB drying tests was always greater than $85 \%$. For this reason the viscosity of the noncondensable exit gas fraction in the 4 -hr tests was assumed to be equal to the viscosity of pure carbon dioxide at the average IFB dryer temperatures considered. The viscosity of the total exit gas stream was calculated from Equation 3 using the carbon dioxide viscosity and steam viscosity at the average IFB dryer temperature and the mole fractions of noncondensablee gases and steam in the exit gas.

The IFB dryer slope, flowrate and viscosity of exit gas, average IFB dryer temperature, and the Reynolds number at the disensagement zone o: the reactor resulting for each test are provided in Tables 14 and 15 for Eagle Butte and Usibelli coals, respectively. The Reynolds numbers based upon flow conditions in the disengagement zone of the IFB dryer are the min:mum Reynolds numbers in the reactor.

The amount of entrained coal from the IFB dryer is of economic significance to plans for use of coal fines. The relationship of the coal entrainment to the Reynolds nunber in the disengagement zone of the IFB is illustrated in Figures 50 and 51 for the bench-scale IfB drying tests 
using Eagle Butte and Usibelii coals, respectively. If the Reynolds number is maintained below 90, entrained coal from the dryer is less than 158 of the Eagle Butte coal and is less than $10 \%$ of the Usibelli coal.

The IFB dryer slope, fluidizing gas flowrate, fluidizing gas velocity, average IFB dryer temperature, and the Reynolds number at the bottom of the reactor are provided in Tables 16 and 17 for each test of Eagle Butte and Usibelli coals, respectively. The Reynolds numbers based upon flow conditions at the bottom of the IFB dryer are the maximum Reynolds numbers in the reactor. 
Table 14. Minimum Reynolds Numbers for IFB Bench-Scale Drying Tests using Eagle Butte Coal

\begin{tabular}{|c|c|c|c|c|}
\hline $\begin{array}{l}\text { Reactor } \\
\text { slope, } \\
\text { degrees }\end{array}$ & $\begin{array}{l}\text { Exit } \\
\text { Gas } \\
\text { Elowrate, } \\
\text { scfim }\end{array}$ & $\begin{array}{c}\text { Exit } \\
\text { Gas } \\
\text { Velocity, } \\
\text { ft/min }\end{array}$ & $\begin{array}{c}\text { Average } \\
\text { Dryer } \\
\text { 'iemperature, } \\
{ }^{\circ} \mathrm{F}\end{array}$ & $\begin{array}{l}\text { Minimum } \\
\text { Reynolds } \\
\text { Number } \\
\text { in IFB }\end{array}$ \\
\hline 3 & 7.8 & 7.7 & 589 & 128 \\
\hline 3 & 6.1 & 5.7 & 531 & 103 \\
\hline $3^{a}$ & 7.1 & 7.6 & 695 & 119 \\
\hline 6 & 7.7 & 7.6 & 595 & 130 \\
\hline 6 & 6.2 & 6.2 & 599 & 1.02 \\
\hline 6 & 6.0 & 6.1 & 623 & 100 \\
\hline 6 & 4.3 & 4.6 & 666 & 74 \\
\hline $6^{a}$ & 5.4 & 5.8 & 684 & 92 \\
\hline 9 & 5.8 & 5.8 & 617 & 95 \\
\hline 9 & 4.8 & 4.7 & 589 & 80 \\
\hline 9 & 4.1 & 4.0 & 588 & 70 \\
\hline 9 & 7.4 & 7.9 & 692 & 123 \\
\hline $9^{a}$ & 3.8 & 3.8 & 611 & 67 \\
\hline 12 & --- & --- & 603 & $-\cdots$ \\
\hline 12 & 3.5 & 3.7 & 649 & 61 \\
\hline 12 & 5.1 & 5.5 & 682 & 88 \\
\hline 15 & 3.5 & 3.6 & 645 & 61 \\
\hline 15 & 3.3 & 2.6 & 377 & 55 \\
\hline 15 & --- & --- & 589 & --- \\
\hline $15^{\mathrm{a}}$ & 3.3 & 3.7 & 731 & 58 \\
\hline
\end{tabular}

a $12-h r$ test 
Table 15. Minimum Reynolds Numbers for IFB Bench-Scale Drying Tests using Usibelli Coal

\begin{tabular}{|c|c|c|c|c|}
\hline $\begin{array}{l}\text { Reactor } \\
\text { Slope, } \\
\text { degrees }\end{array}$ & $\begin{array}{l}\text { Exit } \\
\text { Gas } \\
\text { Flowrate, } \\
\text { scfm }\end{array}$ & $\begin{array}{c}\text { Exit } \\
\text { Gas } \\
\text { velocity, } \\
\text { ft } / \mathrm{min}\end{array}$ & $\begin{array}{c}\text { Average } \\
\text { Dryer } \\
\text { Temperature, } \\
{ }^{\circ} \mathrm{E}\end{array}$ & $\begin{array}{l}\text { Minimum } \\
\text { Reynolds } \\
\text { Number } \\
\text { in IFB }\end{array}$ \\
\hline 3 & 4.7 & 4.2 & 494 & 84 \\
\hline 3 & 6.8 & 7.4 & 705 & 126 \\
\hline 3 & 7.4 & 7.9 & 690 & 136 \\
\hline 3 & 6.2 & 6.2 & 605 & 113 \\
\hline $3^{a}$ & 7.4 & 7.4 & 611 & 134 \\
\hline 6 & 5.2 & 5.6 & 690 & 97 \\
\hline 6 & 4.4 & 4.7 & 675 & 82 \\
\hline 6 & 6.4 & 6.9 & 695 & 1.18 \\
\hline 6 & 5.1 & 4.9 & 564 & 94 \\
\hline $6^{a}$ & 5.2 & 5.5 & 664 & 96 \\
\hline 9 & 6.1 & 6.3 & 637 & 114 \\
\hline 9 & 5.8 & 5.6 & 571 & 10 \\
\hline 9 & 4.4 & 4.4 & 603 & 82 \\
\hline 9 & 7.3 & 8.0 & 707 & 136 \\
\hline $9^{a}$ & 4.3 & 4.4 & 632 & 79 \\
\hline 12 & 3.6 & 3.7 & 632 & 69 \\
\hline 12 & 3.1 & 3.3 & 653 & 60 \\
\hline 12 & 4.7 & 5.0 & 692 & 87 \\
\hline 15 & 3.3 & 3.4 & 648 & 63 \\
\hline 15 & 3.2 & 2.5 & 364 & 59 \\
\hline 15 & $--\infty$ & --- & 594 & --- \\
\hline $15^{\mathrm{a}}$ & 3.3 & 3.8 & 752 & 64 \\
\hline
\end{tabular}

a $12-$ hr test 


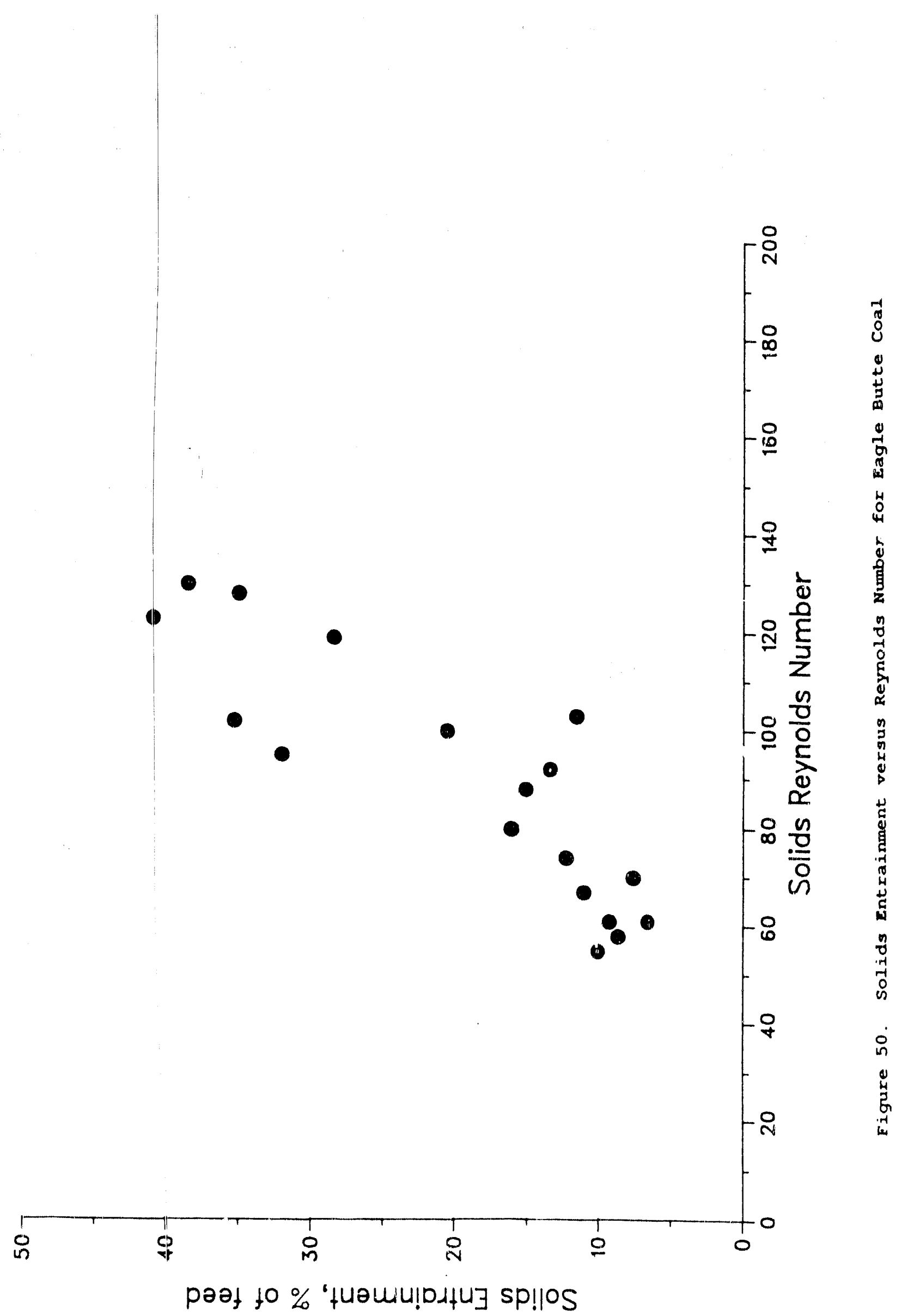




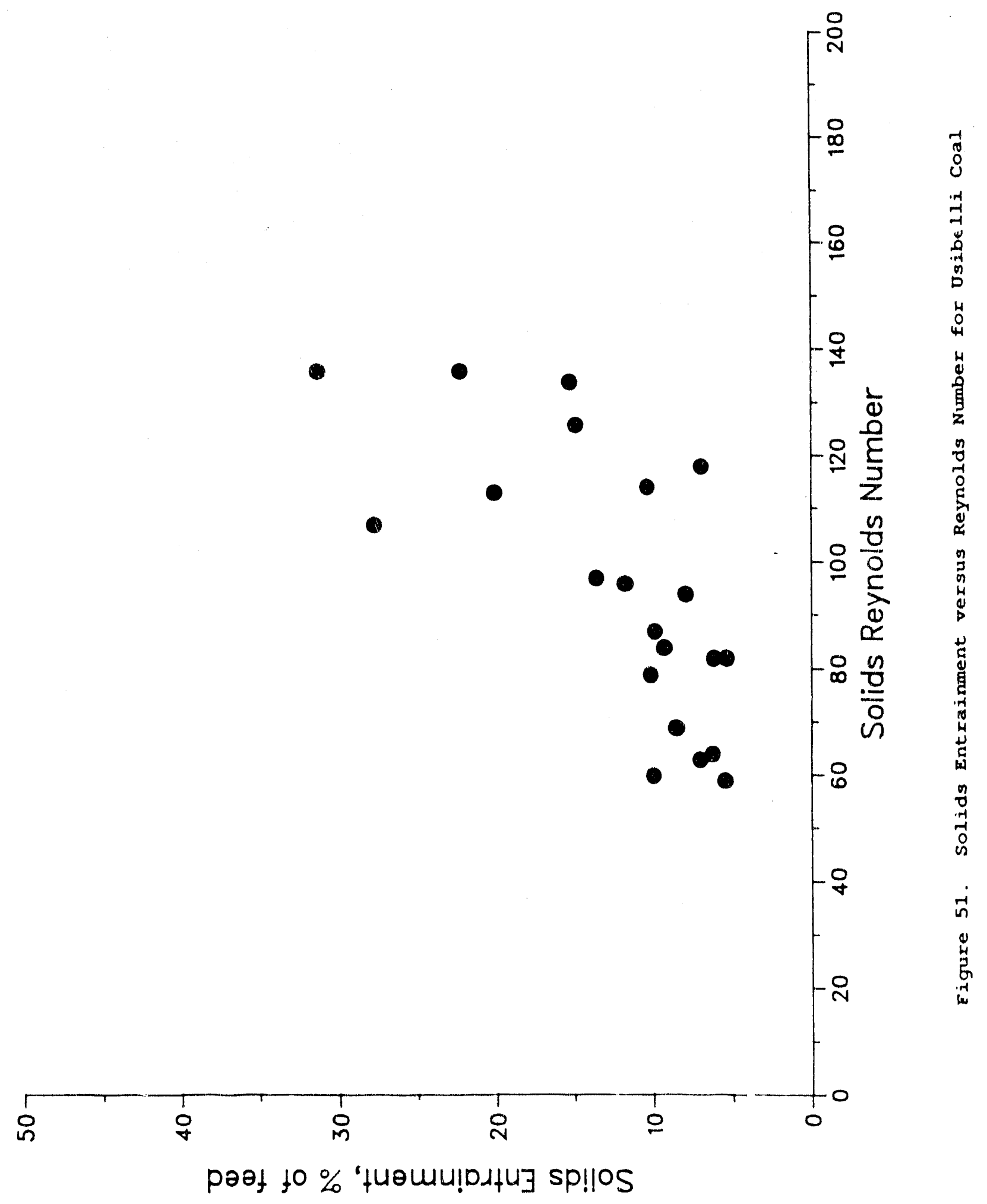


Table 16. Maximum Reynolds Numbers for IFB Bench-Scale Drying Tests using Eagle Butte Coal

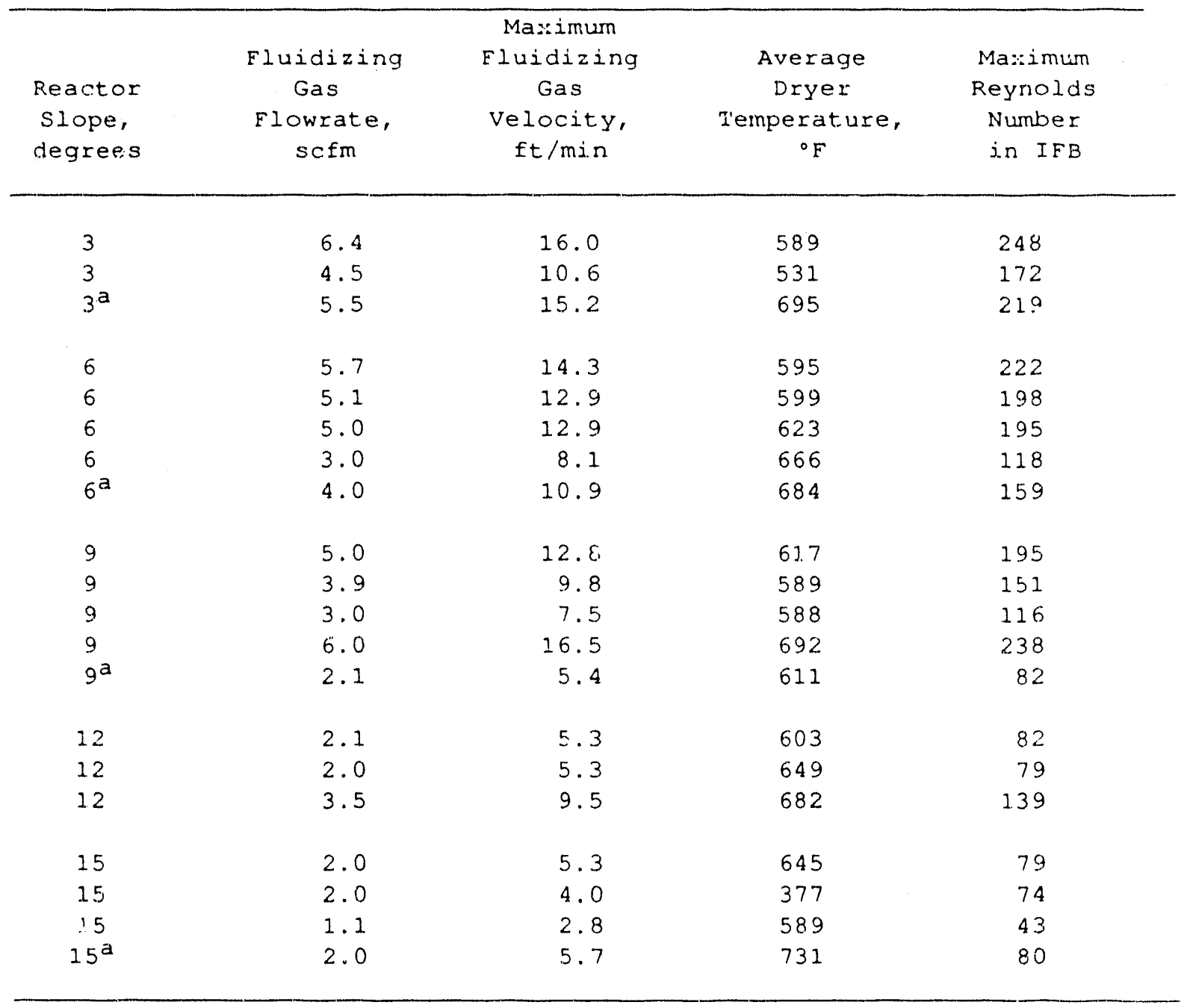

a $12-\mathrm{hr}$ test 
Table 17. Maximum Reynolds Number for IFB Bench-Scale Drying Tests using Usibelli Coal

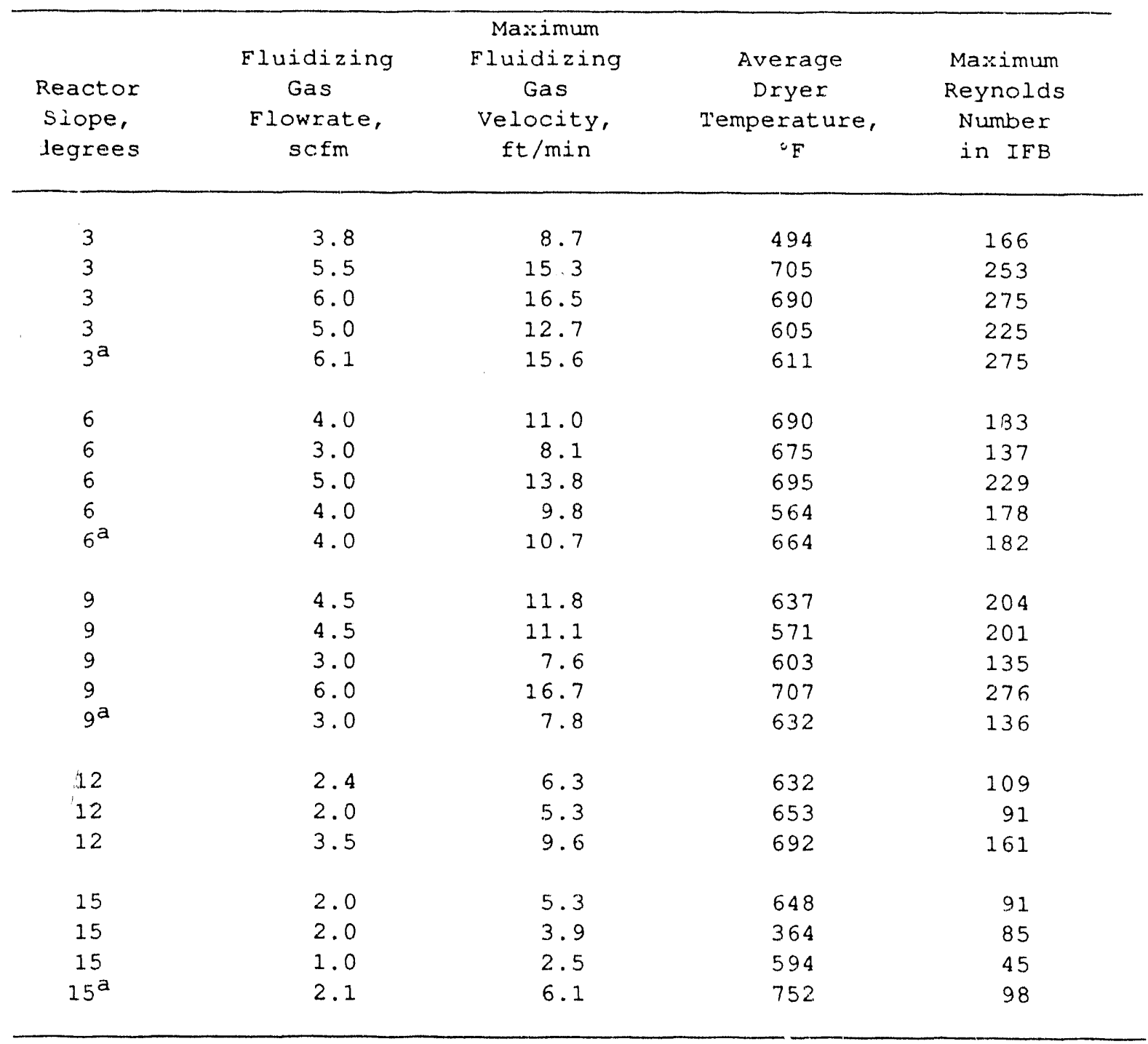

a 12-hr test 


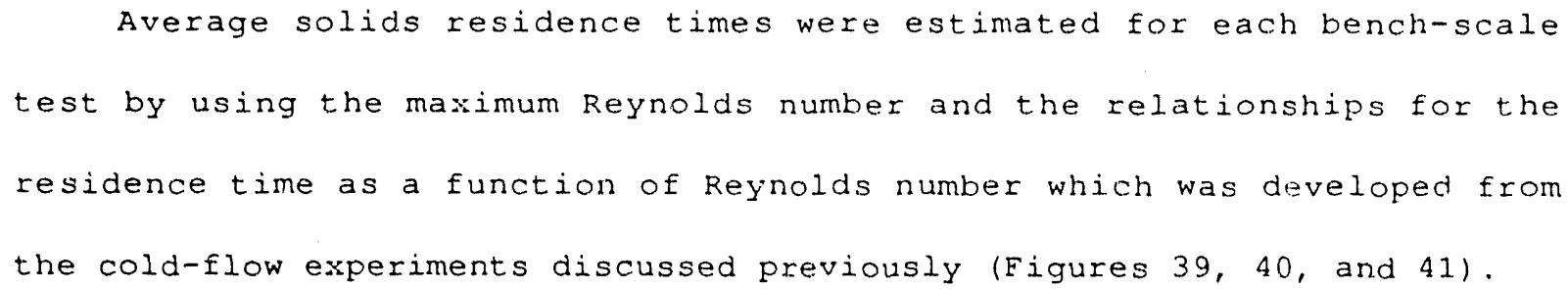

The heating rate of the coal particles in the IFB bench-scale tests was determined from the maximum zone temperature in the IfB dryer, and the amount of time the coal particles were heated. The maximum average zone temperature in the IFB dryer was determined from the experimental data. The location of this zone and the average coal residence time for the experiment were then used to determine the amount of time the coal particles were heated. In all experiments the maximum zone temperature occurred between 30 and 45 inches from the feed end of the reactor. In all cases the coal particles were cooled in the last quarter of the reactor. Coal hearing rates for each experiment were estimated using the maximum zone temperature and the amount of time the coal particles were heated.

The average coal residence times, coal heating times, and the heating rates are summarized in Tables 18 and 19 for Eagle Butte and Usibelii coals, respectively. The average coal residence times ranged from approximately 5 to 13 minutes for all the experiments; the actual heating time of the coal particles ranged from approximately 3 to 9 minutes for all the experiments; and, the heating rates ranged from approximately s0 to $200^{\circ} \mathrm{F} / \mathrm{min}$ in experiments using Eagle Butte coal and from approximately 70 to $250^{\circ} \mathrm{F} / \mathrm{min}$ in experiments using Usibelli coal. 
Tab.- 18. Coal Residence Times and Heating Ratas for IFB Bench-Scale Drying Tests using Eagle Butte Coal

\begin{tabular}{|c|c|c|c|c|c|}
\hline $\begin{array}{l}\text { Reactor } \\
\text { slope, } \\
\text { degrees }\end{array}$ & $\begin{array}{c}\text { Average } \\
\text { Dryer } \\
\text { Temperature, } \\
{ }^{\circ} \mathrm{F}\end{array}$ & $\begin{array}{l}\text { Maximum } \\
\text { Reynolds } \\
\text { Number } \\
\text { in IFB }\end{array}$ & $\begin{array}{l}\text { Average } \\
\text { Coal } \\
\text { Residence } \\
\text { Time, } \\
\text { min }\end{array}$ & $\begin{array}{l}\text { Coal } \\
\text { Heating } \\
\text { Time } \\
\text { Required, } \\
\text { min }\end{array}$ & $\begin{array}{l}\text { Coal } \\
\text { Heating } \\
\text { Rate, } \\
{ }^{\circ} \mathrm{F} / \mathrm{min}\end{array}$ \\
\hline 3 & 589 & 248 & 11 & 6 & 100 \\
\hline 3 & 531 & 172 & 12 & 9 & 60 \\
\hline $3^{a}$ & 695 & 219 & 11 & 9 & 80 \\
\hline 6 & 595 & 222 & 10 & 5 & 120 \\
\hline 6 & 599 & 198 & 10 & 5 & 120 \\
\hline 6 & 623 & 195 & 10 & 5 & 120 \\
\hline 6 & 666 & 118 & 12 & 9 & 70 \\
\hline $6^{a}$ & 684 & 159 & 11 & 6 & 120 \\
\hline 9 & 617 & 195 & 6 & 3 & 180 \\
\hline 0 & 589 & 151 & 7 & 3 & 170 \\
\hline 9 & 588 & 116 & 7 & 4 & 160 \\
\hline 9 & 692 & 238 & 6 & 4 & 160 \\
\hline $9^{a}$ & 611 & 82 & 8 & 6 & 100 \\
\hline 12 & 603 & 82 & 7 & 5 & 120 \\
\hline 12 & 649 & 79 & 7 & 5 & 130 \\
\hline 12 & 682 & 139 & 6 & 4 & 160 \\
\hline 15 & 645 & 79 & 5 & 4 & 180 \\
\hline 15 & 377 & 74 & 5 & 4 & 90 \\
\hline 15 & 589 & 43 & 5 & 4 & 1.50 \\
\hline $15^{a}$ & 731 & 80 & 5 & 4 & 200 \\
\hline
\end{tabular}

a $12-h r$ test 
Table 19. Coal Residence Times and Heating Rates for IFB Bench-Scale Drying Tests using Usibelii Coal

\begin{tabular}{|c|c|c|c|c|c|}
\hline $\begin{array}{l}\text { Reactor } \\
\text { Slope. } \\
\text { degrees }\end{array}$ & $\begin{array}{c}\text { Average } \\
\text { Dryer } \\
\text { Temperature, } \\
{ }^{\circ} \mathrm{F}\end{array}$ & $\begin{array}{l}\text { Maximum } \\
\text { Reynolds } \\
\text { Number } \\
\text { in IFB }\end{array}$ & $\begin{array}{l}\text { Average } \\
\text { Coal } \\
\text { Residence } \\
\text { Time, } \\
\text { min }\end{array}$ & $\begin{array}{l}\text { Coal } \\
\text { Heating } \\
\text { Time } \\
\text { Reguired, } \\
\text { min }\end{array}$ & $\begin{array}{c}\text { Coal } \\
\text { Heating } \\
\text { Rate, } \\
\text { of/min }\end{array}$ \\
\hline 3 & 494 & 166 & 13 & 6 & 80 \\
\hline 3 & 705 & 253 & 11 & 8 & 80 \\
\hline 3 & 690 & 275 & 10 & 5 & 130 \\
\hline 3 & 605 & 225 & 11 & 8 & 70 \\
\hline $3^{a}$ & 611 & 275 & 10 & 8 & 80 \\
\hline 6 & 690 & 1.83 & 10 & 5 & 130 \\
\hline 6 & 675 & 137 & 12 & 6 & 110 \\
\hline 6 & 695 & 229 & 9 & 5 & 140 \\
\hline 6 & 564 & 178 & 10 & 8 & 70 \\
\hline $6^{a}$ & 664 & 182 & 10 & 5 & 130 \\
\hline 9 & 637 & 204 & 6 & 5 & 130 \\
\hline 9 & 571 & 201 & 6 & 3 & 180 \\
\hline 9 & 603 & 135 & 7 & 5 & 110 \\
\hline 9 & 707 & 276 & 5 & 3 & 250 \\
\hline $9^{a}$ & 632 & 136 & 7 & 5 & 120 \\
\hline 12 & 632 & 109 & 6 & 5 & 140 \\
\hline 12 & 653 & 91 & 7 & 5 & 130 \\
\hline 12 & 692 & 161 & 6 & 4 & 170 \\
\hline 15 & 648 & 91 & 5 & 4 & 170 \\
\hline 15 & 364 & 85 & 5 & 4 & 90 \\
\hline 15 & 594 & 45 & 5 & 4 & 150 \\
\hline $15^{a}$ & 752 & $98^{\prime}$ & 5 & 4 & 220 \\
\hline
\end{tabular}

a $12-h r$ test 
Task 4--Product Characterization and Testing

Feed coals and selected test products were characterized for moisture reabsorption, dustiness, and spontaneous heating tendencies. Surface area and particle size were determined on selected feed and dried coal samples.

Subtask. 4.1--Moisture Reabsorption

Moisture reabsorption was determined from tests conducted using a controlled temperature/humidity chamber. Conditions similar to those used for equilibrium moisture measurements $\left(30^{\circ} \mathrm{C}\right.$ and about 958 relative humidity) were utilized for most tests. Additional tests were conducted using lower levels of relative humidity (RH) which are more typical of the conditions encounterer during storage and transportation of the dried coal.

Eagle Butte and Usibelli feed coals and selected test products were subjected to moisture reabsorption tests as shown by the results in Tables 20 and 21. A significant reduction in equilibrium moisture occurred following inclined fluidized-bed drying. The moisture reabsorption is a function of the drying temperature as evidenced by greater equilibrium moisture values for samples dried at the lower emperatures. For example, Eagle Butte and Usibelii coals which were dried at relatively low temperatures (samples $D-49$ and $D-48$ ) exhibited the greatest values of moisture reabsorption and equilibrium moisture. Figure 52 shows moisture reabsorption as a function of the average drying temperature for both the Eagle Butte and Usibelli coals. 
Table 20. Reabsorption of Moisture by Eagle Butte Coal

\begin{tabular}{|c|c|c|c|c|}
\hline \multirow[b]{2}{*}{ Sample } & \multirow{2}{*}{$\begin{array}{l}\text { Average } \\
\text { Dryer } \\
\text { Temp, }{ }^{\circ} \mathrm{F}\end{array}$} & \multicolumn{3}{|c|}{ Moisture Content, wt 8} \\
\hline & & $\begin{array}{l}\text { As } \\
\text { Received }\end{array}$ & $\begin{array}{l}\text { Moisture } \\
\text { Reabsorption }\end{array}$ & $\begin{array}{l}\text { Equilibrium } \\
\text { Moisture }\end{array}$ \\
\hline EB Feed & --- & 28.1 & 27.3 & 26.9 \\
\hline D-39 Feed & --- & 19.7 & 21.7 & 26.1 \\
\hline$D-45$ Feed & --- & 26.8 & 26.5 & 28.2 \\
\hline$D-53$ Feed & $\cdots-$ & 16.2 & 19.4 & 23.5 \\
\hline$D-2$ & 586 & 2.6 & 13.8 & 12.8 \\
\hline$D-30$ & 531 & 1.9 & 16.8 & 16.0 \\
\hline$D-31$ & 695 & 0.6 & 13.9 & 13.2 \\
\hline$D-37$ & 684. & 0.9 & 14.4 & 12.5 \\
\hline$D-39$ & 611 & 0.8 & 14.6 & 13.4 \\
\hline$D-41$ & 603 & 0.7 & 14.9 & 15.9 \\
\hline$D-45$ & 682 & 1.0 & 13.9 & 13.4 \\
\hline$D-47$ & 645 & 0.7 & 14.2 & 14.2 \\
\hline$D-49$ & 375 & 0.4 & 18.6 & 19.9 \\
\hline$D-51$ & 589 & 1.0 & 15.6 & 14.1 \\
\hline$D-53$ & 731 & 0.6 & 14.0 & 12.2 \\
\hline
\end{tabular}

1 reabsorption of moisture upon exposure of the as-is sample to conditions of $95 \%$ relative humidity $/ 30^{\circ} \mathrm{C}$ for 5 days.

2 reabsorption of moisture in samples which were first immersed in deionized water and then exposed to conditions of $95 \%$ relative humidity $/ 30^{\circ} \mathrm{C}$ for 5 days.

Table 21. Reabsnrption of Moisture by Usibelli Coal

\begin{tabular}{|c|c|c|c|c|}
\hline \multirow[b]{2}{*}{ Sample } & \multirow{2}{*}{$\begin{array}{l}\text { Average } \\
\text { Dryer } \\
\text { Temp, }{ }^{\circ} \mathrm{F}\end{array}$} & \multicolumn{3}{|c|}{ Moisture Content, wt o } \\
\hline & & $\begin{array}{l}\text { As } \\
\text { Received }\end{array}$ & $\begin{array}{l}\text { Moisture } \\
\text { Reabsorption }\end{array}$ & $\begin{array}{l}\text { Equilibrium } \\
\text { Moisture }\end{array}$ \\
\hline USI Feed & -- & 20.3 & 21.1 & 21.4 \\
\hline$D-38$ Feed & --- & 14.3 & 17.7 & 20.4 \\
\hline$D-44$ Feed & --- & 15.9 & 19.1 & 21.4 \\
\hline$D-52$ Feed & $-\infty$ & 12.8 & 16.1 & 20.4 \\
\hline$D-29$ & 494 & 1.1 & 14.7 & 15.9 \\
\hline$D-32$ & 705 & 0.3 & 14.6 & 13.5 \\
\hline$D-35$ & 611 & 0.7 & 15.3 & 14.4 \\
\hline$D-36$ & 664 & 0.8 & 13.7 & 1.3 .8 \\
\hline$D-38$ & 631 & 0.9 & 15.0 & 1.4 .3 \\
\hline$D-43$ & 653 & 0.4 & 14.8 & 14.5 \\
\hline$D-46$ & 648 & 0.5 & 14.5 & 14.1 \\
\hline$D-48$ & 364 & 0.3 & 18.8 & 19.6 \\
\hline$D-50$ & 594 & 0.6 & 15.9 & 14.4 \\
\hline$D-52$ & 752 & 0.6 & 15.0 & 13.3 \\
\hline
\end{tabular}


The dried coals reabsorbed roughly the same amount of moisture regardless of whether they were first immersed in deionized water to saturate the coal pores or not. As shown in Figure 52 , the level of moisture reabsorption into the dried coal does not appear to be a function of coal type. Fven though the Usibeli feed coal contained a lower level of equilibrium moisture than the Eagle Butte feed coal; the dried Usibelli and Eagle Butte aoals exhibited similar moisture reabsorption characteristios when dried under similar conditions.

Additional moisture reabsorption tests were conducted using conditions of lower relative humidity which are more representative of environments encountered during storage and transportation. Average values near 50 percent relative humidity are typical for areas such as Colorado and utah. Average values near 80 percent relative humidity are typical for areas along the western coast of the, United States i.e. San Francisco and Seattle. Many other areas of the United States experience average relative humidities between these values. Average temperatures, however, are typically lower than the $30^{\circ} \mathrm{C}$ used for the moisture reabsorption tests. For these additional tests, conditions of $30^{\circ} \mathrm{C}$ and 50 and 80 percent relative humidities were utilized. The temperature was fixed at $30^{\circ} \mathrm{C}$ in order to allow comparison of the effect of relative humidity only.

As shown in Table 22, significantly lower levels of moisture reabsorption were obtained using the lower-humidity conditions. For example, the dried Eagle Butte coal samples subjected to the 50 selative humidity environment exhibited moisture reabsorption and equilibrium moisture values between about 7 and 9 percent. 


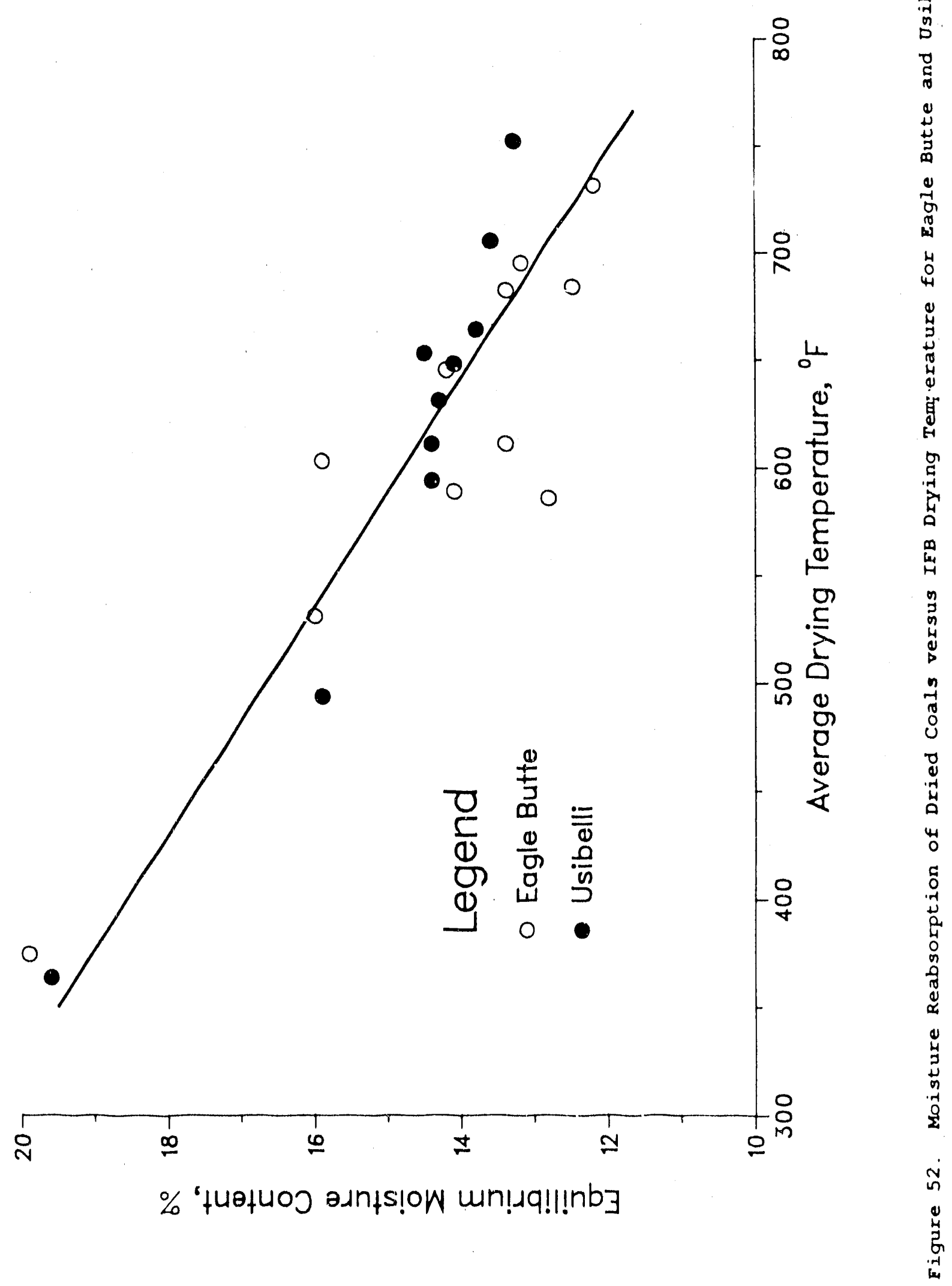


Table 22. Reabsorption of Moisture by Eagle Butte and Usibelli Coals at Varied Relative Humidity

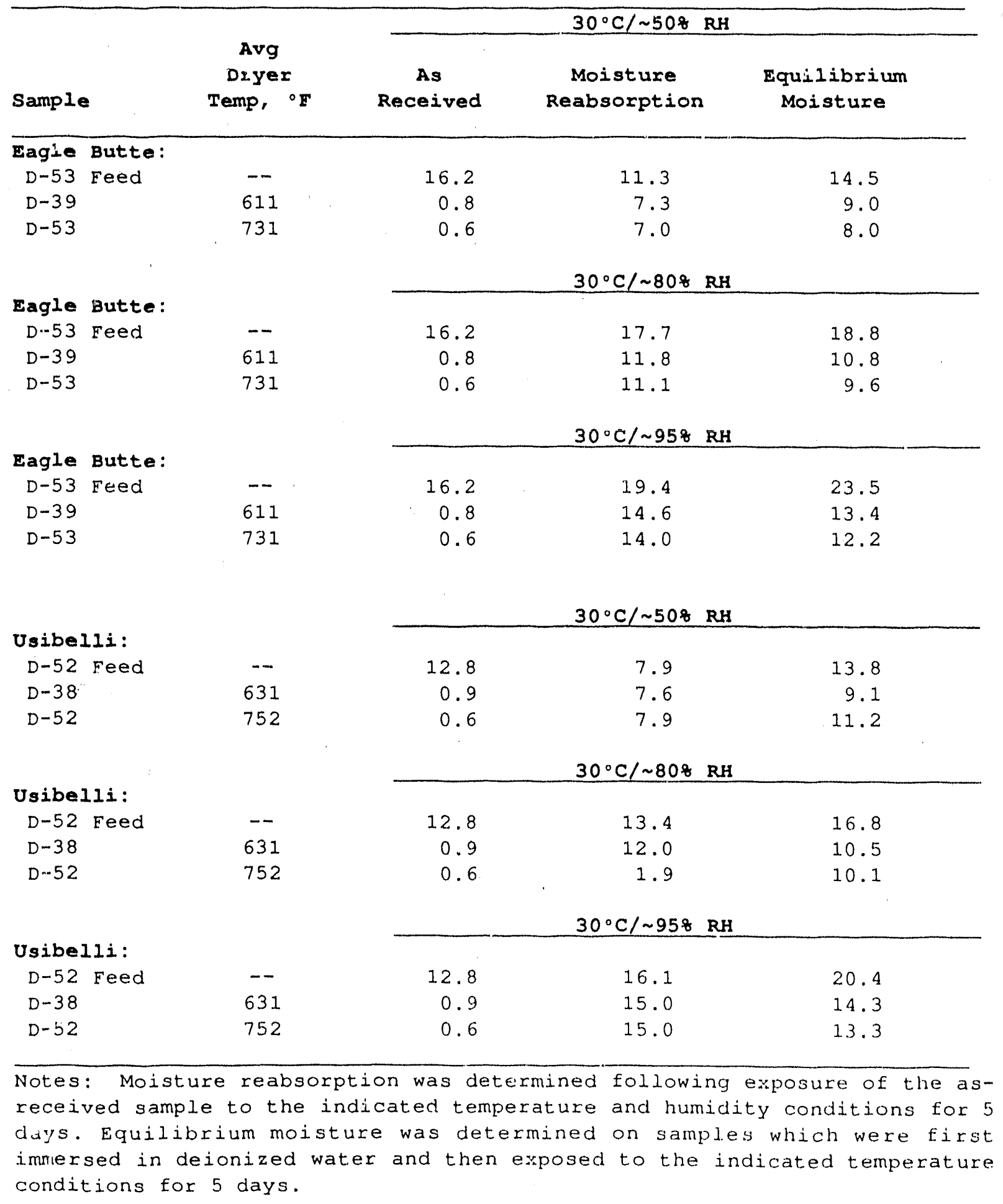


These compare to values of 12 to 15 percent under 958 humidity conditions. Similarly, the dried Usibelii coals exhibited moisture re absorption and equilibrium moisture values between about 8 and 1 i percent at 508 relative humidity compared to values between 13 and $1 j$ percent at $95 \%$ relative humidity. Even lower levels of moisture reabsorption would be expected at the more typical average temperature conditions (between about 10 and $20^{\circ} \mathrm{C}$ ) in the regions of the United States discugsed above.

Moisture reabsorption lests were performed on the Eagle Butte and Usibelli feed coals following convenzional oven drying at about $100^{\circ} \mathrm{C}$. Moisture reabsorption in the conven'ionaj oven dried samples (Table 23) was slightly greater (about 168) than the IFB-dried samples (typically 14-15\%). However, equilibrium moisture values of the conventional oven dried samples were significantly greater $(20-22 \%)$ than the IFB-dried coals (13-16\%). These results show that the inclined fluidized bed drying process changed coal pore structures to be more hydrophobjc than conventional oven drying.

Table 23. Moisture Reabsorption Chaxacteristics of oven-Dried Eagle Butte and Usibelli Coals.

\begin{tabular}{lccc}
\hline Sample & $\begin{array}{c}\text { Oven } \\
\text { Dried }\end{array}$ & $\begin{array}{c}\text { Moisture } \\
\text { Reabsorption }\end{array}$ & $\begin{array}{c}\text { Equilibrium } \\
\text { Moisture }\end{array}$ \\
\hline & $<1.0$ & 16.4 & 21.9 \\
Usibelii & 0.6 & 16.4 & 20.3 \\
\hline
\end{tabular}


Additional moisture reatsorption tests were also performed on dried coal briquettes prepared at WRI from dried Eagle Butte and Usibelli coals. Table 24 summarizes the results. Due to limited sample availability, a single briquette (apout 1.5-inches diameter) of each coal type was broken to perform both the moisture reabsorption and equilibrium moisture measurements. Although an attempt was made to prepare two large segments from each briquette, some additional breakage occurred. As a result, additional surface area was created. The briquettes exhibited reduced moisture reabsorption shown in rable 24 when compared to the powdered, dried coals shown in Table 21 and 22 . Still lower levels of moisture reabsorption would be expected when testing unbroken large briquettes.

Table 24. Moistuxe Reabsorption Characteristics of Dried and Compressed Eagle Butte and Usibelli Coal Briquettes

\begin{tabular}{lccc}
\hline & \multicolumn{1}{c}{$\begin{array}{c}\text { Moisture Content, Wt } 8 \\
\text { Sample }\end{array}$} & $\begin{array}{c}\text { Moistu=e } \\
\text { Reabsorption } \\
\text { Received }\end{array}$ & $\begin{array}{c}\text { Equilibrium } \\
\text { Moisture }\end{array}$ \\
\hline Eagle Butte & $<1.3$ & 12.1 & 10.9 \\
Usibelij & 0.8 & 12.0 & 10.1 \\
\hline
\end{tabular}


Subtask 4.2--Dust Formation

Dust formation tests were conducted on selected samples corresponding to those used for moisture reabsorption and spontaneous heating evaluations and on all 12-hour drying test products. Tables 25 and 26 summarize these results. The test results are compared by noting the level of light transmission in an opacity meter at elapsed times of 15 and 60 seconds. This provides a relative indication of the level of dustiness for each sample. (Greater light transmission indicates lower dust levels.)

The test results confirmed that the dried coal products contained very low levels of dust compared to the feed coals. In general, the dried Usibelli coal samples exhibited lower dust levels than the dried Eagle Butte coal samples. Lower moisture contents in the feed coals led to greater amounts of dust generation, particularly for the Eagle Butte coal. 
Table 25. Opacity Meter Measurements of Eagle Butte Coal Feeds and Dried Products

\begin{tabular}{|c|c|c|c|}
\hline Sample & \& Moisture & $\begin{array}{l}\text { Light Transmission, } \\
0.25 \text { minute }\end{array}$ & $\begin{array}{l}\text { o at } t= \\
1.0 \text { minute }\end{array}$ \\
\hline Eagle Butte Feed & 27.7 & 16 & 28 \\
\hline$D-39$ Feed & 19.7 & 6 & 11 \\
\hline$D-45$ Feed & 26.9 & 26 & 41 \\
\hline D-53 Feed & 16.2 & 5 & 8 \\
\hline$D-2$ & 2.6 & 99 & 100 \\
\hline$D-8$ & 0.1 & 96 & 100 \\
\hline$D-14$ & 0.5 & 95 & 98 \\
\hline$D-30$ & 0.6 & 100 & 100 \\
\hline $5-31$ & 0.3 & 98 & 99 \\
\hline$D-37$ & 0.9 & 95 & 98 \\
\hline$D-39$ & 0.8 & 75 & 85 \\
\hline$D-41$ & 0.7 & 75 & 86 \\
\hline$D-45$ & 1.0 & 92 & 95 \\
\hline$D-47$ & 0.7 & 74 & 86 \\
\hline$D-49$ & 0.4 & 95 & 97 \\
\hline$D-51$ & 1.0 & 65 & 81 \\
\hline$D-53$ & 0.6 & 76 & 88 \\
\hline
\end{tabular}

Table 26. Opacity Meter Measurements cf Usibelli Coal Feeds and Dried Products

\begin{tabular}{|c|c|c|c|}
\hline Sample & \& Moisture & $\begin{array}{l}\text { Light Transmission, } \\
0.25 \text { minutc }\end{array}$ & $\begin{array}{l}8 \text { at } t= \\
1.0 \text { minute }\end{array}$ \\
\hline Usittelli Feed & 20.3 & 26 & 59 \\
\hline$D-38$ Feed & 14.3 & 24 & 49 \\
\hline D-44 Feed & 15.9 & 16 & 41 \\
\hline D-52 Feed & 12.8 & 20 & 49 \\
\hline$D-17$ & 0.6 & 99 & 100 \\
\hline$D-22$ & 0.3 & 99 & 100 \\
\hline$D-29$ & 0.7 & 99 & 100 \\
\hline$D-32$ & 0.1 & 99 & 100 \\
\hline$D-35$ & 0.7 & 100 & 100 \\
\hline$D-36$ & 0.8 & 100 & 100 \\
\hline$D-38$ & 0.9 & 100 & 100 \\
\hline$D-43$ & 0.4 & 95 & 98 \\
\hline$D-46$ & 0.5 & 95 & 99 \\
\hline$D-18$ & 0.3 & 100 & 100 \\
\hline$D-50$ & 0.6 & 95 & 100 \\
\hline$D-52$ & 0.5 & 95 & 99 \\
\hline
\end{tabular}


Subtask 4.3--Spontaneous Heating

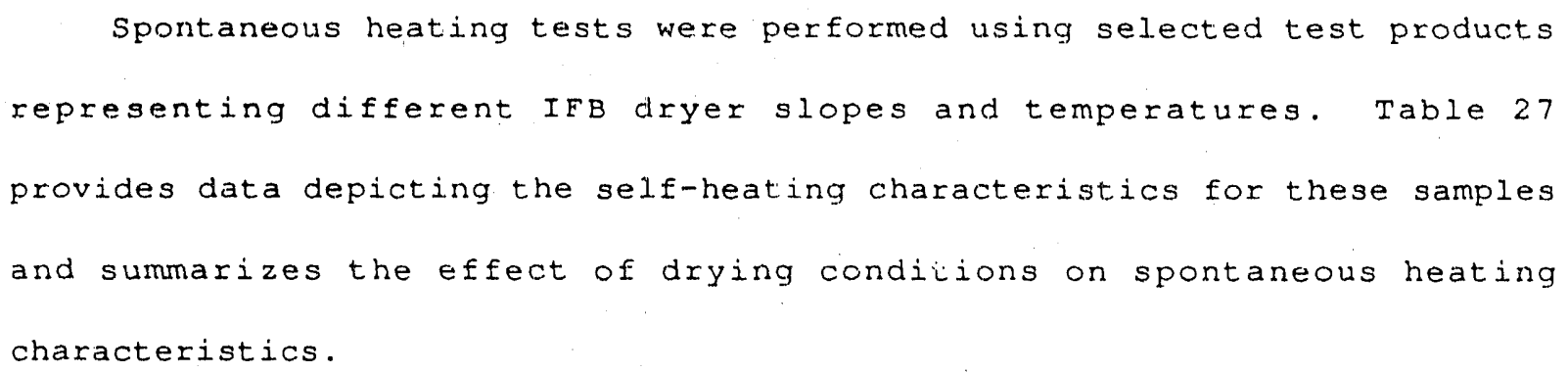

spontaneous heating tests were run under the following standard conditions: $70^{\circ} \mathrm{C}$ starting temperature; $160 \mathrm{~cm}^{3} / \mathrm{min} \mathrm{O}_{2}$ saturated with moisture. When the sample began to ignite or when the bed temperature reached $300^{\circ} \mathrm{C}$ testing stopped. The amount of time required for the sample to ignite was recorded ard compared to results obtained for other samples.

Table 27. Effect of Drying Conditions on Self-Heating Characteristics

\begin{tabular}{|c|c|c|c|c|c|}
\hline Coal Type & $\begin{array}{l}\text { Test } \\
\text { Numb: } 5\end{array}$ & $\begin{array}{l}\text { Reactor } \\
\text { Slope }\end{array}$ & $\begin{array}{l}\text { Drying } \\
\text { temp, }{ }^{\circ} \mathrm{F}\end{array}$ & $\begin{array}{l}\text { Sample } \\
\text { Location }\end{array}$ & $\begin{array}{l}\text { Self-heating } \\
\text { Time, min, } \\
\text { to reach } \\
200^{\circ} \mathrm{C}\end{array}$ \\
\hline \multirow[t]{6}{*}{ Eagle Butte } & -- & -- & -- & Avg. Feed & 160 \\
\hline & $D-2$ & 3 & 586 & Product & 145 \\
\hline & $D-30$ & 3 & 531 & Eroduct & 70 \\
\hline & $D-31$ & 3 & 695 & Product & 45 \\
\hline & $D-39$ & 9 & 611 & Product & 75 \\
\hline & $D-53$ & 15 & 731 & Product & 60 \\
\hline \multirow[t]{7}{*}{ Usibelli } & -- & -- & - & Avg Feed & $>150$ \\
\hline & $D-29$ & 3 & 494 & Eroduct & 130 \\
\hline & $D-32$ & 3 & 705 & Product & 40 \\
\hline & $D-35$ & 3 & 611 & Product & 75 \\
\hline & $D-36$ & 6 & 664 & Eroduct & 52 \\
\hline & $D-38$ & 9 & 631 & Product & 60 \\
\hline & $D-52$ & 15 & 752 & product & 50 \\
\hline
\end{tabular}


spontaneous heating tests indicated that the feed coals were the most stable in terms of self-heating. The feed roals also exhibited relatively high surface area values (Table 28), although surface area alone apparently cannot be used to predict self-heating characterisiics. The higher drying temperatures generally resulted in the shorter self-heating times. Dried coal surface area may depend on the drying temperature as well as residence time. It was observed that a mild low temperature oxidation greatly reduces the spontaneous heating tendency. Therefore, spontaneous heating may not cause any serious problems for handling dried coal. Spontaneous heating test results strongly suggest that combustion characteristics of coal are much improved through drying.

Subtask 4.4--Surface Treatments

Surface area and particle density determinations were performed on selected Eagle Butte and Usibelli feeds, products, and fines samples. Table 28 summarizes the results. Two sets of feed, product, and fines samples representing the two coal types, different dryer reactor slopes, and different drying temperatures were analyzed. In general, the surface areas of the products were observed to be somewhat lower than the feed coals. Reduction in the surface area was probably caused by plugging of pores by tar generated from coal pyrolysis. The entrained fines generally exhibited lower surface area than either the feed or the dried products. The Eagle Eutte coal samples contained greater surface area than the Usibelli coal samples. 
Coal particle densities were determined by displacement in kerosene. The values shown in Table 28 were determined for the as-received feeds and dried coals.

The Usibelli coals exhibited greater particle density values than the Eagle Butte coals. The coal densities at their equilibrium moisture contents were similar for the feed, product, and fines samples within each coal type. The coal densities prior to reabsorbing moisture were greatest for the feed coals (which contain the greatest levels of equilibrium moisture). The lower dry coal densities exhibited by the products suggest that some change in structure takes place during drying. Removal of moisture combined with inaccessibility of pores (plugged by tars) would result in reduced particle density values.

The effect of surface treating the dried coals with oil to further stabilize them was investigated in this subtask. Only limited benefit for reducing dustiness and moisture reabsorption was achieved. The detailed results of surface treating experiments are presented in Appendix $B$. 


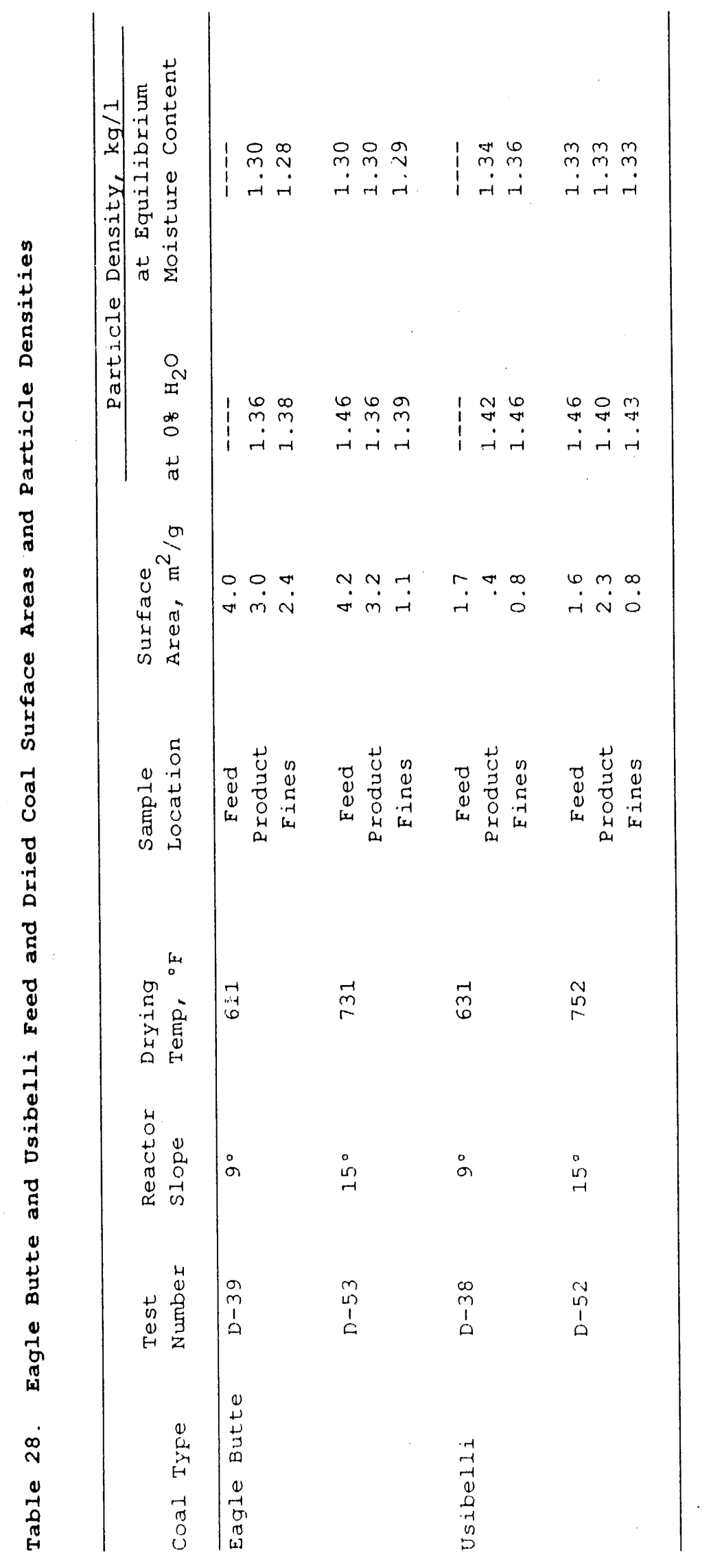


Task 5--Technical and Economic Evaluation

To assess the technical and economic potential of the IFB Coal Drying and Stabilizing process, capital and operating cost estimates for a conceptual IFB coal drying commercial plant were prepared. A preliminary economic analysis was performed using the capital and operating cost estimates and projecting a required product selling price for a fixed rate of return on investment.

The following section briefly describes the conceptual process configuration, major design and operating features, and capital and operating cost estimates for a 3000 tons per day run-of-mine coal IfB drying plant. Discussion of the methods, basis, and assumptions used are included.

\section{Conceptual Commercial IFB Drying Rlant Design}

\footnotetext{
Since the original objective of this program was to develop an IFB process for drying coal fines, the coal feed size of -28 -mesh was chosen for bench-scale tests. Later the program objective was expanded to develop the IFB process for drying and stabilizing a high moisture subbituminous coal having a mine-run particle size (2-inch). However, the coal feed size of -28-mesh is chosen for the technical and economic evaluation mainly because the experimental data were obtained from this size coal. Also dried fine coal is briquetted for handling and transportation. The equilibrium moisture and $\ldots$.ing value of briquettes made from -28 -mesh dried coal were $7.6 \%$ and $11,340 \mathrm{Btu} / \mathrm{lb}$, respectively. In future commercial operation we expect to use
} 
the mine-run size of -2-inch for the IFB process to produce a large particle size dried coal withoul briquetting operation.

We developed the configuration of a conceptual size specific mine mouth plant located at Eagle Butte mine of Amax Coal. Capital and operating costs were derived for a plus or minus 30 percent accuracy, order-of-magnitude cost estimate. The following paragraphs discuss the basis and assumptions used in developing the conceptual plant design and defining the plant components.

The plant uses a wyoming subbituminous coal (Eagle Butte) with the following composition:

Table 29. Commexcial Plant Fead Coal Composition

\begin{tabular}{lr} 
Element & Weight 8 \\
& \\
Ultimate Analysis (Moisture Free) & 67.4 \\
Carbon & 5.1 \\
Hydrogen & 0.9 \\
Nitrogen & 0.6 \\
Sulfur & 19.4 \\
Oxygen & 6.6 \\
Ash & \\
& 35.2 \\
Proximate Analysis (As Received) : & 30.9 \\
Fized Carbon & 29.2 \\
Volatile Matter & 4.7 \\
Moisture & \\
Ash & \\
\hline
\end{tabular}


The plant has a drying capacity of 3,000 ton/day of run-of-mine coal feed and produces 1,726 ton/day of dried coal briquettes. The dried coal fines (291 ton/day) entrained by gas are burned in the combustor to generate hot gas for the IFB dryers. The amount of entrained coal fines was calculated from the 12-hour test data (D-39).

We generated the data that formed the basis for defining the major equipment items in the plant, including crushing, IFB drying, combustion and heating, gas handling, and briquetting. The process flow diagram, material balance, and utility requirements were developed based on the 12hour test data (D-39). In addition to the test data, information obtained from several recent studies and projects available in-house were used to define the process stream conditions.

Figure 53 shows the plant feeds and products. Of the total 3,000 ton/day subbituminous coal received at the plant and fed to the IFB, 291 ton/day of fines are combusted to produce 4520 tons of hot gas for the operation of the primary dryers. The secondary dryers are operated using the recycled carbon dioxide produced in these dryers.

The plant's products are 1726 ton/day of briquettes made from the dried coal, 20-ton/day ash, and 5,385 ton/day stack gas. The product from the plant contains, on a heat-content basis, $81.5 \%$ cf the feed coal Btu's.

Table 30 shows the overall plant energy input and the subsequent dist abution of this energy. The results show the plant to have an overall 
thermal. efficiency of $81.2 \%$. This efficiency level is higher than those for competing processes.

Table 30. Commercial plant Thermal Efficiency

\begin{tabular}{lcr}
\hline Item & Milion Btu/hr & \& of Total Input \\
\hline Energy Input & $2100^{\mathrm{a}}$ & 99.6 \\
Total Received Coal & $9 \mathrm{~b}$ & 0.4 \\
Electric Rower & 2109 & 100.0 \\
Total Input & & \\
& & 81.2 \\
Energy Distribution & $1712^{\mathrm{c}}$ & 18.8 \\
Briquettes & 397 & \\
Consumption and Losses & 2109 &
\end{tabular}

(a) Based on as-received coal heating value of $8400 \mathrm{Btu} / \mathrm{Lb}$

(b) Based on 3,413 Btu/Kw-hr

(c) Based on estimated briquette heating value of $11,900 \mathrm{Bt}$ u/1b 


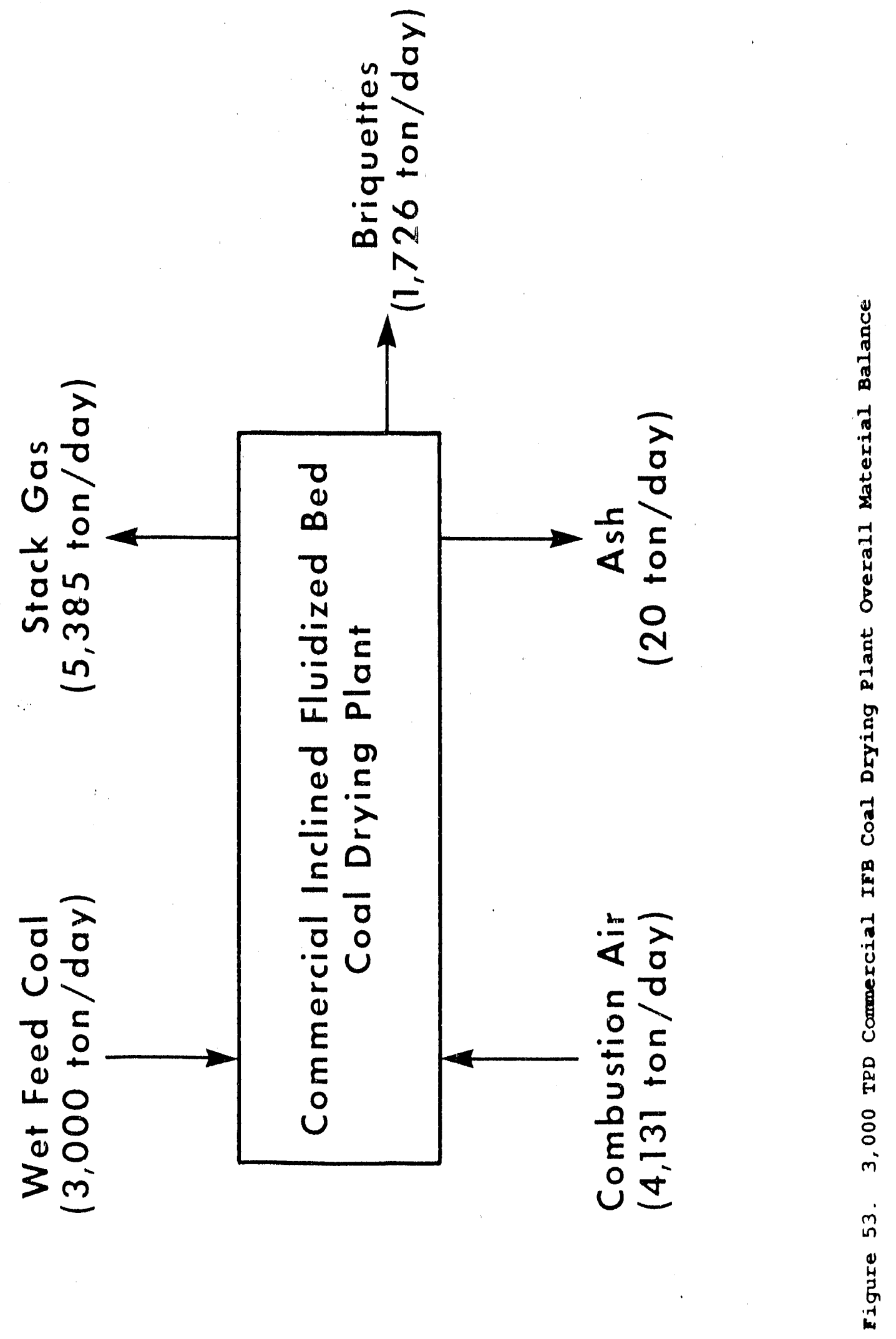


An overall process flow diagram of the plant is shown in Figure 54. Table 31 lists the composition, flowrates, and process conditions of the major process flow streams. A brief description of the processing steps shown in Figure 54 is given in the following paragraphs.

Run-of-mine coal, -2-inch, is received from an existing coal preparation plant, weighed at a belt scale $(x-100)$ and transported by conveyor $(C-100)$ to storage silo $(T-100)$. The coal is moved by the apron feeder $(\mathrm{C}-101)$ to the vibrating screen $(\mathrm{x}-102)$, oversize goes through primary roll crusher $(G-100)$, then is mixed with the undersize from the apron feeder $(C-101)$ and is fed to the secondary roll crusher (G-101). The -28-mesh coal is fed through belt scale to the feed bin $(T-200)$. This portion of the circuit from belt scale $(\mathrm{x}-100)$ to conveyor $(\mathrm{C}-102)$ is designated as the coal crushing section for cost estimation.

The crughed and sized coal is fed from feed bin $(T-200)$ through screw conveyors $(C-200)$ to lock hoppers $(T-201)$ to the inclined fluidized-bed dryers (R-200). There are four fluidized-bed dryers in parallel. Each dryer is five feet long and rated at 32 tons per hour of coal feed and 48 tons per hour of fluidizing gas. The moisture free coal exits the dryer through stream $\mathrm{S}-300$, into lock hopper (T-300). Coal enters the primary IFB dryer at $60^{\circ} \mathrm{F}\left(16^{\circ} \mathrm{C}\right)$ and exits this first bank of dryers at $380^{\circ} \mathrm{F}$ $\left(193^{\circ} \mathrm{C}\right)$. The nearly moisture-free coal enters the second bank of IFB dryers at about $380^{\circ} \mathrm{F}\left(193^{\circ} \mathrm{C}\right)$ and exits at $600^{\circ} \mathrm{F}\left(316^{\circ} \mathrm{C}\right)$. Coal feed to the first bank of dryers is 3,000 ton/day of -28 -mesh moist coal and exiting the second bank of dryers is 1,726 ton/day of dry coal. The portion of the circuit from feed bin $\mathrm{T}-200$, to stream $\mathrm{S}-301$, is designated as the drying sertion for cost estimation. 


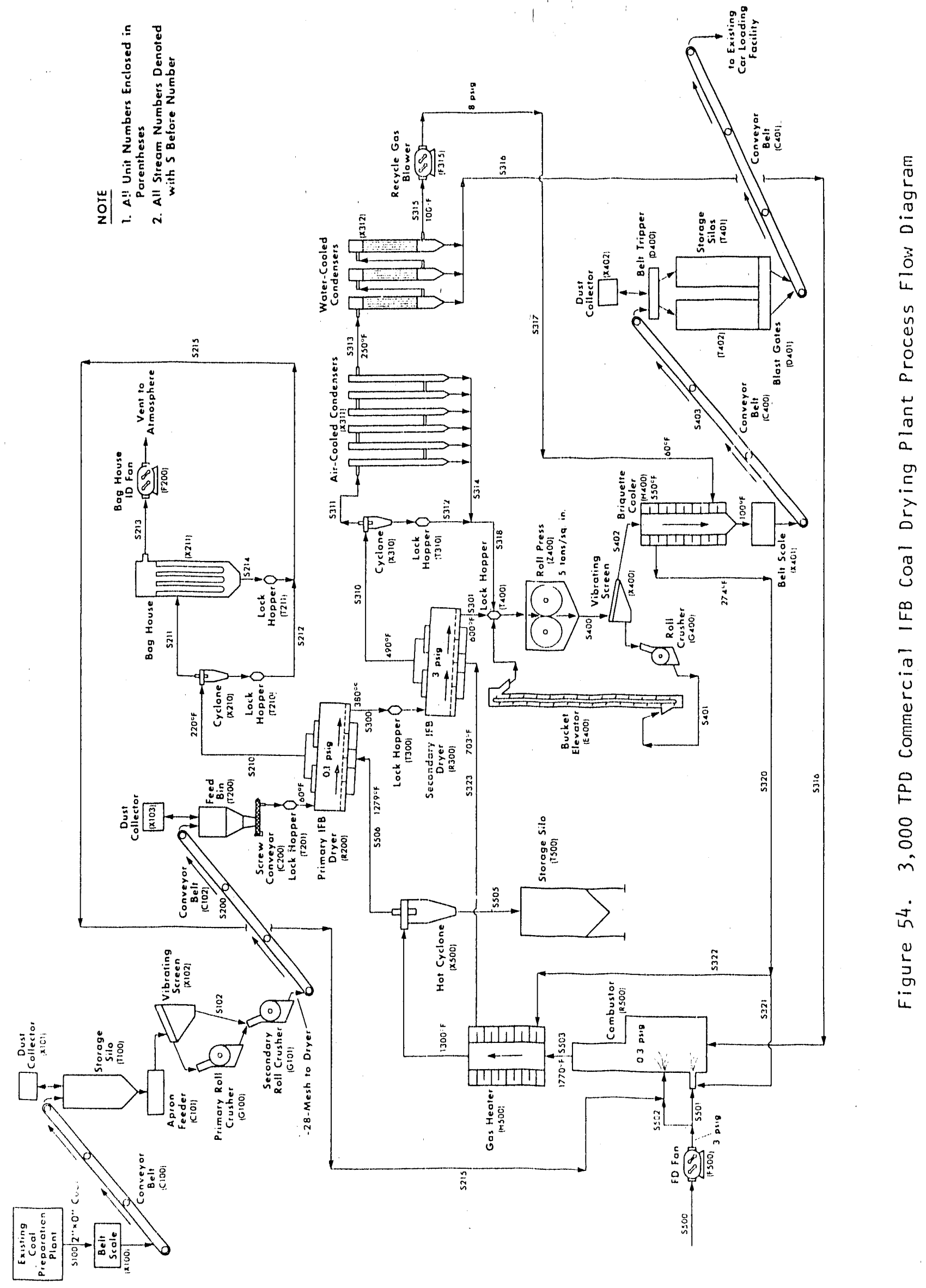


Table 31. Commercial Plant Process Stream Conditions

\begin{tabular}{|c|c|c|c|c|}
\hline $\begin{array}{c}\text { Stream } \\
\#\end{array}$ & $\begin{array}{l}\text { Flowrate, } \\
\text { ton/day }\end{array}$ & $\begin{array}{c}\text { Temperature, } \\
\text { F }\end{array}$ & $\begin{array}{l}\text { Pressure, } \\
\text { psig }\end{array}$ & $\begin{array}{c}\text { Sensible } \\
\text { and Latent } \\
\text { Heat, } \\
\text { mmbtu/hr }\end{array}$ \\
\hline$s-100$ & 3,000 & 60 & 0 & 0 \\
\hline$S-101$ & 2,350 & 60 & 0 & 0 \\
\hline$s-10 ?$ & 650 & 60 & 0 & 0 \\
\hline$s-200$ & 3,000 & 60 & 0 & 0 \\
\hline$s-210$ & 5,676 & 220 & 0.1 & 119.1 \\
\hline$S-211$ & 5,394 & 220 & 0 & 117.8 \\
\hline$s-212$ & 282 & 220 & 0 & 1. 3 \\
\hline$S-213$ & 5,385 & 220 & -0.3 & 117.7 \\
\hline$S-214$ & 9 & 220 & 0 & 0.1 \\
\hline$S-215$ & 291 & 200 & 0 & 1.4 \\
\hline$s-300$ & 1,824 & 380 & 0.1 & 17.0 \\
\hline$s-301$ & 1,669 & 600 & 3 & 26.3 \\
\hline$s-310$ & 4,655 & 490 & 3 & 41.9 \\
\hline$S-311$ & 4,609 & 490 & 2 & 41.3 \\
\hline$s-312$ & 46 & 490 & 0 & 0.6 \\
\hline$S-313$ & 4,598 & 250 & 1 & 1.7 .2 \\
\hline$S-314$ & 11 & 250 & 0 & 0.1 \\
\hline$S-315^{\circ}$ & 4.593 & 100 & -0.3 & 3.3 \\
\hline$s-316$ & 5 & 100 & 0 & 0.0 \\
\hline$S-317$ & 4,593 & 100 & 8 & 3.3 \\
\hline$S-318$ & $: \quad 57$ & 400 & 0 & 0.6 \\
\hline$s-319$ & 4,593 & 60 & 7 & 0.0 \\
\hline$s-320$ & 4,593 & 274 & 6 & 19.0 \\
\hline$S-321$ & 93 & 237 & 5 & 0.3 \\
\hline$s-322$ & 4,500 & 237 & 5 & 15.1 \\
\hline$s-323$ & 4,500 & 703 & 4 & 63.2 \\
\hline$S-400$ & 1,899 & 550 & 0 & 27.1 \\
\hline$S-401$ & 173 & 500 & 0 & 2.2 \\
\hline$S-402$ & 1.726 & 500 & 0 & 22.2 \\
\hline$S-403$ & 1,726 & 100 & 0 & 2.0 \\
\hline$S-500$ & 4,131 & 60 & -0.3 & 0.0 \\
\hline$S-501$ & 1,657 & 60 & 2 & 0.0 \\
\hline$S-502$ & 2,474 & 60 & 2 & 0.0 \\
\hline$S-503$ & 4,520 & 1770 & 0.3 & 225.1 \\
\hline$s-504$ & 4,520 & 1300 & 0.3 & 165.8 \\
\hline$S-505$ & 20 & 1279 & 0.2 & 0.9 \\
\hline$S-506$ & 4,500 & 1279 & 0.2 & 160.2 \\
\hline
\end{tabular}


Dry coal from the drying section is collected in lock hoppex $(\mathrm{T}-400)$. Broken recycle briquettes are added to the lock hopper. The dry coal and recycle briquettes are fed to the briquetting roll press $(2-400)$. The briquettes drop onto a screen $(\mathrm{X}-400)$ where broken parts are recovered and returned through the broken briquette crusher (G-400) and bucket elevator (E-400). Former briquettes are removed from screen $(X-400)$ and pass through the briquette cooler (H-400). The cooled stable briquettes are transferred hy conveyer $(C-400)$ to the briquette storage silos (T-401). The dry coal enters the briquetting section at $550^{\circ} \mathrm{F}\left(288^{\circ} \mathrm{C}\right)$ and enters the silo at $100^{\circ} \mathrm{F}\left(38^{\circ}\right)$. This portion of the circuit from lock hopper (T-400) to conveyor belt $(C-401)$ is designated as the briquetting section for cost estimation.

Coal fines are used to provide process heat. The fines from stream S215 are mixed with combustion ais stream (s-502) and injected into the combustor $(R-500)$. Recycle gas stream $(S-321)$ is mixed with combustion air stream (S-501) and injected into the combustor while recycle gas stream (S322) is heated to $705^{\circ} \mathrm{F}\left(374^{\circ} \mathrm{C}\right)$ in recycle gas heater (H-500) and then introduced into the secondary coal dryers (R-300). The combustor is fed with 291 ton/day of coal fines, 93 ton/day of recycle gas, and 4,131 ton/day of combustion air. The 4,520 ton/day of combustion products are fed through stream $\mathrm{s}-503$, to recycle gas heater $(\mathrm{H}-500)$, then through stream S-504, to hot cyclone $(x-500)$. Exiting the cyclone is 4500 ton/day of hot gas, $1279^{\circ} \mathrm{F}\left(693^{\circ} \mathrm{C}\right)$, through stream s-506, and 20 ton/day of ash through stream S-505 to fly ash storage silo (T-500). Recycle gas (4,500 ton/day) is fed through the gas heater $(H-500)$ and its temperature is increased from 237 to $703^{\circ} \mathrm{F}\left(114\right.$ to $\left.373^{\circ} \mathrm{C}\right)$. This portion of the circuit is designated as the combustion and heating section for cost estimation. 
Gas exits the first IFBs (R-200) through streams $S-210$ and passes through cyclone $(x-210)$ and bag house $(x-211)$. Coal fines are collected from the cyclone and bag house and returned to the combustor in stream s215. The moisture laden gas stream is vented through stream $5-213$. The gas handling and fines recovery from first IFB dryer is designated the vent gas provessing section for cost estimation.

Gas exits the second IFB $(R-300)$ through the stream $S-310$. This stream (4655 ton/day) passes through cyclone $(x-310)$. The overflow from the cyclone is initially cooled from 490 to $250^{\circ} \mathrm{F}$ (254 to $121^{\circ} \mathrm{C}$ ) in air cooled condensers $(x-311)$. The recycle gas is cooled to $100^{\circ} \mathrm{F}\left(38^{\circ} \mathrm{C}\right)$ in water cooled condenser $(x-312)$. Gas stream $s-315$ (4593 ton/day) is passed through recycle gas blower $(F-315)$ for use in the briquette cooler and then recycled. This gas handing section, down stream of the second IFB, is designated the recycle gas processing section for cost estimation.

\section{Capital Cost ratimate}

Major equipment items shown in the proces flow diagram (Figure 54) were identified and sized using the information given in Table 31 . Table 32 gives a list of major equipment with their descriptions. Cost estimates for each of the items in Table 32 were obtained from the sources indicated in Table 33. The cost estimates were adjusted to scale and to third quarter, 1989 (Q3/89) dollars using the factors shown in Table 34 . The estimated equipment costs for the commercial plant. shown in Table 35 were obtained on an installed or equipment only basis. All items in the crushing and screening sections of the plant were obtained on an installed basis. 
Table 32. Descriptive Capital Equipment List

\section{Eqt. \# \# REQ. DESCRIPTION:}

\section{COAL CRUSHING:}

\begin{tabular}{|c|c|c|}
\hline C100 & 1 & $\begin{array}{l}\text { Transport Conveyor: } 500 \mathrm{tph} \text { capacity, } 36 \mathrm{in} \text {. } \\
\text { widtl, } 500 \mathrm{ft} \text {. long, } 140 \mathrm{ft} \text {. vertical lift (16 } \\
\text { degree angle), } 100 \mathrm{hp} \text { drive motor. }\end{array}$ \\
\hline $\mathrm{C} 101$ & 1 & $\begin{array}{l}\text { Apron Feeder: } 250 \mathrm{tph} \text { capacity, } 20 \mathrm{hp} \text { drive } \\
\text { motor. }\end{array}$ \\
\hline $\mathrm{C} 102$ & 1 & $\begin{array}{l}\text { Feed Conveyor: } 250 \mathrm{tph} \text { capacity, } 24 \mathrm{in.} \text { width, } \\
300 \mathrm{ft} . \text { long, } 100 \mathrm{ft} \text {. vertical lift (18 degree } \\
\text { angle), } 40 \mathrm{hp} \mathrm{drive} \mathrm{motor.}\end{array}$ \\
\hline G]กO & 1 & $\begin{array}{l}\text { Primary Roll Crusher: } 200 \mathrm{tph} \text { capacity, } 40 \text { in. } \\
\text { rolls, } 12 \mathrm{in.} \text { diameter ru1lg, } 1 / 4 \mathrm{in.} \text {. product } \\
\text { size, } 100 \mathrm{hp} \text {. }\end{array}$ \\
\hline G101 & 1 & $\begin{array}{l}\text { Secondary Roll Crusher: } 250 \mathrm{tph} \text { capacity, } 40 \\
\text { in. rolls, } 12 \text { in. diameter rolls, } 28 \text {-mesh } \\
\text { product size, } 100 \mathrm{hp} \text {. }\end{array}$ \\
\hline $\mathrm{T} 100$ & 1 & $\begin{array}{l}\text { Storage silo: } 3000 \text { tons capacity }\left(120,000 \mathrm{ft}^{3}\right) \text {, } \\
\text { conbrete construction, } 140 \mathrm{ft} \text {. high }(100 \mathrm{ft} . \\
\text { usable height), } 40 \mathrm{ft} \text {. diameter. }\end{array}$ \\
\hline$\times 100$ & 1 & Peit Scale for transport conveyor C100. \\
\hline$x 101$ & 1 & $\begin{array}{l}\text { Dust collector for transport conveyor cloo: } \\
2,000 \text { acfm blower, } 10 \mathrm{hp} \text { blower drive motor. }\end{array}$ \\
\hline$\times 102$ & 1 & $\begin{array}{l}\text { Vibrating screen: } 250 \mathrm{tph} \text { capacity, single } \\
\text { deck, } 1 / 4 \text { in screen, screen size }-15 \mathrm{ft} . \times 10 \\
\mathrm{ft.}\left(150 \mathrm{ft}^{2}\right), 20 \mathrm{hp} \text { drive motor. }\end{array}$ \\
\hline$\times 103$ & 1 & $\begin{array}{l}\text { Dust collector for feed conveyor c102: } 10,000 \\
\text { a.:fm blower, } 40 \mathrm{hp} \text { blower drive motor. }\end{array}$ \\
\hline
\end{tabular}


Table 32. Descriptive Capital Equipment list (continued) Eqt. \# \# REQ. DESCRIPTION:

COAL DRYING :

C200 4 Dryer Feed Screw Conveyors: 32 tph capacity of crushed coal with $50 \mathrm{lb} / \mathrm{ft}^{3}$ density, $18 \mathrm{in}$. screw diameter $\times 20 \mathrm{ft}$. long, horizontal configuration, carbon steel construction, $7.5 \mathrm{hp}$ drive motor, 72 rpm Class II drive.

R200 4 Primary Inclined Fluidized Bed Dryer: 32 tph solids capacity, 1 ft. thick fluidized solids bed with a bulk density $=25 \mathrm{lb} / \mathrm{ft}^{3}$, solids inlet temperature $=60 \mathrm{~F}$, solids outlet $=380 \mathrm{~F}$, fluidizing gas flow $=51,000$ acfm at gas inlet, gas inlet temperature $=1279 \mathrm{~F}$, gas outlet temperature $=220 \mathrm{~F}$, design pressure $=10$ psig, operating pressure $=.1 \mathrm{psig}, 5 \mathrm{~min}$. solids residence time, 9 degree reactor slope, stainless steel construction for fluidizing gas inlet and distributor, carbon steel construction for the remainder of the unit, $21 \mathrm{ft}$. wide, 10 ft. long, $8 \mathrm{ft}$. high.

Secondary Inclined Fluidized Bed Dryer: $20 \mathrm{tph}$ solids capacity, $1 \mathrm{ft}$. thick fluidized solids bed with a bulk density $=25 \mathrm{lb} / \mathrm{ft}^{3}$, solids inlet temperature $=380 \mathrm{~F}$, solids outlet $=600$ F, fluidizing gas flow $=28,100$ acfm at gas inlet, gas inlet temperature $=703 \mathrm{E}$, gas out let temperature $=490 \mathrm{~F}$, design pressure $=10 \mathrm{psig}$, operating pressure $=3-5 \mathrm{psig}, 5 \mathrm{~min}$. solids residence time, 9 degree reactor slope, carbon steel construction, $14 \mathrm{ft}$. wide, $10 \mathrm{ft}$. long, 8 ft. high.

Feed Hopper: 250 tons capacity $\left(10,000 \mathrm{ft}^{3}\right)$, height $=25 \mathrm{ft}$. , diameter $=24 \mathrm{ft} ., 1$ inlet, 4 outlets, carbon steel construction. 
Table 32. Descriptive Capital Equipment list (cont nued)

Eqt. \# \# REQ. DESCRIPTION:

COAL DRYING (continued):

$\mathrm{T} 201$

4

Lock Hopper: 17 cons capacity (680 $\left.\mathrm{ft}^{3}\right)$, height $=12 \mathrm{ft} .$, diameter $=9 \mathrm{ft} ., 1$ inlet $-18 \mathrm{in}$. diameter with air operated slide gate, one outlet - 18 in. diameter with air operated slide gate, carbon steel construction.

T300

4

Lock Hopper: 10 tons capacity $\left(400 \mathrm{ft}^{3}\right)$, height $=10 \mathrm{ft} .$, diameter $=8 \mathrm{ft} ., 1$ inlet $-18 \mathrm{in}$. diameter with air operated slide gate, one outlet - 18 in. diameter with air operated slide gate, carbon steel construction.

BRIQUETTING :

$\mathrm{C} 400$

1

Trunsport Conveyor: 200 tph capacity, 24 in. width, $800 \mathrm{ft}$. long, $220 \mathrm{ft}$. vertical lift (18 degree angle), $100 \mathrm{hp}$ drive motor.

$\mathrm{C} 401$

Product Loadout Conveyor: 5,000 tph capacity, $96 \mathrm{in.} \mathrm{width,} 300 \mathrm{ft}$. long, $50 \mathrm{ft}$. vertical lift (18 degree angle), 500 hp drive motor.

D 400

Belt Tripper to divert product from transport conveyor to product storage silos.

D 401

Silo Blast Gates.

E 400

1

BE104 Centrifugal Discharge Bucket Elevator: 8 tph capacity of coal briquettes with a bulk density of $35 \mathrm{lb} / \mathrm{ft}^{3}, 30 \mathrm{ft}$. lift, $3 \mathrm{hp}$ drive motor. 
Table 32. Descriptive Capital Equipment list (continued)

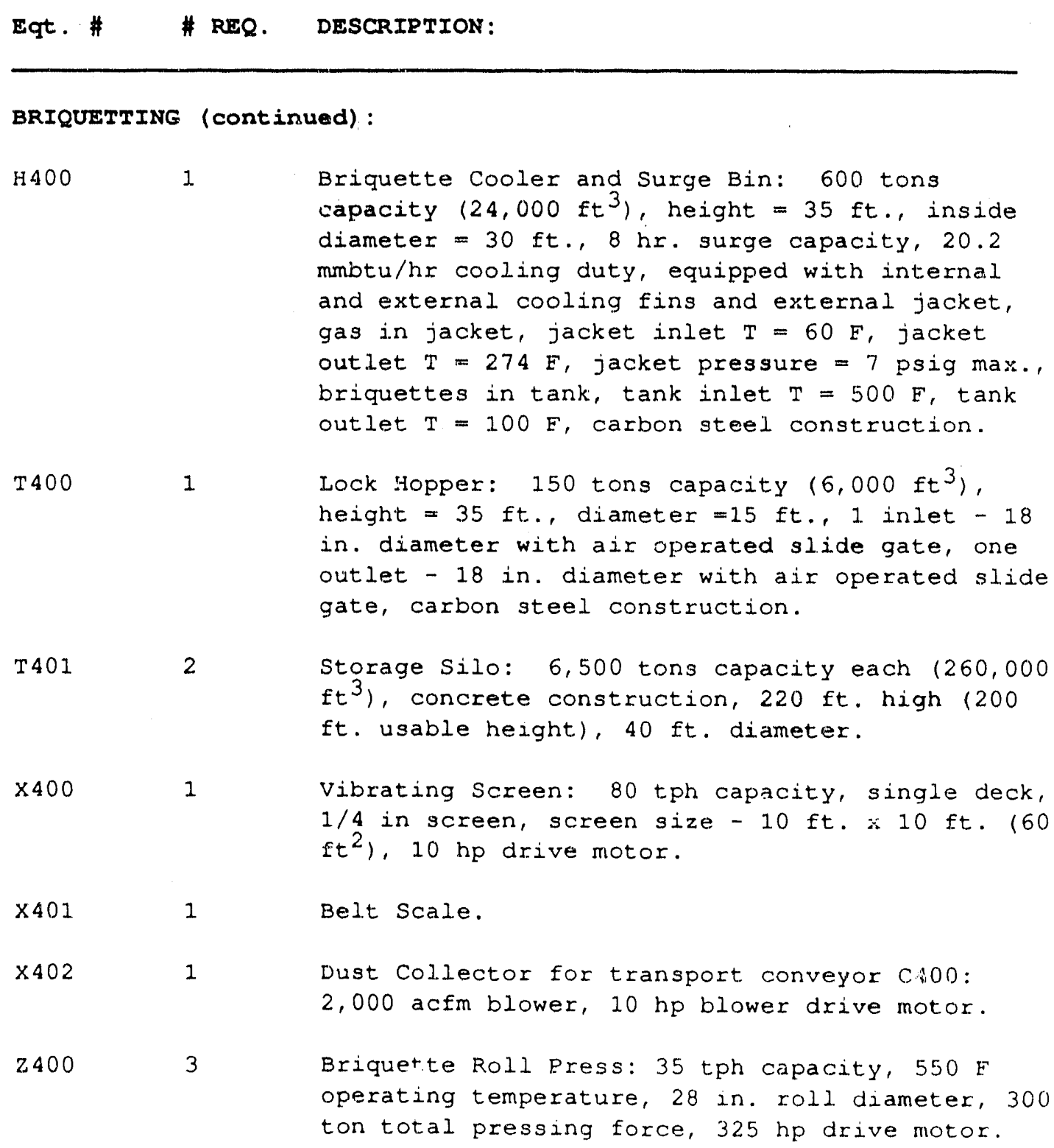

COMBUSTION AND HBATING:

F500 1 Combustor FD Fan: 78,000 acfm aif blower, $325 \mathrm{hp}$ drive motor, $P_{\text {dicharge }}=2$ psig $\max$. 
Table 32. Descriptive Capital Equipment List (continued)

Eqt. \# \# REQ. DESCRIPTION :

COMBUSTION AND HEATING (continued):

H500 1 Recycle Gas Heater: cold side; 48.1 mmbtu/hr absorbed heat duty, $\mathrm{Tin}=237 \mathrm{~F}$, Tout $=703 \mathrm{~F}$, $135,000 \mathrm{acfm}, \mathrm{dp}=2$ psi max., operating $\mathrm{P}=7$ psig. max., hot side; $59.3 \mathrm{mmbtu} / \mathrm{hr}$ heat duty, Tin $=1770 \mathrm{~F}$, Tout $=1300 \mathrm{~F}, 260,000 \mathrm{acfm}, \mathrm{dp}=$ 0.2 psi max., operating $P=0.4$ psig max.

R500 1 Entrained Solids Combustor: $225.1 \mathrm{mmbtu} / \mathrm{hr}$ heat duty, 12 tph dry coal feed, 4 tph 105 btu/scf gas feed, flue gas attemperating water $1 \mathrm{gpm}$.

T500 1 Fly Ash Storage Hopper: 40 tons capacity (1600 $\mathrm{ft}^{3}$, height $=15 \mathrm{ft}$. , diameter $=12 \mathrm{ft} ., 1$ inlet, 1 outlet, stainless steel construction.

$\times 500$

4

Hot Cyclone: 1224 acfs each at $1300 \mathrm{~F}$, solids load $=5$ tpd each, operating $\mathrm{T}=1300 \mathrm{~F}$, operating $P=2$ psig max., design $T=1400 \mathrm{~F}$, design $\mathrm{P}=10$ psig max., stainless steel construction.

VENT GAS PROCESSING:

E200 1 Bag House ID Fan: 120,000 acfm at $220 \mathrm{~F},-12$ in. of water suction pressure, $400 \mathrm{hp}$ blower drive motor.

T210 Lock Hopper: 100 tons capacity $\left(4,000 \mathrm{ft}^{3}\right)$, height $=24 \mathrm{ft}$. , diameter $=15 \mathrm{ft} ., 4$ inlets $18 \mathrm{in}$. diameter with air operated slide gate, one outlet - $18 \mathrm{in}$. diameter with air operated slide gate, carbon steel construction.

T211 Lock Hopper: 3 tons capacity $\left(120 \mathrm{ft}^{3}\right)$, height $=8 \mathrm{it}$. , diameter $=5 \mathrm{ft} ., 1$ inlet $-18 \mathrm{in}$. diameter with air operated slide gate, one outlet - 18 in. diameser with air operated slide gate, carbon steel construction. 
Table 32. Descriptive Capital Equipment Iist (continued)

Eqt. \# \# REQ. DESCRIPTION:

VENT GAS PROCESSING (continued):

X210 4 Dryer Cyclone: 375 acfs gas each, load 12 tph, operating $\mathrm{T}=220 \mathrm{~F}$, operating $\mathrm{P}=0.2 \mathrm{psig}$ max., design $T=350 \mathrm{~F}$, design $\mathrm{P}=10$ psig max. carbon steel construction.

X211 Bag House: 120,000 acfm gas total, gas temperature $=220 \mathrm{~F}$, pressure $=12$ in. of water vacuum, less than $2.0 \mathrm{tph}$ solids load, pulse jet 5 to 1.

RECYCIE GAS PROCESSING:

F315 5 Recycle Gas Blower: 14,058 acfm capacity each, $\mathrm{P}_{\text {discharge }}=8$ psig., $400 \mathrm{hp}$ blower drive motor.

$\mathrm{T} 310$

1 Lock Hopper: 17 tons capacity (680 $\left.\mathrm{ft}^{3}\right)$, height $=12 \mathrm{ft}$. , diameter $=9 \mathrm{ft} ., 4$ inlets $-18 \mathrm{in}$. diameter with air operated slide gate, one outlet - 18 in. diameter with air operated slide gate, carbon steel construction.

$\times 310$

4

Dryer Cyclone: 575 acfs gas total, solids load 2 tph, operating $T=490 \mathrm{~F}$, operating $\mathrm{P}=3 \mathrm{psig}$ max., design $T=750 \mathrm{~F}$, design $P=10$ psig max., carbon steel construction.

$\times 311$

1

Air Cooled Condensers: $24.1 \mathrm{mmbtu} / \mathrm{hr}$ cooling duty, $110,000 \mathrm{acfm}, \mathrm{T}$ in $=490 \mathrm{~F}$, Tout $=250 \mathrm{~F}$.

$\times 312$

1

Water Cooled Condensers: $13.9 \mathrm{mmbtu} / \mathrm{hr}$ cooling duty, $83,000 \mathrm{acfm}, \operatorname{Tin}=250 \mathrm{~F}$, Tout $=100 \mathrm{~F}$. 
1. Fax Memo, dated 1/8/90, from M. Berggren and $\mathbf{F}$. Hogsett of AMAX R\&D Golden, Co.

2. Fax Merno, dated 1/8/90, from F. Tidwell of Industrial Screw Conveyors, Inc. Burleson, TX.

3. Economic Evaluation of Advanced Continuous Mild Coal Gasification Process," AMAX R\&D Internal Report prepared by stearns-Roger Division of United Engineers \& Constructors, Inc., 1988.

4. WRI estimates, 1/4/90, by J. Boysen based on best available dats and data from sources 1 and 3 .

5. Phone quote, $12 / 6 / 89$, to C. Porter from M. White of BEPE Corp, Minneapolis, MN.

6. Fax Memo, 1/12/90, from D. Altman of ENSCO, Inc., Denver, CO.

7. Phone Quote, 1/10/90, to C.Y. Cha from Dr. M. Greaves, Denver, CO. 
Table 34. Estimated Capital Equipment Cost Scale Factors

\begin{tabular}{|c|c|c|c|c|c|}
\hline $\begin{array}{c}\text { Eqt } \\
\#\end{array}$ & Name (\# req.) & $\begin{array}{r}\text { Scale } \\
\text { Factor }\end{array}$ & $\begin{array}{l}\text { Marshall \& } \\
\text { Index (all } \\
\text { Q3/89 }\end{array}$ & $\begin{array}{l}\text { Swift } \\
\text { Ind.) } \\
1988\end{array}$ & $\begin{array}{l}\text { Insti: } \\
\text { Factor }\end{array}$ \\
\hline CRUSH & IING \& SCREENING SECTION: & & & & \\
\hline C100 & Transport Conveyor (1) & -- & -- & -- & -- \\
\hline C101 & Apron Feeder (1) & -- & -- & -- & -- \\
\hline C102 & Feed Conveyor (1) & -- & -- & -- & -- \\
\hline G100 & Pri. Roll Crusher (1) & -- & -- & -- & -- \\
\hline G101 & Sec. Roll Crusher (1) & -- & -- & -- & -- \\
\hline T1 100 & Storage Silo (1) & -- & $-\cdots$ & -- & -- \\
\hline$x 100$ & Belt scale (1) & -- & -- & -- & -- \\
\hline$\times 101$ & Dust Collector (1) & -- & -- & -- & -- \\
\hline$\times 102$ & Vibrating Screen (I) & -- & -- & -- & -- \\
\hline$\times 103$ & Dust Collector (1) & -- & -- & -- & -- \\
\hline COAL & DRYING SECTION: & & & & \\
\hline $\mathrm{C} 200$ & Dryer Fd. Screws (4) & -- & -- & -- & 1.00 \\
\hline $\mathrm{R} 200$ & Pri. IFB Dryer (4) & -- & 897 & 852 & 1.00 \\
\hline R.300 & Sec. IFB Dryer (4) & 0.75 & 897 & 852 & 1.00 \\
\hline $\mathrm{T} 200$ & Feed Hopper (1) & -- & -- & -- & -- \\
\hline T201 & Lock Hopper (4) & 0.65 & 897 & 852 & 1.00 \\
\hline T300 & Lock Hopper (4) & 0.65 & 897 & 852 & 1.00 \\
\hline
\end{tabular}


Table 34. Estimated Capital Equipment Cost Scale Factors (continued)

\begin{tabular}{|c|c|c|c|c|c|}
\hline$\underset{\#}{E q t .}$ & Name (\# req.) & $\begin{array}{r}\text { Scale } \\
\text { Factor }\end{array}$ & $\begin{array}{l}\text { Marshali\& } \\
\text { Index (al1 } \\
\text { Q3/89 }\end{array}$ & $\begin{array}{l}\text { Swift } \\
\text { Ind.) } \\
1988\end{array}$ & $\begin{array}{l}\text { Inst } 1 . \\
\text { Factor }\end{array}$ \\
\hline BRIQU & ETTING SECTION: & & & & \\
\hline $\mathrm{C} 400$ & Transport Conveyor (1) & -- & -- & -- & -- \\
\hline C401 & Product Conveyor (1) & -- & -- & -- & -- \\
\hline D 400 & Belt Tripper (1) & -- & -- & -- & -- \\
\hline D 401 & Silo Blast Gates & -- & -- & - - & -- \\
\hline $\mathrm{E} 400$ & Bucket Elevator (1) & -- & -- & -- & 1.00 \\
\hline G400 & Briquette Crusher (1) & 0.65 & -- & -- & -- \\
\hline $\mathrm{H} 40 \mathrm{O}$ & Briquette Cooler (1) & 0.65 & -- & -- & 1.00 \\
\hline $\mathrm{T} 400$ & Lock Hopper (1) & 0.65 & 897 & 852 & 1.00 \\
\hline T401 & Prod. Stor. Silo (2) & -- & -- & -- & -- \\
\hline$\times 400$ & Vibrating screen (1) & 0.65 & -- & -- & -- \\
\hline$\times 401$ & Belt scale (1) & -- & -- & -- & -- \\
\hline$\times 402$ & Dust Collector (1) & -- & -- & -- & -- \\
\hline 2400 & Briquette Press (1) & -- & -- & -- & 0.50 \\
\hline
\end{tabular}

COMBUSTION AND HEATING:

F500 Combustor FD Fan (1)

H500 Recycle Gas Heater (1)

$\begin{array}{llll}0.85 & 897 & 852 & 1.00\end{array}$

K500 Combustor (1)

T500 Fly Ash Hopper (1)

X500 Hot Cyclone (4)

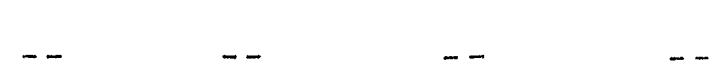

$0.65 \quad \ldots \quad \ldots \quad \ldots \quad 1.00$

$\begin{array}{llll}0.80 & 897 & 852 & 1.00\end{array}$ 
Table 34. Estimated Capital Equipment Cost Scale Factors (continued)

\begin{tabular}{|c|c|c|c|c|c|}
\hline$\underset{\#}{\text { Eqt. }}$ & Name (\# req:) & Scale & $\begin{array}{l}\text { Marshall \& } \\
\text { Index (a11 } \\
23 / 89\end{array}$ & $\begin{array}{l}\text { Swift } \\
\text { Ind. ) } \\
1988\end{array}$ & $\begin{array}{l}\text { Instl. } \\
\text { Factor }\end{array}$ \\
\hline VENT & GAS PROCESSING: & & & & \\
\hline $\mathrm{F} 200$ & Bag House ID Fan (I) & -- & -- & -- & -- \\
\hline $\mathrm{T} 210$ & Lock Hopper (1) & 0.65 & 897 & 852 & 1.00 \\
\hline $\mathrm{T} 211$ & Lock Hopper (1) & 0.65 & 897 & 852 & 1.00 \\
\hline$\times 210$ & Dryer Cyclone (4) & 0.80 & 897 & 852 & 1.00 \\
\hline$x 211$ & Bag House (1) & 0.80 & 897 & 852 & 1.00 \\
\hline \multicolumn{6}{|c|}{ RECYCIE GAS PROCESSING: } \\
\hline F315 & Recycle Gas Blower (5) & 0.82 & 897 & 852 & 1.00 \\
\hline T3 310 & Lock Hopper (1) & 0.65 & 897 & 852 & 1.00 \\
\hline$\times 310$ & Dryer Cyclone (4) & 0.80 & 897 & 852 & 1.00 \\
\hline$\times 311$ & Air Cooled Cond. (1) & 0.80 & 897 & 852 & 1.00 \\
\hline$\times 312$ & Water Cooled Cond. (1) & 0.80 & 897 & 852 & 1.00 \\
\hline
\end{tabular}


Table 35. Fistimated Capital Equipment Costs

\begin{tabular}{|c|c|c|c|c|c|c|}
\hline$\underset{\#}{\text { Eqt. }}$. & Name (\# req.) & $\begin{array}{c}\text { Eqt. } \\
\text { Cost } \\
\$ 1,000\end{array}$ & $\begin{array}{l}\text { Cost } \\
\text { Date } \\
\mathrm{m} / \mathrm{y}\end{array}$ & $\begin{array}{l}\text { Instalied } \\
\text { Eqt. Cost } \\
(9 / 89) \\
\$ 1,000\end{array}$ & $\begin{array}{l}\text { Cost } \\
\text { Source }\end{array}$ & Remark \\
\hline \multicolumn{7}{|c|}{ CRUSHING \& SCREENING SECTION: } \\
\hline $\mathrm{C} 100$ & Transport Conveyor (1) & 270 & $12 / 89$ & 0 & 1 & Installed \\
\hline C 101 & Apron Feeder (1) & 90 & $12 / 89$ & 0 & 1 & Installed \\
\hline C102 & Feed Conveyor (1) & 1.08 & $12 / 89$ & 0 & 1 & Installed \\
\hline G 100 & Pri. Roll Crusher (1) & 220 & $12 / 89$ & 0 & 1 & Installed \\
\hline G101 & Sec. Roll Crusher (1) & 220 & $12 / 89$ & 0 & 1 & Installed \\
\hline $\mathrm{T} 100$ & Storage Silo (1) & 500 & $12 / 89$ & 0 & 1 & Installed \\
\hline$\times 100$ & Belt scale (1) & 20 & $12 / 89$ & 0 & 1 & Installed \\
\hline$\times 101$ & Dust Collector (1) & 40 & $12 / 89$ & 0 & 1 & Installed \\
\hline$\times 102$ & Vibrating Screen (1) & 120 & $12 / 89$ & 0 & 1 & Installed \\
\hline \multirow[t]{2}{*}{$\times 103$} & Dust Collector (1) & 100 & $12 / 89$ & 0 & 1 & Installed \\
\hline & $\because$ & \multicolumn{2}{|c|}{ (Subtotal) } & Installed & Cost $=$ & 0 \\
\hline COAL & DRYING SECTION: & & & & & \\
\hline $\mathrm{C} 200$ & Dryer Fd. Screws (4) & 28 & $12 / 89$ & 0 & 2 & eqt. only \\
\hline R200 & Pri. IFB Dryer (4) & 0 & 88 & 0 & 3 & eqt. only \\
\hline R300 & Sec. IFB Dryer (4) & 0 & 88 & 0 & 3 & eqt. only \\
\hline $\mathrm{T} 2.00$ & Feed Hopper (1) & 80 & $12 / 89$ & 0 & 1 & Installed \\
\hline $\mathrm{T} 201$ & Lock Hopper (4) & 0 & 88,89 & 0 & 1,3 & eqt. only \\
\hline $\mathrm{T} 300$ & Lock Hopper (4) & 0 & 88,89 & 0 & 1,3 & eqt. only \\
\hline & & ( Subto & & Installed & Cost $=$ & $\$$ \\
\hline
\end{tabular}


Table 35. Estimated Capital Equipment Costs (continued)

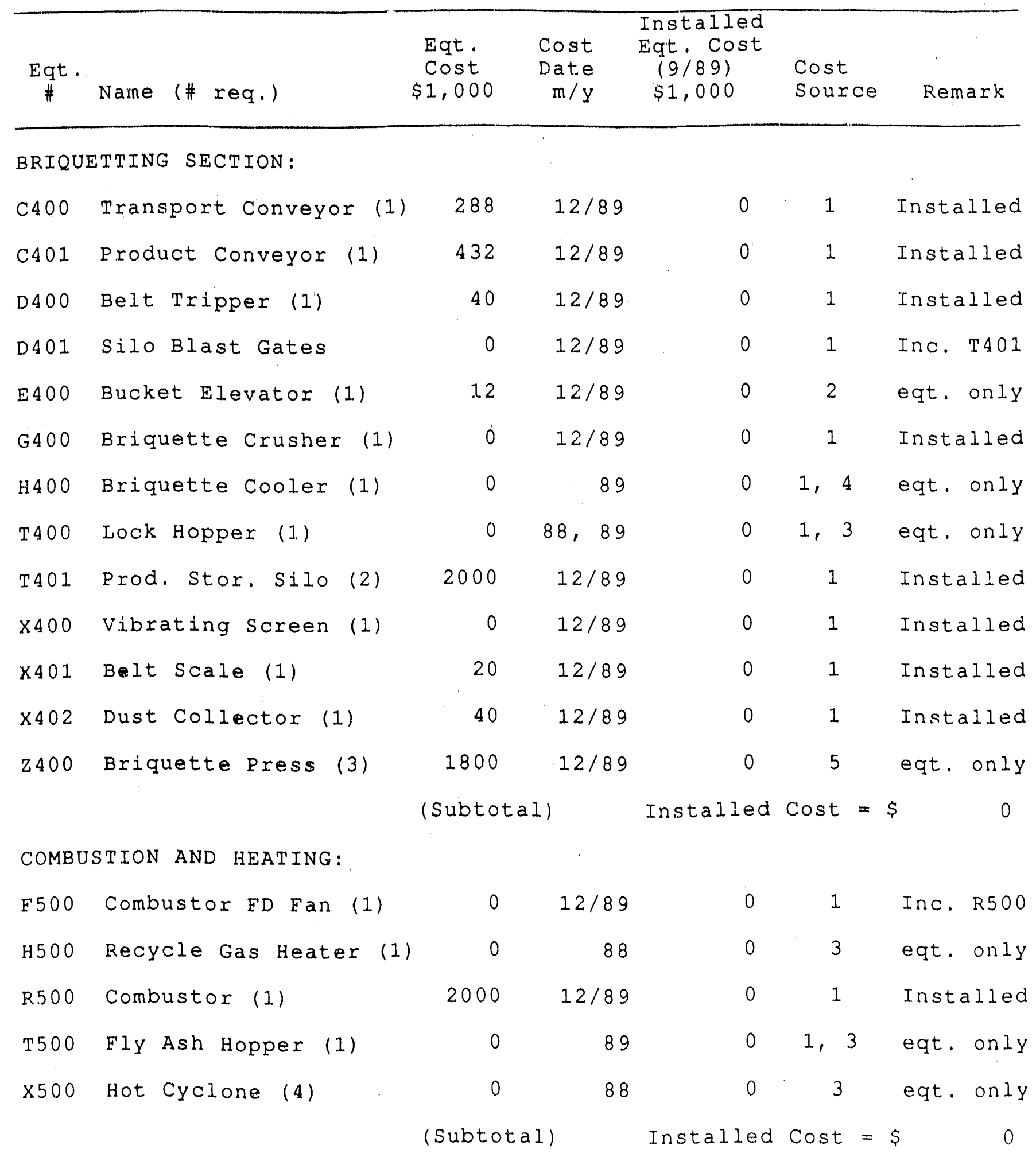


Table 35. Eutimated Capital Equipment Costs (continued)

\begin{tabular}{|c|c|c|c|c|c|c|c|}
\hline \multirow{2}{*}{$\begin{array}{c}\begin{array}{c}\text { Eqt } \\
\# \\
\text { VENT }\end{array} \\
\end{array}$} & \multirow[t]{2}{*}{ Name (\# req.) } & \multirow[t]{2}{*}{$\begin{array}{c}\text { Eqt. } \\
\text { Cost } \\
\$ 1,000\end{array}$} & \multicolumn{2}{|c|}{$\begin{array}{c}\text { Cost } \\
\text { Date } \\
m / y\end{array}$} & $\begin{array}{l}\text { Installed } \\
\text { Eqt. Cost } \\
(9 / 09) \\
\$ 1,000\end{array}$ & $\begin{array}{l}\text { Cost } \\
\text { Source }\end{array}$ & Remark \\
\hline & & & & & & & \\
\hline $\mathrm{F} 200$ & Bag louse ID Fan (1) & 0 & 12 & 189 & 0 & 1 & Inc. $\times 211$ \\
\hline $\mathrm{T} 210$ & Lock Hopper (1) & 0 & 88, & 89 & 0 & 1,3 & eqt. only \\
\hline T211 & Lock Hopper (1) & 0 & 88, & 89 & 0 & 1,3 & eqt. only \\
\hline$\times 210$ & Dryer Cyclone (4) & 0 & & 88 & 0 & 3 & eqt. only \\
\hline \multirow[t]{2}{*}{$\times 211$} & Bag House (1) & 0 & 12 & 89 & 0 & 6 & eqt. only \\
\hline & & (Subtot & & & Installed & Cost $=$ & 0 \\
\hline \multicolumn{8}{|c|}{ RECYCLE GAS PROCESSING: } \\
\hline F 315 & Recycle Gas Blower (5) & 0 & & 88 & 0 & 7 & eqt. only \\
\hline T.310 & Lock Hopper (1) & 0 & 88, & 89 & 0 & 1,3 & eqt. only \\
\hline$\times 310$ & Dryer Cyclone (4) & 0 & & 88 & 0 & 3 & eqt. only \\
\hline$\times 311$ & Air Cooled Cond. (I) & 0 & & 88 & 0 & 3 & eqt. only \\
\hline X312 & Water Cooled Cond. (1) & 0 & & 88 & 0 & 3 & eqt. only \\
\hline & & (Subto & & & Installed & Cost $=$ & 0 \\
\hline
\end{tabular}


The estimated capital cost is summarized in Table 36. The installed capital cost estimate for the equipment is 18.45 million dollars. It was assumed that the land wos available at the mine site at no cost. No additional buildings or facilities were required. It was estimated based on Amax experience that permitting required 0.2 million dollars. Engineering was estimate at 7.0 percent of the installed equipment cost. Working capital was estimated at $\$ 723,000$ (one month's operating expense). A contingency of $15 \%$ was added to the installed plant cost to give a total capital investment of $23.7 \mathrm{million}$ third quarter 1989 dollars.

Table 36. Sumary of Estimated Capital Sosts

\begin{tabular}{lc}
\hline Items & Cost, Milion \\
\hline Installed Major Lquipment Cost & 18.45 \\
Permitting & 0.20 \\
Land & 0.00 \\
Buildings and Facilities & 0.00 \\
Engineering & 1.29 \\
Installed Plant Cost & 19.94 \\
$\quad$ Contingency & 2.99 \\
$\quad$ working Capital & 0.72 \\
Total Capital Cost & 23.65 \\
& \\
$\quad$ The installet equipment cost is shown in Table 37 and graphically \\
illustrated in Fig.- 55.
\end{tabular}


Table 37. Installed Capital Equipment Cost Breakdown

\begin{tabular}{lcc}
\hline $\begin{array}{l}\text { Installed } \\
\text { Area }\end{array}$ & $\begin{array}{l}\text { Equipment Cost } \\
\text { milion doliars }\end{array}$ & $\begin{array}{c}\text { \& of Total Installed } \\
\text { Equipment Cost }\end{array}$ \\
\hline & & 9.1 \\
Crusher \& Screen & 1.688 & 27.8 \\
Drying & 5.132 & 33.5 \\
Briquetting & 6.155 & 17.5 \\
Comb \& Heat & 3.233 & 4.1 \\
Vent Gas Proc. & 0.759 & 8.0 \\
Rec. Gas Proc. & 1.485 & 100.0 \\
Total & 18.452 & \\
\hline
\end{tabular}

The briquetting section represents the single largest cost area. As shown in Table 35, the major items in the briquetting section are the storage sjlos. These silos are sized for one unit train per week. Because of the cost of the silos and the stable natire of the briquettes, a less expensive open storage option should be considered. Process options which will be considered in the future are processing large size particles, oil stabilization (ROPE 9 , and pelletization. 


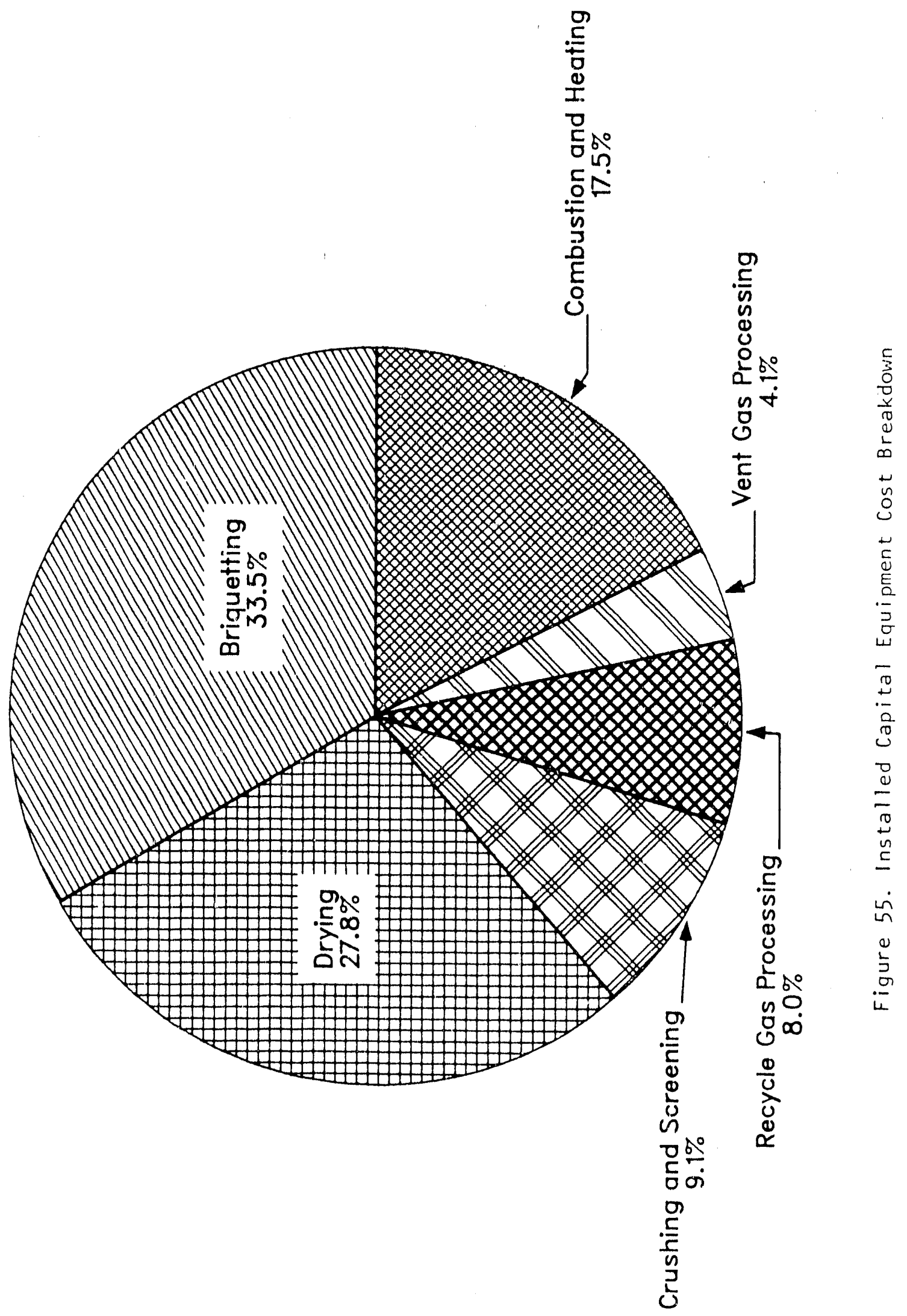




\section{Operating cost Estimate}

The annual operating cost items are sumnarized in Table 38.

Table 38. Annual Operating Cost, Million $\$ / y x$

\begin{tabular}{ll}
\hline Items & Cost \\
Coal & 4.19 \\
Maintenance & 0.28 \\
Utilities & \\
$\quad$ Electricity & 1.40 \\
$\quad$ Propane & 0.00 \\
$\quad$ Water & 0.00 \\
Opposal Costs & 0.13 \\
Royalty & 1.50 \\
Depreciation & 0.04 \\
& 1.15 \\
Total Annual Operating Costs & 8.69 \\
\hline
\end{tabular}

At a mine mouth site, in the Powder River Basin of wyoming, an average spot price of coal in the third quarter of 1989 was $\$ 4.25 /$ ton. Therefore, a coal cost of $\$ 4.25 /$ ton was used for the base case. Maintenance costs were estimated at 1.28 of the capital cost including contingency.

Utility costs were estimated for electricity, propane, and water. The annual electricity usage was estimated based on the horsepower of the major items, and the equipment load factor. The electrical usage is sumriarized in Table 39. Propane and water usage were low and estimated at $\$ 0.40 /$ gallon and $\$ 0.40$ per thousand gallons, respectively, both costs were less than $\$ 10,000.00$ annually. Disposal cost for the ash was estimated at $\$ 20 / \operatorname{ton}$. 
Table 39. Commercial Plant Electrical Useage Summary

$\begin{array}{ccc}\text { Eqt. } & & \text { Eqt. Operating Useage } \\ \# & \text { Name (\# req.) } & \text { Load hours/ mgw-hr/ } \\ & \text { Req. Factor year year }\end{array}$

CRUSHING AND SCREENING SECTION:

C100 Transport Conveyor (1)
C101 Apron Feeder (1)
C102
G100
G101
X101. Roll Crusher (1)
X102
Dust Collector (1)
X103 Dust Collector (1)

COAL DRYING SECTION:

C200 Dryer Ed. Screws (4)

BRIQUETTING SECTION:

C400 Transport Conveyor (1)
C401
E400 Bucket Elevator (1)
G400 Briquette Crusher (1)
X400 Vibrating Screen (1)
X402
D400 Bust Collector (1)

COMBUSTION AND HEATING:

F500 Combustor FD Fan (1)

VENT GAS PROCESSING:

F200 Bag House ID Fan (1)

RECYCLE GAS PROCESSING:

F315 Recycle Gas Blower (5)

X311 Air Cooled Cond. (1)

X312 Water Cooled Cond. (1)

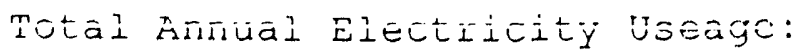

\begin{tabular}{rrrr}
100 & 0.28 & 2464 & 184 \\
20 & 0.56 & 4928 & 73 \\
40 & 0.56 & 4928 & 147 \\
100 & 0.70 & 6159 & 459 \\
100 & 0.70 & 6159 & 459 \\
10 & 0.28 & 2464 & 18 \\
20 & 0.70 & 6159 & 92 \\
40 & 0.56 & 4928 & 147 \\
\multicolumn{4}{c}{ Section subtotal: } \\
Serion
\end{tabular}

$\begin{array}{llll}30 & 0.90 \quad 7884 & 176\end{array}$

section subtotal: $\quad 176$

$\begin{array}{rrrr}100 & 0.41 & 3548 & 265 \\ 500 & 0.02 & 157 & 59 \\ 3 & 0.90 & 7884 & 18 \\ 4 & 0.90 & 7884 & 24 \\ 10 & 0.90 & 7884 & 59 \\ 10 & 0.41 & 3548 & 26 \\ 975 & 0.90 & 7884 & 5732 \\ & \text { Section subtotal: } & 6182\end{array}$

$325 \begin{array}{rrr}0.90 \quad 7884 & 1911 \\ \text { Section Subtotal: } & 191.1\end{array}$

$400 \begin{array}{rrr}0.90 \quad 7884 & 2352 \\ \text { Section subtotal: } & 2352\end{array}$

$\begin{array}{rrrr}2000 & 0.90 & 7884 & 11758 \\ 160 & 0.90 & 7884 & 941 \\ 80 & 0.90 & 7884 & 470 \\ & \text { Section Subtotal: } & 13169\end{array}$

25370 
The operating labor costs are summarized in Table 40 . This staffing assumes one engineer and five, 5-man crews. It is assumed that

business, personnel, safety, and maintenance labor is provided from the existing mining operation.

Table 40. Operating Labor Estimate for Commrcial Rlant

\begin{tabular}{|c|c|c|c|c|}
\hline Labor Category & $\begin{array}{l}\text { Base } \\
\text { Labor } \\
\text { Rates, } \\
\text { \$/hr }\end{array}$ & $\begin{array}{l}\text { Burdened } \\
\text { Labor } \\
\text { Rates, } \\
\text { \$/hr }\end{array}$ & $\begin{array}{l}\text { People } \\
\text { Required }\end{array}$ & $\begin{array}{l}\text { Annual } \\
\text { Cost, } \\
\$ / y x\end{array}$ \\
\hline Supervision & 18.32 & 25.28 & 5 & 368,100 \\
\hline Engineering & 15.27 & 21.07 & 1 & 61,363 \\
\hline Operations & 13.27 & 18.31 & $\underline{20}$ & $, 066,526$ \\
\hline Total & & & 26 & $, 495,989$ \\
\hline
\end{tabular}

It was estimated that processing royalty of 18 of the coal cost was paid for the use of the drying technology. Depreciation was calculated as straight line for the life of the plant.

The major operating cost items are presented in Table 41 and their pie chart is showing Figure 56.

rabie 11. Annual Operating Cost Breakdown

\begin{tabular}{lcr}
\hline Item & $\begin{array}{l}\text { Cost } \\
\text { \$milion/Yr }\end{array}$ & $\begin{array}{c}\text { of Annual } \\
\text { Operating Cost }\end{array}$ \\
\hline Coal & 1.970 & 39.2 \\
Maintenance & 0.280 & 5.6 \\
Electricity & 1.100 & 21.9 \\
Disposal & 0.130 & 2.6 \\
Labor & 1.500 & 29.9 \\
Royalty & 0.040 & 0.8 \\
Total & 5.020 & 100.0 \\
\end{tabular}




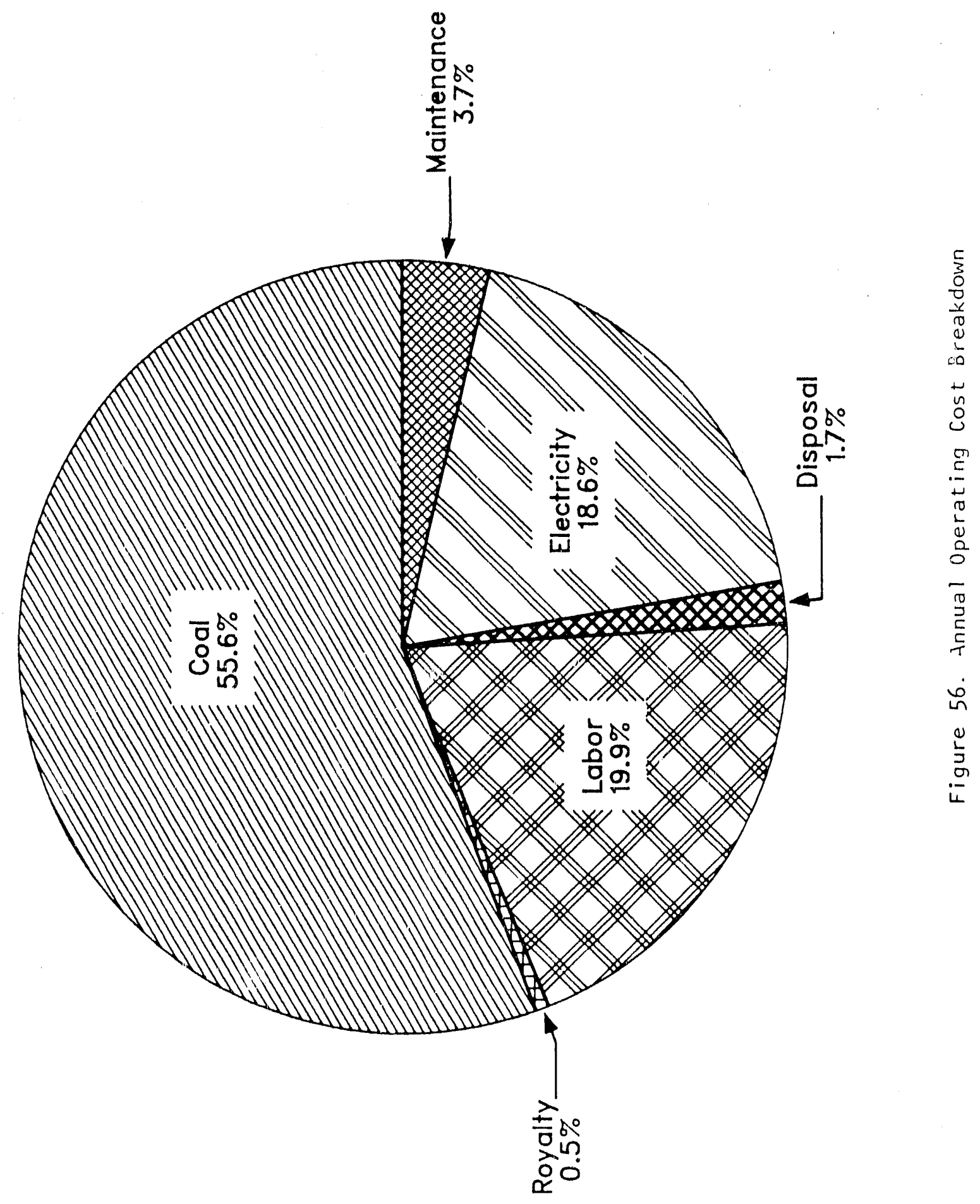


Three largest operating cost items are coal, labor and electricity. The coal cost is the largest operating expense $(\$ 7.56$ per ton of briquettes). Labor costs are another major cost item. The high labor cost may be due to the size of the plant and the lack of operating data. The electricity costs are the third largest operating cost item. 
Economic Analysis

A discounted cash flow economics analysis was performed to determine the required selling price, based on the estimated capital and operating costs. The analysis assumed that 3,000 tons per day of coal feed was used to produce 1,726 tons per day of coal briquettes. The coal briquettes were sold at a calculated selling price to produce the required discounted cash flow return on investment (DCFROI).

The base case economic analysis incorporates the following financial assumptions.

Table 42. Base Case Financial Assumptions

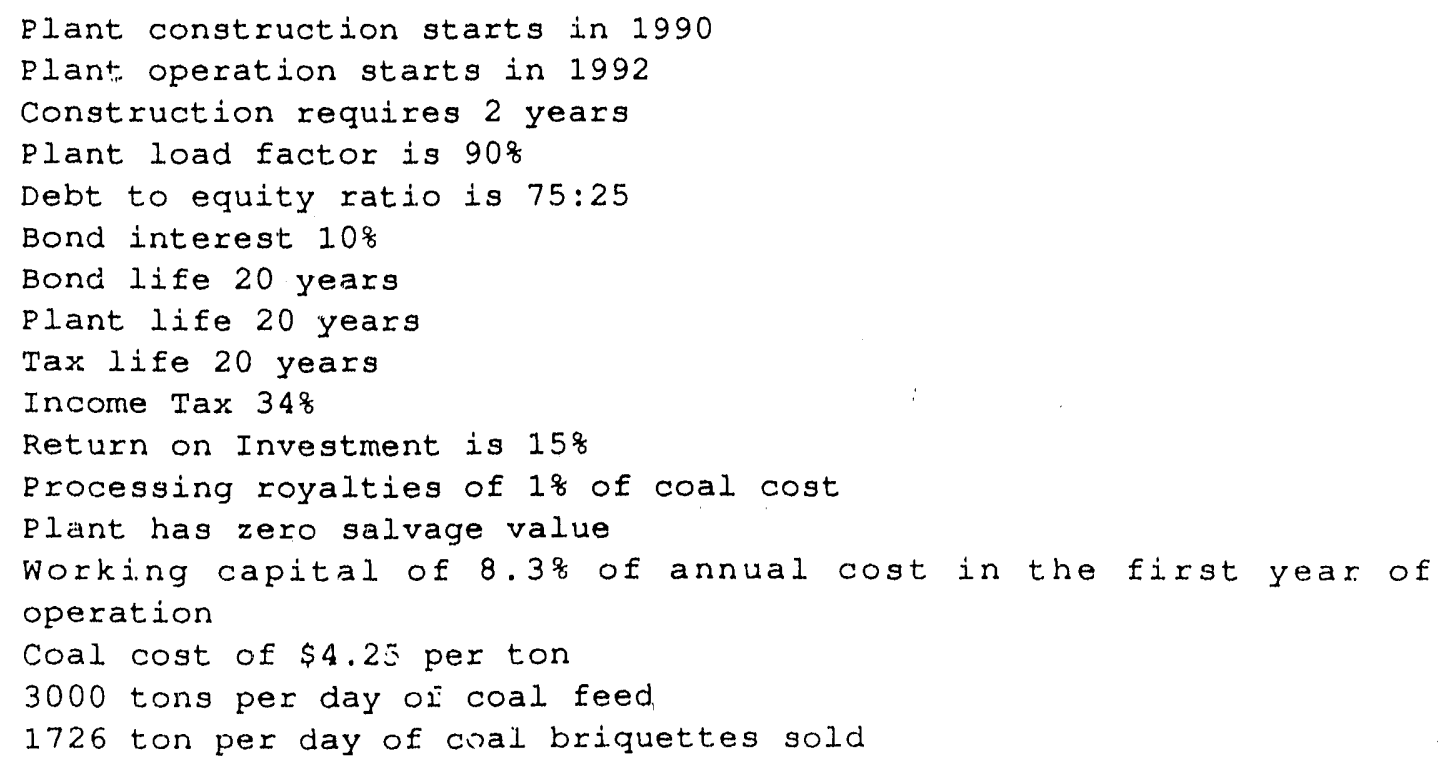

A financial summary of the 2-year construction period is summarized in Table 43. 


\begin{tabular}{|c|c|c|}
\hline & \multicolumn{2}{|c|}{ Construction Year: } \\
\hline & 1 & $\underline{2}$ \\
\hline Amount Borrowed, $\$$ million: & 6.9 & 10.3 \\
\hline Loan Life, years: & 22 & 21 \\
\hline Annual Loan Payment, \$ million: & 0.8 & 1.2 \\
\hline Total Annual Loan Payment, $\$$ million & & 2.0 \\
\hline Equity in Plant, $\$$ million & 2.3 & 3.4 \\
\hline Annual Expenses, \$ million & & 10.7 \\
\hline $\begin{array}{l}\text { Present Worth of Required Money, } \\
\text { smillion }\end{array}$ & 4.4 & 5.4 \\
\hline Present Worth of Recovered Capital, & & \\
\hline$\$$ million & & 0.0 \\
\hline Present Worth Factor: & & 6.3 \\
\hline Required Cash Flow, $\$$ million/year & & 1.6 \\
\hline Net Profit, \$million/year: & & 0.4 \\
\hline Gross Earnings, \$ million/year: & & 11.3 \\
\hline
\end{tabular}

These base case economic assumptions produced the following results:

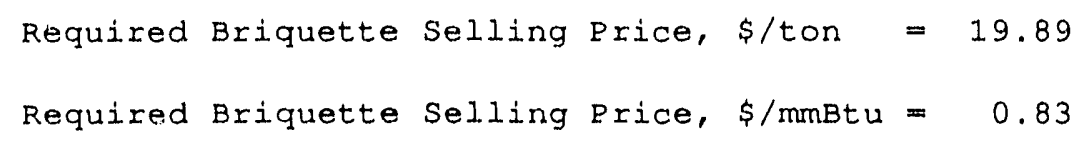


Economic analyses were performed to determine the sensitivity of the required seliling price to changes in estimated capital and operating costs for the base case, and to changes in processing and economics assumptions.

The operation cost for the base case 1 s $\$ 13.57$ per ton of dried coal briquettes. The difference between the operating cost and the required seliling price, $\$ 6.32$ per ton of briquettes, represents the amortized capital cost. The operating cost, excluding coal cost, associated with coal drying and briquetting is only $\$ 6.01$ per ton of briquettes. The relationship of capital and operating cost to the required seling price is graphically illustrated in Figure 57.

The major cost items and their contributions to the required selling price is shown in Table 44 .

Table 4. Briquette Selling Rrice Breakdown

\begin{tabular}{lc}
\hline \multicolumn{1}{c}{ Major Costs } & $\begin{array}{c}\text { Contribution to Required } \\
\text { Seling Rrice, } / \text { ton }\end{array}$ \\
\hline Permit & 0.07 \\
Installed Equipment & 5.84 \\
Engineering & 0.41 \\
Coal & 7.56 \\
Maintenance & 0.50 \\
Electricity & 2.52 \\
Disposal & 0.23 \\
Labor & 2.69 \\
Royalty & 0.07 \\
Total & 1.9 .89 \\
\hline
\end{tabular}




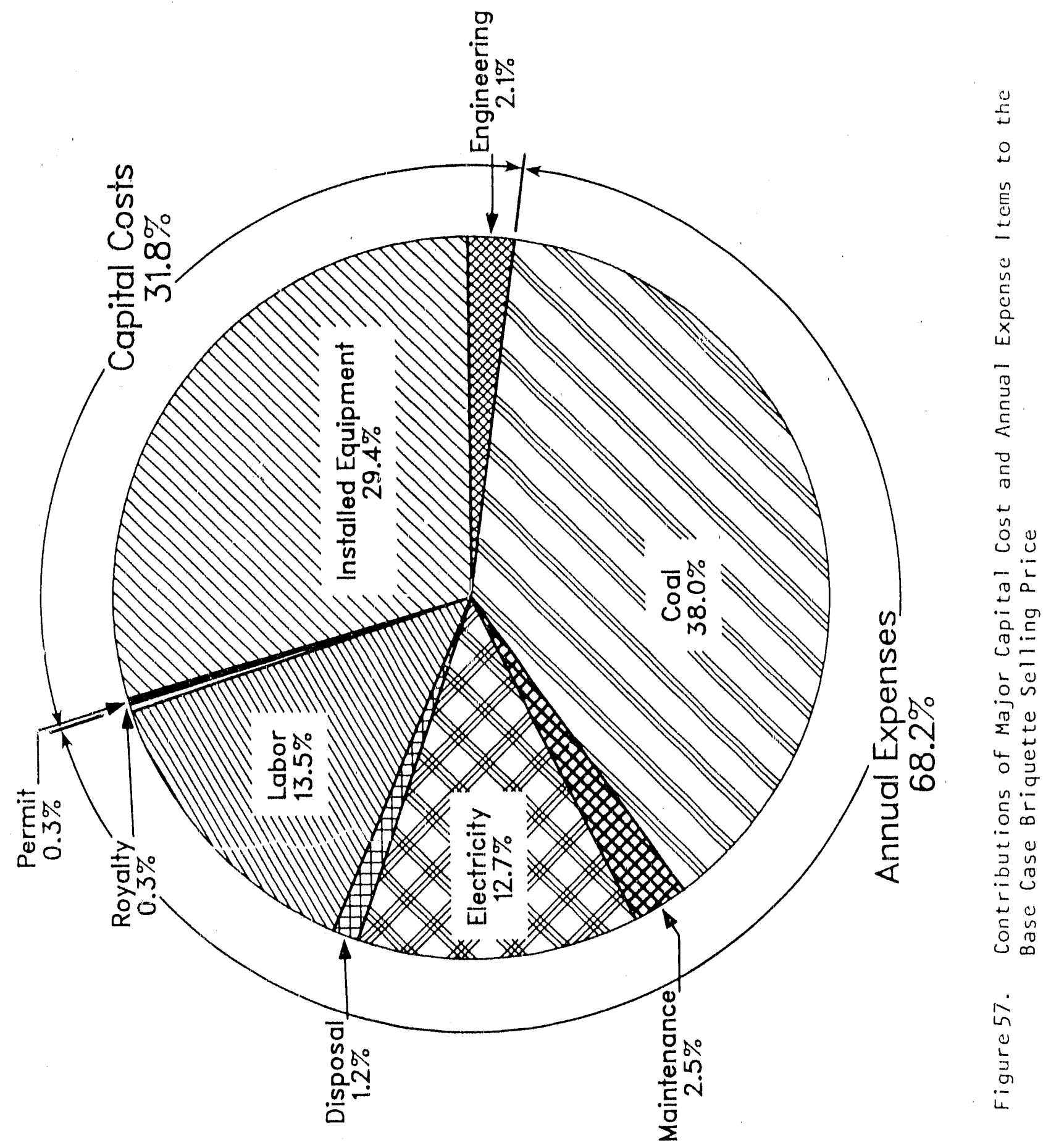


The contribution of these major cost ttems is shown in Figure 55. This indicates the process is sensitive to operating costs, especially coal cost. The major cost items are the coal, installed equipment, labor and electricity.

To evaluate the sensitivity of the base case to economic assumptions, a selected assumption was varied while all other base case conditions were held constant. To determine sensitivity of financing, DCFROI was calculated at four levels $(10,15,20$ and 25$)$ for three levels of financing debt to equity ratios $(85: 15,75: 25$, and $0: 100)$. The required selling price for the these twelve cases is presented in Table 45 and plotted in Figure 58 . 
Table 45. Required Briquette selling price at Various of DCrROI and Debt/Equity (\$/Ton)

\begin{tabular}{llll}
\hline & \multicolumn{3}{c}{ Debt/Equity } \\
\cline { 2 - 4 } DCFROI, \& & $85 / 15$ & $75 / 25$ & $0 / 100$ \\
\hline 10 & & & \\
15 & 18.54 & 18.70 & 19.94 \\
20 & 19.48 & 19.89 & 22.95 \\
25 & 20.51 & 21.19 & 26.30 \\
& 21.62 & 22.59 & 29.89 \\
\hline
\end{tabular}

The required selling price is very sensitive to financing at high values of DCFROI and relatively unsensitive at lower values of DCFROI.

To evaluate the effect of annual operating costs on selling price, the required selling price was determined for DCFROI values of $10,15,20$ and 25 and at \pm 208 of the base case annual operating cost. The results are presented in Table 46 and plotted in Figure 59.

Table 46. Required 3riquette Selling Price in \$/Ton as a Function of DCrROI and Annual Expenses

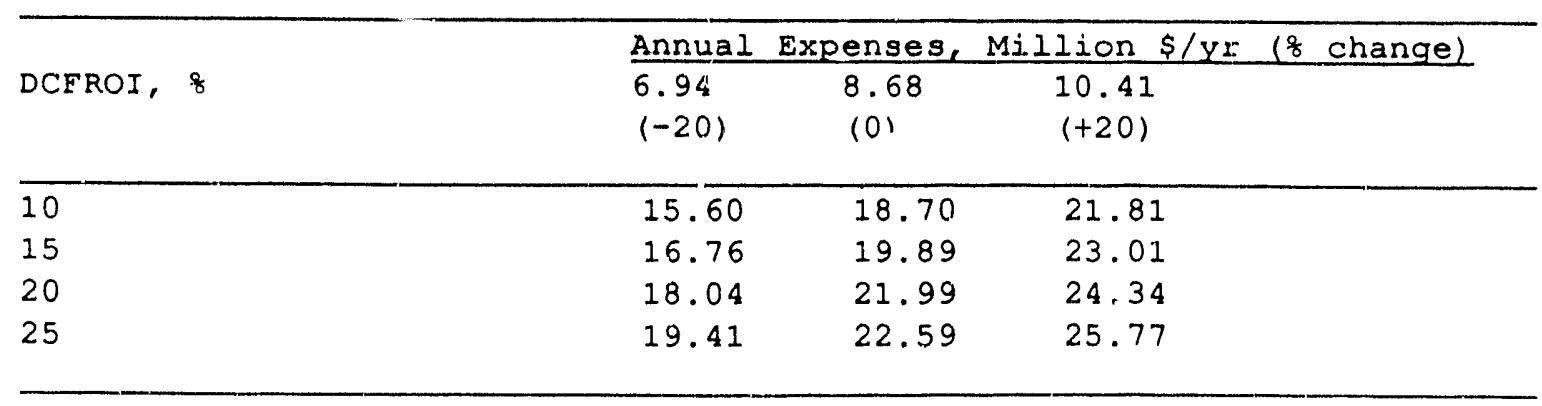




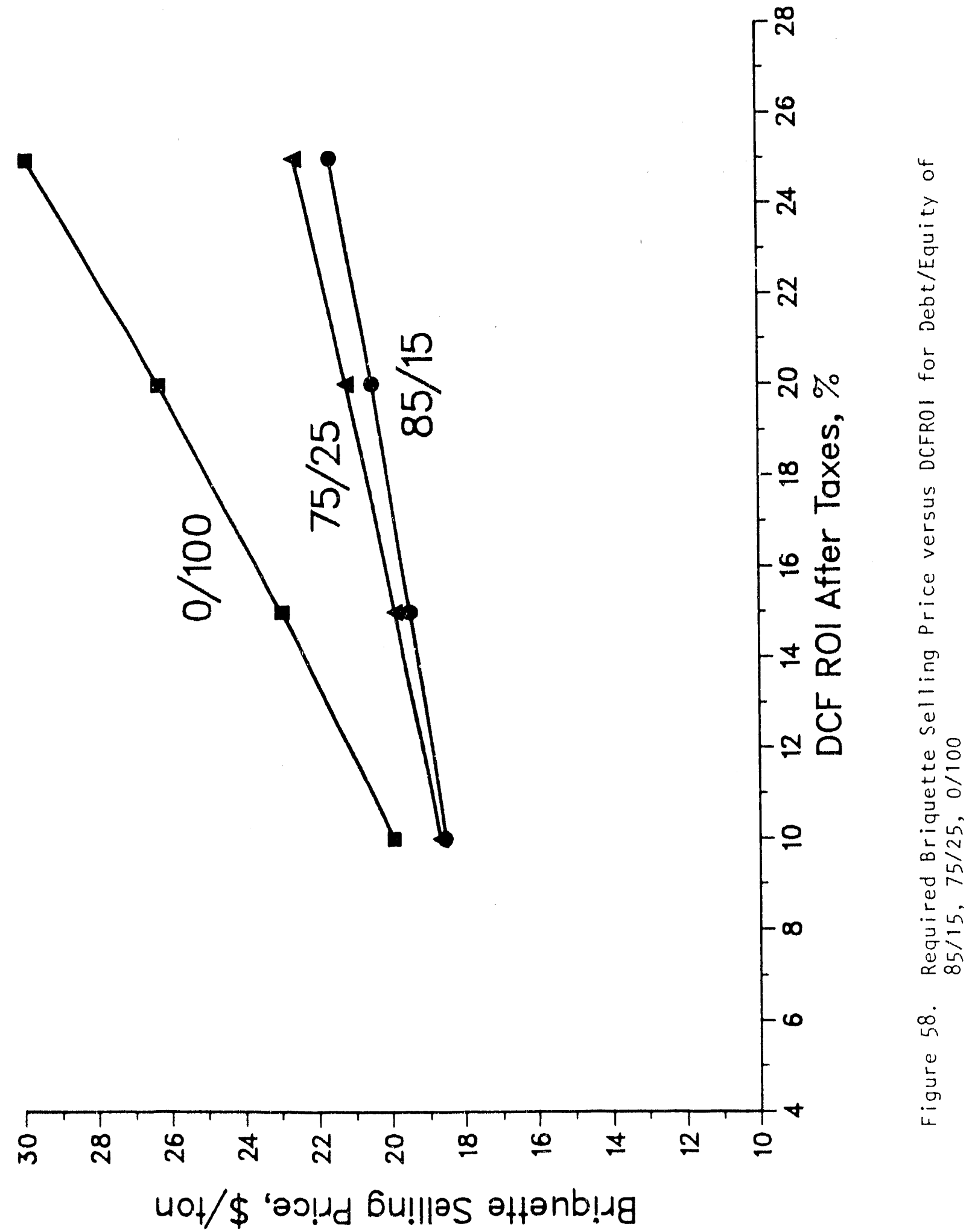




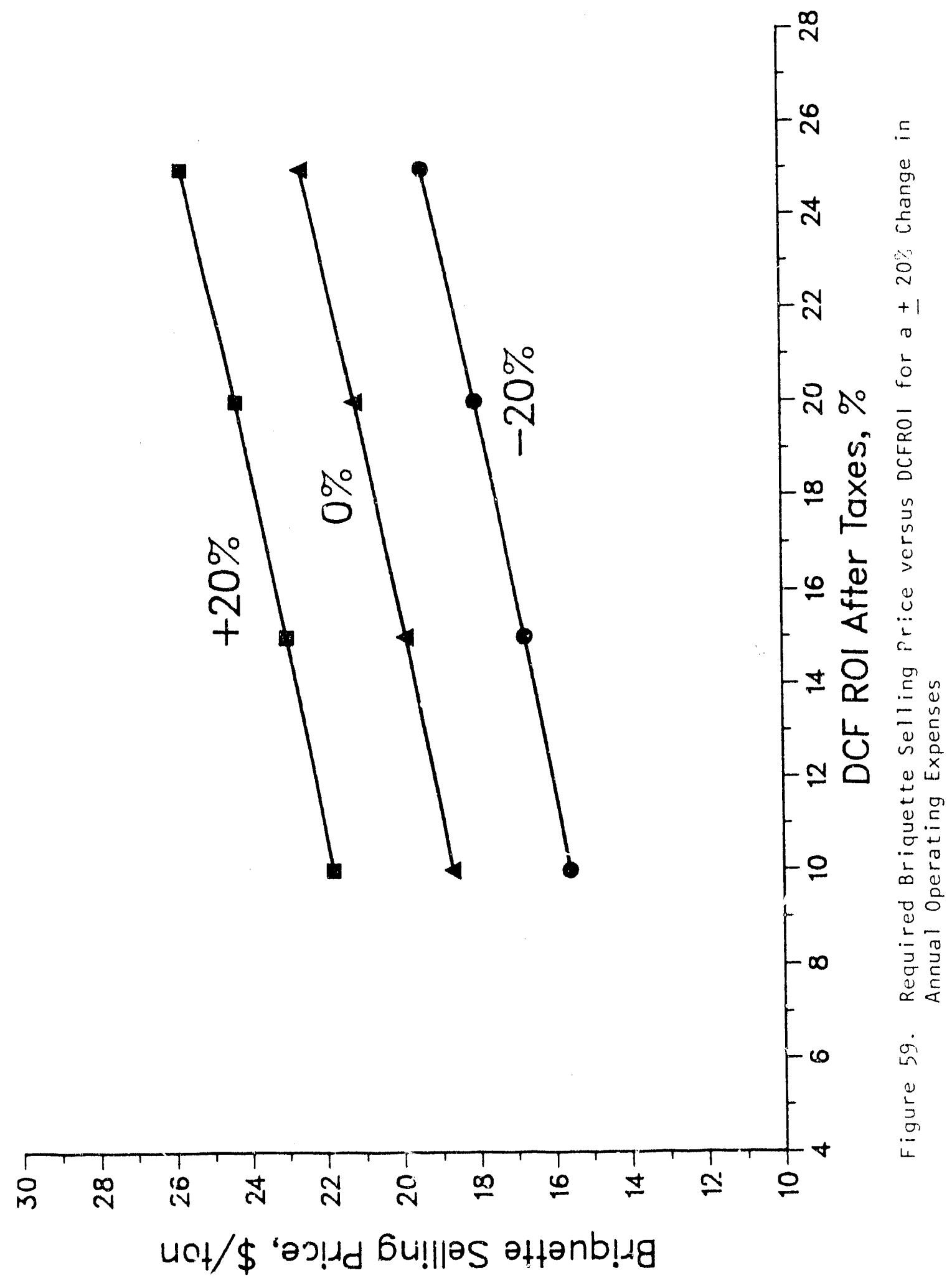


At $10 \%$ DCFROI a change of $\pm 20 \%$ of the annual operating cost, produces a change of $\pm 3.10 /$ ton on the required selling price of the briquettes or $17 \%$ of base case. A change of $\pm 20 \%$ at a DCFROI of $25 \%$, produces a change of $\$ 3.18 /$ ton of the required selling price of the briquettes or 148 of the base case.

To evaluate the effect of capital cost, the required selling price was calculated for $10,15,20$ and $25 \%$ DCFROI at $\pm 20 \%$ of the base case capital costs. This set of assumptions yielded the data summarized in Table 47 and plotted in Figure 60.

Table 47. Required Briquette Selling price in \$/Ton as a runction of DCrROI and Total Capital Cost.

\begin{tabular}{|c|c|c|c|}
\hline \multirow[b]{2}{*}{ DCFROI， के } & \multicolumn{2}{|c|}{ Total Capital Cost } & Million $\$ / y r$ (o change) \\
\hline & $\begin{array}{l}18.927 \\
(-20)\end{array}$ & $\begin{array}{l}23.658 \\
(0)\end{array}$ & $\begin{array}{l}28.390 \\
(+20)\end{array}$ \\
\hline 10 & 17.52 & 18.70 & 19.89 \\
\hline 15 & 18.47 & 19.89 & 21.30 \\
\hline 20 & 19.51 & 21.66 & 22.87 \\
\hline 25 & 20.63 & 22.59 & 24.55 \\
\hline
\end{tabular}




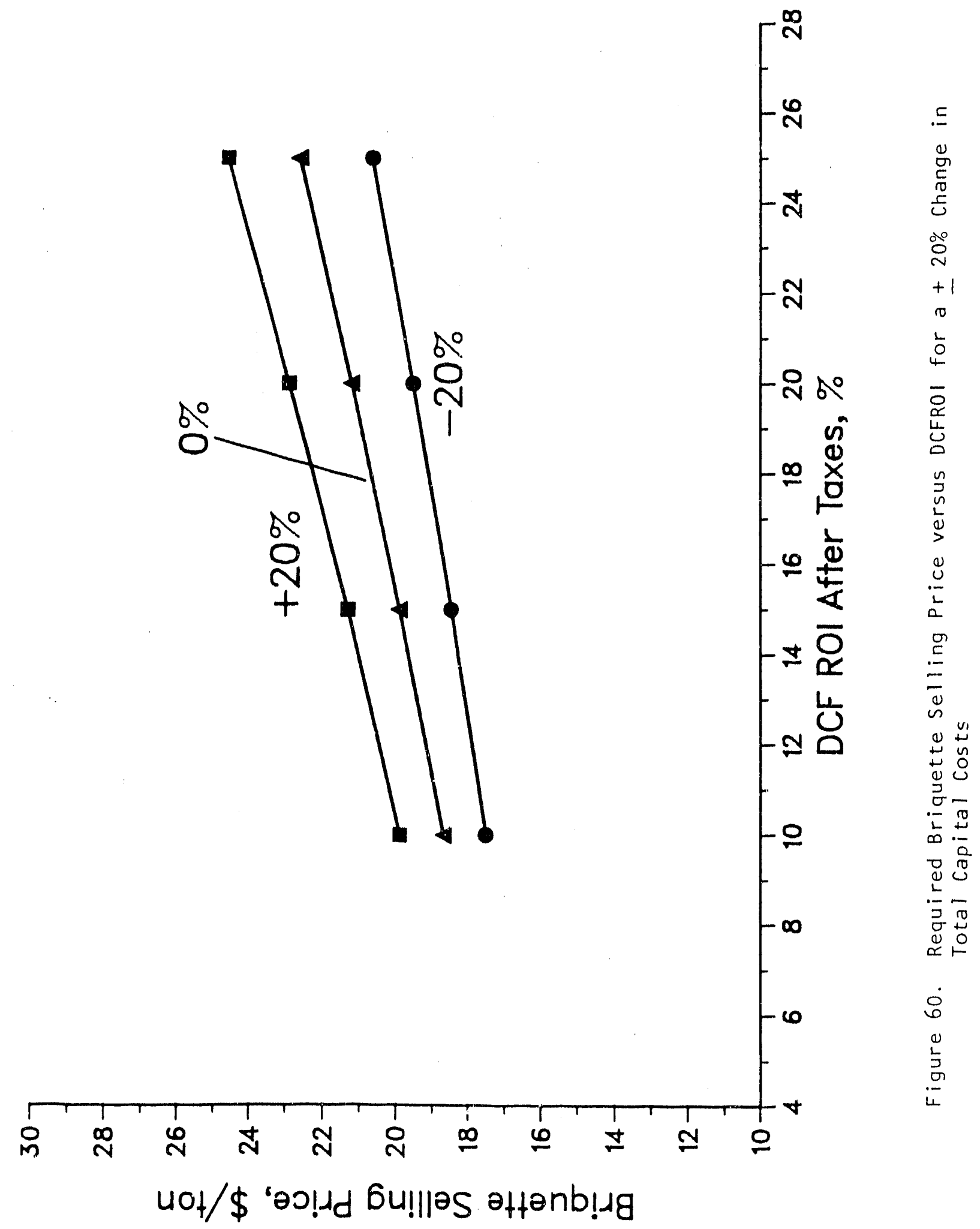


At $10 \%$ DCFROI, a capital cost change of $\pm 20 \%$ produced a change of \pm $\$ 1.18 /$ ton of the required selling price or $6 \%$ of the base case. At $25 \%$ DCFROI, the change was $\$ 1.96 /$ ton or 98 of the base case.

Within the scope of this analysis, the process appears to be sensitive to the following items in decreasing order of significance:

- Financing considerations (Debt/Equity)

- Annual operating cost

- Total capital cost

- Labor cost

- Electricity cost

- Briquetting section capital cost

- Drying section capital cost

These economic relations should be useful in directing future technical development efforts. 


\section{CONCIUSIONS}

The main objective of this research was to develop a thermal process for drying fine coal that (1) reduces explosion potential, (2) uses a fluidized bed with minimum elutriation, (3) produces a stable dry coal by preventing moisture reabsorption and autogenous heating, (4) reduces fugitive dust emissions, and (5) is technically and economically feasible.

The research conducted has demonstrated that:

1) The explosion potential can be minimized by operation of the process at a slight positive pressure and by using carbon dioxide produced from decarboxylation of the coal during drying.

2) Elutriation from the fluidized bed can be controlled to be less than 15 wt for a -28 -mesh coal feed through the use of inclined fluidized-bed with a slope of $6^{\circ}$ to $15^{\circ}$.

3) A dried coal can be produced with less than 1 wt moisture based upon proximate analysis. The dried coal will absorb signjeficantly less moisture than the feed coal or dried coals produced from conventional processes using air and lower drying temperatures. Equilibrium moisture of dried coal briquettes is $7.6 \%$, much lower than the feed coal.

But, the dried coal is more susceptible to spontaneous heating than the feed coal. Currently, it is not possible to determine if the 
increased susceptibility to spontaneous ignition is likely to cause problems in handing and storage of the coal. This is because severe conditions were required to initiate the spontaneous igrition of the dried coal. Originally, the spontaneous heating tests were planned to be performed using a moist oxygen flowrate of $80 \mathrm{ml} / \mathrm{min}$. However, the samples failed to ignite under these conditions. Consequently, the spontaneous heating tests were performed using a moist oxygen flowrate of $160 \mathrm{ml} / \mathrm{min}$.

If spontaneous ignition problems do arise, partial oxidation of the dried coal is an inexpensive method to reduce the susceptibility of the dried coal to spontaneous heating. Further, the conceptual 3,000 ton/day commercial IFB coal drying plant was designed to produce a briquetted dry coal which should not be susceptible to spontaneous ignition. Other processes to reduce the susceptibility of the dried coal to spontaneous heating, such as pelletizing and oil pyrolysis, should also be considered.

4) The fugitive dust emissions from the dried coal are much less than from the feed coal.

5) The IFB coal drying process is proven technically feasible at the $10 \mathrm{lb} / \mathrm{hr}$ bench-scale and no significant operating or maintenance problems occurred during the experimentation at that scale. Preliminary economic projections for 3,000 ton/day commercial operation indicate the process may have commercial potential. 
6) Capital investment for a 3,000 ton/day coal drying plant is estimated at 24 million dollars including contingency and working capital. Approximately $34 \%$ of capital cost is associated with the briquetting operation.

7) The operating cost associated wath drying and briquetting is $\$ 6.01$ per ton of briquettes. For a $\$ 4.25 /$ ton of raw coal cost, the required seling price for dried coal briquettes is $\$ 19.89 /$ ton or $\$ 0,3 / \mathrm{mmBtu}$.

In conclusion, the research conducted thus far was successful in meeting all the project objectives except the stabilization of the dried coal to spontaneous ignition. Based upon the results of this research, continued development of IFB coal drying process is recommended. Research into the scale-up of the frocess should include significant scale-up of the process throughput and operation of the process using a larger feed particle size. In addition, partial oxidation of the dried coal to stabilize it with respect io spontaneous heating should be investigated along with other potential processes for stabilization of the dried coal.

\section{ACKNOWLEDGMENT}

The authors wish to express their sincere appreciation to the U.S. Department of: Energy for funding this work under Contract Number DE-AC2288FC88886. Specific thanks are expressed to Messrs. Albert Deurbrouck, Richard Hucko and Shelby Rogers, of the Pittsburgh Energy Technology Center 
of the U.S. DOE for their interest and support to initiate this project. Personnel at the western Research Institute who contributed significantly to the success of this research are Ronald Beckett, Godwin Biezugbe, Robert Cummings, Jan O'Dell, Dan Olson, Robert Shaw, Allan Sullivan, Robert Tweed, and Steve Roach. In addition, Mr. Steven Denton of Usibelli Coal Mining, Inc. and Mr. Raul Woessner of AMAX Coal Company provided assistance and encouragement for the completion of this work.

\section{DISCLAIMER}

Mention of specific brand names or models of equipment is for information only and does not imply endorsement of any particular brand. 


\section{RETERENCES}

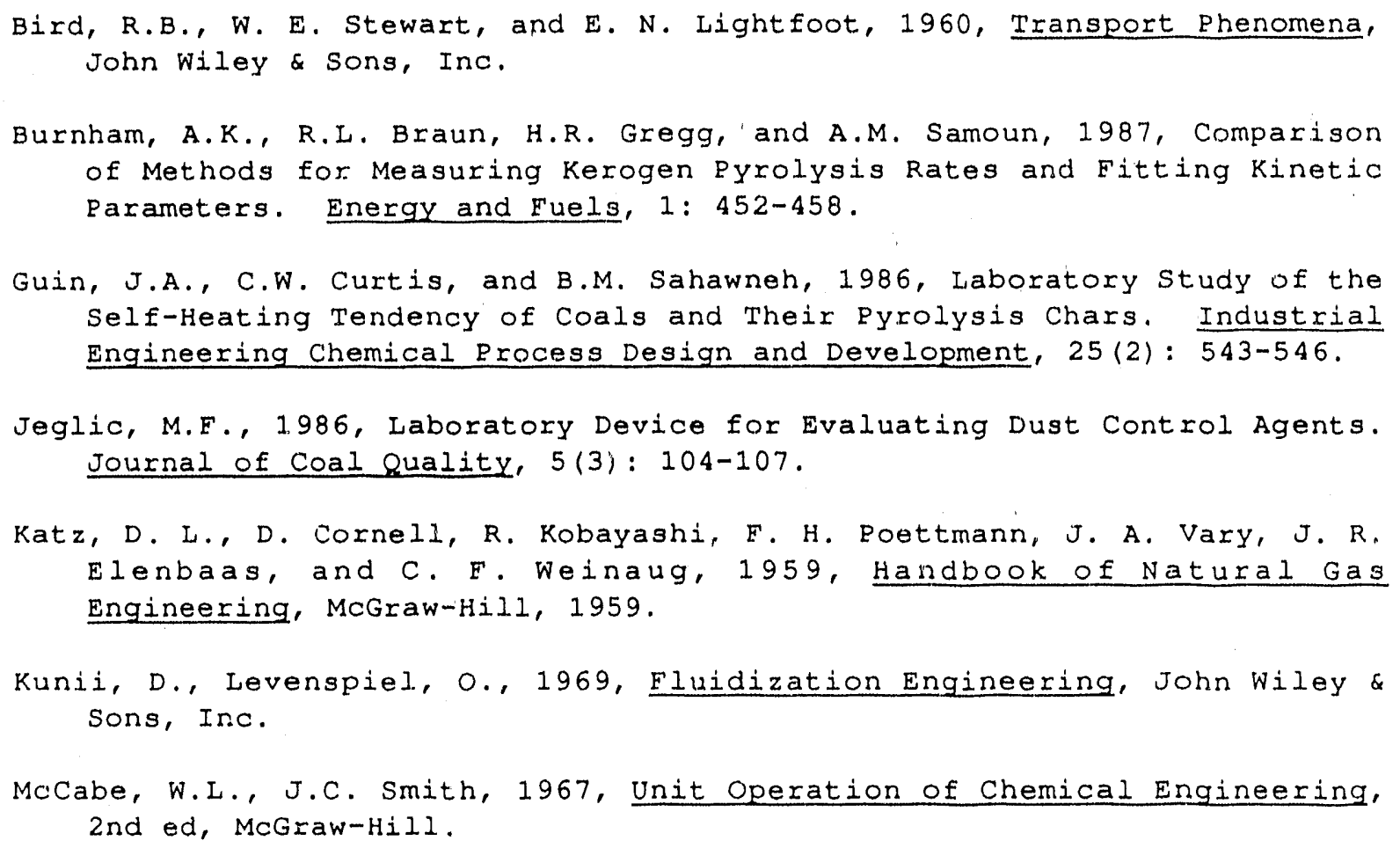


APPENDIX A 
MATERIAL BALANCE FOR COAL DRYING EXPERIMENT: D-31

\begin{tabular}{|c|c|c|c|c|c|c|}
\hline MASS & & $\begin{array}{l}\text { Total } \\
(1 \mathrm{~b})\end{array}$ & $\begin{array}{l}V M \\
(1 \mathrm{~b})\end{array}$ & $\begin{array}{l}F C \\
(1 \mathrm{~b})\end{array}$ & $\begin{array}{l}\text { Ash } \\
(\mathrm{lb})\end{array}$ & $\begin{array}{c}\text { Moisture } \\
\text { (lb) }\end{array}$ \\
\hline IN : & Feed Coal & 131.72 & 41.10 & 46.23 & 6.34 & 38.07 \\
\hline \multirow[t]{2}{*}{ OUT: } & $\begin{array}{l}\text { Product } \\
\text { Volatiles } \\
\text { Ent. Solids } \\
\text { Moisture }\end{array}$ & $\begin{array}{l}48.31 \\
11.61 \\
30.87 \\
38.00\end{array}$ & $\begin{array}{r}16.52 \\
11.61 \\
12.97 \\
0.00\end{array}$ & $\begin{array}{r}28.31 \\
0.00 \\
15.72 \\
0.00\end{array}$ & $\begin{array}{l}3.48 \\
0.00 \\
2.13 \\
0.00\end{array}$ & $\begin{array}{r}0.00 \\
0.00 \\
0.06 \\
38.00\end{array}$ \\
\hline & Total out: & 128.80 & 41.10 & 44.03 & 5.61 & 38.07 \\
\hline CLOSURE & ( $\%$ of Input): & 97.8 & 100.0 & 95.2 & 88.5 & 100.0 \\
\hline
\end{tabular}

\begin{tabular}{|c|c|c|c|c|c|c|}
\hline PROXIMATE & ANALYSES & $\begin{array}{c}\text { Total } \\
(x)\end{array}$ & $\begin{array}{l}V M \\
(\%)\end{array}$ & $\begin{array}{l}F C \\
\left(w_{1}\right)\end{array}$ & $\begin{array}{l}\text { Ash } \\
(x)\end{array}$ & $\begin{array}{c}\text { Moisture } \\
\text { (क) }\end{array}$ \\
\hline IN : & Feed Coal & 100.0 & 31.2 & 35.1 & 4.8 & 28.9 \\
\hline OUT: & $\begin{array}{l}\text { Product } \\
\text { Volatiles } \\
\text { Ent. Solids } \\
\text { Moisture }\end{array}$ & $\begin{array}{l}100.0 \\
100.0 \\
100.0 \\
100.0\end{array}$ & $\begin{array}{r}34.2 \\
100.0 \\
42.0 \\
0.0\end{array}$ & $\begin{array}{r}58.6 \\
0.0 \\
50.9 \\
0.0\end{array}$ & $\begin{array}{l}7.2 \\
0.0 \\
6.9 \\
0.0\end{array}$ & $\begin{array}{r}0.0 \\
0.0 \\
0.2 \\
100.0\end{array}$ \\
\hline
\end{tabular}

EXPERIMENTAL YIELD SUMMARY

\begin{tabular}{|c|c|c|c|c|c|c|}
\hline YIELD $\quad(\%$ & of Input) & $\begin{array}{c}\text { Total } \\
(\%)\end{array}$ & $\begin{array}{l}V M \\
(k)\end{array}$ & $\begin{array}{l}\mathrm{FC} \\
(\mathrm{c})\end{array}$ & $\begin{array}{l}\text { Ash } \\
(\text { क })\end{array}$ & $\begin{array}{c}\text { Moisture } \\
(\text { (क) }\end{array}$ \\
\hline OUT: & $\begin{array}{l}\text { Product } \\
\text { Volatiles } \\
\text { Ent. Solids } \\
\text { Moisture }\end{array}$ & $\begin{array}{r}36.7 \\
8.8 \\
23.4 \\
28.9\end{array}$ & $\begin{array}{r}40.2 \\
28.2 \\
31.6 \\
0.0\end{array}$ & $\begin{array}{r}61.2 \\
0.0 \\
34.0 \\
0.0\end{array}$ & $\begin{array}{r}54.9 \\
0.0 \\
33.0 \\
0.0\end{array}$ & $\begin{array}{r}0.0 \\
0.0 \\
0.2 \\
99.5\end{array}$ \\
\hline & LOSSES $(\%)$ & 2.2 & -0.0 & 4.8 & 11.5 & 0.0 \\
\hline & (15) & 2.92 & 0.00 & 2.21 & 0.73 & 0.00 \\
\hline
\end{tabular}


ATOMIC BALANCE FOR COAL DRYING EXPERIMENT: D-31 DAF EAGLE BUTTE COAL

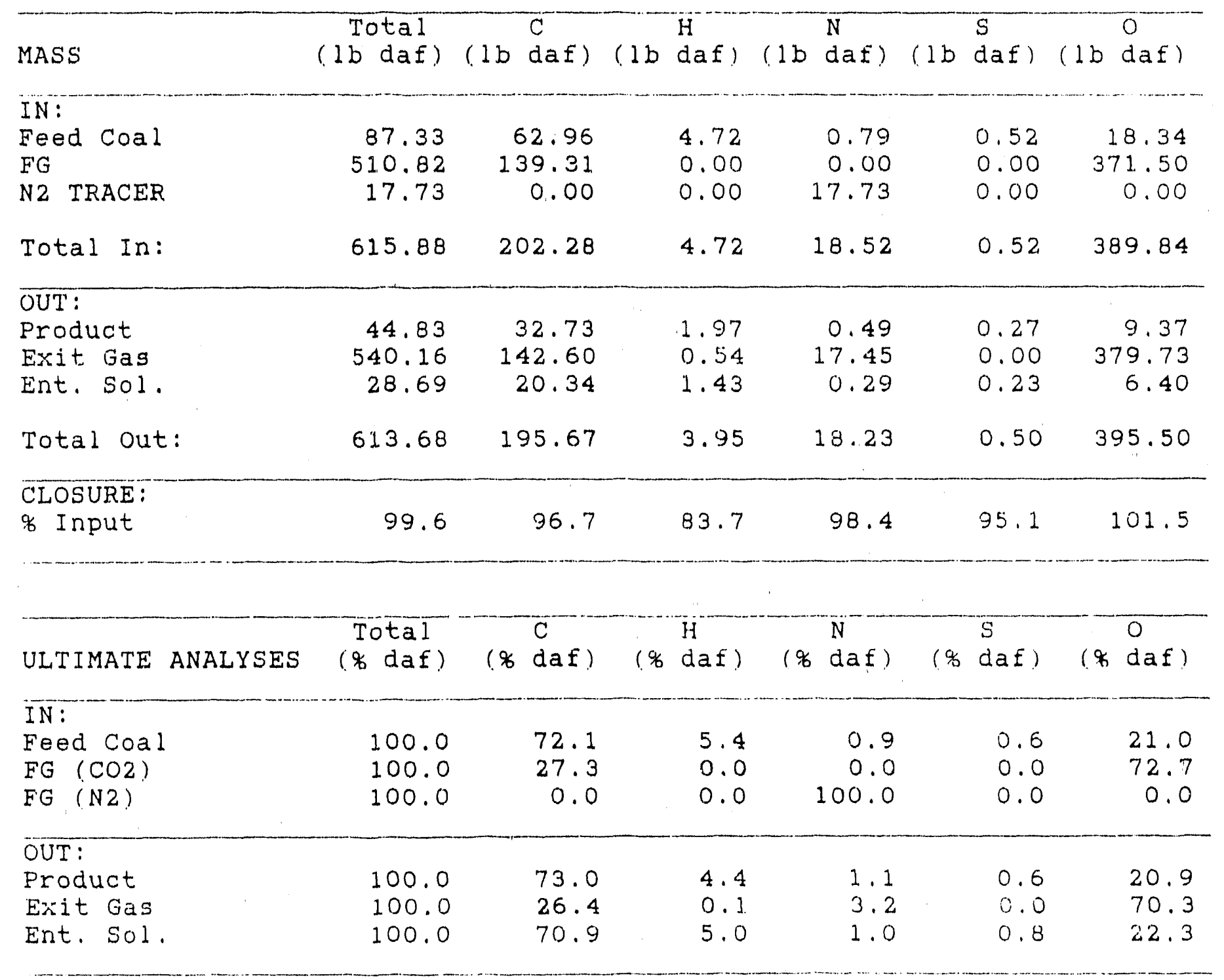


ENERGY BALANCE FOR COAL DRYTNG EXPERIMENT: D-31

EAGLE BUTTE COAL

Exp. Duration, hr:

13.3

\begin{tabular}{lllcc}
\hline ENERGY & Total & Mass & Sensible t Latent & \\
Energy, & Rate, & Heat & Heat Content \\
mbtu/hr & lb/hr & btu/hr & mbtu/hr
\end{tabular}

IN: (T ref. $60 \mathrm{~F})$

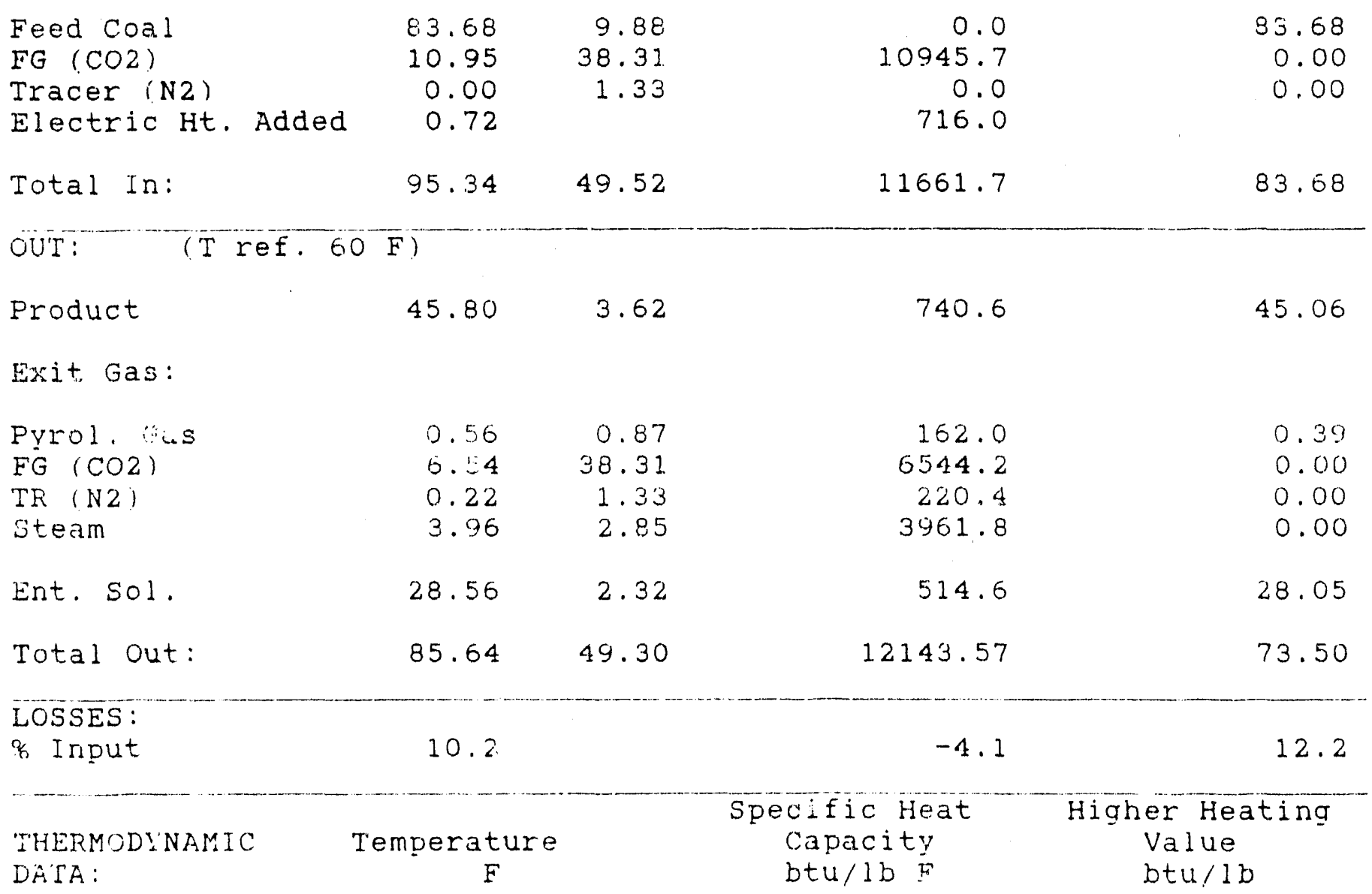

IN : (T ref. $60 \mathrm{~F})$

$\begin{array}{lrrr}\text { Feed COal } & 60 & 0.350 & 8470 \\ \text { FG }(\mathrm{CO} 2) & 1006 & 0.284 & 0 \\ \text { Tracer (N2) } & 60 & 0.249 & 0\end{array}$

OUT: (T ref. bu E)

Product

644

(1. .50

12436

Exit Gas:

Fyrol. Gas

Fo ( $\mathrm{CO} 2)$

Facer ifizi

Steam

695

595

9.2.13

0. 269

453

a. 2.1

(i. 493

Ent. Sol.

595

0. 350

12114 
MATERIAL BALANCE FOR COAL DRYING EXPERIMENT: D-35

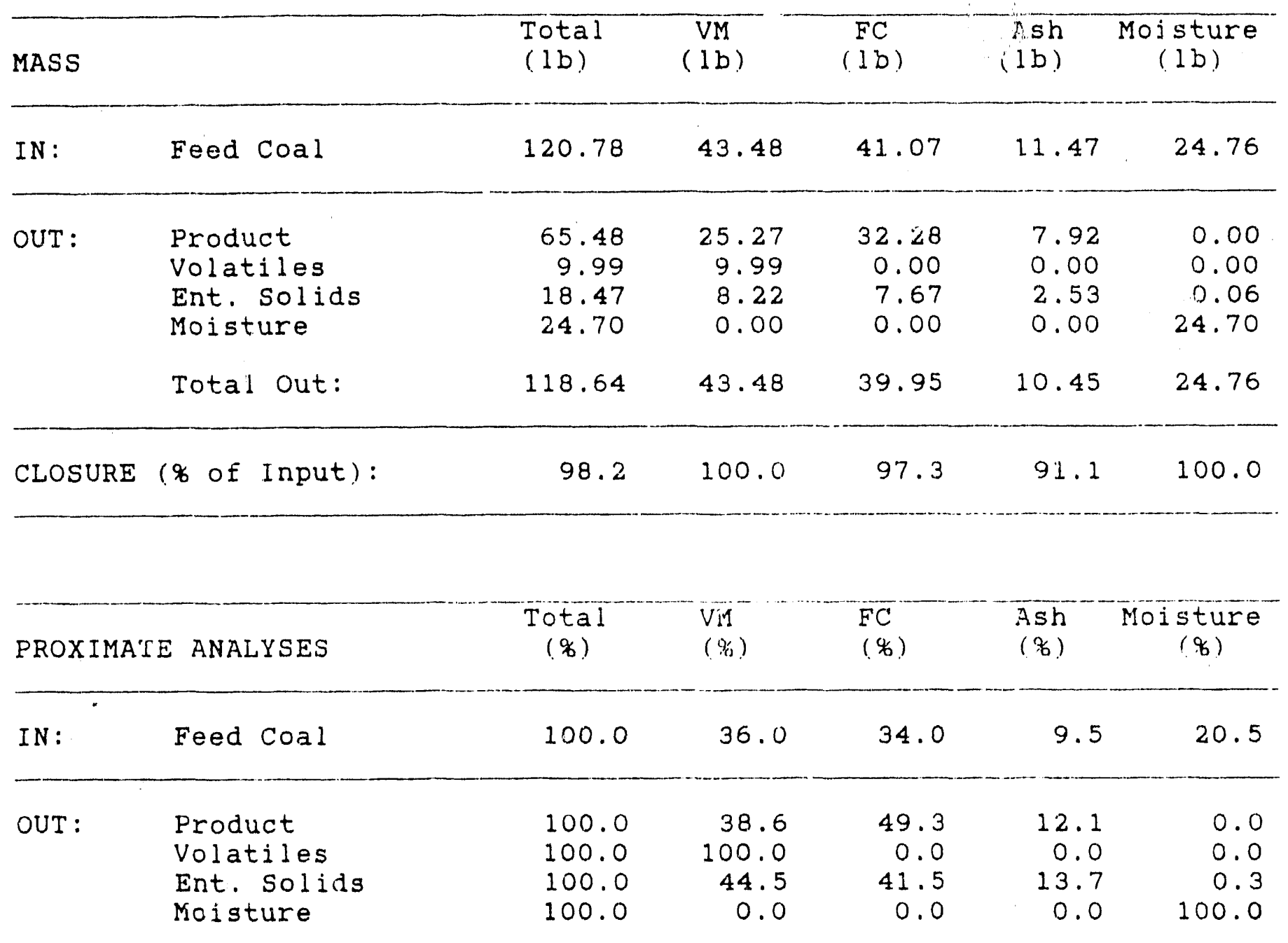

EXPERIMENTAL YIELD SUMMARY

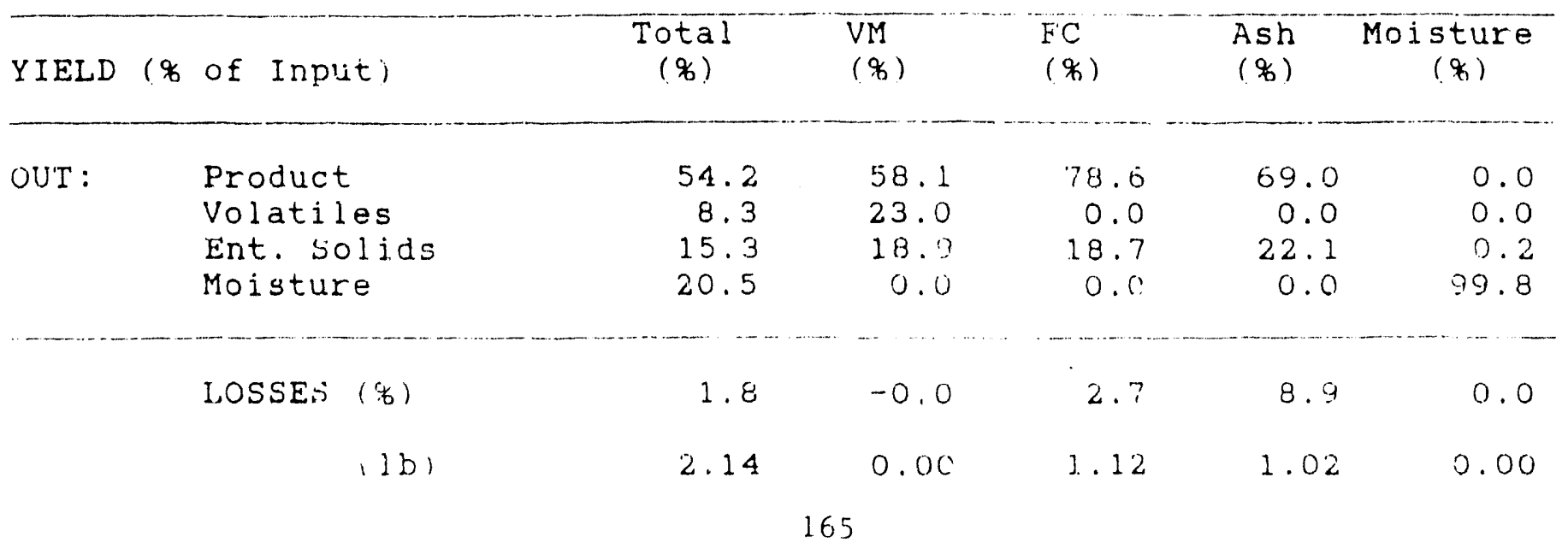


ATOMJC BALANCE FuR COAL DRYING EXPERIMENT: D-35 DAF

USIBELLI COAL

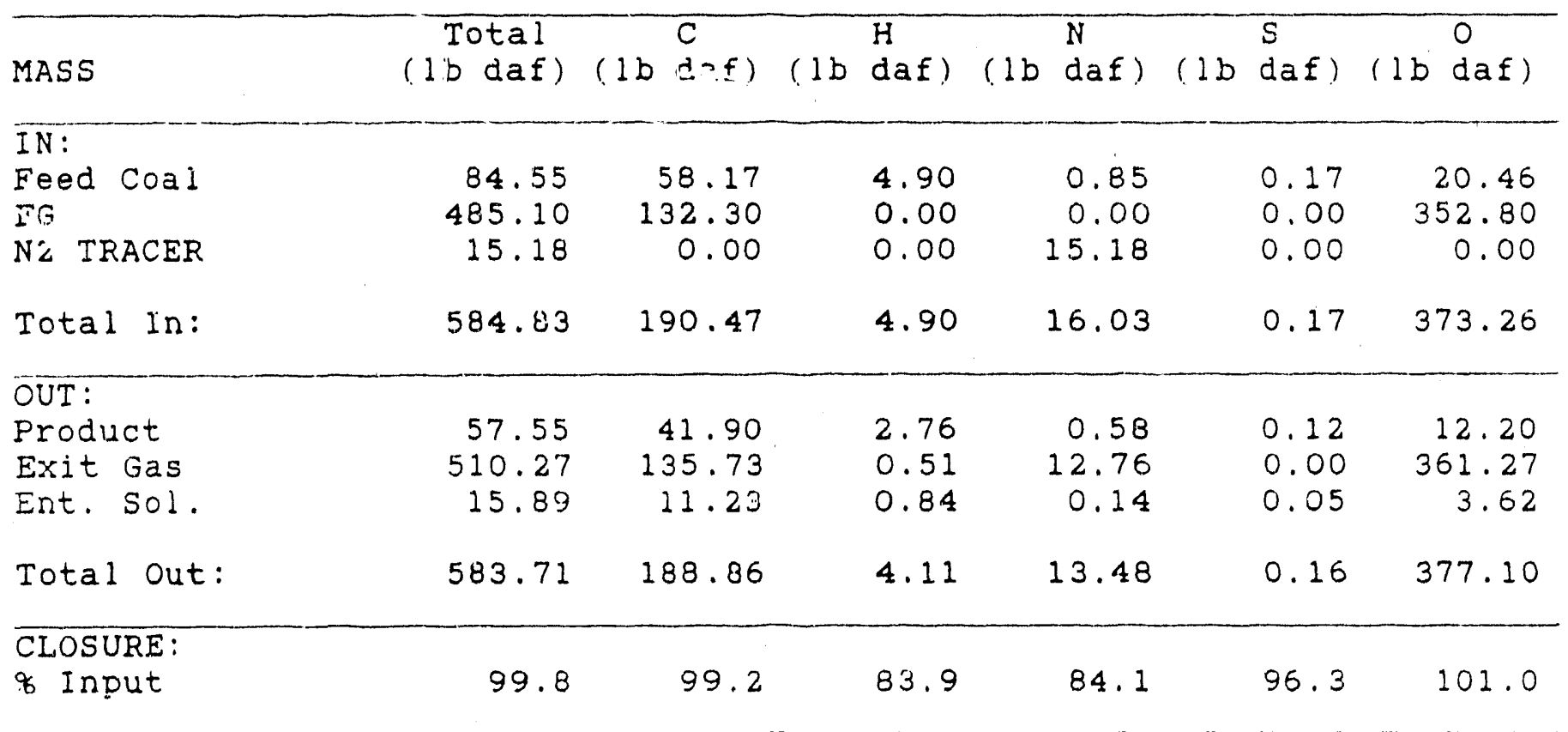

\begin{tabular}{|c|c|c|c|c|c|c|c|c|}
\hline ULTIMATE ANALYSES & $\begin{array}{l}\text { Total } \\
(\% \text { daf })\end{array}$ & (\% daf) & $\left(\begin{array}{l}\mathrm{H} \\
\text { daf })\end{array}\right.$ & $(\%$ daf $)$ & $(\%$ & $\begin{array}{l}\text { S } \\
\text { daf) }\end{array}$ & $1 \%$ & $\begin{array}{l}0 \\
d a f l\end{array}$ \\
\hline $\begin{array}{l}\text { IN: } \\
\text { Feed Coal } \\
\text { EG (CO2) } \\
\text { FG (N2) }\end{array}$ & $\begin{array}{l}100.0 \\
100.0 \\
100.0\end{array}$ & $\begin{array}{r}68.8 \\
27.3 \\
0.0\end{array}$ & $\begin{array}{l}5.8 \\
0.0 \\
0.0\end{array}$ & $\begin{array}{r}1.0 \\
0.0 \\
100.0\end{array}$ & & $\begin{array}{l}0.2 \\
0.0 \\
0.0\end{array}$ & & $\begin{array}{r}24.2 \\
72.7 \\
0.0\end{array}$ \\
\hline $\begin{array}{l}\text { OUT: } \\
\text { Product } \\
\text { Exit Gas } \\
\text { Ent. Sol. }\end{array}$ & $\begin{array}{l}100.0 \\
100.0 \\
100.0\end{array}$ & $\begin{array}{l}72.8 \\
26.6 \\
70.7\end{array}$ & $\begin{array}{l}4.8 \\
0.1 \\
5.3\end{array}$ & $\begin{array}{l}1.0 \\
2.5 \\
0.9\end{array}$ & & $\begin{array}{l}0.2 \\
0.0 \\
0.3\end{array}$ & & $\begin{array}{l}21.2 \\
70.8 \\
22.8\end{array}$ \\
\hline
\end{tabular}


ENERGY BALANCE FOR COAL DRYING EXPERIMENT: D-35

USIBELII COAL

Exp. Duration, hr:

11.4

\begin{tabular}{lllcc}
\hline & Total & Mass & Sensible + latent & Heat Content \\
ENERGY & Energy, & Rate, & Heat & mbtu/hr \\
& mbtu/hr & lb/hr & btu/hr & mbtul
\end{tabular}

IN: $(T$ ref. $60 \bar{F})$

\begin{tabular}{|c|c|c|c|c|}
\hline $\begin{array}{l}\text { Feed Coal } \\
\text { FG (CO2) } \\
\text { Tracer (N2) } \\
\text { Electric Ht. Added }\end{array}$ & $\begin{array}{r}89.61 \\
10.80 \\
0.00 \\
0.57\end{array}$ & $\begin{array}{r}10.58 \\
42.49 \\
1.33\end{array}$ & $\begin{array}{r}0.0 \\
10799.8 \\
0.0 \\
567.0\end{array}$ & $\begin{array}{r}89.61 \\
0.00 \\
0.00\end{array}$ \\
\hline Total In: & 100.97 & 54.40 & 11366.8 & 89.61 \\
\hline OUT: $\quad$ (T ref. 60 & F) & & & \\
\hline Product & 63.85 & 5.74 & 1033.8 & 62.82 \\
\hline Exit Gas: & & & & \\
\hline $\begin{array}{l}\text { Pyrol. Gas } \\
\text { FG (CO2) } \\
\text { TR (N2) } \\
\text { Steam }\end{array}$ & $\begin{array}{l}0.39 \\
6.06 \\
0.19 \\
2.91\end{array}$ & $\begin{array}{r}0.88 \\
42.49 \\
1.33 \\
2.16\end{array}$ & $\begin{array}{r}132.1 \\
6063.8 \\
187.6 \\
2912.8\end{array}$ & $\begin{array}{l}0.26 \\
0.00 \\
0.00 \\
0.00\end{array}$ \\
\hline Ent. Sol. & 17.42 & 1.62 & 312.0 & 17.11 \\
\hline Total out: & 90.83 & 54.21 & 10642.01 & 80.19 \\
\hline $\begin{array}{l}\text { LOSSES: } \\
\% \text { Input }\end{array}$ & 10.0 & & 6.4 & 10.5 \\
\hline
\end{tabular}

\begin{tabular}{lccc}
\hline THERMODYNAMIC & Temperature & Specific Heat & Higher Heating \\
DATA: & Capacity & btu/lb F & Value \\
& & btu/lb
\end{tabular}

IN: $\quad(T$ ref. $60 \mathrm{~F})$

\begin{tabular}{|c|c|c|c|}
\hline $\begin{array}{l}\text { Feed } \mathrm{COa}] \\
\text { FG (CO2) } \\
\text { Tracer (N2) }\end{array}$ & $\begin{array}{r}60 \\
971 \\
60\end{array}$ & $\begin{array}{l}0.350 \\
0.279 \\
0.249\end{array}$ & $\begin{array}{r}8470 \\
0 \\
0\end{array}$ \\
\hline \multicolumn{4}{|c|}{ OUT: $\quad(\mathrm{T}$ ref. $60 \mathrm{~F})$} \\
\hline Product & 575 & 0.350 & 10953 \\
\hline \multicolumn{4}{|l|}{ Exit Gas: } \\
\hline Pyrol. vas & 611 & 0.274 & 300 \\
\hline$E G \quad(\mathrm{CO} 2)$ & 611 & 0.259 & 0 \\
\hline Tacer $(N i)$ & 611 & 0.250 & 0 \\
\hline Steam & 611 & 0.487 & 0 \\
\hline Ent. 301 . & 611 & 0.350 & 10576 \\
\hline
\end{tabular}


MATERIAL BALANCE FOR COAL DRYING EXPERIMENT: D-36

\begin{tabular}{|c|c|c|c|c|c|c|}
\hline MASS & & $\begin{array}{l}\text { Total } \\
\text { (Ib) }\end{array}$ & $\begin{array}{l}V M \\
(1 \mathrm{~b})\end{array}$ & $\begin{array}{l}\mathrm{FC} \\
(\mathrm{lb})\end{array}$ & $\begin{array}{l}\text { Ash } \\
(1 \mathrm{~b})\end{array}$ & $\begin{array}{c}\text { Moisture } \\
\text { (1b) }\end{array}$ \\
\hline IN : & Feed Coal & 131.72 & 49.53 & 44.92 & 15.15 & 22.13 \\
\hline \multirow[t]{2}{*}{ OUT: } & $\begin{array}{l}\text { Product } \\
\text { Volatiles } \\
\text { Ent. Solids } \\
\text { Moisture }\end{array}$ & $\begin{array}{l}73.65 \\
18.26 \\
15.53 \\
21.86\end{array}$ & $\begin{array}{r}24.75 \\
18.26 \\
6.52 \\
0.00\end{array}$ & $\begin{array}{r}36.82 \\
0.00 \\
6.14 \\
0.00\end{array}$ & $\begin{array}{r}11.86 \\
0.00 \\
2.83 \\
0.00\end{array}$ & $\begin{array}{r}0.22 \\
0.00 \\
0.05 \\
21.86\end{array}$ \\
\hline & Total out: & 129.30 & 49.53 & 42.96 & 14.68 & 22.13 \\
\hline CLOSURE & ( $\%$ of Input $):$ & 98.2 & 100.0 & 95.6 & 96.9 & 100.0 \\
\hline PROXIMATI & E ANALYSES & $\begin{array}{c}\text { Total } \\
(\%)\end{array}$ & $\begin{array}{l}V_{i i} \\
(\%)\end{array}$ & $\begin{array}{l}F C \\
(\%)\end{array}$ & $\begin{array}{l}\text { Ash } \\
(\text { ( ) }\end{array}$ & $\begin{array}{c}\text { Moisture } \\
(\%)\end{array}$ \\
\hline IN : & Feed Coal & 100.0 & 37.6 & 34.1 & 11.5 & 16.8 \\
\hline OUT: & $\begin{array}{l}\text { Product } \\
\text { Volatiles } \\
\text { Ent. Solids } \\
\text { Moisture }\end{array}$ & $\begin{array}{l}100.0 \\
100.0 \\
100.0 \\
100.0\end{array}$ & $\begin{array}{r}33.6 \\
100.0 \\
42.0 \\
0.0\end{array}$ & $\begin{array}{r}50.0 \\
0.0 \\
39.5 \\
0.0\end{array}$ & $\begin{array}{r}16.1 \\
0.0 \\
18.2 \\
0.0\end{array}$ & $\begin{array}{r}0.3 \\
0.0 \\
0.3 \\
1.00 .0\end{array}$ \\
\hline
\end{tabular}

EXPERIMEN'AL YIELD SUMMARY

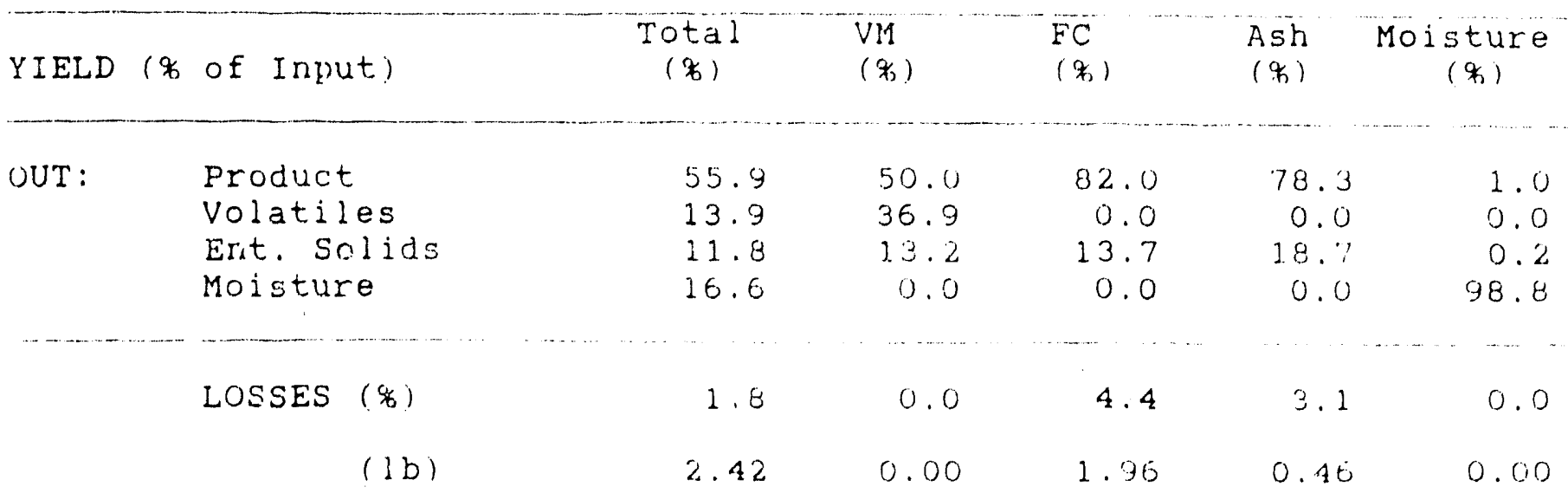


ATOMIC BALANCE FOR COAL DRYING EXPERIMENT: D-36 DAF USIBELLI COAL

\begin{tabular}{|c|c|c|c|c|c|c|c|c|}
\hline MASS & $\begin{array}{l}\text { Total } \\
(13 \text { raf }\end{array}$ & $\left(\right.$ (lb $\left.\begin{array}{l}\mathrm{C} \\
\text { daf }\end{array}\right)$ & $(1 \mathrm{~b}$ & $\begin{array}{l}\mathrm{H} \\
\mathrm{daf})\end{array}$ & $(1 \mathrm{~b}$ daf $)$ & $(1 \mathrm{~b}$ & $\begin{array}{l}S \\
\text { daf) }\end{array}$ & (1b daf) \\
\hline $\begin{array}{l}\text { IN: } \\
\text { Feed Coal } \\
\text { FG } \\
\text { N2 TRACER }\end{array}$ & $\begin{array}{r}94.45 \\
345.96 \\
16.51\end{array}$ & $\begin{array}{r}64.98 \\
94.35 \\
0.00\end{array}$ & & $\begin{array}{l}5.44 \\
0.00 \\
0.00\end{array}$ & $\begin{array}{r}0.94 \\
0.00 \\
16.51\end{array}$ & & $\begin{array}{l}0.23 \\
0.00 \\
0.00\end{array}$ & $\begin{array}{r}22.86 \\
251.61 \\
0.00\end{array}$ \\
\hline Total In: & 456.92 & 159.34 & & 5.44 & 17.46 & & 0.23 & 274.47 \\
\hline $\begin{array}{l}\text { OUT: } \\
\text { Product } \\
\text { Exit Gas } \\
\text { Ent. Sol. }\end{array}$ & $\begin{array}{r}61.57 \\
380.73 \\
12.66\end{array}$ & $\begin{array}{r}45.99 \\
99.37 \\
9.12\end{array}$ & & $\begin{array}{l}2.77 \\
0.38 \\
0.66\end{array}$ & $\begin{array}{r}0.62 \\
17.13 \\
0.13\end{array}$ & & $\begin{array}{l}0.18 \\
0.00 \\
0.04\end{array}$ & $\begin{array}{r}12.01 \\
263.85 \\
2.72\end{array}$ \\
\hline Total out: & 454.96 & 154.48 & & 3.81 & 17.88 & & 0.22 & 278.58 \\
\hline $\begin{array}{l}\text { CLOSURE: } \\
\text { \% Input }\end{array}$ & 99.6 & 97.0 & & 70.0 & 102.4 & & 98.2 & 101.5 \\
\hline ULTIMATE ANALYSES & $\begin{array}{l}\text { Total } \\
(\% \text { daf })\end{array}$ & $(\%$ daf $)$ & $(\%$ & $\begin{array}{l}\mathrm{H} \\
\mathrm{daf} \text { ) }\end{array}$ & $(\%$ daf $)$ & (\% & daf? & $(\%$ daf $)$ \\
\hline $\begin{array}{l}\text { IN: } \\
\text { Feed Ccal } \\
\text { FG }(\mathrm{CO} 2) \\
F G(\mathrm{~N} 2)\end{array}$ & $\begin{array}{l}100.0 \\
100.0 \\
100.0\end{array}$ & $\begin{array}{r}68.8 \\
27.3 \\
0.0\end{array}$ & & $\begin{array}{l}5.8 \\
0.0 \\
0.0\end{array}$ & $\begin{array}{r}1.0 \\
0.0 \\
100.0\end{array}$ & & $\begin{array}{l}0.2 \\
0.0 \\
0.0\end{array}$ & $\begin{array}{r}24.2 \\
72.7 \\
0.0\end{array}$ \\
\hline $\begin{array}{l}\text { OUT: } \\
\text { Prodict } \\
\text { Exit Gas } \\
\text { Ent. Sol. }\end{array}$ & $\begin{array}{l}100.0 \\
100.0 \\
100.0\end{array}$ & $\begin{array}{l}74.7 \\
26.1 \\
72.0\end{array}$ & & $\begin{array}{l}4.5 \\
0.1 \\
5.2\end{array}$ & $\begin{array}{l}1.0 \\
4.5 \\
1.0\end{array}$ & & $\begin{array}{l}0.3 \\
0.0 \\
0.3\end{array}$ & $\begin{array}{l}19.5 \\
69.3 \\
21.5\end{array}$ \\
\hline
\end{tabular}


ENERGY BALANCE FCR COAL DRYING EXPERIMENT: D-36

USIBELLI COAL

Exp. Duration, hr:

12.4

\begin{tabular}{lllcc}
\hline \multirow{2}{*}{ ENERGY } & Total & Mass & Sensible + Latent & \\
Energy, & Rate, & Heat & Heat Content \\
mbtu/hr & lb/hr & btu/hr & mbtu/hr
\end{tabular}

IN: $(\mathrm{T}$ ref. $60 \mathrm{~F})$

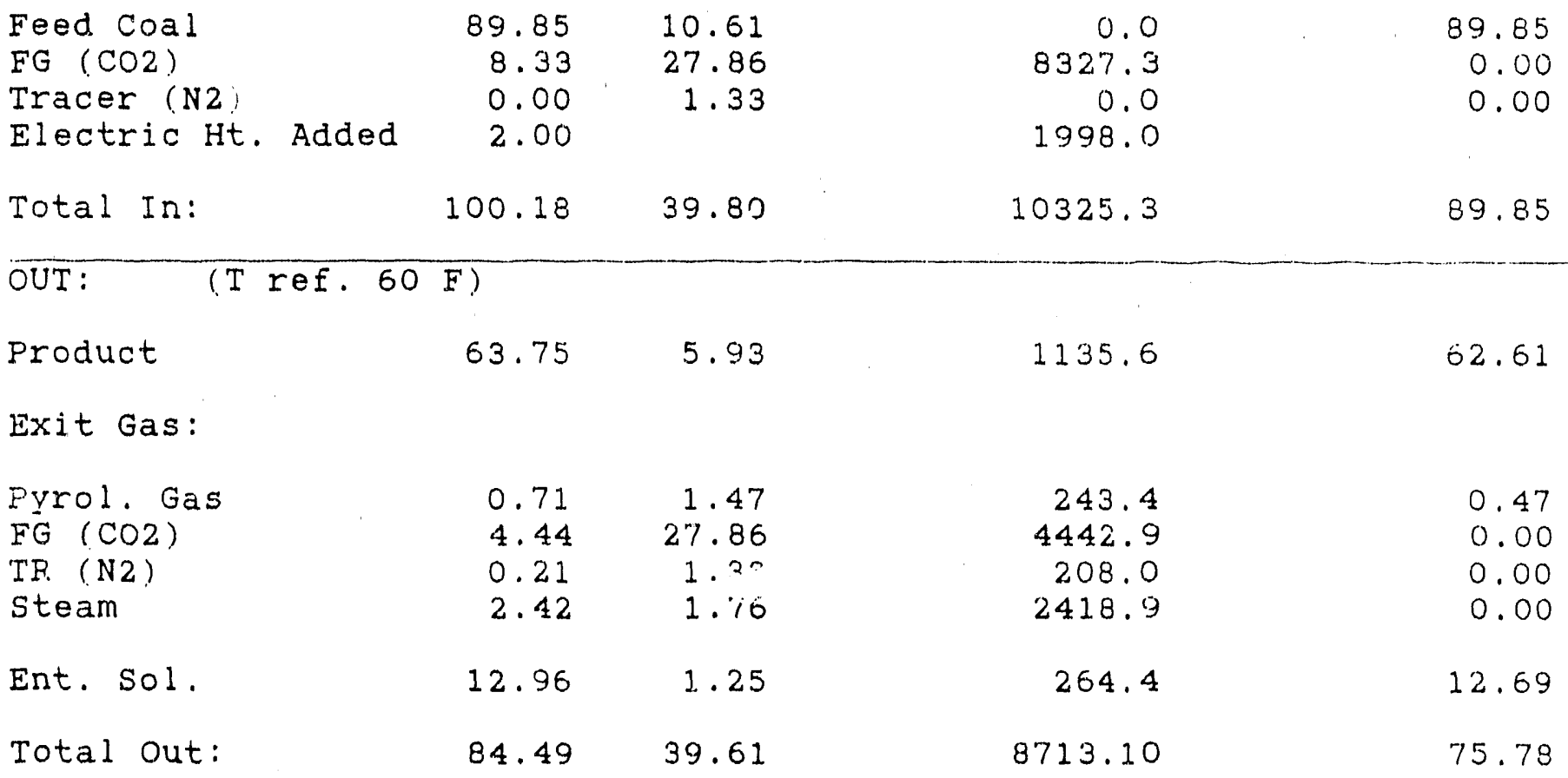

LOSSES:

\% Input

15.7

15.6

15.7

\begin{tabular}{lccc}
\hline & Specific Heat & Higher Heating \\
THERMODYNAMIC & Temperature & Capacity & Value \\
DATA: & F & btu/lb F & btu/lb
\end{tabular}

INI $(\mathrm{T}$ ref. $60 \mathrm{~F})$

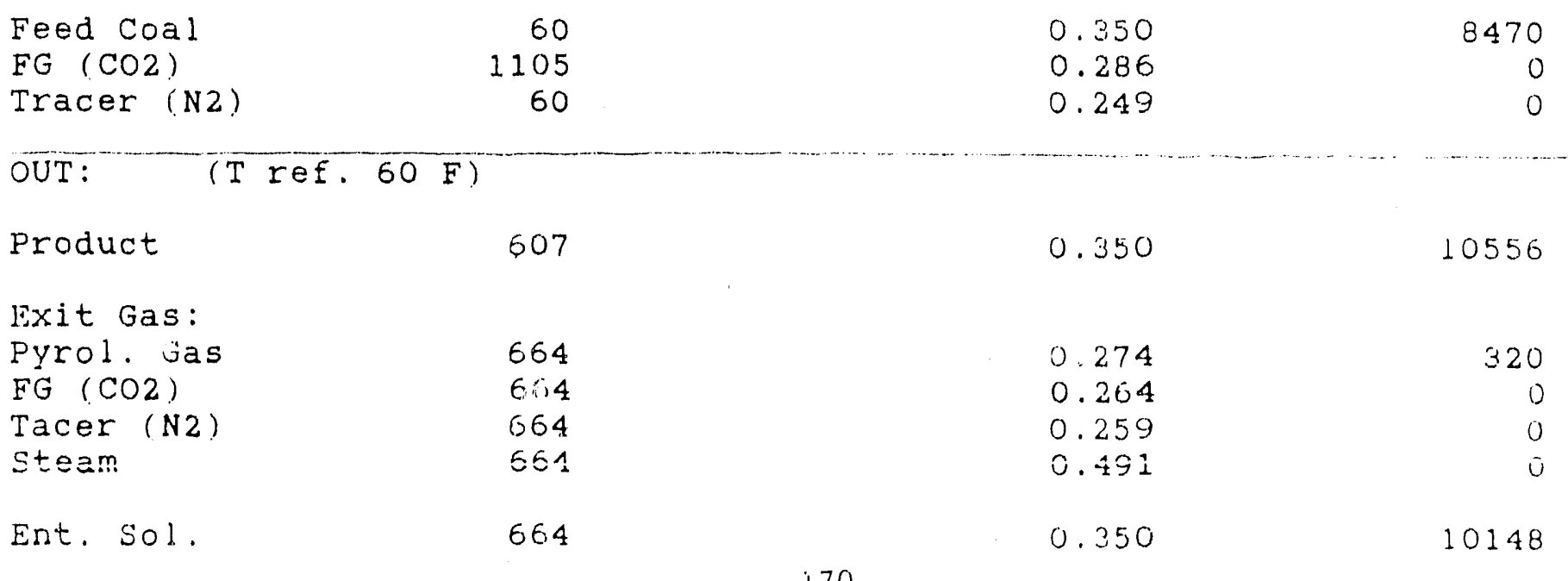


MATERIAL BALANCE FOR COAL DRYING EXPERIMENT: D-37

\begin{tabular}{|c|c|c|c|c|c|c|}
\hline MASS & & $\begin{array}{l}\text { Total } \\
\text { (1b) }\end{array}$ & $\begin{array}{l}\mathrm{VM} \\
(1 \mathrm{~b})\end{array}$ & $\begin{array}{l}\mathrm{FC} \\
(1 \mathrm{~b})\end{array}$ & $\begin{array}{l}\text { Ash } \\
(1 \mathrm{~b})\end{array}$ & $\begin{array}{c}\text { Moisture } \\
\text { (1b) }\end{array}$ \\
\hline IN : & Feed Coal & 126.65 & 41.29 & 45.85 & 6.21 & 33.31 \\
\hline \multirow[t]{2}{*}{ OUT: } & $\begin{array}{l}\text { Product } \\
\text { Volatiles } \\
\text { Ent. Solids } \\
\text { Moisture }\end{array}$ & $\begin{array}{l}60.69 \\
12.74 \\
17.02 \\
33.09\end{array}$ & $\begin{array}{r}21.18 \\
12.74 \\
7.37 \\
0.00\end{array}$ & $\begin{array}{r}34.83 \\
0.00 \\
8.34 \\
0.00\end{array}$ & $\begin{array}{l}4.55 \\
0.00 \\
1.21 \\
0.00\end{array}$ & $\begin{array}{r}0.12 \\
0.00 \\
0.10 \\
33.09\end{array}$ \\
\hline & Total Out: & 123.53 & 41.29 & 43.17 & 5.76 & 33.31 \\
\hline CLOSURE & ( $\%$ of Input): & 97.5 & 100.0 & 94.2 & 92.8 & 100.0 \\
\hline
\end{tabular}

\begin{tabular}{|c|c|c|c|c|c|c|}
\hline PROXIMATE & E ANALYSES & $\begin{array}{c}\text { Total } \\
\text { (\%) }\end{array}$ & $\begin{array}{l}\text { VM } \\
(\%)\end{array}$ & $\begin{array}{l}\text { FC } \\
(\%)\end{array}$ & $\begin{array}{l}\text { Ash } \\
(\%)\end{array}$ & $\begin{array}{c}\text { Moisture } \\
(\%)\end{array}$ \\
\hline IN : & Fer Coal & 100.0 & 32.6 & $36 .$. & 4.9 & 26.3 \\
\hline OUT: & $\begin{array}{l}\text { Product } \\
\text { Volatiles } \\
\text { Ent. Solids } \\
\text { Moisture }\end{array}$ & $\begin{array}{l}100.0 \\
100.0 \\
100.0 \\
100.0\end{array}$ & $\begin{array}{r}34.9 \\
100.0 \\
43.3 \\
0.0\end{array}$ & $\begin{array}{r}57.4 \\
0.0 \\
49.0 \\
0.0\end{array}$ & $\begin{array}{l}7.5 \\
0.0 \\
7.1 \\
0.0\end{array}$ & $\begin{array}{r}0.2 \\
0.0 \\
0.6 \\
100.0\end{array}$ \\
\hline
\end{tabular}

EXPERIMFNTAL YIELD SUMMARY

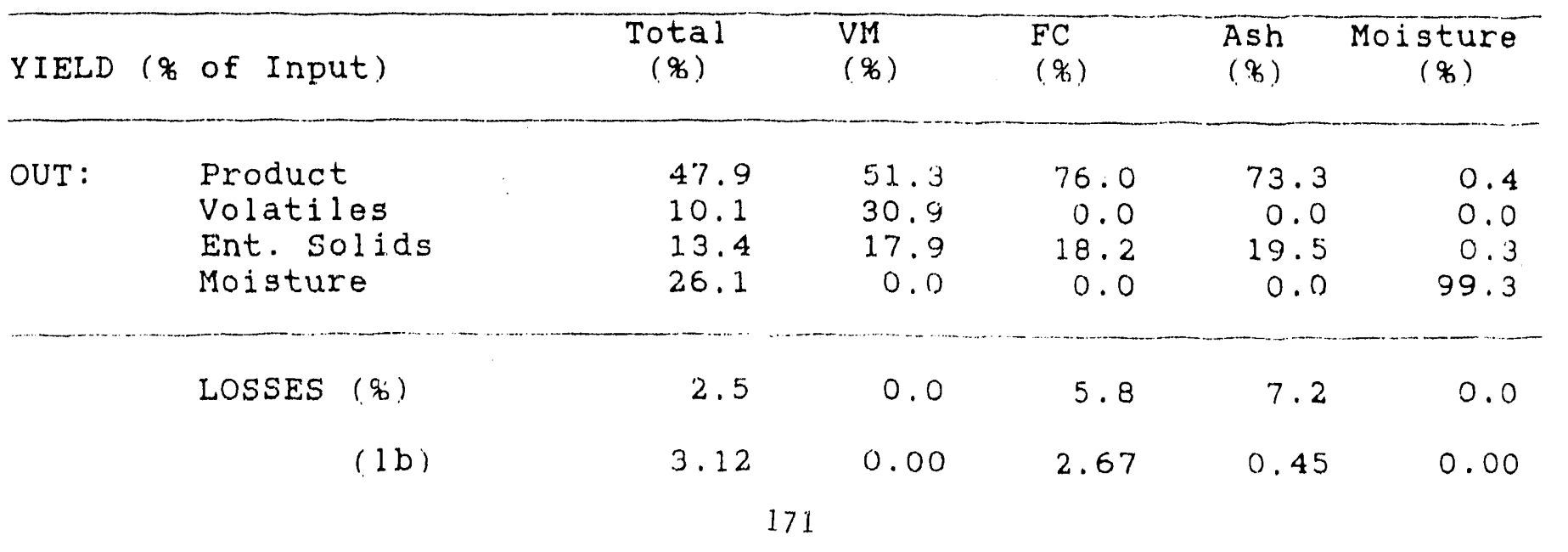


ATOMIC BALANCE FOR COAL DRYING EXPERIMENT: D-37 DAF

EAGLE BUTTE COAL

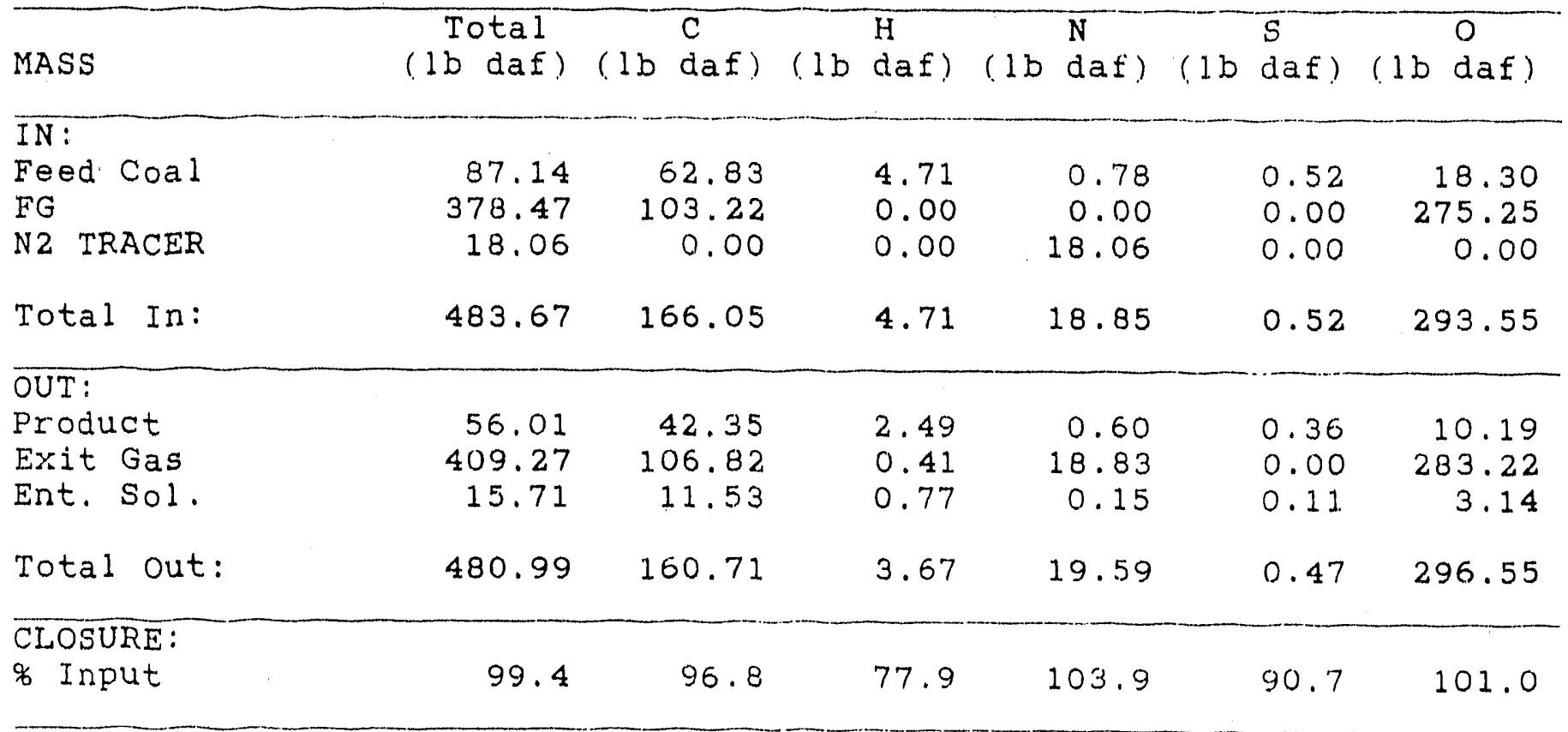

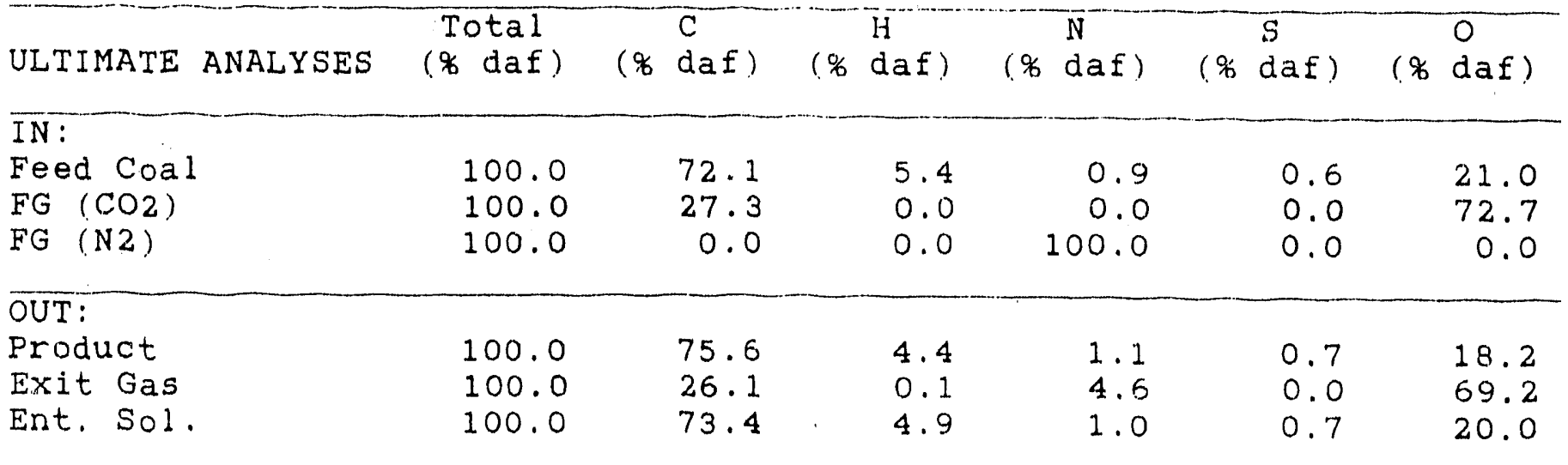


ENERGY BALANCE FOR COAL DRYING EXPERIMENT: D-37

EAGLE BUTTE COAL

Exp. Duration, hr:

13.6

\begin{tabular}{ccccc}
\hline Total & Mass & Sensible t Latent & Heat Content \\
Energy, & Rate, & Heat & mbtu/hr \\
mbtu/hr & $1 \mathrm{~b} / \mathrm{hr}$ & $\mathrm{btu} / \mathrm{hr}$ & $\mathrm{m}$
\end{tabular}

IN : (T ref, $60 \mathrm{~F})$

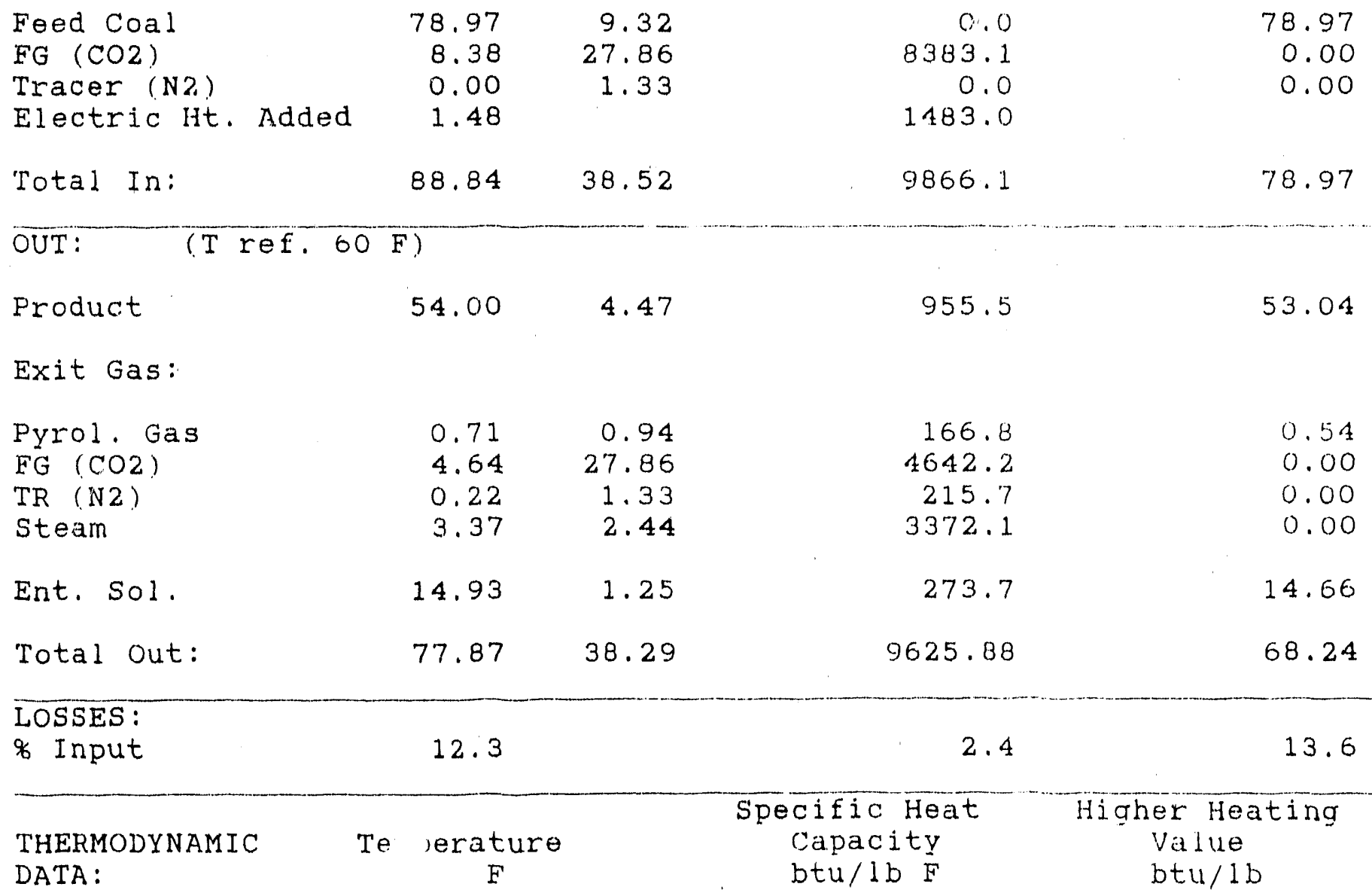

IN: $\quad(T$ ref. $60 \mathrm{~F})$

Feed Coal

FG ( $\mathrm{CO} 2)$

Tracer (N2)
60
1112
60

0.350

0. 286

0.249
8470

0

OTT: $\quad(\mathrm{T}$ ref. $60 \mathrm{~F})$

Product

671

0.350

11872

Exit Gas:

Pyrol. Gas

FG ( $\left.\mathrm{CO}_{2}\right)$

Tacer (N2)

steam

684

684

0.285

0.267

684

0. 260

684

0.492

Ent. Sol.

684

0.350

11697 
MATERIAL BALANCE FOR COAL DRYING EXPERIMENT: D-38

\begin{tabular}{|c|c|c|c|c|c|c|}
\hline MASS & & $\begin{array}{l}\text { Total } \\
\text { (1b) }\end{array}$ & $\begin{array}{l}V M \\
(\mathrm{lb})\end{array}$ & $\begin{array}{l}\mathrm{FC} \\
(1 \mathrm{~b})\end{array}$ & $\begin{array}{l}\text { Ash } \\
(1 \mathrm{~b})\end{array}$ & $\begin{array}{c}\text { Moisture } \\
\text { (1b) }\end{array}$ \\
\hline IN : & Feed Coal & 131.72 & 49.13 & 44.92 & 14.09 & 23.58 \\
\hline \multirow[t]{2}{*}{ OUT: } & $\begin{array}{l}\text { Product } \\
\text { Volatiles } \\
\text { Ent. Solids } \\
\text { Moisture }\end{array}$ & $\begin{array}{l}80.16 \\
13.49 \\
13.41 \\
23.48\end{array}$ & $\begin{array}{r}29.58 \\
13.49 \\
6.06 \\
0.00\end{array}$ & $\begin{array}{r}40.08 \\
0.00 \\
4.98 \\
0.00\end{array}$ & $\begin{array}{r}10.50 \\
0.00 \\
2.28 \\
0.00\end{array}$ & $\begin{array}{r}0.00 \\
0.00 \\
0.09 \\
23.48\end{array}$ \\
\hline & Total Out: & 130.55 & 49.13 & 45.06 & 12.78 & 23.58 \\
\hline CLOSURE & ( $\%$ of Input $):$ & 99.1 & 100.0 & 100.3 & 90.7 & 100.0 \\
\hline PROXIMATE & E ANALYSES & $\begin{array}{c}\text { Total } \\
(8)\end{array}$ & $\begin{array}{l}V M \\
(\%)\end{array}$ & $\begin{array}{l}\text { FC } \\
(\%)\end{array}$ & $\begin{array}{l}\text { Ash } \\
(\%)\end{array}$ & $\begin{array}{c}\text { Moisture } \\
(\%)\end{array}$ \\
\hline IN : & Feed Coâl & 100.0 & 37.3 & 34.1 & 10.7 & 17.9 \\
\hline OUT: & $\begin{array}{l}\text { Product } \\
\text { Volatiles } \\
\text { Ent. Solids } \\
\text { Moisture }\end{array}$ & $\begin{array}{l}100.0 \\
100.0 \\
100.0 \\
100.0\end{array}$ & $\begin{array}{r}36.9 \\
100.0 \\
45.2 \\
0.0\end{array}$ & $\begin{array}{r}50.0 \\
0.0 \\
37.1 \\
0.0\end{array}$ & $\begin{array}{r}13.1 \\
0.0 \\
17.0 \\
0.0\end{array}$ & $\begin{array}{r}0.0 \\
0.0 \\
0.7 \\
100.0\end{array}$ \\
\hline
\end{tabular}

EXPERIMENTAL YIELD SUMMARY

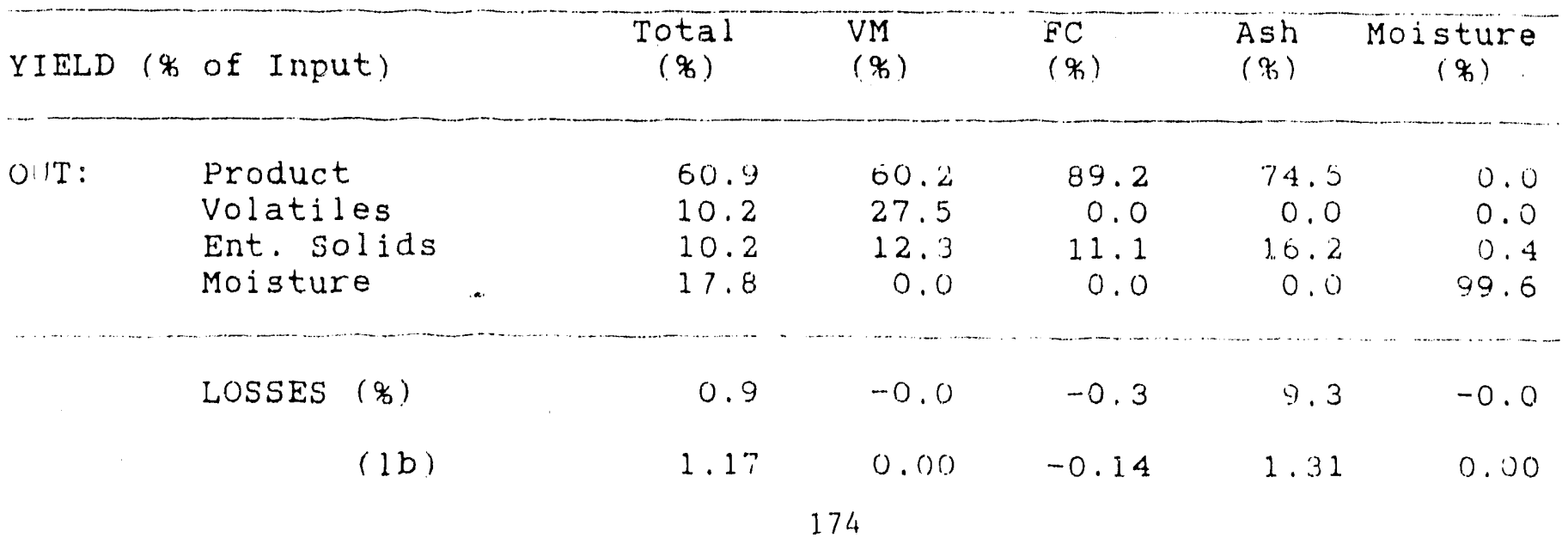


ATOMIC BALANCE FOR COAL DRYING EXPERIMENT: D-38 DAF

USIBELI.I COAL

\begin{tabular}{|c|c|c|c|c|c|c|c|}
\hline MASS & $\begin{array}{c}\text { Total } \\
(1 b \text { daf })\end{array}$ & $(1 \mathrm{~b}$ daf $)$ & $(1 \mathrm{~b}$ & $\begin{array}{l}\mathrm{H} \\
\mathrm{daf})\end{array}$ & (1b daf) & $\left(\begin{array}{ll} & S \\
\text { (1b daf }\end{array}\right)$ & $\left(\begin{array}{l}0 \\
\text { (1b daf }\end{array}\right)$ \\
\hline $\begin{array}{l}\text { IN: } \\
\text { Feed Coal } \\
\text { FG } \\
\text { N2 TRACER }\end{array}$ & $\begin{array}{r}94.05 \\
245.54 \\
15.63\end{array}$ & $\begin{array}{r}64.71 \\
66.97 \\
0.00\end{array}$ & & $\begin{array}{l}5.42 \\
0.00 \\
0.00\end{array}$ & $\begin{array}{r}0.94 \\
0.00 \\
15.63\end{array}$ & $\begin{array}{l}0.23 \\
0.00 \\
0.00\end{array}$ & $\begin{array}{r}22.76 \\
178.58 \\
0.00\end{array}$ \\
\hline Total In: & 355.22 & 121.67 & & 5.42 & 16.57 & 0.23 & 201.34 \\
\hline $\begin{array}{l}\text { JUT: } \\
\text { Product } \\
\text { Exit Gas } \\
\text { Ent. Sol. }\end{array}$ & $\begin{array}{r}69.66 \\
274.66 \\
11.04\end{array}$ & $\begin{array}{r}51.13 \\
70.59 \\
7.90\end{array}$ & & $\begin{array}{l}3.27 \\
0.27 \\
0.56\end{array}$ & $\begin{array}{r}0.70 \\
15.66 \\
0.11\end{array}$ & $\begin{array}{l}0.21 \\
0.00 \\
0.02\end{array}$ & $\begin{array}{r}14.35 \\
188.14 \\
2.44\end{array}$ \\
\hline Total out: & 355.36 & 129.62 & & 4.11 & 16.46 & 0.23 & 204.93 \\
\hline $\begin{array}{l}\text { CLOSURE: } \\
\text { \% Input }\end{array}$ & 100.0 & 98.4 & & 75.9 & 99.4 & 102.4 & 101.8 \\
\hline ULTIMATE ANALYSES & $\begin{array}{l}\text { Total } \\
(\% \text { daf })\end{array}$ & $\begin{array}{l}\mathrm{C} \\
(\% \mathrm{daf})\end{array}$ & $(\%$ & $\begin{array}{l}\mathrm{H} \\
\text { daf ) }\end{array}$ & $(\%$ daf $)$ & $\left(\begin{array}{l}S \\
\text { daf })\end{array}\right.$ & $\left(\begin{array}{l}0 \\
\text { daf })\end{array}\right.$ \\
\hline $\begin{array}{l}\text { IN: } \\
\text { Feed Coal } \\
\text { FG (CO2) } \\
\text { FG (N2) }\end{array}$ & $\begin{array}{l}100.0 \\
100.0 \\
100.0\end{array}$ & $\begin{array}{r}68.8 \\
27.3 \\
6.0\end{array}$ & & $\begin{array}{l}5.8 \\
0.0 \\
0.0\end{array}$ & $\begin{array}{r}1.0 \\
0.0 \\
100.0\end{array}$ & $\begin{array}{l}0.2 \\
0.0 \\
0.0\end{array}$ & $\begin{array}{r}24.2 \\
72.7 \\
0.0\end{array}$ \\
\hline $\begin{array}{l}\text { OUT: } \\
\text { Product } \\
\text { Exit Gas } \\
\text { Ent. Sol. }\end{array}$ & $\begin{array}{l}100.0 \\
100.0 \\
100.0\end{array}$ & $\begin{array}{l}73.4 \\
25.7 \\
71.6\end{array}$ & & $\begin{array}{l}4.7 \\
0.1 \\
5.1\end{array}$ & $\begin{array}{l}1.0 \\
5.7 \\
1.0\end{array}$ & $\begin{array}{l}0.3 \\
0.0 \\
0.2\end{array}$ & $\begin{array}{l}20.6 \\
68.5 \\
22.1\end{array}$ \\
\hline
\end{tabular}


ENERGY BALANCE FOR COAL DRYING EXPERIMENT: D-38

USIBELLI COAL

Exp. Duration, hr:

11.8

\begin{tabular}{|c|c|c|c|c|}
\hline & Total & Mass & ensible + Latent & \\
\hline ENERGY & $\begin{array}{l}\text { Energy, } \\
\text { mbtu/hr }\end{array}$ & $\begin{array}{l}\text { Rate, } \\
1 \mathrm{~b} / \mathrm{hr}\end{array}$ & $\begin{array}{l}\text { Heat } \\
\text { btu/hr }\end{array}$ & $\begin{array}{c}\text { Heat Content } \\
\text { mbtu/hr }\end{array}$ \\
\hline
\end{tabular}

IN: (T ref. $60 \mathrm{~F}$ )

$\begin{array}{lrr}\text { Feed Coal } & 94.95 & 11.21 \\ \text { FG (CO2) } & 6.42 & 20.90 \\ \text { Tracer (N2) } & 0.00 & 1.33 \\ \text { Electric Ht. Added } & 2.66 & \end{array}$

$\begin{array}{rr}0.0 & 94.95 \\ 6423.3 & 0.00 \\ 0.0 & 0.00\end{array}$

Total In:

$104.04 \quad 33.44$

2662.0

OUT: $\quad(\mathrm{T}$ ref. $60 \mathrm{~F})$

Product

75.26

6.82

1344.3

73.91

Exit Gas:

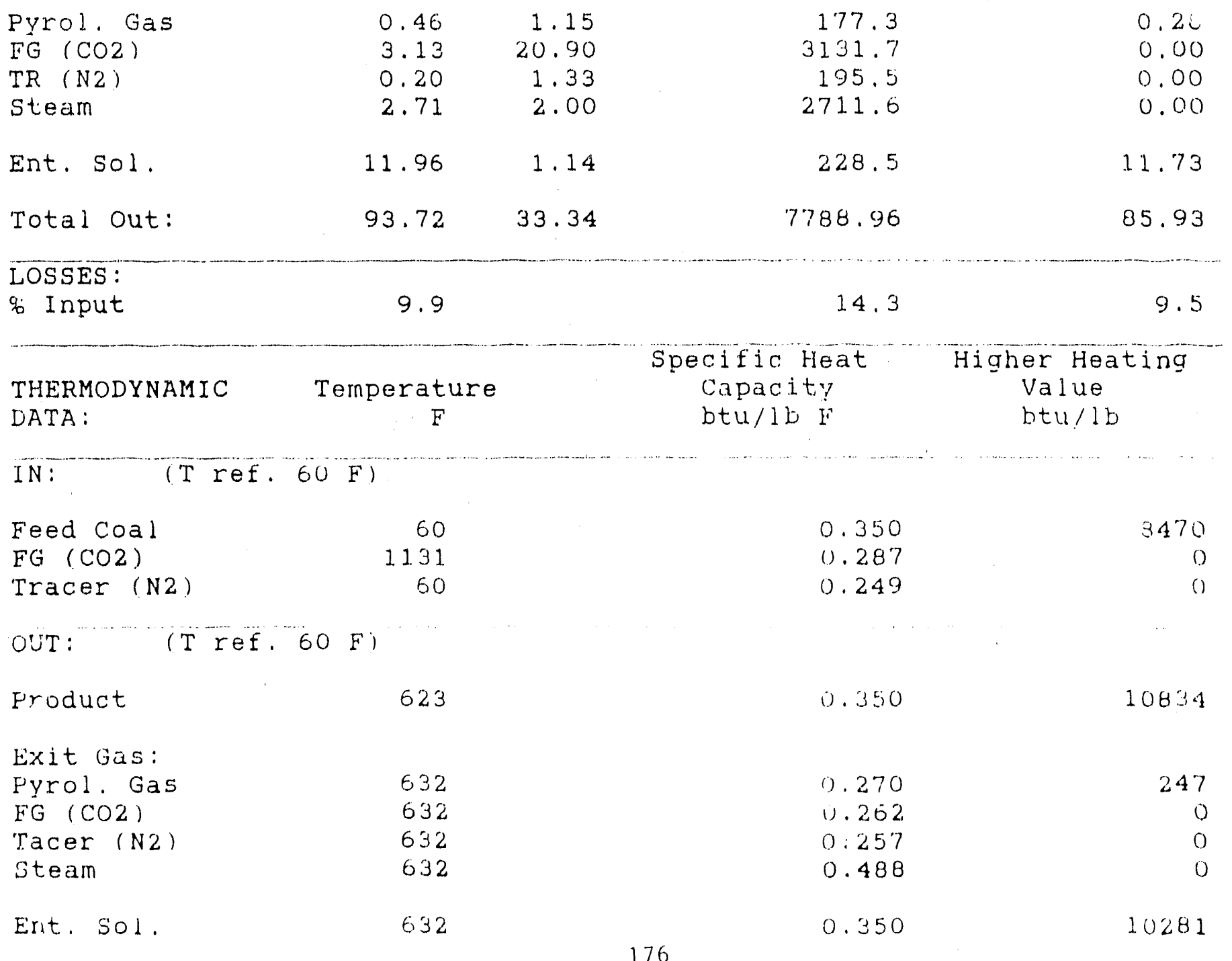


MATERLAL BALANCE FOR COAL DRYING EXPERIMENT: D-39

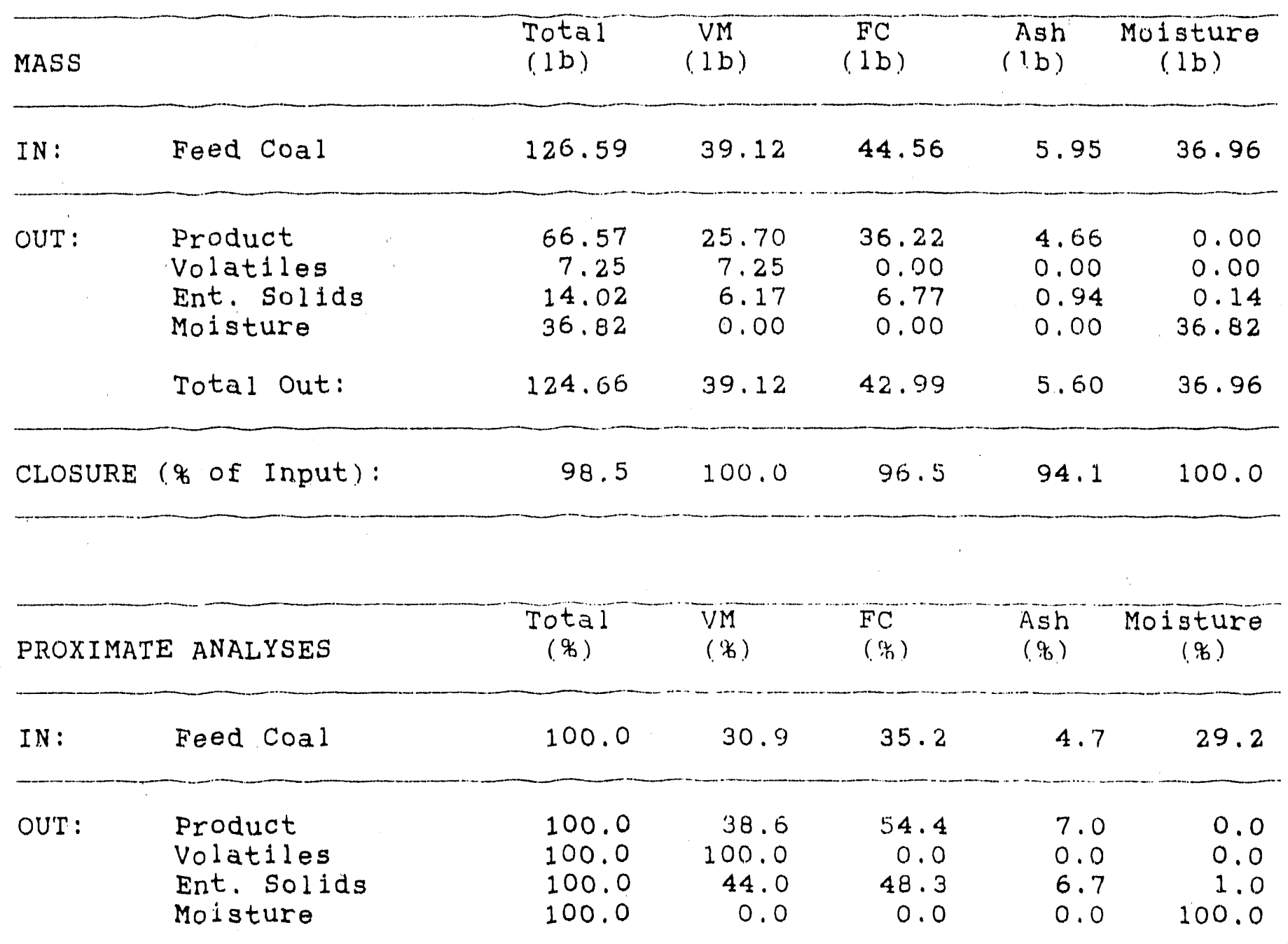

EXPERIMENTAL YIELD SUMMARY

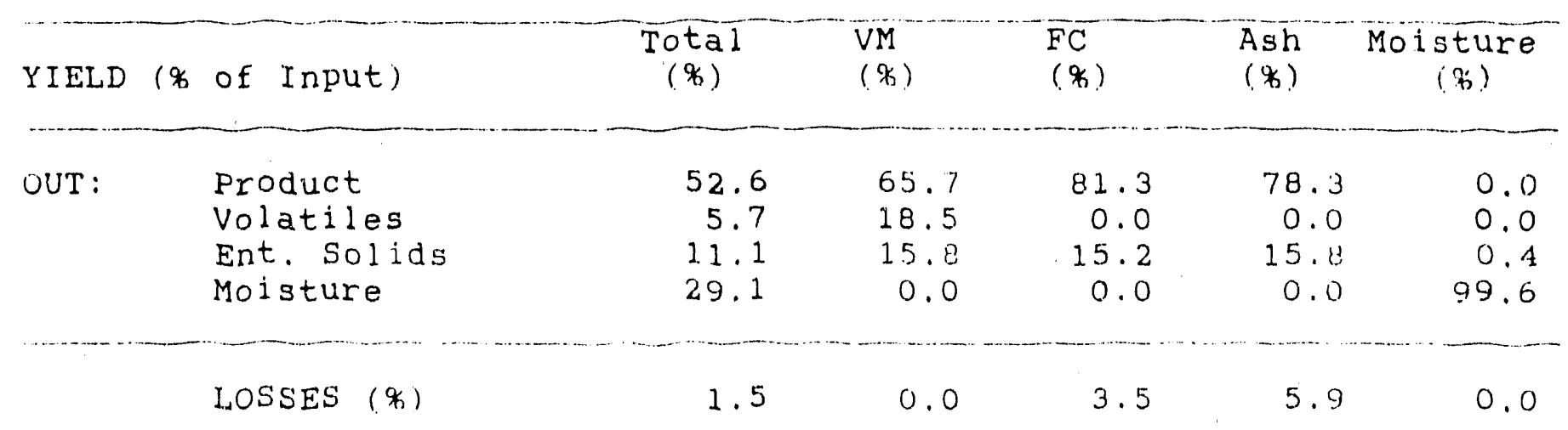

(lb)

1.92

0.00

1.57

0.35

0.00 
ATOMIC BALANCE FOR COAL DRYING EXPERIMENT: D-39 DAF

EAGLE BUTTE COAL

\begin{tabular}{|c|c|c|c|c|c|c|c|c|}
\hline MASS & $\begin{array}{c}\text { Total } \\
\text { (1b daf })\end{array}$ & 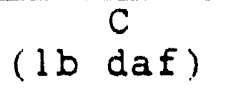 & $(1 \mathrm{~b}$ & $\begin{array}{l}\text { H } \\
\text { daf) }\end{array}$ & $(1 \mathrm{~b}$ daf $)$ & $(1 b$ & $\begin{array}{l}S \\
d a f\end{array}$ & ( Ib daf $)$ \\
\hline $\begin{array}{l}\text { IN: } \\
\text { Feed Coal } \\
\text { FG } \\
\text { N2 TRACER }\end{array}$ & $\begin{array}{r}83.68 \\
192.60 \\
17.51\end{array}$ & $\begin{array}{r}60.33 \\
52.53 \\
0.00\end{array}$ & & $\begin{array}{l}4.52 \\
0.00 \\
0.00\end{array}$ & $\begin{array}{r}0.75 \\
0.00 \\
17.51\end{array}$ & & $\begin{array}{l}0.50 \\
0.00 \\
0.00\end{array}$ & $\begin{array}{r}17.57 \\
140.07 \\
0.00\end{array}$ \\
\hline Total In: & 293.79 & 112.86 & & 4.52 & 18.26 & & 0.50 & 157.65 \\
\hline $\begin{array}{l}\text { OUT: } \\
\text { Product } \\
\text { Exit Gas } \\
\text { Ent. Sol. }\end{array}$ & $\begin{array}{r}61.92 \\
217.36 \\
12.94\end{array}$ & $\begin{array}{r}46.44 \\
54.77 \\
9.46\end{array}$ & & $\begin{array}{l}3.06 \\
0.22 \\
0.67\end{array}$ & $\begin{array}{r}0.68 \\
16.95 \\
0.13\end{array}$ & & $\begin{array}{l}0.37 \\
0.00 \\
0.09\end{array}$ & $\begin{array}{r}11.39 \\
145.41 \\
2.59\end{array}$ \\
\hline Total out: & 292.22 & 110.67 & & 3.95 & 17.76 & & 0.46 & 159.39 \\
\hline $\begin{array}{l}\text { CLOSURE: } \\
\text { \% Input }\end{array}$ & 99.5 & 98.1 & & 87.5 & 97.3 & & 92.0 & 101.1 \\
\hline ULTIMATE ANALYSES & $\begin{array}{l}\text { Total } \\
(\% \text { daf })\end{array}$ & $(\%$ daf $)$ & $(\%$ & $\begin{array}{l}\text { H } \\
\text { daf) }\end{array}$ & $\begin{array}{l}\mathrm{N} \\
(\% \text { daf })\end{array}$ & $(\%$ & $\begin{array}{l}\text { S } \\
\text { daf) }\end{array}$ & $\left(\begin{array}{l}0 \\
(\% \text { daf })\end{array}\right.$ \\
\hline $\begin{array}{l}\text { IN: } \\
\text { Feed Coal } \\
\text { FG (CO2) } \\
\text { FG (N2) }\end{array}$ & $\begin{array}{l}100.0 \\
100.0 \\
100.0\end{array}$ & $\begin{array}{r}72.1 \\
27.3 \\
0.0\end{array}$ & & $\begin{array}{l}5.4 \\
0.0 \\
0.0\end{array}$ & $\begin{array}{r}0.9 \\
0.0 \\
100.0\end{array}$ & & $\begin{array}{l}0.6 \\
0.0 \\
0.0\end{array}$ & $\begin{array}{r}21.0 \\
72.7 \\
0.0\end{array}$ \\
\hline $\begin{array}{l}\text { OUT: } \\
\text { Product } \\
\text { Exit Gas } \\
\text { Ent. Sol. }\end{array}$ & $\begin{array}{l}100.0 \\
100.0 \\
100.0\end{array}$ & $\begin{array}{l}75.0 \\
25.2 \\
73.1\end{array}$ & & $\begin{array}{l}4.9 \\
0.1 \\
5.2\end{array}$ & $\begin{array}{l}1.1 \\
7.8 \\
1.0\end{array}$ & & $\begin{array}{l}0.6 \\
0.0 \\
0.7\end{array}$ & $\begin{array}{l}18.4 \\
66.9 \\
20.0\end{array}$ \\
\hline
\end{tabular}


ENERGY BALANCE FOR COAL DRYING EXPERIMENT: D-39

EAGLE BUTTE COAL

Exp, Duration, hr:

13.2

\begin{tabular}{|c|c|c|c|c|}
\hline & Total & Mass & Sensjble + Latent & \\
\hline ENERG & $\begin{array}{l}\text { Energy. } \\
\text { mbtu/hr }\end{array}$ & $\begin{array}{l}\text { Rate, } \\
\text { lb/hr }\end{array}$ & $\begin{array}{l}\text { Heat } \\
\text { btu/hr }\end{array}$ & $\begin{array}{c}\text { Heat content } \\
\mathrm{mbt} u / \mathrm{hr}\end{array}$ \\
\hline
\end{tabular}

IN :

$(\mathrm{T}$ ref. $60 \mathrm{~F})$

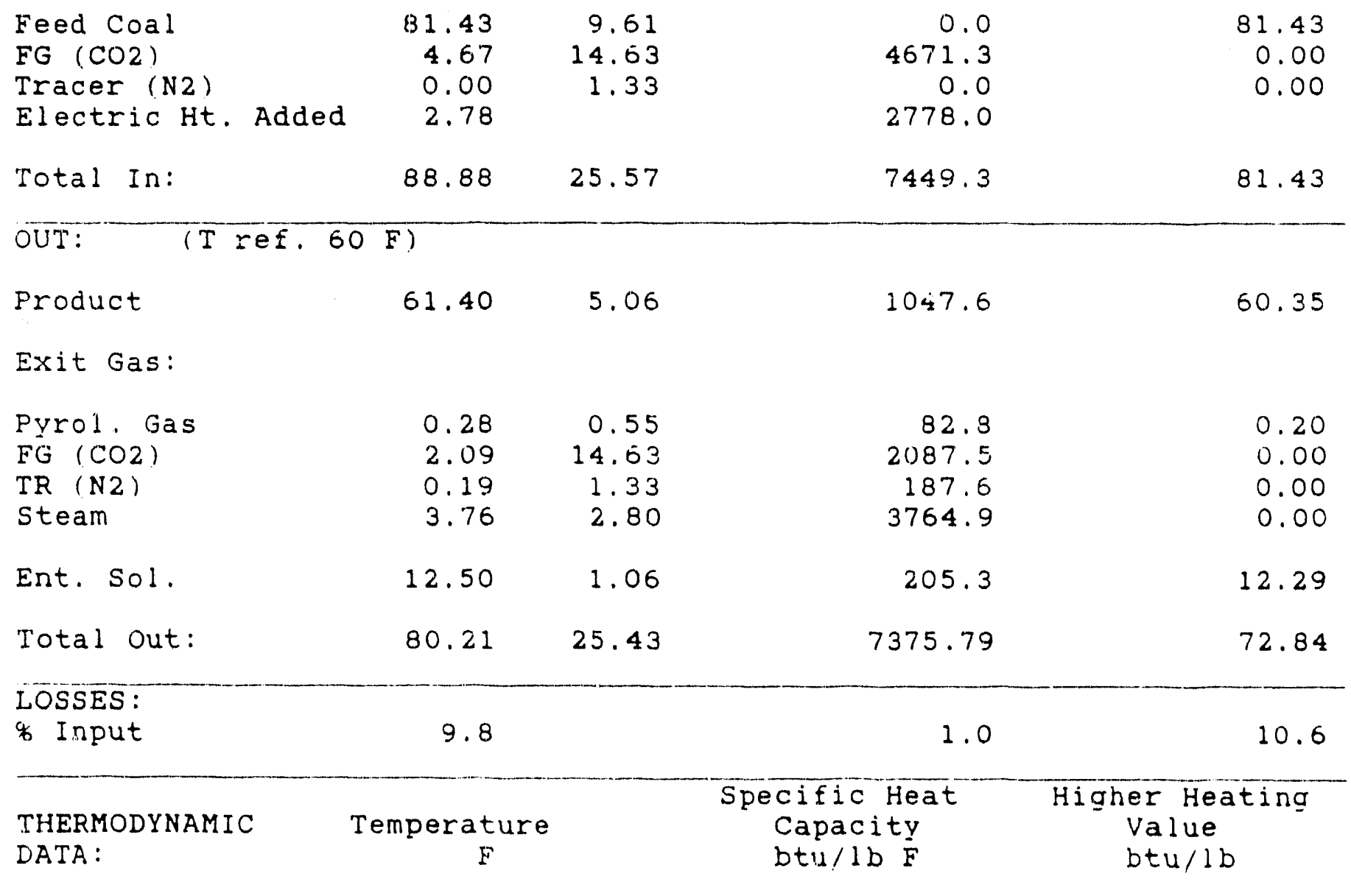

IN: $\quad(T$ ref. $60 \mathrm{~F})$

Feed Coal

FG ( $\mathrm{CO} 2)$

60

1165

0.350

0.289

8470

Tracer (N2)

60

o. 249

OUT: (T ref. $60 \mathrm{~F})$

Product

.52

0.350

11936

Exit Gr:

Pyrol. Gas

611

611

FG ( $\mathrm{CO} 2$ )

Tacer (N2)

Steam

0.273

0. 259

0.256

0.487

355

Ent. Sol.

511

0.350 
MATERIAL BALANCE FOR CJAL DRYING EXPERIMENT: D-48

\begin{tabular}{|c|c|c|c|c|c|c|}
\hline MASS & & $\begin{array}{l}\text { Total } \\
\text { (1 b) }\end{array}$ & $\begin{array}{l}V M \\
(1 \mathrm{~b})\end{array}$ & $\begin{array}{l}\mathrm{FC} \\
(\mathrm{lb})\end{array}$ & $\begin{array}{l}\text { Ash } \\
(1 \mathrm{~b})\end{array}$ & $\begin{array}{c}\text { Moisture } \\
\text { (ib) }\end{array}$ \\
\hline IN : & Feed Coal & 55.73 & 20.83 & 19.00 & 4.75 & 11.15 \\
\hline \multirow[t]{2}{*}{ OUT: } & $\begin{array}{l}\text { Product } \\
\text { Volatiles } \\
\text { Ent. Solids } \\
\text { Moisture }\end{array}$ & $\begin{array}{r}38.60 \\
2.07 \\
3.08 \\
10.76\end{array}$ & $\begin{array}{r}17.45 \\
2.07 \\
1.31 \\
0.00\end{array}$ & $\begin{array}{r}16.48 \\
0.00 \\
1.13 \\
0.00\end{array}$ & $\begin{array}{l}4.40 \\
0.00 \\
0.52 \\
0.00\end{array}$ & $\begin{array}{r}0.27 \\
0.00 \\
0.11 \\
10.76\end{array}$ \\
\hline & Total Out: & 54.51 & 20.83 & 17.62 & 4.92 & 11.15 \\
\hline CLOS & of In & 97.8 & 100.0 & 92.7 & 103.6 & 100.0 \\
\hline
\end{tabular}

\begin{tabular}{llrrrrr} 
PROXIMATE ANALYSES & $\begin{array}{c}\text { Total } \\
(\%)\end{array}$ & $\begin{array}{l}\text { VM } \\
(\%)\end{array}$ & $\begin{array}{l}\text { FC } \\
(\%)\end{array}$ & $\begin{array}{c}\text { Ash } \\
(\%)\end{array}$ & $\begin{array}{c}\text { Moisture } \\
(\%)\end{array}$ \\
\hline IN: & Feed Coal & 100.0 & 37.4 & 34.1 & 8.5 & 20.0 \\
\hline \multirow{2}{*}{ OUT: } & Product & 100.0 & 45.2 & 42.7 & 11.4 & 0.7 \\
& Volatiles & 100.0 & 100.0 & 0.0 & 0.0 & 0.0 \\
& Ent. Solids & 100.0 & 42.7 & 36.8 & 16.9 & 3.0 \\
& Moisture & 100.0 & 0.0 & 0.0 & 0.0 & 100.0
\end{tabular}

EXPERIMENTAL YIELD SUMMARY

\begin{tabular}{|c|c|c|c|c|c|c|}
\hline YIELD & ( $\%$ of Input) & $\begin{array}{c}\text { Total } \\
\left(w_{1}\right)\end{array}$ & $\begin{array}{l}V M 1 \\
\left(q_{1}\right)\end{array}$ & $\begin{array}{l}F C \\
(\beta)\end{array}$ & $\begin{array}{l}\text { Ash } \\
(\%)\end{array}$ & $\begin{array}{c}\text { Moisture } \\
(\%)\end{array}$ \\
\hline \multirow[t]{3}{*}{ OUT: } & $\begin{array}{l}\text { Product } \\
\text { Volatiles } \\
\text { Ent. Solids } \\
\text { Moisture }\end{array}$ & $\begin{array}{r}69.3 \\
3.7 \\
5.5 \\
19.3\end{array}$ & $\begin{array}{r}33.0 \\
9.9 \\
6.3 \\
0.0\end{array}$ & $\begin{array}{l}30.0 \\
0.0 \\
0.0 \\
0.0\end{array}$ & $\begin{array}{r}92.0 \\
0.0 \\
11.0 \\
0.0\end{array}$ & $\begin{array}{r}2.4 \\
0.0 \\
1.0 \\
96.6\end{array}$ \\
\hline & LOSSES $(i ;$ & 2.2 & 0.0 & $\therefore$ & -3.6 & -0.0 \\
\hline & (1b) & 1.21 & 0.00 & 1.38 & -0.17 & 0.00 \\
\hline
\end{tabular}


ATOMIC BALANCE FOR COAL DRYING EXPERIMENT: D-48 DAF

USIBELLI COAL

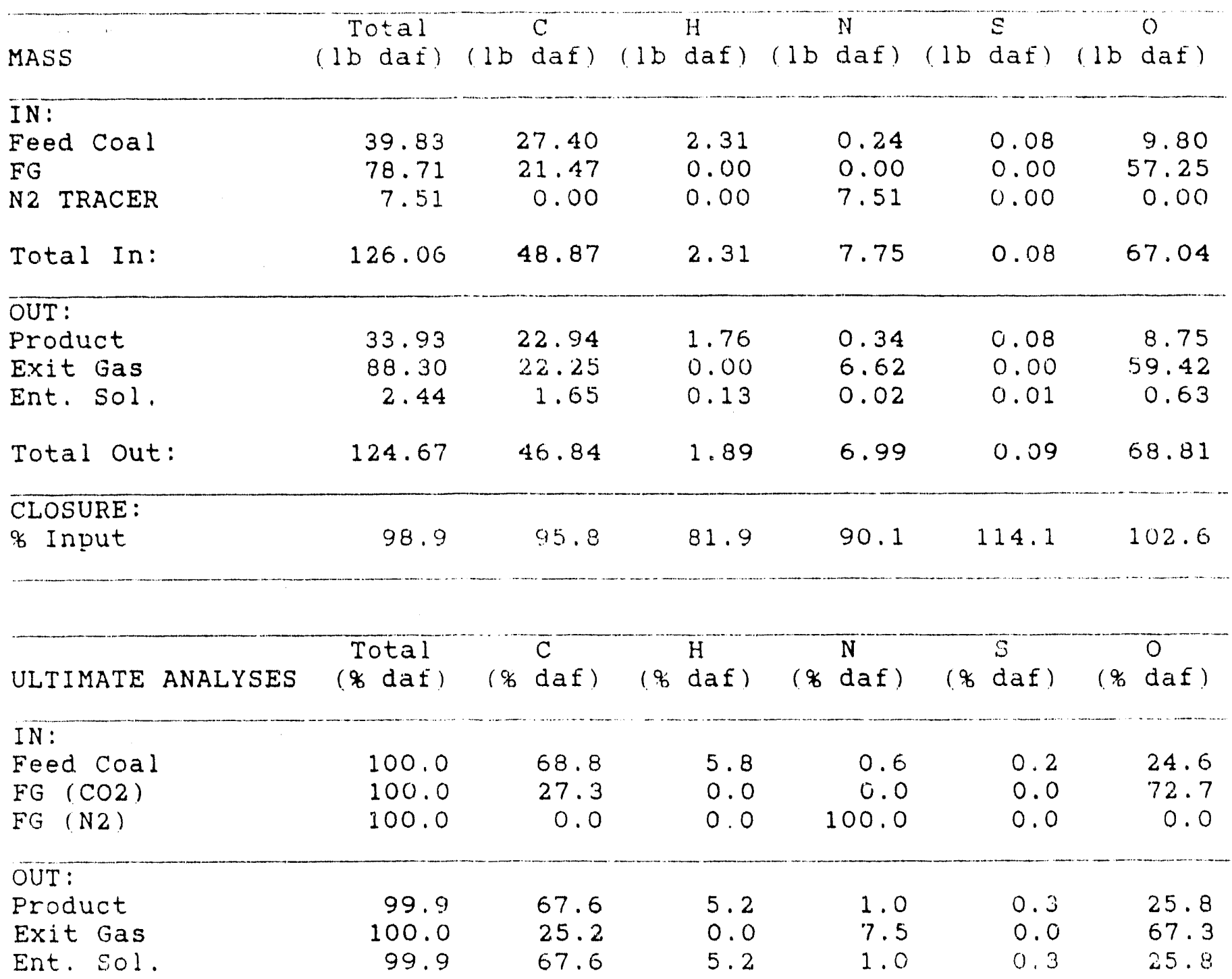


ENERGY BALANCE FOR COAL DRYING EXPERIMENT: D-48

USIBELLI COAL

Exp. Duration, hr:

5.7

\begin{tabular}{|c|c|c|c|c|}
\hline ENERGY & $\begin{array}{l}\text { Lotal } \\
\text { Energy } \\
\text { mbtu/hr }\end{array}$ & $\begin{array}{l}\text { Mass } \\
\text { Rate } \\
\text { lb/hr }\end{array}$ & $\begin{array}{c}\text { sensidie t Latent } \\
\text { Heat } \\
\text { btu/hr }\end{array}$ & $\begin{array}{c}\text { Heat content } \\
\text { mbtu/hr }\end{array}$ \\
\hline
\end{tabular}

IN: $\quad(T$ ref. $60 \mathrm{~F})$

$\begin{array}{lrrrr}\text { Feed Coal } & 83.55 & 9.86 & 0.0 & 83.55 \\ \text { FG (CO2) } & 3.55 & 13.93 & 3552.5 & 0.00 \\ \text { Tracer (N2) } & 0.00 & 1.33 & 0.0 & 0.00 \\ \text { Electric Ht. Added } & 2.37 & & 2366.0 & \end{array}$

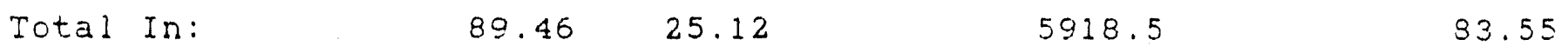

OUT: $(\mathrm{Tref} .60 \mathrm{~F})$

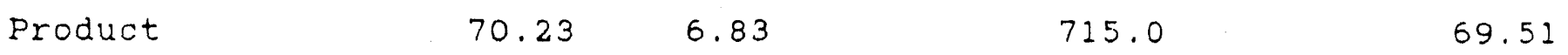

Exit Gas:

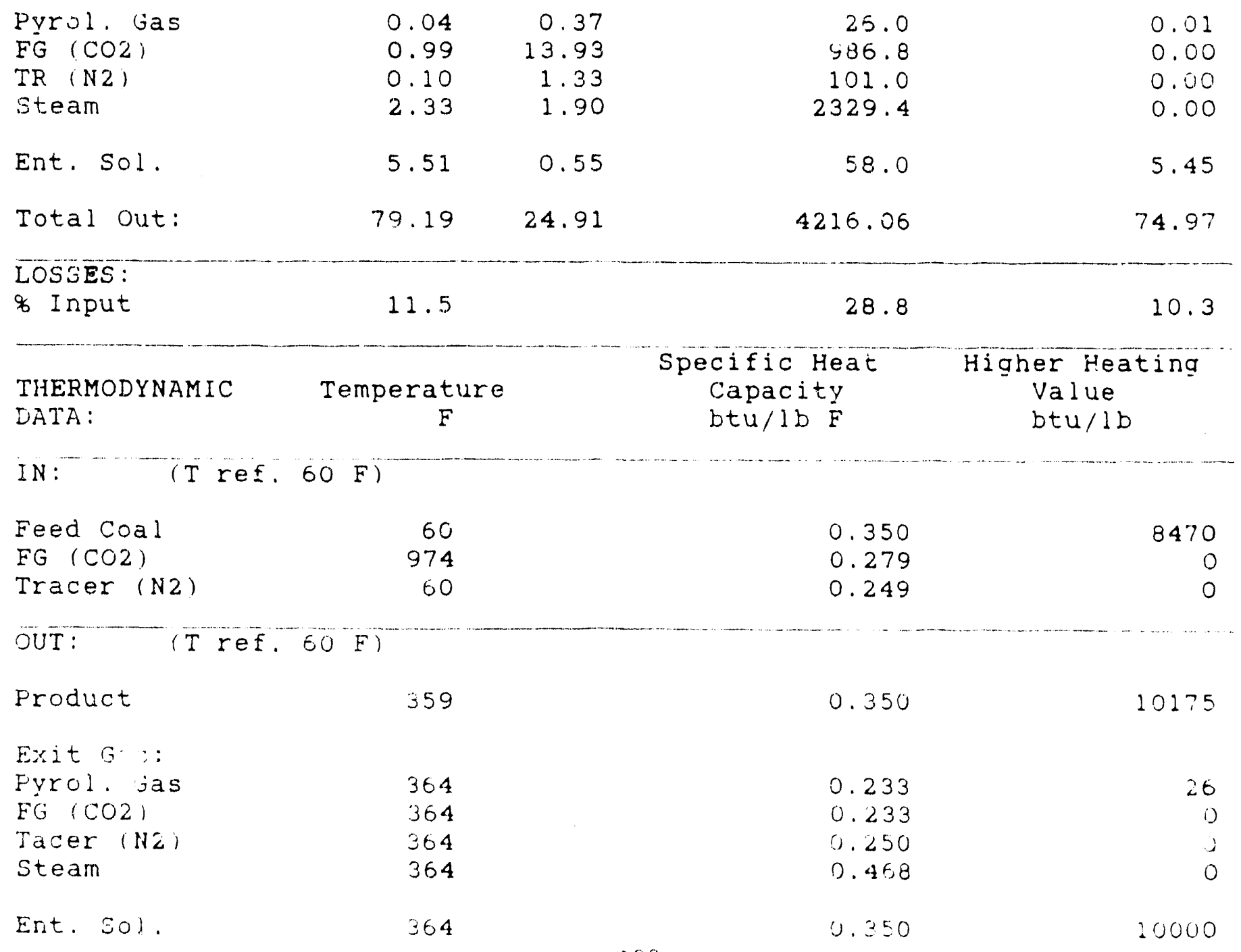


MATERIAL BALANCE FOR COAL DRYING EXPERIMENT: D-49

\begin{tabular}{|c|c|c|c|c|c|}
\hline MASS & $\begin{array}{l}\text { Total } \\
\text { (lb) }\end{array}$ & $\begin{array}{l}V M \\
(1 \mathrm{~b})\end{array}$ & $\begin{array}{l}F C \\
(1 \mathrm{~b})\end{array}$ & $\begin{array}{l}\text { Ash } \\
(1 \mathrm{~b})\end{array}$ & $\begin{array}{c}\text { Moisture } \\
\text { (Ib) }\end{array}$ \\
\hline Feed Coal & 55.73 & 18.42 & 20.86 & 2.85 & 13.60 \\
\hline $\begin{array}{l}\text { Product } \\
\text { Volatiles } \\
\text { Ent. Solids } \\
\text { Moisture }\end{array}$ & $\begin{array}{r}35.46 \\
0.49 \\
5.64 \\
13.32\end{array}$ & $\begin{array}{r}15.57 \\
0.49 \\
2.36 \\
0.00\end{array}$ & $\begin{array}{r}17.45 \\
0.00 \\
2.69 \\
0.00\end{array}$ & $\begin{array}{l}2.38 \\
0.00 \\
0.39 \\
0.00\end{array}$ & $\begin{array}{r}0.07 \\
0.00 \\
0.20 \\
13.32\end{array}$ \\
\hline Total out: & 54.91 & 18.42 & 20.13 & 2.76 & 13.50 \\
\hline CLOSURE ( $\%$ of Input $):$ & 98.5 & 100.0 & 96.5 & 96.9 & 100.0 \\
\hline PROXIMATE ANALYSES & $\begin{array}{c}\text { Total } \\
(\%)\end{array}$ & $\begin{array}{l}V M \\
(c)\end{array}$ & $\begin{array}{l}F C \\
(\%)\end{array}$ & $\begin{array}{l}\text { Ash } \\
(\%)\end{array}$ & $\begin{array}{c}\text { Moisture } \\
(\%)\end{array}$ \\
\hline Feed Coal & 100.0 & 33.1 & 37.4 & 5.1 & 24.4 \\
\hline $\begin{array}{l}\text { Product } \\
\text { Volatiles } \\
\text { Ent. Solids } \\
\text { Moisture }\end{array}$ & $\begin{array}{l}100.0 \\
100.0 \\
100.0 \\
100.0\end{array}$ & $\begin{array}{r}43.9 \\
100.0 \\
41.9 \\
0.0\end{array}$ & $\begin{array}{r}49.2 \\
0.0 \\
47.6 \\
0.0\end{array}$ & $\begin{array}{l}6.7 \\
0.0 \\
6.9 \\
0.0\end{array}$ & $\begin{array}{r}0.2 \\
0.0 \\
3.6 \\
100.0\end{array}$ \\
\hline
\end{tabular}

EXPERIMENTAL YIELD SUMMARY

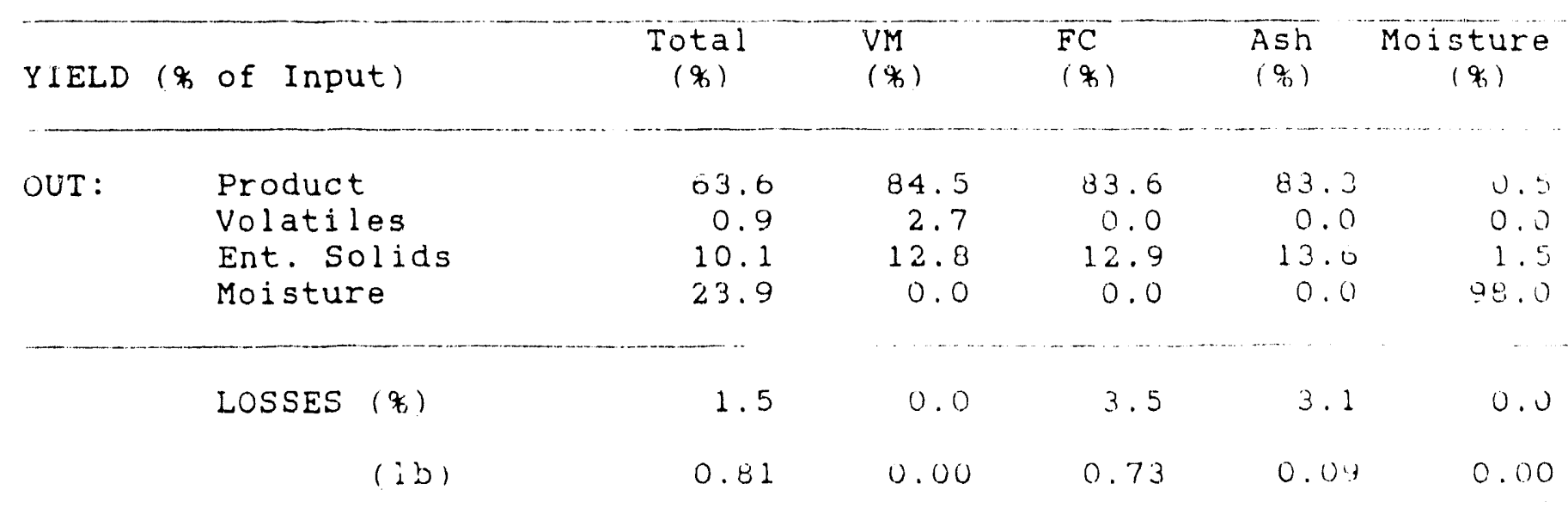


ENERGY BALANCE FOR COAL DRYING EXPERIMENT: D-49

EAGLE BUTTE COAL

$\begin{array}{lll}\text { Eotal } & \text { Mass sensible t Latent } \\ \text { Energy, } & \text { Rate, } & \text { Heat } \\ \text { mbtu/hr } & \text { lb/hr } & \text { btu/hr }\end{array}$

Exp. Duration, hr:

5.6

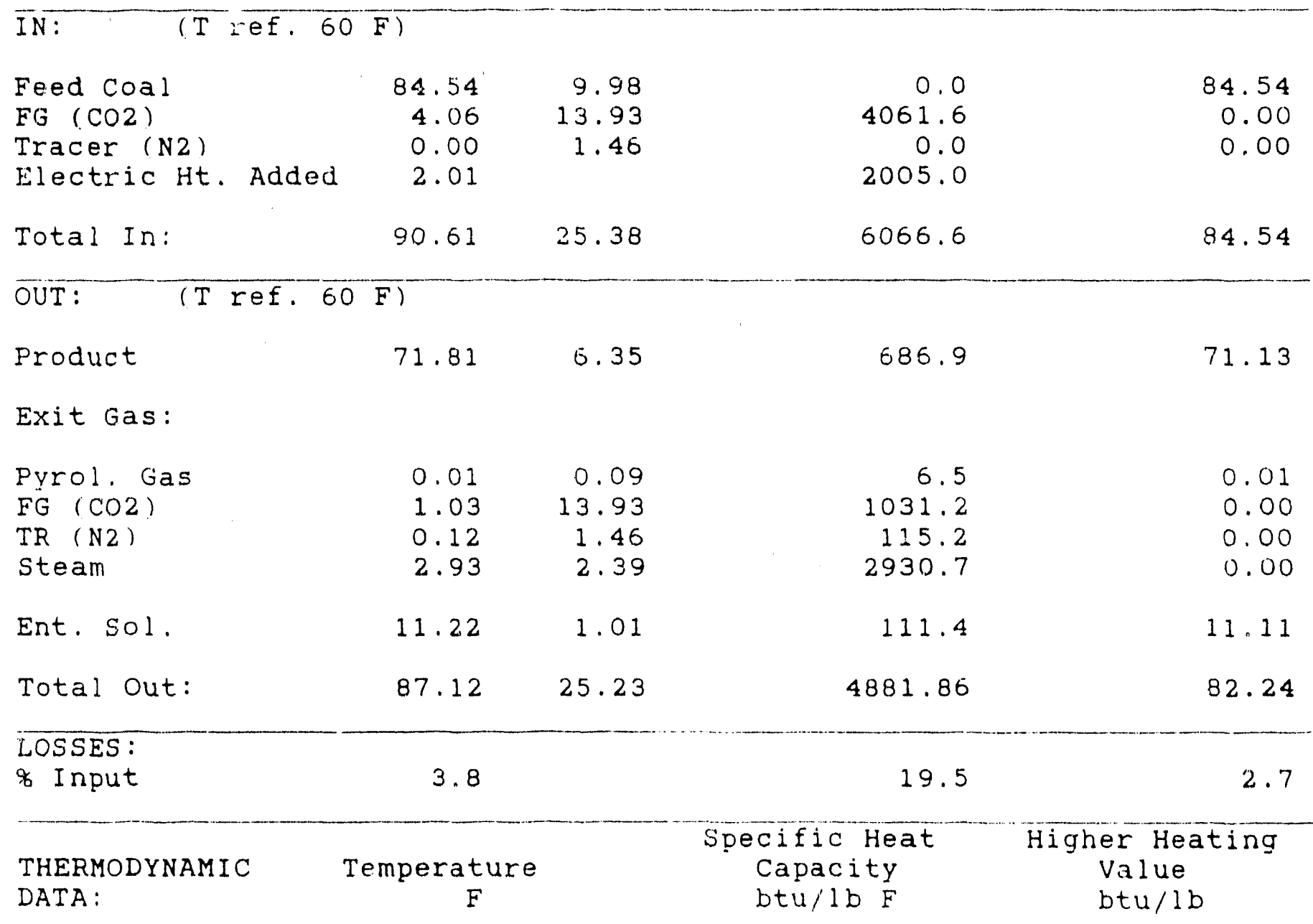

IN: $\quad(\mathrm{T}$ ref. $60 \mathrm{~F})$

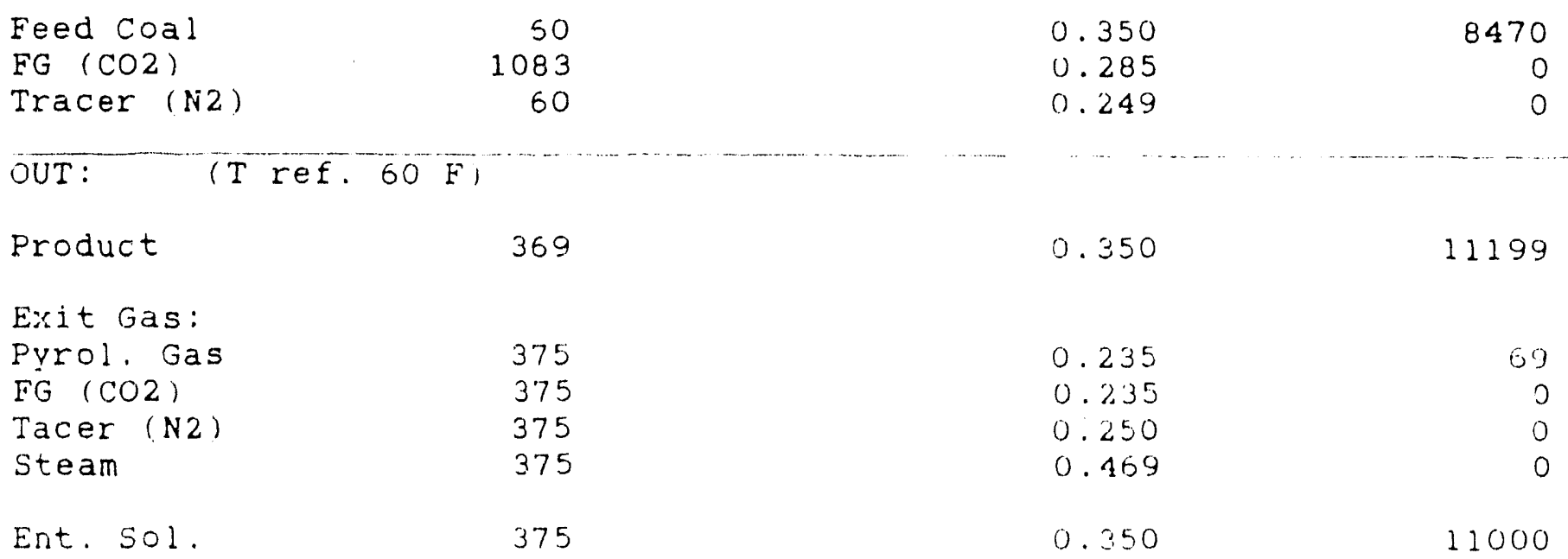

Heat Content $\mathrm{mbtu} / \mathrm{hr}$ 
ATOMIC BALANCE FOR COAL DRYING EXPERIMENT: D-49 DAF EAGLE BUTTE COAL

$\begin{array}{llllll}\text { Total } & C & \mathrm{H} & \mathrm{N} & \mathrm{S} & \mathrm{O}\end{array}$ (lb daf) (lb daf) (lb daf) ( lb daf) (lb daf) (lb daf)

MASS

IN :

Feed Coal

FG

N2 TRACER

Total In:

OUT:

Product

Exit Gas

Ent. Sol.

Total out:

CLOSURE:

$\%$ Input

$\begin{array}{rr}39.28 & 28.32 \\ 77.78 & 21.21 \\ 8.17 & 0.00\end{array}$

2.12

0.00

0.00

49.53

2.12

125.23

$33.02 \quad 23.21$

86.44

21.35

3.55

5.05

124.51

48.11

1.68

0.00

0.26

0.35

0.00

0.24

0.00

8.25

8.17

0.00

56.57

0.00

$8.52 \quad 0.24$

64.82

$\begin{array}{lrr}0.33 & 0.23 & 7.56 \\ 8.13 & 0.00 & 56.96 \\ 0.05 & 0.04 & 1.16\end{array}$

B. 51

0.27

65.68
$99.4 \quad 97.1$

91.5

99.8

113.1

101.3

\begin{tabular}{|c|c|c|c|c|c|c|c|c|}
\hline ULTIMATE ANALYSES & $\begin{array}{l}\text { Total } \\
(9 \text { daf })\end{array}$ & $(\%$ & daf) & $(\%$ daf $)$ & $\left(\begin{array}{l}\mathrm{N} \\
\text { daf })\end{array}\right.$ & $(\%$ daf $)$ & $(\%$ & $\begin{array}{l}0 \\
\text { daf }\end{array}$ \\
\hline $\begin{array}{l}\text { IN: } \\
\text { Feed Coal } \\
\text { FG (CO2) } \\
\text { FG (N2) }\end{array}$ & $\begin{array}{l}100.0 \\
100.0 \\
100.0\end{array}$ & & $\begin{array}{r}72.1 \\
27.3 \\
0.0\end{array}$ & $\begin{array}{l}5.4 \\
0.0 \\
0.0\end{array}$ & $\begin{array}{r}0.9 \\
0.0 \\
100.0\end{array}$ & $\begin{array}{l}0.6 \\
0.0 \\
0.0\end{array}$ & & $\begin{array}{r}21.0 \\
72.7 \\
0.0\end{array}$ \\
\hline $\begin{array}{l}\text { OUT: } \\
\text { Product } \\
\text { Exit Gas } \\
\text { Ent. Sol. }\end{array}$ & $\begin{array}{l}100.0 \\
100.0 \\
100.0\end{array}$ & & $\begin{array}{l}70.3 \\
24.7 \\
70.3\end{array}$ & $\begin{array}{l}5.1 \\
0.0 \\
5.1\end{array}$ & $\begin{array}{l}1.0 \\
9.4 \\
1.0\end{array}$ & $\begin{array}{l}0.7 \\
0.0 \\
0.7\end{array}$ & & $\begin{array}{l}22.9 \\
65.9 \\
22.9\end{array}$ \\
\hline
\end{tabular}


MATERIAL BALANCE FOR COAL DRYTNG EXPERIMENT: D-52

\begin{tabular}{|c|c|c|c|c|c|c|}
\hline MASS & & $\begin{array}{l}\text { Total } \\
(1 \mathrm{~b})\end{array}$ & $\begin{array}{l}V M \\
(1 \mathrm{~b})\end{array}$ & $\begin{array}{l}F C \\
(1 \mathrm{~b})\end{array}$ & $\begin{array}{l}\text { Ash } \\
(1 b)\end{array}$ & $\begin{array}{c}\text { Moisture } \\
\text { (1b) }\end{array}$ \\
\hline IN : & Feed Coal & 136.78 & 53.35 & 48.97 & 13.27 & 21.20 \\
\hline \multirow[t]{2}{*}{ OUT: } & $\begin{array}{l}\text { Product } \\
\text { Volatiles } \\
\text { Ent. Solids } \\
\text { Moisture }\end{array}$ & $\begin{array}{r}82.42 \\
20.93 \\
8.61 \\
21.07\end{array}$ & $\begin{array}{r}28.68 \\
20.93 \\
3.73 \\
0.00\end{array}$ & $\begin{array}{r}42.20 \\
0.00 \\
3.49 \\
0.00\end{array}$ & $\begin{array}{r}11.46 \\
0.00 \\
1.34 \\
0.00\end{array}$ & $\begin{array}{r}0.08 \\
0.00 \\
0.05 \\
21.07\end{array}$ \\
\hline & Total out: & 133.03 & 53.35 & 45.69 & 12.80 & 21.20 \\
\hline CLOSURE & ( $\%$ of Input): & 97.3 & 100.0 & 93.3 & 96.5 & 100.0 \\
\hline
\end{tabular}

\begin{tabular}{|c|c|c|c|c|c|c|}
\hline PROXIIIAT & ANALYSES & $\begin{array}{c}\text { Total } \\
\text { (\%) }\end{array}$ & $\begin{array}{l}V M \\
(\%)\end{array}$ & $\begin{array}{l}\text { FC } \\
(\%)\end{array}$ & $\begin{array}{l}\text { Ash } \\
(\%)\end{array}$ & $\begin{array}{c}\text { Moisture } \\
(\%)\end{array}$ \\
\hline IN : & Feed Coal & 100.0 & 39.0 & 35.8 & 97 & 15.5 \\
\hline OUT: & $\begin{array}{l}\text { Product } \\
\text { Volatiles } \\
\text { Ent. Solids } \\
\text { Moisture }\end{array}$ & $\begin{array}{l}100.0 \\
100.0 \\
100.0 \\
100.0\end{array}$ & $\begin{array}{r}34.8 \\
100.0 \\
43.3 \\
0.0\end{array}$ & $\begin{array}{r}51.2 \\
0.0 \\
40.5 \\
0.0\end{array}$ & $\begin{array}{r}13.9 \\
0.0 \\
15.6 \\
0.0\end{array}$ & $\begin{array}{r}0.1 \\
0.0 \\
0.6 \\
100.0\end{array}$ \\
\hline
\end{tabular}

EXPERIMENTAL YIELD SUMMARY

\begin{tabular}{|c|c|c|c|c|c|c|}
\hline YIELD & ( $\%$ of Input) & $\begin{array}{c}\text { Total } \\
(\%)\end{array}$ & $\begin{array}{l}V M \\
(\%)\end{array}$ & $\begin{array}{l}\text { FC } \\
(\%)\end{array}$ & $\begin{array}{l}\text { Ash } \\
(\%)\end{array}$ & $\begin{array}{c}\text { Moisture } \\
(\&)\end{array}$ \\
\hline \multirow[t]{3}{*}{ OUT : } & $\begin{array}{l}\text { Product } \\
\text { Vnlatiles } \\
\text { Ent. Solids } \\
\text { Moisture }\end{array}$ & $\begin{array}{r}60.3 \\
15.3 \\
6.3 \\
15.4\end{array}$ & $\begin{array}{r}53.8 \\
39.2 \\
7.0 \\
0.0\end{array}$ & $\begin{array}{r}86.2 \\
0.0 \\
7.1 \\
0.0\end{array}$ & $\begin{array}{r}86.3 \\
0.0 \\
10.1 \\
0.0\end{array}$ & $\begin{array}{r}0.4 \\
0.0 \\
0.2 \\
99.4\end{array}$ \\
\hline & I.OSSES (\%) & 2.7 & -0.0 & 6.7 & 3.5 & 0.0 \\
\hline & $(1 \mathrm{~b})$ & 3.75 & 0.00 & 3.28 & 0.47 & 0.00 \\
\hline
\end{tabular}


ATOMIC BALANCE FOR COAL DRYING EXPERIMENT: D-52 DAF

USIBELLI COAL

\begin{tabular}{|c|c|c|c|c|c|c|c|c|}
\hline MASS & $\begin{array}{c}\text { Total } \\
(1 b \text { daf })\end{array}$ & $\left(\begin{array}{ll}c & c \\
(1 b & d a f\end{array}\right)$ & $(1 \mathrm{~b}$ & $\begin{array}{l}\mathrm{H} \\
\mathrm{daf} \text { ) }\end{array}$ & $\left(\begin{array}{ll}N \\
\text { ( d b }\end{array}\right)$ & $(1 \mathrm{~b}$ & $\begin{array}{l}\text { S } \\
\text { daf) }\end{array}$ & (1b daf $)$ \\
\hline $\begin{array}{l}\text { IN: } \\
\text { Feed Coal } \\
\text { FG } \\
\text { N2 TRACER }\end{array}$ & $\begin{array}{r}102.32 \\
189.68 \\
18.97\end{array}$ & $\begin{array}{r}70.40 \\
51.73 \\
0.00\end{array}$ & & $\begin{array}{l}5.93 \\
0.00 \\
0.00\end{array}$ & $\begin{array}{r}0.61 \\
0.00 \\
18.97\end{array}$ & & $\begin{array}{l}0.20 \\
0.00 \\
0.00\end{array}$ & $\begin{array}{r}25.17 \\
137.95 \\
0.00\end{array}$ \\
\hline Total In: & 310.96 & 122.13 & & 5.93 & 19.58 & & 0.20 & 163.12 \\
\hline $\begin{array}{l}\text { OUT: } \\
\text { Product } \\
\text { Exit Gas } \\
\text { Ent. Sol. }\end{array}$ & $\begin{array}{r}70.88 \\
229.57 \\
7.22\end{array}$ & $\begin{array}{r}50.82 \\
57.62 \\
5.22\end{array}$ & & $\begin{array}{l}3.40 \\
0.46 \\
0.30\end{array}$ & $\begin{array}{r}0.64 \\
21.35 \\
0.09\end{array}$ & & $\begin{array}{l}0.18 \\
0.00 \\
0.01\end{array}$ & $\begin{array}{r}15.81 \\
150.14 \\
1.60\end{array}$ \\
\hline Total out: & 307.67 & 113.66 & & 4.16 & 22.08 & & 0.19 & 167.54 \\
\hline $\begin{array}{l}\text { CLOSURE: } \\
\text { is Input }\end{array}$ & 98.9 & 93.1 & & 70.1 & 112.8 & & 93.6 & 102.7 \\
\hline ULTIMATE ANALYSES & $\begin{array}{l}\text { Total } \\
(\% \text { daf })\end{array}$ & $(\%$ daf $)$ & $1 \%$ & $\begin{array}{l}\mathrm{H} \\
\mathrm{daf})\end{array}$ & $\left(\begin{array}{ll}\mathrm{N} \\
\text { daf })\end{array}\right.$ & $(.8$ & daf) & $(\%$ daf $)$ \\
\hline $\begin{array}{l}\text { IN: } \\
\text { Feed Coal } \\
\text { FG ( } \mathrm{CO} 2) \\
\text { FG (N2) }\end{array}$ & $\begin{array}{l}100.0 \\
100.0 \\
100.0\end{array}$ & $\begin{array}{r}68.8 \\
27.3 \\
0.0\end{array}$ & & $\begin{array}{l}5.8 \\
0.0 \\
0.0\end{array}$ & $\begin{array}{r}0.6 \\
0.0 \\
100.0\end{array}$ & & $\begin{array}{l}0.2 \\
0.0 \\
0.0\end{array}$ & $\begin{array}{r}24.6 \\
72.7 \\
0.0\end{array}$ \\
\hline $\begin{array}{l}\text { OUT: } \\
\text { Product } \\
\text { Exit Gas } \\
\text { Ent. Sol. }\end{array}$ & $\begin{array}{l}100.0 \\
100.0 \\
100.0\end{array}$ & $\begin{array}{l}71.7 \\
25.1 \\
72.3\end{array}$ & & $\begin{array}{l}4.8 \\
0.2 \\
4.1\end{array}$ & $\begin{array}{l}0.9 \\
9.3 \\
1.3\end{array}$ & & $\begin{array}{l}0.3 \\
0.0 \\
0.2\end{array}$ & $\begin{array}{l}22.3 \\
65.4 \\
22.1\end{array}$ \\
\hline
\end{tabular}


ENERGY BALANCE FOR COAL DRYING EXPERIMENT: D-52

USIBELLI COAL

Exp. Duration, hr:

13.0

\begin{tabular}{|c|c|c|c|c|}
\hline ENERGY & $\begin{array}{l}\text { Total } \\
\text { Energy } \\
\text { mbtu/hr }\end{array}$ & $\begin{array}{l}\text { Mass } \\
\text { Rate, } \\
\text { lb/hr }\end{array}$ & $\begin{array}{c}\text { Sensible + Latent } \\
\text { Heat } \\
\text { btu } / \mathrm{hr}\end{array}$ & $\begin{array}{l}\text { Heat Content } \\
\mathrm{mbtu} / \mathrm{hr}\end{array}$ \\
\hline \multicolumn{5}{|c|}{ IN : $\quad(T$ ref. $60 \mathrm{~F})$} \\
\hline $\begin{array}{l}\text { Feed Coal } \\
\text { FG (CO2) } \\
\text { Tracer (N2) } \\
\text { Electric Ht. Added }\end{array}$ & $\begin{array}{r}89.35 \\
5.93 \\
0.00 \\
2.86\end{array}$ & $\begin{array}{r}10.55 \\
14.63 \\
1.46\end{array}$ & $\begin{array}{r}0.0 \\
5926.6 \\
0.0 \\
2862.0\end{array}$ & $\begin{array}{r}89.35 \\
0.00 \\
0.00\end{array}$ \\
\hline Total In: & 98.14 & 26.64 & 8788.6 & 89.35 \\
\hline \multicolumn{5}{|c|}{ OUT: $\quad(\mathrm{T} \mathrm{ref.} 60 \mathrm{~F})$} \\
\hline Product & 66.70 & 6.36 & 1450.5 & 65.25 \\
\hline \multicolumn{5}{|l|}{ Exit Gas: } \\
\hline $\begin{array}{l}\text { Pyrol, Gas } \\
\text { FG (CO2) } \\
\text { TR (N2) } \\
\text { Steam }\end{array}$ & $\begin{array}{l}3.05 \\
2.77 \\
0.27 \\
2.31\end{array}$ & $\begin{array}{r}1.61 \\
14.63 \\
1.46 \\
1.62\end{array}$ & $\begin{array}{r}350.7 \\
2773.5 \\
267.3 \\
2308.9\end{array}$ & $\begin{array}{l}2.70 \\
0.00 \\
0.00 \\
0.00\end{array}$ \\
\hline Ent. Sol & 6.87 & 0.66 & 160.8 & 6.71 \\
\hline Total Out: & 81.97 & 26.35 & 7311.87 & 74.65 \\
\hline
\end{tabular}

$\begin{array}{lccc} & \text { Specific Heat } & \text { Higher Heating } \\ \text { THERMODYNAMIC } & \text { Temperature } & \text { Capacity } & \text { Value } \\ \text { DATA: } & \text { F } & \text { btu/lb F } & \text { btu/lb }\end{array}$

IN: $\quad(\mathrm{T}$ ref. $60 \mathrm{~F})$

$\begin{array}{lrrr}\text { Feed Coal } & 60 & 0.350 & 8470 \\ \text { FG (CO2) } & 1415 & 0.299 & 0 \\ \text { Tracer (N2) } & 60 & 0.249 & 0 \\ \text { OUT: (T ref. } 60 \mathrm{~F}) & & \\ \text { Product } & 712 & 0.350 & 10265 \\ \text { Exit Gas: } & & & 1673 \\ \text { Pyrol.Gas } & 752 & 0.314 & 0 \\ \text { FG (CO2) } & 752 & 0.274 & 0 \\ \text { Tacer (N2) } & 712 & 0.498 & 0 \\ \text { Steam } & 752 & 0.350 & 10100 \\ \text { Ent. Sol. } & 752 & & \end{array}$


MATERIAL BALANCE FOR COAL DRYING EXPERIMENT: D-53

\begin{tabular}{|c|c|c|c|c|c|c|}
\hline MASS & & $\begin{array}{l}\text { Total } \\
\text { (1b) }\end{array}$ & $\begin{array}{l}\mathrm{VM} \\
(\mathrm{lb})\end{array}$ & $\begin{array}{l}F C \\
(1 \mathrm{~b})\end{array}$ & $\begin{array}{l}\text { Ash } \\
(1 \mathrm{~b})\end{array}$ & $\begin{array}{c}\text { Moisture } \\
\text { (1b) }\end{array}$ \\
\hline IN : & Feed Coal & 131.72 & 46.36 & 51.50 & 6.72 & 27.13 \\
\hline \multirow[t]{2}{*}{ OUT: } & $\begin{array}{l}\text { Product } \\
\text { Volatiles } \\
\text { Ent. Solids } \\
\text { Moisture }\end{array}$ & $\begin{array}{l}69.60 \\
19.86 \\
11.40 \\
26.87\end{array}$ & $\begin{array}{r}21.65 \\
19.86 \\
4.86 \\
0.00\end{array}$ & $\begin{array}{r}41.90 \\
0.00 \\
5.64 \\
0.00\end{array}$ & $\begin{array}{l}5.78 \\
0.00 \\
0.84 \\
0.00\end{array}$ & $\begin{array}{r}0.21 \\
0.00 \\
0.06 \\
26.87\end{array}$ \\
\hline & Total out: & 127.73 & 46.36 & 47.54 & 6.62 & 27.13 \\
\hline CLOSURE & ( $\%$ of Input): & 97.0 & 100.0 & 92.3 & 98.6 & 100.0 \\
\hline
\end{tabular}

\begin{tabular}{|c|c|c|c|c|c|c|}
\hline PROXIMATE & E ANALYSES & $\begin{array}{c}\text { Total } \\
\text { (\%) }\end{array}$ & $\begin{array}{l}V M \\
(\%)\end{array}$ & $\begin{array}{l}F C \\
(8)\end{array}$ & $\begin{array}{l}\text { Ash } \\
\left(\psi_{2}\right)\end{array}$ & $\begin{array}{c}\text { Moisture } \\
(\%)\end{array}$ \\
\hline IN : & Feed Coal & 100.0 & 35.2 & 39.1 & 5.1 & 20.6 \\
\hline OUT : & $\begin{array}{l}\text { Product } \\
\text { Volatiles } \\
\text { Ent. Solids } \\
\text { Moisture }\end{array}$ & $\begin{array}{r}99.9 \\
100.0 \\
100.0 \\
100.0\end{array}$ & $\begin{array}{r}31.1 \\
100.0 \\
42.6 \\
0.0\end{array}$ & $\begin{array}{r}60.2 \\
0.0 \\
49.5 \\
0.0\end{array}$ & $\begin{array}{l}8.3 \\
0.0 \\
7.4 \\
0.0\end{array}$ & $\begin{array}{r}0.3 \\
0.0 \\
0.5 \\
100.0\end{array}$ \\
\hline
\end{tabular}

EXPERIMENTAL YIELD SUMMARY

\begin{tabular}{|c|c|c|c|c|c|c|}
\hline YIELD & ( $\%$ of Input) & $\begin{array}{c}\text { Totai } \\
(\%)\end{array}$ & $\begin{array}{l}V M \\
(\%)\end{array}$ & $\begin{array}{l}F C \\
(\%)\end{array}$ & $\begin{array}{l}\text { Ash } \\
(\%)\end{array}$ & $\begin{array}{c}\text { Moisture } \\
(\%)\end{array}$ \\
\hline \multirow[t]{3}{*}{ OUT: } & $\begin{array}{l}\text { Product } \\
\text { Volatiles } \\
\text { Ent. Solids } \\
\text { Moisture }\end{array}$ & $\begin{array}{r}52.8 \\
15.1 \\
9.7 \\
20.4\end{array}$ & $\begin{array}{r}46.7 \\
42.8 \\
10.5 \\
0.0\end{array}$ & $\begin{array}{r}81.4 \\
0.0 \\
11.0 \\
0.0\end{array}$ & $\begin{array}{r}36.0 \\
0.0 \\
12.6 \\
0.0\end{array}$ & $\begin{array}{r}0.8 \\
0.0 \\
0.2 \\
99.0\end{array}$ \\
\hline & \multirow[t]{2}{*}{ LOSSES (\%) } & 3.0 & 0.0 & 7.7 & 1.4 & 0.0 \\
\hline & & 3.99 & 0.00 & 3.96 & 0.10 & 0.00 \\
\hline
\end{tabular}


ATOMIC BALANEE FOR COAL DRYING EXPERT.MENT: D-53 DAF

EAGLE BUTTE COAL

\begin{tabular}{|c|c|c|c|c|c|c|}
\hline MASS & $\begin{array}{l}\text { Total } \\
(1 b \text { daf })\end{array}$ & $\begin{array}{ll}C \\
\text { ib daf }\end{array}$ & $\begin{array}{l}\mathrm{H} \\
(1 \mathrm{~b} d \mathrm{~d} f,\end{array}$ & $(1 \mathrm{~b} d \mathrm{daf})$ & $\left(\begin{array}{ll} & S \\
(1 b & d a f\end{array}\right)$ & 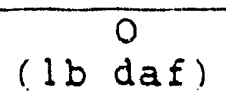 \\
\hline $\begin{array}{l}\text { IN: } \\
\text { Feed Coal } \\
\text { FG } \\
\text { it TRACER }\end{array}$ & $\begin{array}{r}94.86 \\
186.91 \\
19.63\end{array}$ & $\begin{array}{r}68.39 \\
50.98 \\
0.00\end{array}$ & $\begin{array}{l}5.12 \\
0.00 \\
0.00\end{array}$ & $\begin{array}{r}0.85 \\
0.00 \\
19.63\end{array}$ & $\begin{array}{l}0.57 \\
0.00 \\
0.00\end{array}$ & $\begin{array}{r}19.92 \\
135.94 \\
0.00\end{array}$ \\
\hline Total In: & 301.40 & 119.37 & 5.12 & 20.48 & 0.57 & 155.86 \\
\hline $\begin{array}{l}\text { OUT: } \\
\text { Product } \\
\text { Exit Gas } \\
\text { Ent. Sol. }\end{array}$ & $\begin{array}{r}63.55 \\
226.40 \\
10.50\end{array}$ & $\begin{array}{r}48.36 \\
57.05 \\
7.76\end{array}$ & $\begin{array}{l}2.41 \\
0.45 \\
0.50\end{array}$ & $\begin{array}{r}0.76 \\
21.06 \\
0.12\end{array}$ & $\begin{array}{l}0.52 \\
0.00 \\
0.06\end{array}$ & $\begin{array}{r}11.50 \\
147.84 \\
2.06\end{array}$ \\
\hline Total out: & 300.45 & 113.17 & 3.37 & 21.93 & 0.57 & 161.40 \\
\hline $\begin{array}{l}\text { CLOSURE: } \\
\% \text { Input }\end{array}$ & 99.7 & 94.8 & 65.8 & 107.1 & 100.4 & 103.6 \\
\hline
\end{tabular}

\begin{tabular}{|c|c|c|c|c|c|c|c|}
\hline ULTIMATE ANALYSES & $\begin{array}{l}\text { Total } \\
\text { (\% daf) }\end{array}$ & $(\%$ & $\begin{array}{l}\text { C } \\
\text { daf) }\end{array}$ & $\begin{array}{l}\mathrm{H} \\
(q \mathrm{daf})\end{array}$ & $\left(\begin{array}{ll}N \\
\text { daf })\end{array}\right.$ & $(\%$ daf $)$ & (\% daf) \\
\hline $\begin{array}{l}\text { IN: } \\
\text { Feed Coal } \\
\text { FG (CO2) } \\
\text { FG (N2) }\end{array}$ & $\begin{array}{l}100.0 \\
100.0 \\
100.0\end{array}$ & & $\begin{array}{r}72.1 \\
27.3 \\
0.0\end{array}$ & $\begin{array}{l}5.4 \\
0.0 \\
0.0\end{array}$ & $\begin{array}{r}0.9 \\
0.0 \\
100.0\end{array}$ & $\begin{array}{l}0.6 \\
0.0 \\
0.0\end{array}$ & $\begin{array}{r}21.0 \\
72.7 \\
0.0\end{array}$ \\
\hline $\begin{array}{l}\text { OUT: } \\
\text { Produat } \\
\text { Exit Gas } \\
\text { Ent. Sol. }\end{array}$ & $\begin{array}{l}100.0 \\
100.0 \\
100.0\end{array}$ & & $\begin{array}{l}76.1 \\
25.2 \\
73.9\end{array}$ & $\begin{array}{l}3.8 \\
0.2 \\
4.8\end{array}$ & $\begin{array}{l}1.2 \\
9.3 \\
1.1\end{array}$ & $\begin{array}{l}0.8 \\
0.0 \\
0.6\end{array}$ & $\begin{array}{l}18.1 \\
65.3 \\
19.6\end{array}$ \\
\hline
\end{tabular}


ENERGY BALANCE FOR COAL DRYING EXPERIMENT: D-53

EAGLE BUTTE COAL

Exp. Duration, hr:

13.4

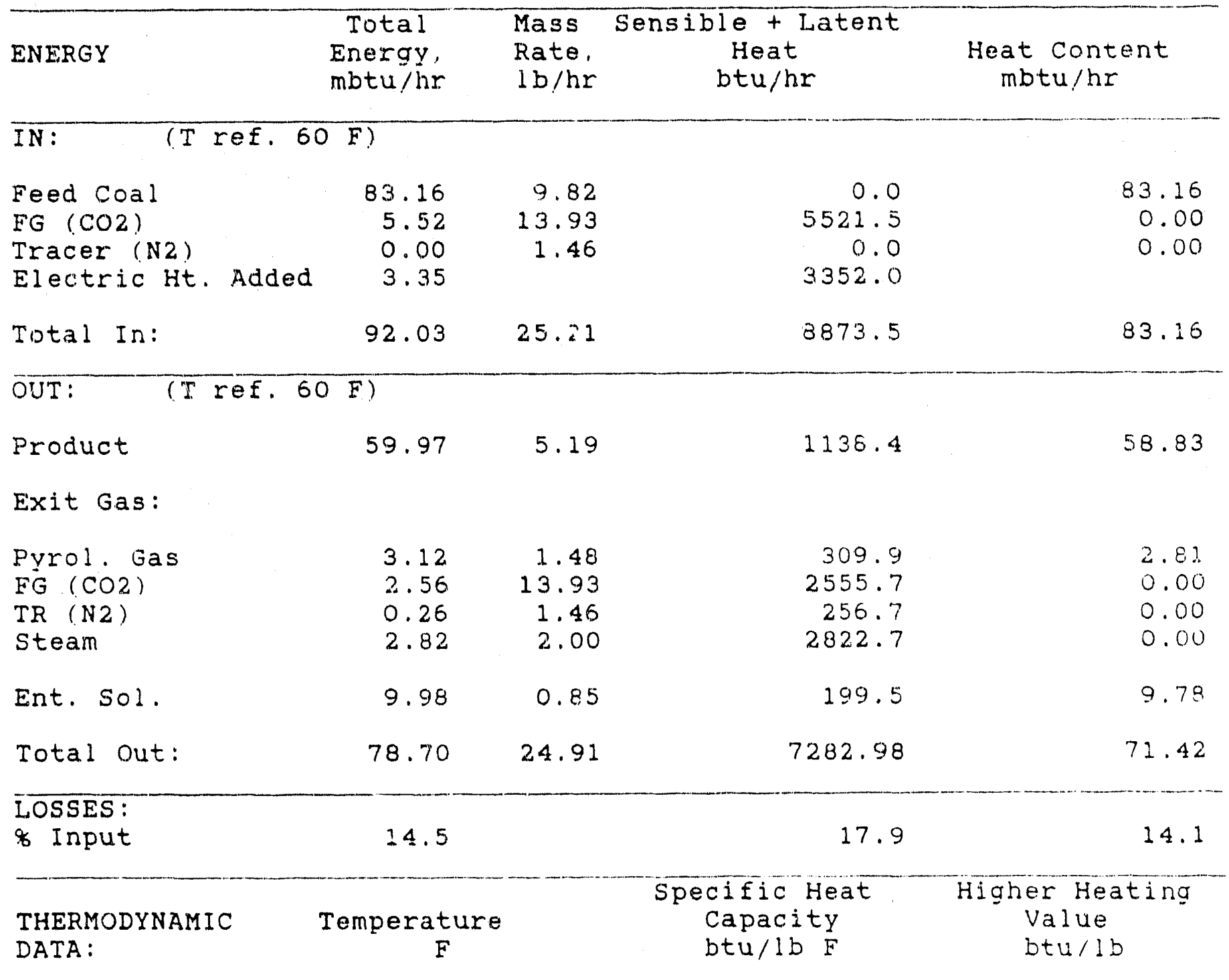

IN: (T ref. $50 \mathrm{~F})$

Feed Coal

FG ( $\mathrm{CO} 2)$

Tracer (N2)
60

1390

60
0.350

0.298

0.249
8470

0

o

OUT: (T ref. $60 \mathrm{~F}$ )

Product

087

0.350

11340

Exit Gas:

Pyrol. Gas

FG ( $\mathrm{CO} 2)$

Tacer (N2)

Steam

0.312

0.273

731

0.262

731

0.496

Ent. Sol.

731

0.350 
APPENDIX B 


\title{
DEVELOPMENT OF AN ADVANCED PROCESS FOR DRYING COAL IN AN INCLINED FLUIDIZED BED
}

Task 4. Product Characterization and Testing

Final Report

\author{
By \\ Mark H. Berggren \\ Mahesh C. Jha \\ AMAX. Research \& Development Center \\ 5950 Mclntyre Street \\ Golden, Colorado 80403-7499
}

\author{
Prepared for \\ Western Research Institute \\ P. O. Box 3395 \\ $365 \mathrm{~N}$. 9th Street \\ Laramie, Wyoming 82071
}

DOE Contract No. DE-AC22-88PC88886

WRI Contract No. 893011

January 24,1990 


\section{LEGAL NOTICE}

THIS REPORT WAS PREPARED BY AMAX RESEARCH \& DEVELOPMENT CENTER, AS AN ACCOUNT OF WORK SPONSORED BY WESTERN RESEARCH INSTITUTE.

NEITHER AMAX RESEARCH \& DEVELOPMENT CENTER NOR ANY PERSON ACTING ON ITS BEHALF:

(A) MAKES ANY WARRANTY, EXPRESSED OR IMPLIED, WITH RESPECT TO THE USE OF ANY INFORMATION, APPARATUS, METHOD, OR PROCESS DISCLOSED IN THIS REPORT OR THAT SUCH USE MAY NOT INFRINGE PRIVATELY OWNED RIGHTS; OR

(B) ASSUMES ANY LIABILITIES WITH RESPECT TO THE USE OF, OR FOR THE DAMAGES RESULTING FROM THE USE OF, ANY INFORMATION, APPARATUS, METHOD, OR PROCESS DISCLOSED IN THIS REPORT. 


\begin{abstract}
« program to develop an inclined fluidized-bed (IFB) coal dryer for removal of internal moisture was conducted at Western Research Institute (WRI) under U. S. Department of Energy sponsorship. High-moisture subbituminous coals from Wyoming (Eagle Butte) and Alaska (Usibelli) were investigatea. AMAX R\&D characturized the feed coals and dried products under a subcontract to W/RI.

Product characterizations demonstrated that the inclined fluidized-bed drying process can successfully produce coals cointaining less than 1 percent moisture. Moisture reabsorption decreased as a function of increasirig IFB drying temperature. Dried coal products contained very low dust levels compared tu the feed coals. The Usibelli coal was found to be generally less dusty than the Eagle Butte coal. Spontaneous heating characteristics of the feed and dried coals showed that coals dried at the highest temperatures were most susceptible to spontaneous heating.
\end{abstract}




\section{TABLE OF CONTENTS}

Page

INTRODUCTION AND OBJECTIVES $\ldots \ldots \ldots \ldots \ldots \ldots \ldots \ldots$

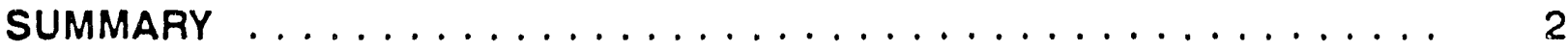

RECOMMENDATIONS $\ldots \ldots \ldots \ldots \ldots \ldots \ldots \ldots \ldots \ldots \ldots \ldots \ldots \ldots$

TECHNICAL APPROACH $\ldots \ldots \ldots \ldots \ldots \ldots \ldots \ldots \ldots \ldots$

MOISTURE REABSORPTION CHARACTERISTICS ..........4 4

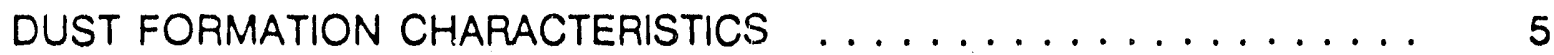

SPONTANEOUS HEATING CHARACTEHISTICS $\ldots \ldots \ldots \ldots \ldots \ldots .5$

EFFECT OF SURFACE TREATMENTS $\ldots \ldots \ldots \ldots \ldots \ldots \ldots$

OTHER CHARACTERIZATIONS $\ldots \ldots \ldots \ldots \ldots \ldots \ldots \ldots . \ldots$

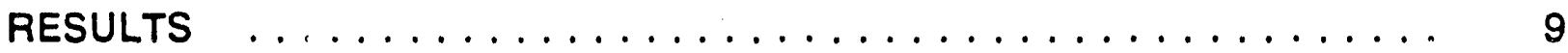

MOISTURE REABSORPTION $\ldots \ldots \ldots \ldots \ldots \ldots \ldots \ldots$

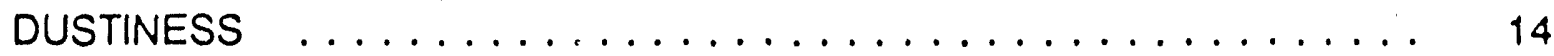

SPONTANEOUS HEATING $\ldots \ldots \ldots \ldots \ldots \ldots \ldots \ldots \ldots$

SURFACE AREA AND PARTICLE DENSITY ANALYSES $\ldots \ldots \ldots \ldots 22$

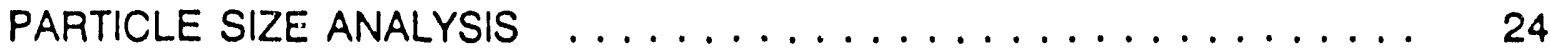

EFFECT OF SURFACE TREATMENTS $\ldots \ldots \ldots \ldots \ldots \ldots \ldots$

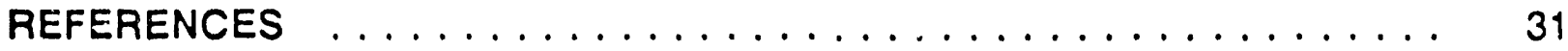




\section{LIST OF TABLES}

Page

Table 1. Reabsorption of Moisture by Eagle Butte Coal $\ldots \ldots \ldots . \ldots 9$

Table 2. Reabsorption of Moisture by Usibelli Coal $\ldots \ldots \ldots$. . . . . . 10

Table 3. Reabsorption of Moisture by Eagle Butte and Usibelli

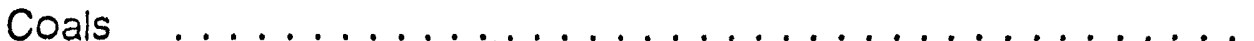

Table 4. Moisture Reabsorption Characteristics of Oven-Dried

Eagle Butte and Usibelli Coals ................. 14

Table 5. Moisture Reabsorption Characteristics of Compressed

Eagle Butte and Usibelli Dried Coal Pellets ............. 14

Table 6. Opacity Meter Measurements of Eagle Butte Coal Feeds

and Dried Products . . . . . . . . . . . . . . . . . . 17

Table 7. Opacity Meter Measurements of Usibelli Coal Feeds and Dried Products . . . . . . . . . . . . . . . . . . . 17

Table 8. Self-Heating Characteristics of Eagle Butte Coals $\ldots . \ldots . \ldots 21$

Table 9. Self-Heating Characteristics of Usibelli Coals $\ldots \ldots \ldots \ldots 21$

Table 10. Eagle Butte and Usibelli Feed and Dried Coal Surface Areas and Particle Densities ................ 23

Table 11. Effect of Drying Conditions on Surface Area and SelfHeating Characteristics .................... 25

Table 12. Particle Size Analysis of IFB Dryer Samples $\ldots \ldots \ldots 26$

Table 13. Particle Size Analysis of IFB Dryer Samples . . . . . . . . . 27

Table 14. Effect of Spraying Coal-Derived Pitch/Tar on Coal

Dustiness ........................... 29

Table 15. Effect of Spraying Coal-Derived Pitch/Tar on Moisture Reabsorption ... . . . . . . . . . . . . . . . 29

Table 16. Effect of Spraying Petroleum-Derived Liquid on Coal Dustiness .......................... 
LIST OF FIGURES

Page

Figure 1. Optic al static dust tester.

Figure 2. Self-heating apparatus.

Figure 3. Equilibrium moisture as a function of drying temperature. . . . .

Figure 4. Eagle Butte coal dust characteristics. .............

Figure 5. Usibelli coal dust characteristics.

Figure 6. Self-heating characteristics of Eagle Butte coal. . . . . . . . .

Figure 7. Self-heating characteristics of Usibelli coal. $\ldots \ldots \ldots \ldots 20$
6

7

11

15

16

19

iii

198 


\section{INTRODUCTION AND OBJECTIVES}

Subbituminous coals can be more widely utilized if internal moisture is removed in order to increase the heating value. Removal of moisture can allow lower-rank coals to be substituted for higher-rank coals in many combustors, allowing utilities and industry to use low-sulfur subbituminous coals without boiler derating. Removal of moisture can also reduce transportation costs.

However, thermal drying of subbituminous coals can lead to problems associated with moisture reabsorption, dust formation, and spontaneous heating. Controlled thermal drying of coal using the inclined fluidized-bed (IFB) process under development by WRI can help to overcome these problems. Mild pyrolysis conditions utilized during the drying step mobilize tars which can protect the dried coal surfaces and pores.

Prevention of moisture reabsorption iollowing drying is important for maintaining the greater heating value associated with dried coal and for preventing temperature increases which are often due to the heat of wetting associated with moisture reabsorption.

Thermally dried coal samples which have not been stabilized against dust formation may be unacceptable for use from the viewpoint of conventional utility and industrial boiler operators. The loss of cleaned coal product and the potential explosion hazards and health effects of very fine coal are of concern for both producers and users.

Perhaps of greatest concern in thie handling of processed coal is the potential for spontaneous combustion. As stated above, the initial heat of wetting leads to temperature increases which can then increase the rate of oxidation of the coal. Under some conditions, the heat generated by oxidation is greater than the heat removed by any gas flow through the coal and combustion starts.

The effectiveness of the inclined fluidized-bed drying process was determined by measuring the moisture reabsorption, dust formation, spontaneous heating, and other characteristics of coals dried under different conditions.

The specific objective of AMAX R\&D's involvement was to determine the characteristics of the dried coals produced at WRI. The effect of drying conditions on product characteristics was also evaluated in order to help establish optimum process conditions. 


\section{SUMMARY}

Feeds and selected test products from the IFB coal drying program at WRI were characterized at AMAX R\&D for moisture reabsorption, dustiness, spontaneous heating, and other properties. Subbituminous Eagle Butte (Wyoming) coal and Usibelli (Alaska) coals were utilized for the project.

Product characterizations demonstrated that the inclined fluidized-bed process can successfully produce coals containing less than 1 percent moisturi. The equilibrium moisture of the dried coals was reduced significantly during the process to levels as low as about one-half of that contained in the feed coals. Equilibrium moisture contents of the IFB-dried Eagle Butte and Usibelli coals were less than those for the same coals dried at lower temperatures in air. Reabsorption of moisture to levels well under 10 percent was observed in IFB-dried samples subjected to humidity conditions typical of those in many parts of the United States. The level of moisture reabsorption decreased as a function of increasing IFB drying temperature and was not a function of the coal type. Compressed dry coal pellets prepared at WRI exhibited a lower amount of moisture reabsorption compared to the dry coal powders from which they were prepared.

Dried coal products contained very low dust levels compared to the feed coals. The Usibelli coal was found to be generally less dusty than the Eagle Butte coal. Based on size analyses and material balance data, only a small reduction in average particle size occurred during IFB drying.

Spontaneous heating characteristics of the feed and dried coals were evaluated to determine the effect of process conditions. In general, higher IFB drying temperatures led to greater spontaneous heating rates. 


\section{RECOMMENDATIONS}

The inclined fluidized-bed process has been derionstrated to be effective for drying of fine coal. Additional research and development work is recommended in the following areas.

- Scale-up of the system (greater coal throughput) to better define the process parameters for a commercial plant.

- Drying of coarser particles and investigation of the effects of coarser particles on throughput, product moisture content, dustiness, and spontaneous heating.

- Treatments such as introduction of air during the later stages of cooling as an effort to further stabilize the dried coal against spontaneous heating. 


\section{TECLIINICAL APIROACH}

Samples of feed coals and dried products from the WRI facility in Laramie were forwarded to AMAX R\&D for characterization of moisture reabsorption, dust formation, spontaneous heating tendencies, and other properties. Samples were sealed in plastic bags and exposed to air only as necessary to conduct the chararterizations. The characterizations centered on the longer-duration drying tests (about 12 hours), although many analyses were conducted using samples taken from shorter-duration tests. The following paragraphs briefly summarize the techniques used for the characterizations.

Procedures for determination of moisture content and reabsorption, dustine:ss, spontaneous heating tendencies, and other properties have been developed at AMAY. R\&D during previous research sponsored by AMAX Coal Company. Facilities for applying surface treatments to raw and processed coal fines have also been used for other research programs. The available facilities and test procedures were tailored for the types of coals examined duririg this research program.

\section{MOISTURE REABSORPTION CHARACTERISTICS}

A technique was developed at AMAX R\&D to measure moisture absorption characteristics of as-mined and thermally-dried coals. The procedure utilizes a controlled temperature/humidity chamber which is normally operated under conditions similar to those used for determination of the equilibrium moisture content of coal $\left(30^{\circ} \mathrm{C}\right.$ and 95 to 97 percent relative humidity). Selected samples were subjected to lower levels of humidity to more accurately simulate conditions likeiy to be encountered during transportation.

A controlled environment chamber (Associated Environmental Systems Model BHK-4103) was set to operate under the desired humidity and temperature conditions. The chamber utilizes heating, cooling, humidification, and dehumidification systems for control of environmental conditions.

Two types of measurements were typically made. In one case, coals were first immersed in water to fully saturate the samples prior to introduction into the controlled environment chamber (equilibrium moisture determination). In the other case, the coals were introduced as-is into the controlled environment chamber (moisture reabsorption determination). These two techniques provided information on moisture equilibration when approaching from dry and moist sample conditions.

Coal samples were introduced into clean, desiccated, tared glass weighing dishes which were then fitted with ground glass covers to prevent loss or introduction of moisture. The coal samples were weighed in the dishes with covers and then placed into the controlled environment chamber after removing the covers. 
The coal samples were exposed to the high humidity conditions until equilibrium was reached, which typically requires about 5 days. The weighing dish covers were immediately placed onto the dishes when removed from the environmental chamber and weighed after reaching room temperature. The amount of moisture increase was then determined. This technique allowed for the determination of equilibrium and moisture reabsorptinn characteristics using the feed and product samples.

\section{DUST FORMATION CHARACTERISTICS:}

Measurements of the relative amount of dust produced by various coal samples can be used to characterize the feed and dried coals and to determine surface treatment requirements. AMAX R\&D USES an opacity meter to cletermine the relative concentrations of fine coal dust which remain airborne as a function of time.

Figure 1 shows a diagram of the optical static dust tester which was fabricated at AMAX R\&D on the basis of work performed at Dow Chemical.' The unit consists of a 4-inch diameter, 30-inch tall stainless steel pipe into which a measured amount of material to be tested is introduced. A helium-neon laser provides a light source. The laser beam traverses the diameter of the pipe at a location near the bottom. A photo-detector is utilized to measure the transmittance of the laser light at 632.8 nanometers while the dust settles. A strip chart recorder automatically registers the transmittance as a function of time. A low flow of gas is used to purge the light path in order to prevent dust accumulation on the chamber windows. A sample size of 200 grams of coal is typically used. Greater values of light transmission indicate lower levels of dustiness. Although a continuous measurement of light transmission as a function of time was recorded, the degree of light transmission at some fixed time interval was typically used as a relative measure of dustiness.

\section{SPONTANEOUS HEATING CHARACTERISTICS}

An adiabatic system in which heat generated during absorption of moisture and oxidation of coal is not transferred to the surroundings is preferred for accurate modeling of self-heating characteristics and the kinetics of spontaneous combustion. ${ }^{2}$ An apparatus similar to that used by Guin et al. ${ }^{3}$ and shown in Figure 2 provided temperature data as a function of time during exposure to oxygen saturated with water vapor. In this unit, the coal is contained in Dewar flasks which are preheated to the desired starting temperature of $70^{\circ} \mathrm{C}$. The heat generated by absorption of moisture and coal oxidation was largely contained in the insulated flasks. The surrounding environment was not controlled to follow the temperature of the coal sample as is done in some cases.

Spontaneous heating test conditions were selected to emphasize the differences between the coal samples. Moisture-saturated oxygen provides a large driving force for self heating and was used for all of the tests. 


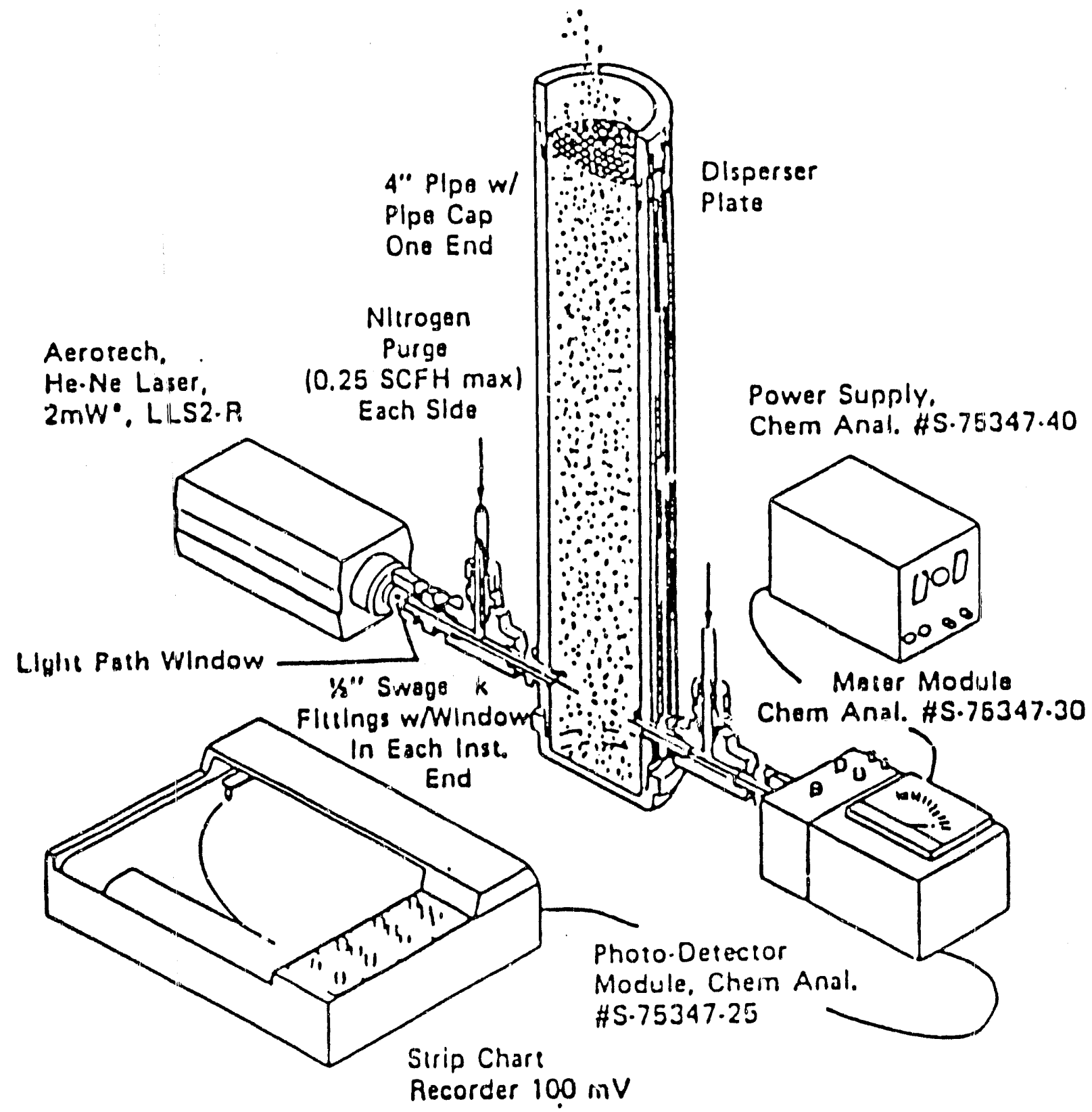

Figure 1. Optical static dust tester.' 

A. Thermocouple
B. Thermometer
I. Rubber Stopper
J. Stand
C. Temperature Display
K. Gas $\left(\mathrm{O}_{2}, \mathrm{~N}_{2}\right)$ Tanks
D. Temperature Recorder
E. Coal Sample
L.. Pressure Gauge
F. Dewar
M. Exhaust
G. Water Flask
N. Flow Meter
H. Gas Dispersion Tube
O. Screen

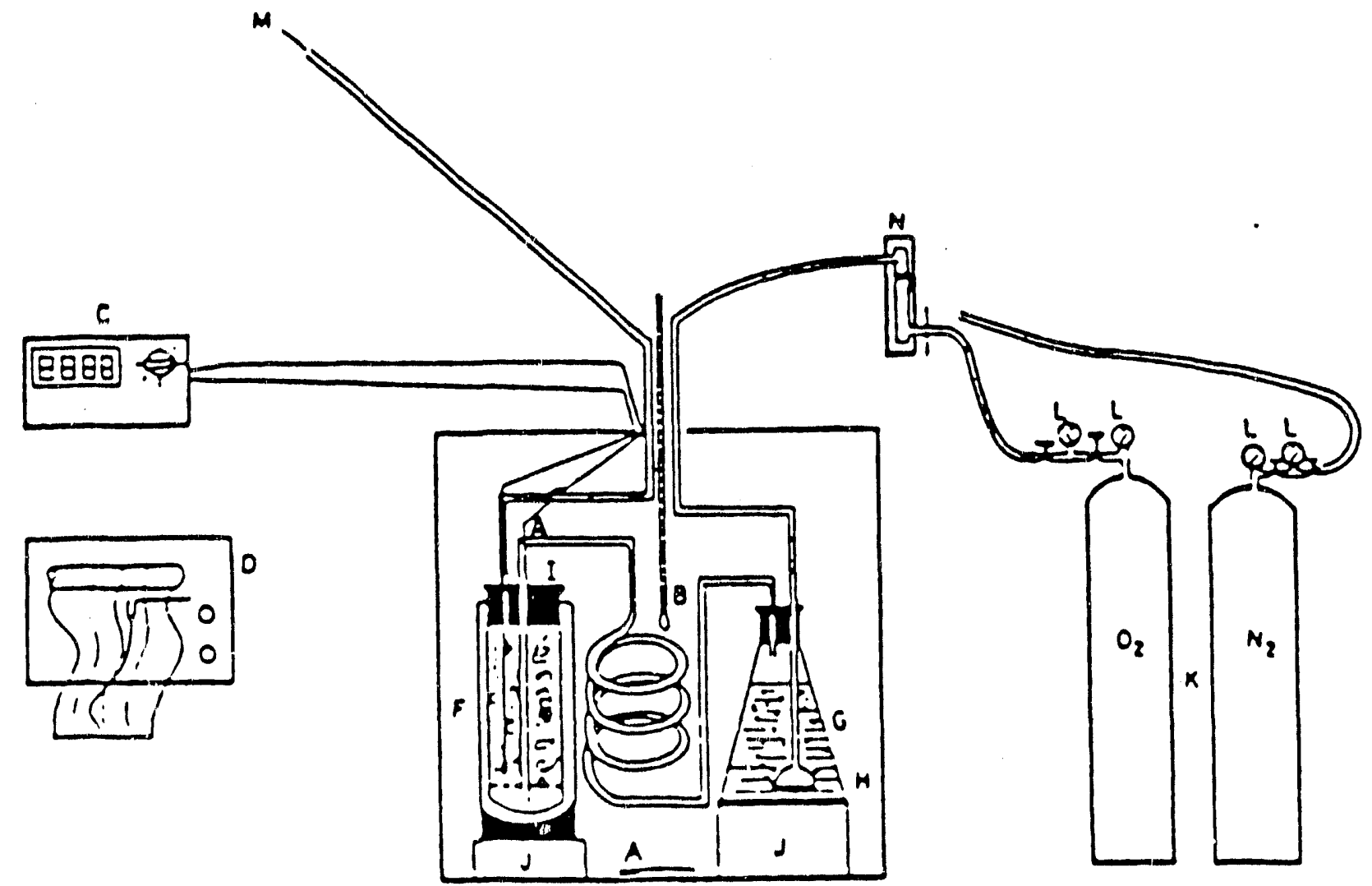

Figure 2. Self-heating apparatus. ${ }^{3}$ 


\section{EFFECT OF SURFACE TREATMENTS}

The effectiveness of the inclined fluidized-bed drying technique was further evaluated by determining the effect of surface treatments. Work performed by others using established dust and moisture control agents provided some background for the treatments. ${ }^{46}$

Coal- and petroleum-derived liquids were utilized for surface treatrients. A mrodified disk pelletizer was used during the application of surface coatings. A 20inch-diameter disk pelletizer was equipped with baffles to tumble the dried coal while a heated, high-pressure spray of oil or tar was applied. The modified pelletizing apparatus was configured in a manner which provided for continuous exposure of the coal fines to the treatment spray while minimizing actual pelletization.

A Parr stainless steel autoclave was used as a pressure vessel from which the heated oil or tar was sprayed. An inert gas overpressure was applied to the autoclave and a flexible, heat-traced line from the autoclave delivered the fluid to a spray nozzle. Past experience has shown that for this scale of application, a hydraulic spray is superior to other types of sprayers which require air or other gases for atomization of the treatment compound. Air atomization results in substantial loss of fines from the treatment chamber due to displacement of large volumes of air by the atomizing gas.

\section{OTHER CHARACTERIZATIONS}

Other product characterizations consisted of particle size, particle density, and surface area measurements. Standard sieve analyses and subsieve analyses using a Micromeritics SediGraph were pe formed on selected samples to determine the degree of particle deçradation or agglomeration which occurred during inclined fluidized-bed drying. Particle density was determined by displacement of kerosene. Standard BET surface area analyses were also performed on selected samples to determine the effects of temperature and other process conditions on the dried coal characteristics. 


\section{RESULTS}

The following sections describe the results obtained from characterization of the Eagle Butte and Usibelli coal feeds and products.

\section{MOISTURE REABSORPTION}

The Eagle Butte and Usibelli coal feeds and selected test products were subjected to moisture reabsorption tests, as shown by the results in Tables 1 and 2 . A significant reduction in equilibrium moisture occurred following inclined fluidizedbed drying of these samples. The dried coals reabsorbed roughly the same amount of moisture regardless of whether or not they were first immersed in deionized water (moisture reabsorption versus equilibrium moisture determination procedures).

Table 1. Reabsorption of Moisture by Eagle Butte coal

\begin{tabular}{|c|c|c|c|c|}
\hline \multirow[b]{2}{*}{ Sample } & $\begin{array}{c}\text { Average } \\
\text { Dryer }\end{array}$ & \multicolumn{3}{|c|}{ Moisture content, weight \& } \\
\hline & $\begin{array}{c}\text { Temperature, } \\
{ }_{0} \mathrm{~F}\end{array}$ & $\begin{array}{c}\text { As- } \\
\text { Received }\end{array}$ & $\begin{array}{c}\text { Moisture } \\
\text { Reabsorption }\end{array}$ & $\begin{array}{l}\text { Equilibrium } \\
\text { Moisture }\end{array}$ \\
\hline EB Feed & - & 28.1 & 27.3 & 26.9 \\
\hline D-39 Feed & -- & 19.7 & 21.7 & 26.1 \\
\hline$D-45$ Feed & -- & 26.8 & 26.5 & 28.2 \\
\hline$D-53$ Feed & -- & 16.2 & 19.4 & 23.5 \\
\hline$D-2$ & 586 & 2.6 & 13.8 & 12.8 \\
\hline$D-10$ & 591 & 0.3 & 13.9 & 13.9 \\
\hline$D-14$ & 690 & 0.5 & 12.8 & 12.3 \\
\hline$D-30$ & 531 & 1.9 & 16.8 & 16.0 \\
\hline$D-31$ & 695 & 0.6 & 13.9 & 13.2 \\
\hline$D-37$ & 684 & 0.9 & 14.4 & 12.5 \\
\hline$D-39$ & 611 & 0.8 & 14.6 & 13.4 \\
\hline$D-41$ & 603 & 0.7 & 14.9 & 15.9 \\
\hline$D-45$ & 682 & 1.0 & 13.9 & 13.4 \\
\hline$D-47$ & 645 & 0.7 & 14.2 & 14.2 \\
\hline$D-49$ & 375 & 0.4 & 18.6 & 19.9 \\
\hline$D-51$ & 589 & 1.0 & 15.6 & 14.1 \\
\hline$D-53$ & 731 & 0.6 & 14.0 & 12.2 \\
\hline
\end{tabular}

- Reabsorption of moisture upon exposure of the as-is sample

- to conditions of $\approx 95 q$ relative humidity $/ 30^{\circ} \mathrm{C}$ for 5 days. Reabsorption of moisture in samples which were first immersed in deionized water and then exposed to conditions of $\approx 95 \%$ relative humidity $/ 30^{\circ} \mathrm{C}$ for 5 days. 
Table 2. Reabsorption of Moisture by Usibelli coal

\begin{tabular}{|c|c|c|c|c|}
\hline \multirow[b]{2}{*}{ Sample } & $\begin{array}{c}\text { Average } \\
\text { Dryer }\end{array}$ & \multicolumn{3}{|c|}{ Moisture content, weight \& } \\
\hline & $\frac{{ }_{\mathrm{O}}^{\mathrm{F}}}{\text { Temperature, }}$ & $\begin{array}{c}\text { As- } \\
\text { Received }\end{array}$ & $\begin{array}{c}\text { Moisture } \\
\text { Reabsorption } \\
\end{array}$ & $\begin{array}{l}\text { Equilibrium } \\
\text { Moisture }\end{array}$ \\
\hline USI Feed & -- & 20.3 & 21.1 & 21.4 \\
\hline$D-38$ Feed & -- & 14.3 & 17.7 & 20.4 \\
\hline D-44 Feed & -- & 15.9 & 19.1 & 21.4 \\
\hline$D-52$ Feed & -- & 12.8 & 16.1 & 20.4 \\
\hline$D-17$ & 591 & 0.6 & 14.0 & 13.9 \\
\hline$D-22$ & 675 & 0.3 & 13.3 & 12.9 \\
\hline$D-29$ & 494 & 1.1 & 14.7 & 15.9 \\
\hline$D-32$ & 705 & 0.3 & 14.6 & 13.6 \\
\hline$D-35$ & 611 & 0.7 & 15.3 & 14.4 \\
\hline$D-36$ & 664 & 0.8 & 13.7 & 13.8 \\
\hline$D-38$ & 631 & 0.9 & 15.0 & 14.3 \\
\hline$D-43$ & 653 & 0.4 & 14.8 & 14.5 \\
\hline$D-46$ & 648 & 0.5 & 14.5 & 14.1 \\
\hline$D-48$ & 364 & 0.3 & 18.8 & 19.6 \\
\hline$D-50$ & 594 & 0.6 & 15.9 & 14.4 \\
\hline$D-52$ & 752 & 0.6 & 15.0 & 13.3 \\
\hline
\end{tabular}

- Reabsorption of moisture upon exposure of the as-is sample

b to conditions of $\approx 95 \%$ relative humidity $/ 30^{\circ} \mathrm{C}$ for 5 days.

Reabsorption of moisture in samples which were first

immersed in deionized water and then exposed to conditions of $\approx 95 \%$ relative humidity $/ 30^{\circ} \mathrm{C}$ for 5 days.

The different dryer feed samples obtained during the program were analyzed for moisture reabsorption, as shown in Tables 1 and 2. Moisture ieabsorption decreased somewhat as a function of the moisture content of the feeds. Some variation of the feed moisture contents probably existed as a result of exposure to carbon dioxide at WRI to remove surface moisture to improve feeding.

The moisture reabsorption is a function of the drying temperature as evidenced by greater equilibrium moisture values for samples dried at the lower test temperatures. For example, Eagle Butte and Usibelli coals which were dried at relatively low temperatures (Samples D.49 and D-48) exhibited the greatest values of moisture reabsorption and equilitrium moisture. The level of moisture reabsorption does not appear to be a strong function of coal type. Figure 3 shows equilibrium moisture content as a function of average drying temperature for both the Eagle Butte and Usibelii coals. 


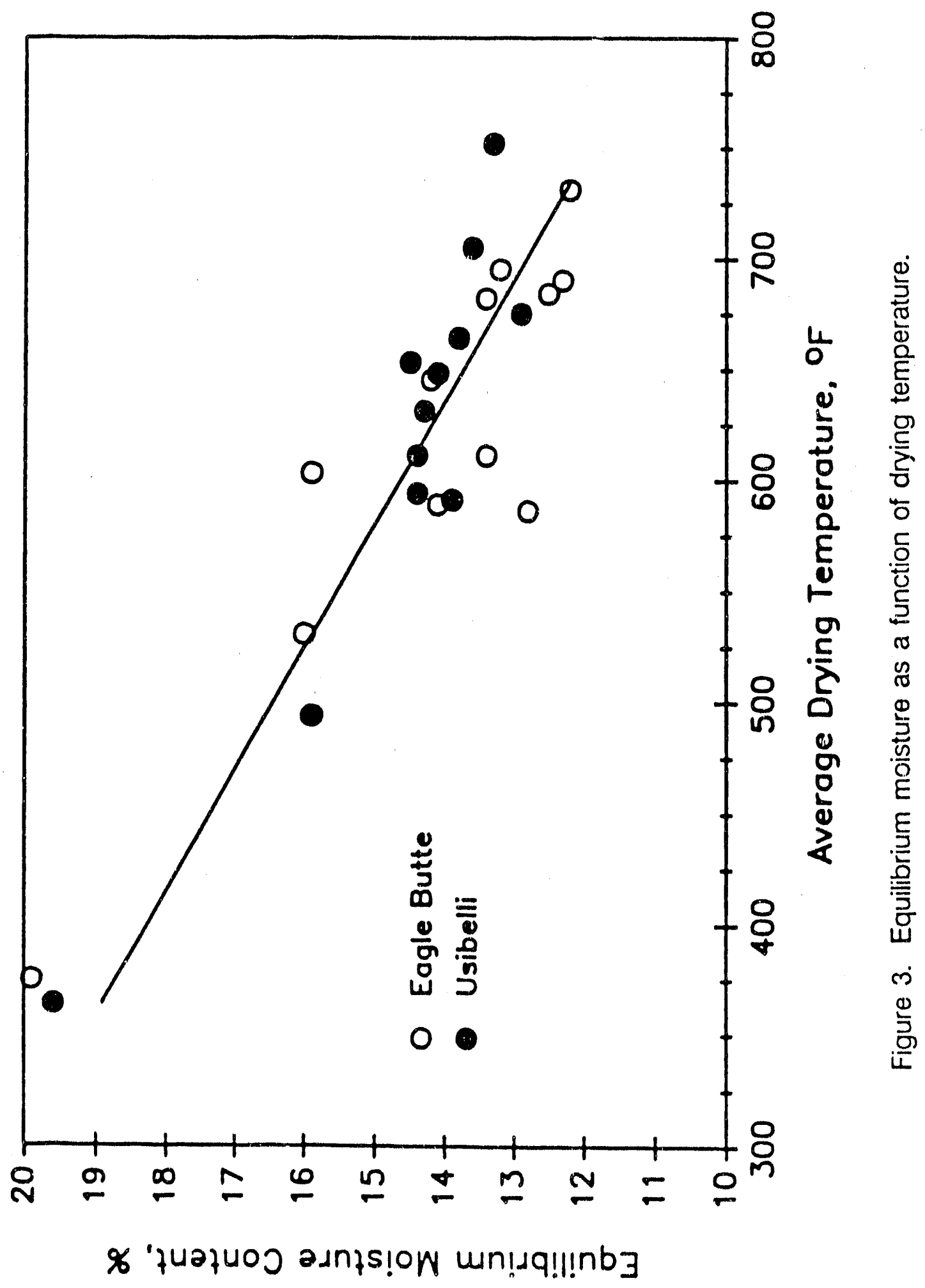


Additional moisture reabsorption tests were conducted using conditions of lower relative humidity more representative of environments which would be encountered during storage and transportation. Average values near 50 percent relative humidity are typical for areas such as Colorado and Utah. Average values near 80 percent relative humidity are typical for areas along the western coast of the United States such as San Francisco and Seattle. Many other areas of the United States experience average relative humidities between these values. Average temperatures, however, are typically lower than the $30^{\circ} \mathrm{C}$ used for the moisture reabsorption tests. For these additional tests, conditions of $30^{\circ} \mathrm{C}$ at 50 and 80 percent relative humidity were utilized. The temperature was fixed at $30^{\circ} \mathrm{C}$ in order to allow comparison of the effect of relative humidity only.

As shown in Table 3, significantly lower levels of moisture reabsorption were obtained using the lower-humidity conditions. For example, the dried Eagle Butte coal samples subjected to the 50 percent relative humidity environment exhibited moisture reabsorption and equilibrium moisture values between about 7 and 9 percent. These compare to values of 12 to 15 percent under 95 percent humidity conditions. Similarly, the dried Usibelli coals exhibited moisture reabsorption and equilibriurn moisture values between about 8 and 11 percent at 50 percent relative humidity compared to values between about 13 and 15 percent at 95 percent relative humidity. Lower levels of moisture reabsorption would be expected at the more typical average temperature conditions (between about 10 and $20^{\circ} \mathrm{C}$ ) in the regions of the United States discussed above.

Moisture reabsorption tests were also performed on the Eagle Butte and Usibelli feed coals following conventional oven drying at about $110^{\circ} \mathrm{C}$. Table 4 summarizes the moisture reabsorption characteristics of these samples. Moisture reabscrption values exhibited by feed coals which were dried at $110^{\circ} \mathrm{C}$ (about 16 percent) were slightly greater than those exhibited by the IFB-dried coal products shown in Tables 1 and 2 (typically 14 to 15 percent). However, equilibrium moisture values of the coals dried at $110^{\circ} \mathrm{C}$ were significantly greater (20 to 22 percent) than those of the IFB-cried coals shown in Tables 1 and 2 (13 to 16 percent). These results show that the inclined fluidized-bed drying conditions contribute to more stable product characteristics in terms of equilibrium moisture.

Additional moisture reabsorption tests were performed on compressed pellets prepared at WRI from dried Eagle Butte and Usibelli coals. Table 5 summarizes the results. Due to limited sample availability, a single pellet (about 1.5 -inches in diameter) of each coal type was broken to perform both the moisture reabsorption and equilibrium moisture determinations. Although an attempt was made to prepare two large segments from each pellet, some additional breakage occurred. As a resu: dditional surface area was created. The compressed pellets exhibited reduced moisture reabsorption compared to the powdered, dried coals shown in Tables 1 and ?. Even lower levels of moisture reabsorption would be expected when testing unbroken, large pellets. 


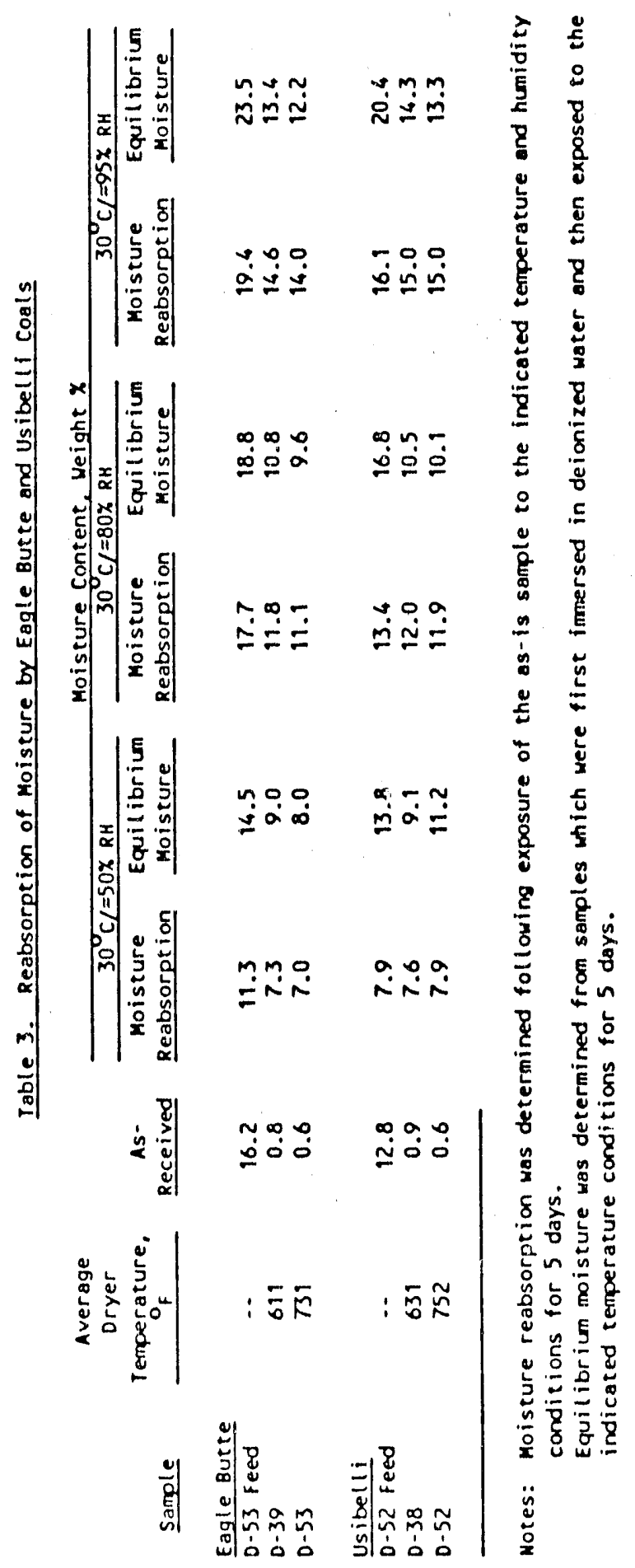


Table 4. Moisture Reabsorption Characteristics of Oven-Dried Eagle Butte and Usibelli Coals

\begin{tabular}{cccc} 
& \multicolumn{3}{c}{ Moisture Content, Weight $q$} \\
\cline { 2 - 4 } \multicolumn{1}{c}{ Sample } & $\begin{array}{c}\text { Oven } \\
\text { Dried }\end{array}$ & $\begin{array}{c}\text { Moisture } \\
\text { Reabsorption }\end{array}$ & $\begin{array}{c}\text { Equilibrium } \\
\text { Moisture }\end{array}$ \\
Eagle Butte & $<1.0$ & 16.4 & 21.9 \\
Usibelij & 0.6 & 16.4 & 20.3
\end{tabular}

Table 5. Moisture Reabsorption Characteristics of Compressed Eagle Butte and Usibelli Dried coal Pellets

\begin{tabular}{|c|c|c|c|}
\hline Sample & $\begin{array}{c}\text { As- } \\
\text { Received }\end{array}$ & $\begin{array}{c}\text { Moisture } \\
\text { Reabsorption }\end{array}$ & $\begin{array}{l}\text { Equilibr } \\
\text { Moistur }\end{array}$ \\
\hline $\begin{array}{l}\text { Eagle Butte } \\
\text { Usibelii }\end{array}$ & $\begin{array}{l}2.3 \\
0.8\end{array}$ & $\begin{array}{l}12.1 \\
12.0\end{array}$ & $\begin{array}{l}10 . \\
10 .\end{array}$ \\
\hline
\end{tabular}

\section{DUSTINESS}

Eagle Butte and Usibelli coal feeds and dry products were characterized for dustiness using an opacity meter. Figures 4 and 5 show dust test results for the two coal feeds and for selected test products which represent lower and higher inclined fluidized-bed dryer temperatures. As seen from the light transmission values in Figures 4 and 5, the Usibelli feed and dry products were less dusty than the Eagle Butte feed and dry products. Very little dust was observed in any of the dry coals. These results suggest that the finest fractions of the dry coal are entrained with the drying gas and removed from the inclined fluidized bed or are agglomerated with the coarser coal in the fluidized bed.

The curves shown in Figures 4 and 5 are typical for the feed and dried samples evaluated during the program. Values of light transmission at fixed time intervals after dropping the samples into the test column ( 0.25 and 1.00 minute) were recorded for subsequent tabulation and comparison. Tables 6 and 7 summarize these results.

Different dryer feed samples obtained during the program were analyzed for dustiness, as shown in Tables 6 and 7. Some variation in dustiness of the feed samples was observed due to differences in surface moisture content and also possibly the particle size distribution. 


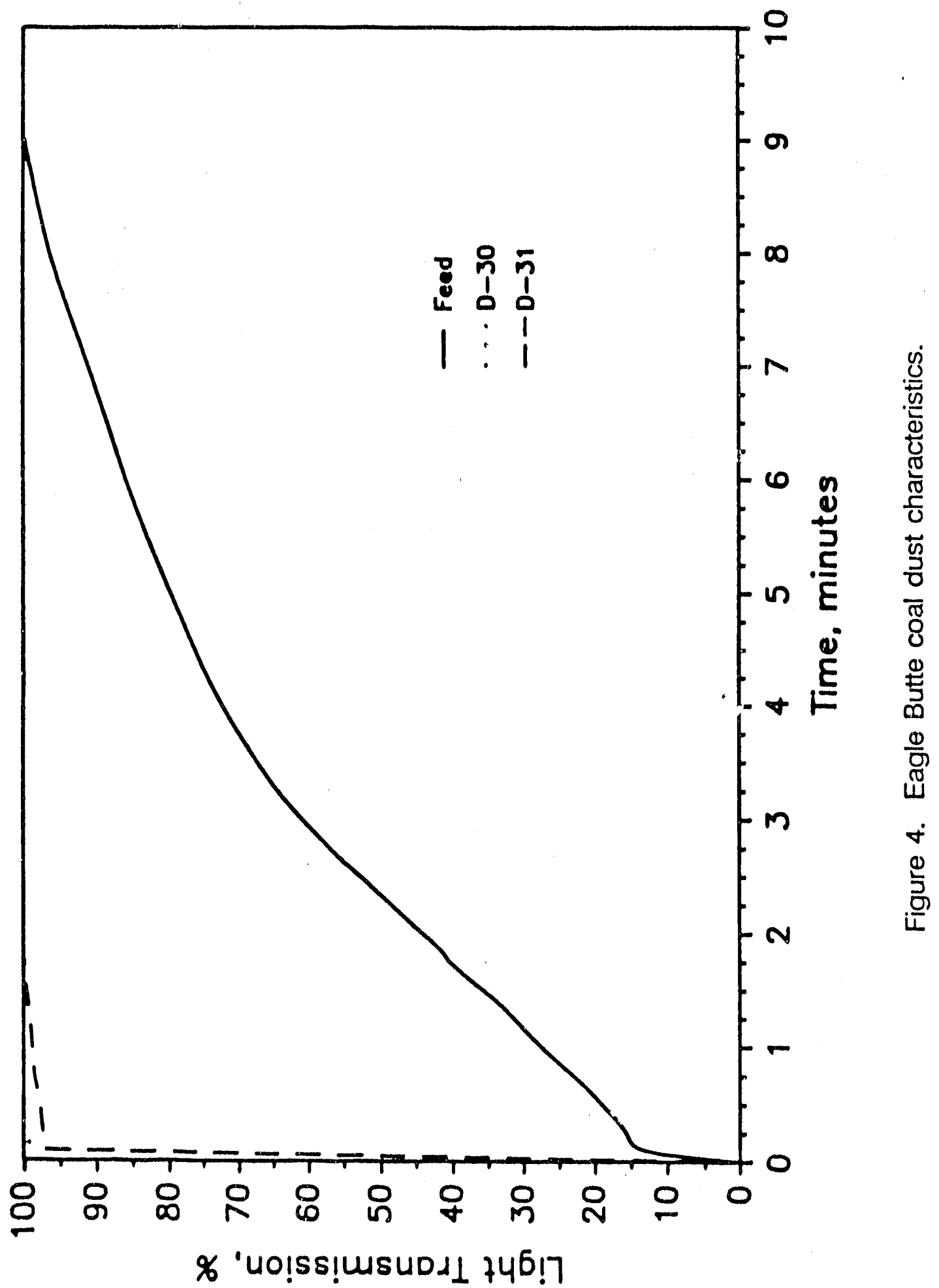




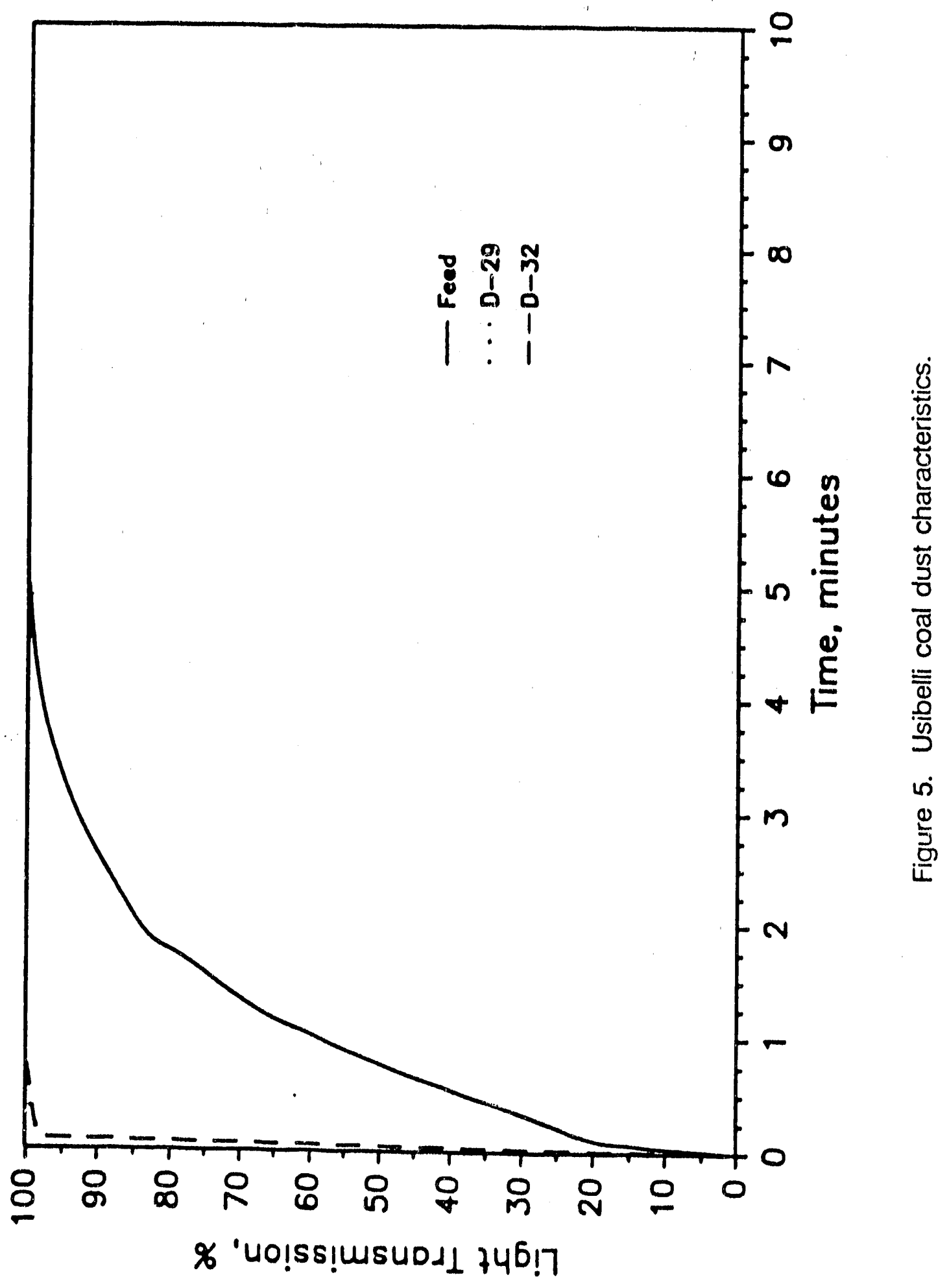


Table 6. Opacity Meter Measurements of Eagle Butte Coal Feeds and Dried Products

Sample

EB Feed

D-39 Feed

$D-45$ Feed

D-53 Feed

$D-2$

$D-8$

D $=14$

$D-30$

$D-31$

$D-37$

$D-39$

$D-41$

$D-45$

$D-47$

$D-49$

D-51

D-53

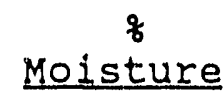

27.7

19.7

26.9

16.2

2.6

0.1

0.5

0.6

0.3

0.9

0.8

0.7

1.0

0.7

0.4

1.0

0.6

Light Transmission, $\frac{q \text { at } t=}{0.25 \text { Minute } 1.0 \text { Minute }}$

\section{Table 7. Opacity Meter Measurements of Usibelli Coal Feeds and Dried Products}

\section{Sample}

USI Feed

$D-38$ Feed

$D-44$ Feed

D-52 Feed

$D-17$

$D-22$

$D-29$

$D-32$

$D-35$

$D-36$

$D-38$

$D-43$

$D-46$

$D-48$

$D-50$

$D-52$
Light Transmission, Moisture

20.3

14.3

15.9

12.8

0.6

0.3

0.7

0.1

0.7

0.8

0.9

0.4

0.5

0.3

0.6

0.6
16

6

26

5

96

95

100

98

95

75

75

92

74

95

65

76
28

11

41

100

100

98

100

99

98

35

86

95

86

97

81

88 
The test results confirmed that the dried coal products contained very low levels of dust compared to the feed coals. In general, the dried Usibelli coal samples exhibited lower dust levels than the dried Eagle Butte coal samples. Lower moisture contents in the feed coals led to greater amounts of dust generation, particularly for the Eagle Butte coal. Due to the lack of dust contained in most of the dried samples, correlation of process conditions with product dustiness could not be determined.

\section{SPONTANEOUS HEATING}

Spontaneous heating tendencies were determined as moisture-saturated oxygen was passed through a bed of coal under controlled conditions. Temperature increases in the coal bed due to moisture absorption or oxidative self heating were recorded during the test procedure.

Spontaneous heating tests were carried out using the feeds and selected dry coal products. Initial tests were performed to determine the sample size, starting temperature, and oxygen flow rates to provide self-heating data for the feed and product coals. For routine tests, a 300-gram, sample of $20 \times 50$-mesh coal was loaded into a Dewar flask. All samples indicated a strong initial temperature increase resulting from moisture absorption. In some cases, continued heating due to oxidation was observed. Based on the initial results, a starting temperature of $70^{\circ} \mathrm{C}$ using an oxygen flow of $160 \mathrm{~cm}^{3} / \mathrm{min}$ was selected for routine testing. Lower gas flow rates were tested; however, the higher flow provided greater resolution of the differences between samples in a shorter test duration.

Following the initial tests, additional measures were taken to reduce the possibility of oxidation of the coals during preparation for spontaneous heating tests.

Measurements of $\mathrm{pH}$ obtained from slurries of coal in deionized water were used as a relative indicator of the degree of oxidation. These measurements showed that a slight decrease in $\mathrm{pH}$ (probable increase in oxiclation level) occurred following forced-air drying of the coal feeds. An additional, greater decrease in $\mathrm{pH}$ was observed following heating in a vacuum oven during preparation for spontaneous heating tests. As a result of these measurements, all drying and heating times were reduced to the minimum required. Sample heating was carried out to the greatest extent possible using a nitrogen-purged vacuum oven.

Figures 6 and 7 illustrate typical self-heating curves produced under the conditions described above for the Eagle Butte and Usibelli coals, respectively. These are the same coals for which dustiness measurements are shown in Figures 4 and 5. As shown in Figures 6 and 7, all of the coals began to ignite except for the Usibelli feed coal. The results showed that self-heating susceptibility was greater for the IFBdried coals than for the feeds. Self-heating susceptibility was also greater for coals dried at higher temperatures. In general, the Eagle Butte coal exhibited greater susceptibility to spontaneous heating than the Usibelli coal. 


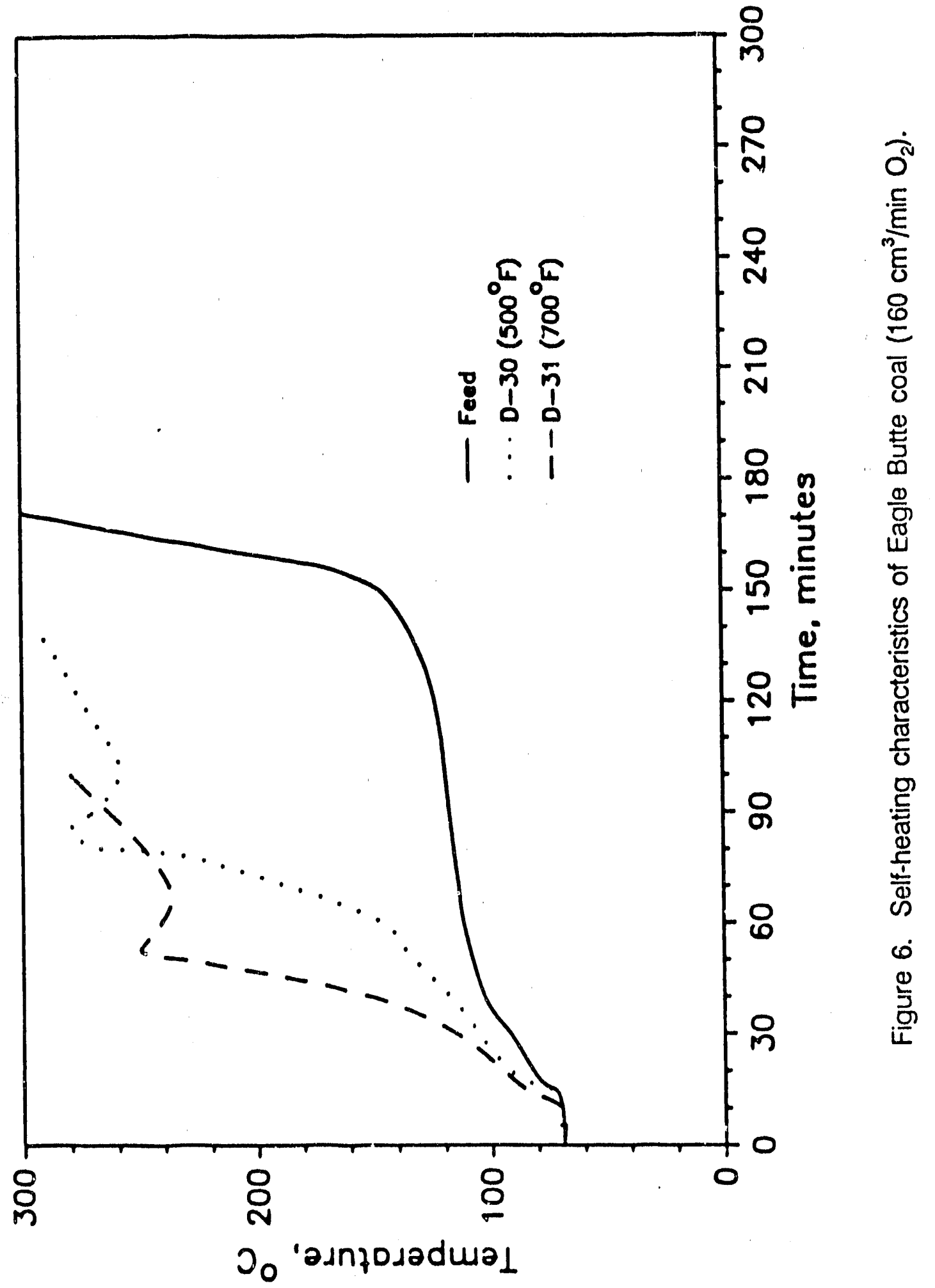




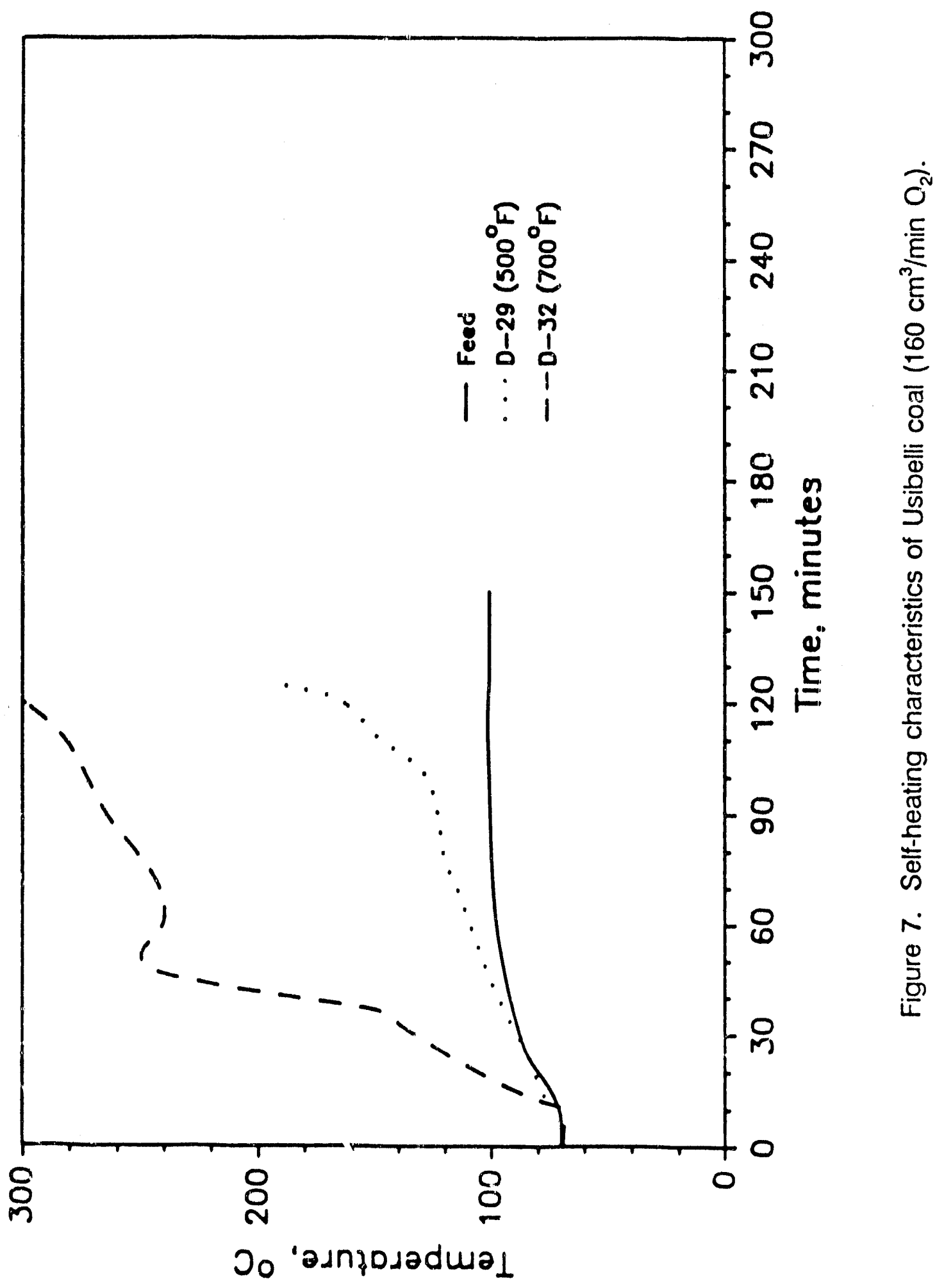


Tables 8 and 9 summarize all of the spontaneous heating data obtained under the same test conditions for the Eagle Butte and Usibelli coals, respectively. The selfheating data are tabulated in terms of the time required for the sample to reach $200^{\circ} \mathrm{C}$. These results also show that coals dried at higher temperatures are generally more susceptible to spontaneous heating than the feed coals and coals dried at lower temperatures. The effects of reactor slope on spontaneous heating characteristics could not be determined from the limited data.

Table 8. Self-Heating Characteristics of Eagle Butte coals

\begin{tabular}{|c|c|c|c|c|c|}
\hline Coal Type & $\begin{array}{l}\text { Test } \\
\text { No. }\end{array}$ & $\begin{array}{l}\text { Reactor } \\
\text { Slope }\end{array}$ & $\begin{array}{c}\text { Drying } \\
\text { Temperature, } \\
{ }^{\circ} \mathrm{F} \\
\end{array}$ & $\begin{array}{c}\text { Sample } \\
\text { Location }\end{array}$ & $\begin{array}{c}\text { Self-Heating } \\
\text { Time, Minutes } \\
\text { to Reach } \\
200^{\circ} \mathrm{C} \\
\end{array}$ \\
\hline Eagle Butte & $\begin{array}{l}-- \\
D-39 \\
D-53 \\
D-2 \\
D-28 \\
D-30 \\
D-31 \\
D-39 \\
D-41 \\
D-49 \\
D-51 \\
D-53\end{array}$ & $\begin{array}{r}-- \\
-- \\
-- \\
3 \\
6 \\
3 \\
3 \\
9 \\
12 \\
15 \\
15 \\
15\end{array}$ & $\begin{array}{l}-- \\
-- \\
-- \\
586 \\
666 \\
531 \\
695 \\
611 \\
603 \\
375 \\
589 \\
731\end{array}$ & $\begin{array}{l}\text { Feed } \\
\text { Feed } \\
\text { Feed } \\
\text { Product } \\
\text { Product } \\
\text { Product } \\
\text { Product } \\
\text { Product } \\
\text { Product } \\
\text { Product } \\
\text { Product } \\
\text { Product }\end{array}$ & $\begin{array}{r}160 \\
>150 \\
160 \\
145 \\
70 \\
70 \\
45 \\
75 \\
73 \\
107 \\
98 \\
60\end{array}$ \\
\hline
\end{tabular}

Table 9. Self-Heating Characteristics of Usibelli coals

\begin{tabular}{|c|c|c|c|c|c|}
\hline Coal Type & $\begin{array}{l}\text { Test } \\
\text { No. }\end{array}$ & $\begin{array}{l}\text { Reactor } \\
\text { Slope }\end{array}$ & $\begin{array}{c}\text { Drying } \\
\text { Temperature, } \\
{ }^{\circ} \mathrm{F} \\
\end{array}$ & $\begin{array}{c}\text { Sample } \\
\text { Location }\end{array}$ & $\begin{array}{c}\text { Time, Minutes } \\
\text { to Reach } \\
200^{\circ} \mathrm{C} \\
\end{array}$ \\
\hline Usibelli & $\begin{array}{l}-- \\
D-52 \\
D-29 \\
D-32 \\
D-35 \\
D-36 \\
D-38 \\
D-43 \\
D-48 \\
D-50 \\
D-52\end{array}$ & $\begin{array}{r}-- \\
-- \\
3 \\
3 \\
3 \\
6 \\
9 \\
12 \\
15 \\
15 \\
15\end{array}$ & $\begin{array}{l}-- \\
-- \\
494 \\
705 \\
611 \\
664 \\
631 \\
653 \\
364 \\
594 \\
752\end{array}$ & $\begin{array}{l}\text { Feed } \\
\text { Feed } \\
\text { Product } \\
\text { Product } \\
\text { Product } \\
\text { Product } \\
\text { Product } \\
\text { Product } \\
\text { Product } \\
\text { Product } \\
\text { Product }\end{array}$ & $\begin{array}{r}>150 \\
>180 \\
125 \\
40 \\
75 \\
52 \\
60 \\
60 \\
180 \\
106 \\
50\end{array}$ \\
\hline
\end{tabular}


Greater reactivity observed in the dry coal products prepared under a carbon dioxide atmosphere compared to feed coals could be due to the creation of fresh carbonaceous surfaces following the decarboxylation and mild pyrolysis encountered in the inclined fluidized bed. Subsequent gas or liquid phase treatment could potentially be utilized to deactivate these fresh surfaces in order to reduce spontaneous heating susceptibility.

Additional spontaneous heating tests were run to determine the effects of moisture absorption separately from the effects of oxidation. For these tests, 300 grams of Eagle Butte D-31 feed and dried product were exposed to moisturesaturated nitrogen at a flow rate of $160 \mathrm{~cm} / \mathrm{min}$ after equilibrating with dry nitrogen gas at about $70^{\circ} \mathrm{C}$. The feed coal was pre-dried to less than 1 percent moisture prior to the test. Maximum bed temperatures of 92 and $100^{\circ} \mathrm{C}$ were obtained for the feed and dried product, respectively. Weight gains of 2.3 and 1.6 percent were observed for the same samples during the tests. The actual average bed temperatures at the beginning of these tests were 68 and $73^{\circ} \mathrm{C}$ for the feed and dried coal, respectively. The greater starting temperature probably accounts for the greater temperature increase observed for the dried coal. Note that the dried coal reabsorbed less moisture than the feed coal. These tests did verify that the initial teriiperature increase observed during spontaneous heating tests is due almost entirely to moisture absorption.

\section{SURFACE AREA AND PARTICLE DENSITY ANALYSES}

Surface area and particle density determinations were performed on selected Eagle Butte and Usibelli feeds, products, and fines samples. Table 10 summarizes the results. Two sets of feed, product, and fines samples representing the two coal types, different dryer reactor slopes, and different drying temperatures were analyzed. In general, the surface areas of the products were observed to be somewhat lower than the feed coals. The entrained fines generally exhibited lower surface area than either the feed or the dried products. The Eagle Butte coal samples contained greater surface area than the Usibelli coal samples. Standard surface area analysis procedures using nitrogen were conducted.

Particle densities were determined by displacement of kerosene. The values shown in Table 10 were calculated from densities determined using the as-received feeds and dried coals. This was accomplished by adjusting for moisture content. The calculated densities at the equilibrium noisture content were subsequently utilized for subsieve analyses, which are performed using a sedimentation technique. Equilibrium moisture contents of the entrained fines were estimated based on the average of the feed and product values. 


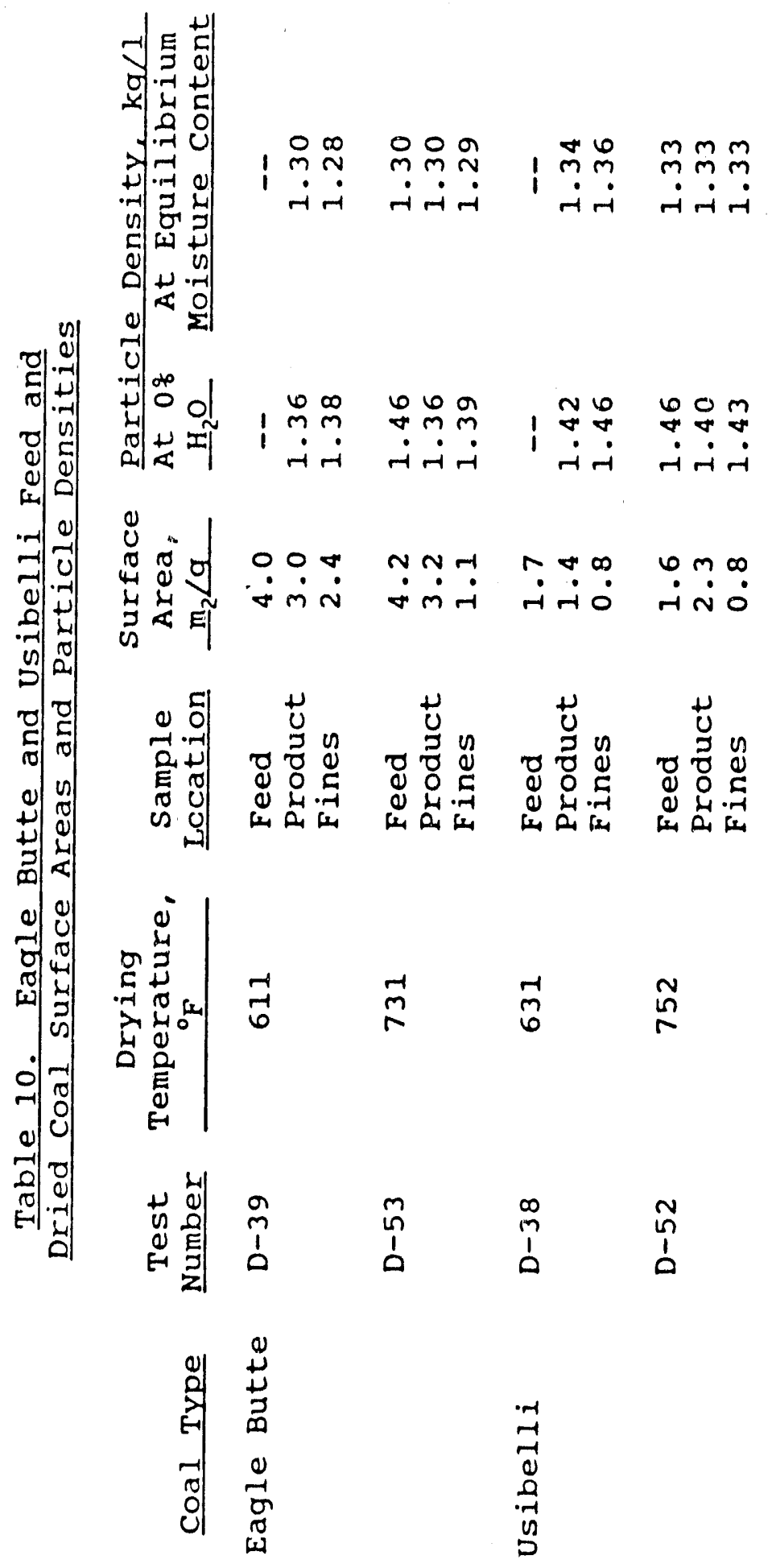


The Usibelii coals exhibited greater particle density values than the Eagle Butte coals. The coal densities at their equilibrium moisture contents were similar for thie feed, product, and fines samples within each coal type. The dry coal densities were greatest for the feed ccals (which, contain the greatest levels of equilibrium moisture). The lower dry coal densities exhibited by the roducts suggest that some change in structure takes place during drying. Removal of moisture, combined with inaccessibility of pores (plugged by tars), would result in reduced particle density values.

Additior.al surface area analyses were performed to help determine whether any relationships with dryer conditions and self-heating characteristics exist. Table 11 summarizes these results. Earlier spontaneous heating tests indicated that the feed coals were the most stable in terms of self-heating. The feed coals also exhibited relatively high surface area values, although surface area alone apparently cannot be used to predict self-heating characteristics. The higher drying temperatures generally resulted in the greatest self-heating rates. Dried coal surface area may depend on the drying temperature as well as residence time. Residence time will vary as a function of the reactor slope and gas flow rates. Mobilization of tars and subsequent cooling probably has a strong influence on the product suiface areas.

\section{PARTICLE SIZE ANALYSIS}

Particle size distributions were performed on feeds, products, and entrained fines frorn selected Eagle Butte and Usibelli coal drying tests. Tables 12 and 13 summarize the results. The inclined fluidized-bed dryer product and entrained fines analyses were combined using material balance data from the drying tests. The material balance was determined on the basis of the split between recovered product and entrained fines. The calculated size distributions for the combined product and fines were compared to the feed coal size distributions. Due to limited sample availability, it was assumed that the size distributions of feeds for tests D-39 and D.38 were the same as those for tests D-53 and D.52.

As indicated in Tables 12 and 13, the mass mean diameters of the calculated combined products and entrained fines were close to the measured values obtained on the feed coals. However, the particle size analyses showed that each coal feed degraded slightly in the coarsest size ranges (above about 300 microns). The amount of finest material (below about 15 to 20 microns) recovered in the products

and entrained fines was less than that fed to the inclined fluidized-bed reactor. This fine material may not have been collected by the cyclones or may have agglomerated with the coarser dry coal. Although the combined analyses do not include adjustments to the material balances for the greater loss of volatile matter from the product coals relative to the entrained fines, such adjustment does not significantly alter the combined size analyses. 


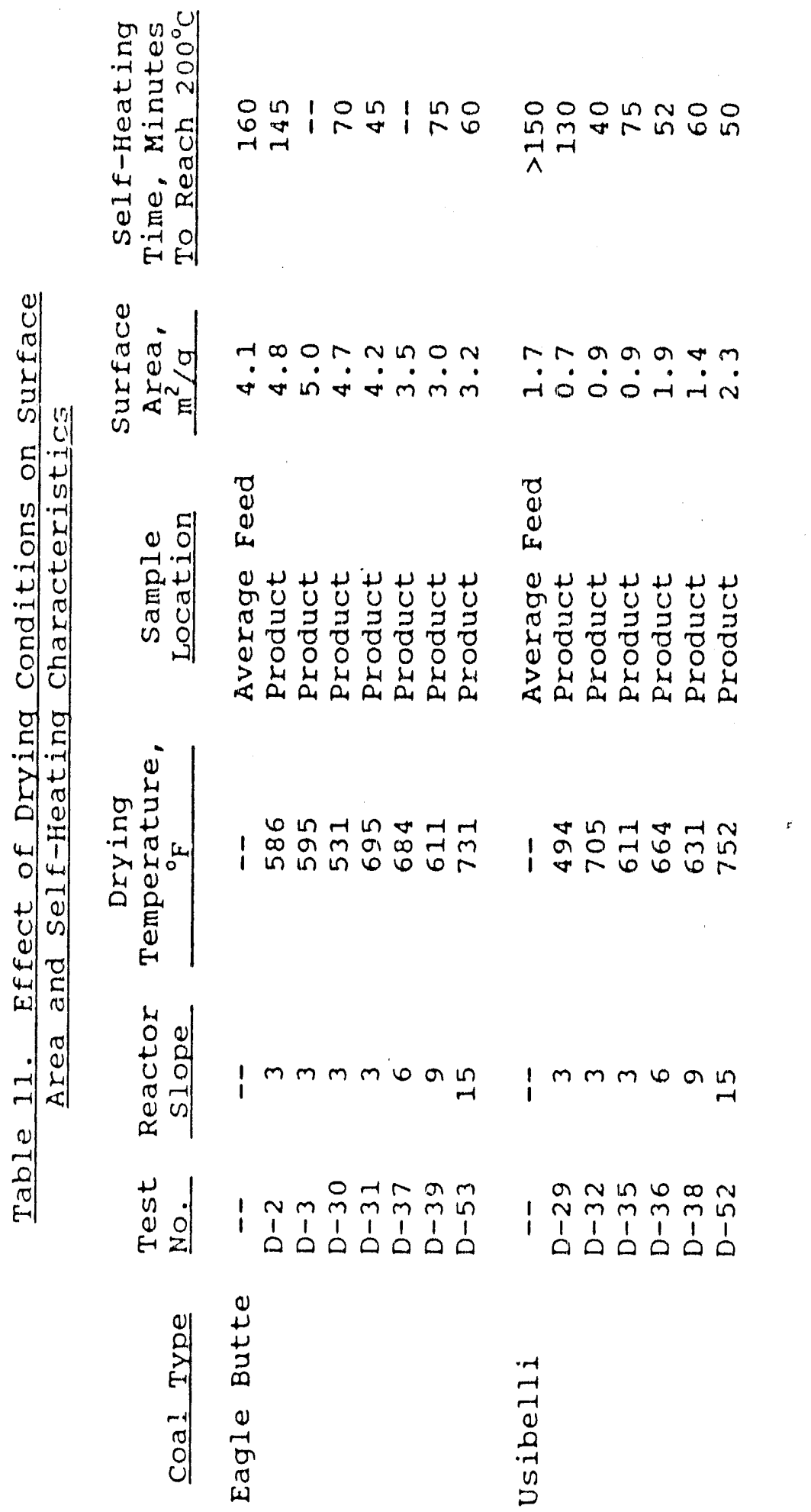




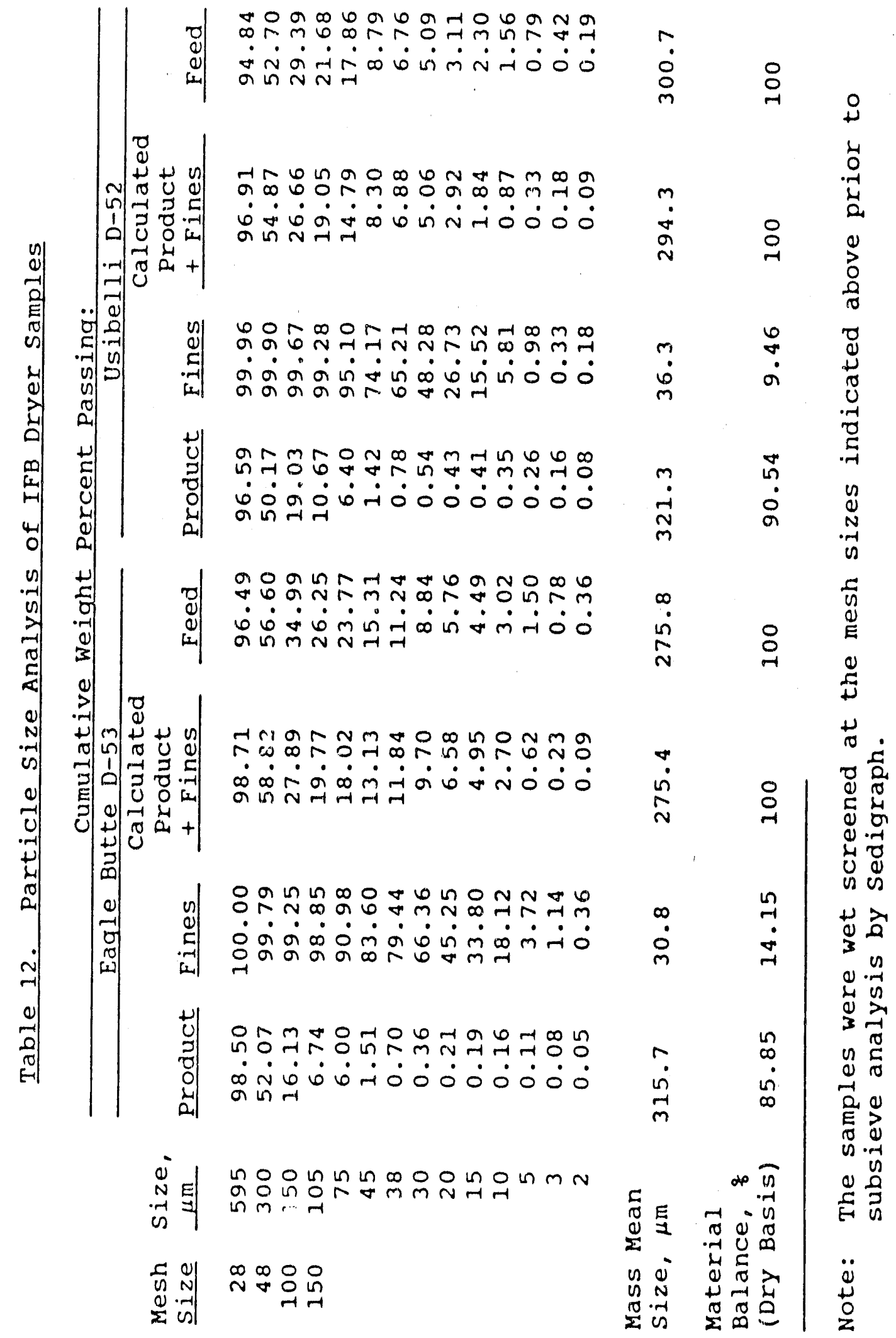




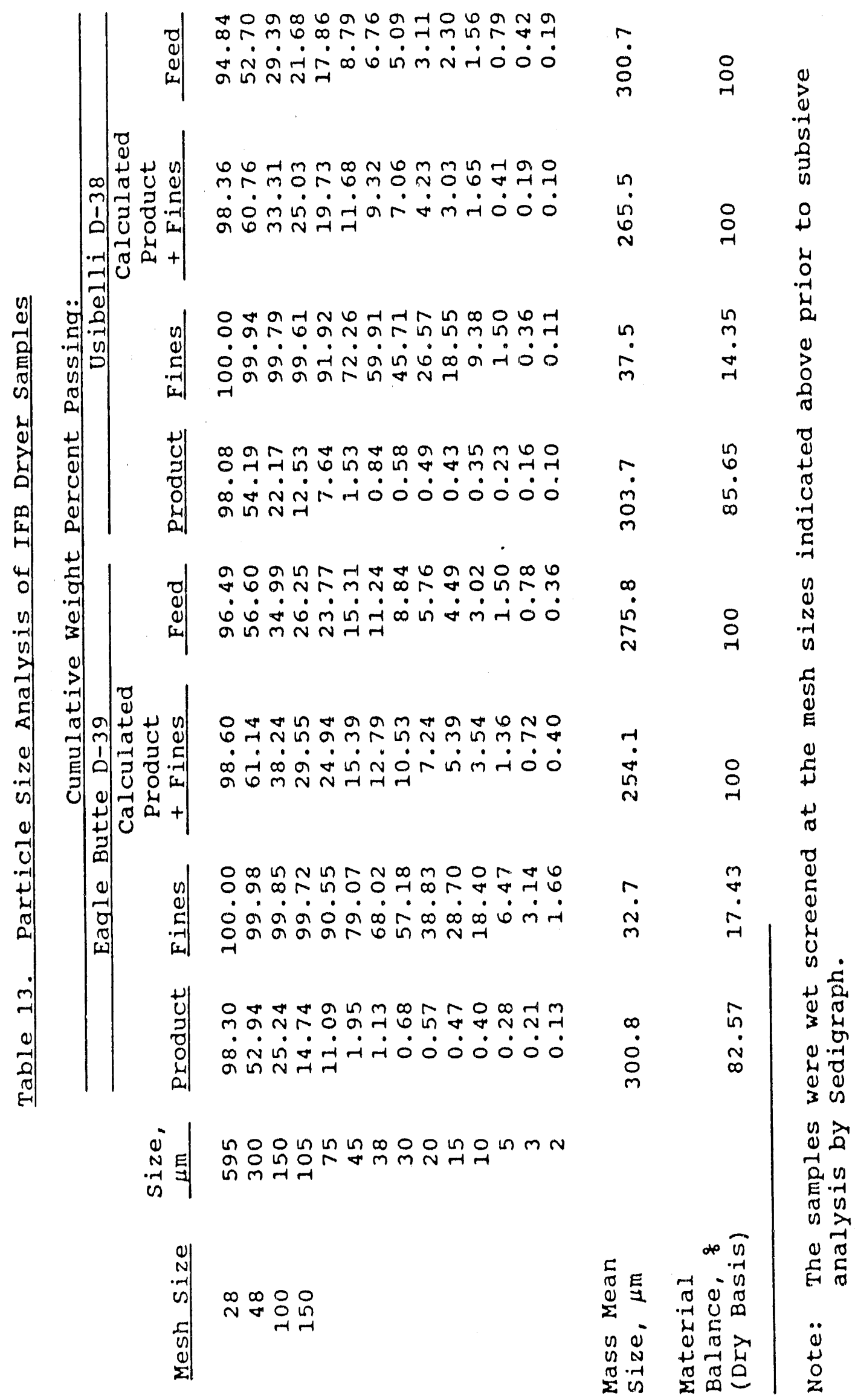


Surface area analyses which were reported earlier for the same samples shown in Table 12 were examined further. Calculated cornbined surface area analyses for the product and fines showed that for the Eagle Butte D-53 test, a reduction of surface area compared to the feed coal took place. The feed coal surface area was $4.2 \mathrm{~m}^{2} / \mathrm{g}$ versus the combined analysis of $2.9 \mathrm{~m}^{2} / \mathrm{g}$ for the product plus fines. For the Usibelli D-52 test, the opposite was observed. The feed coal surface area was $1.6 \mathrm{~m}^{2} / \mathrm{g}$ compared to $2.2 \mathrm{~m}^{2} / \mathrm{g}$ for the combined product plus fines. Again, the differences in surface area are probably due to a significant extent on the mobilization of tars during drying.

\section{EFFECT OF SURFACE TREATMENTS}

Attempts were made to spray coal-derived pitch/tar on selected samples in order to determine the effects on dustiness, moisture reabsorption, and spontaneous heating. While an intermittent spray was achieved, the atomization of the material was not sufficient to ensure adequate coverage onto dried coal using the small laboratory spraying nozzle. The material was heated to temperatures as great as about $165^{\circ} \mathrm{C}$. Pressures of up to 200 psi were used. Improved flow could probably be obtained using a larger-diameter spray nozzle.

A sample of a lighter coal-derived pitch/tar was obtained and additional spraying tests were conducted. The lighter material was a non-pourable, very thick material at ambient temperature. The lighter pitch/tar was successfully sprayed using a temperature of about $100^{\circ} \mathrm{C}$ and a pressure of about 200 psi. Table 14 summarizes the effects of spraying the coal-derived pitch/tar onto various samples of raw and dried Eagle Butte and Usibelli coals.

As shown in Table 14, the coal-derived pitch/tar did result in some reduction of dustiness of both the raw and dried coals. The "EB D39" and "USI D38" coarse + fines samples were mixtures of the Eagle Butte and Usibelli dried products and entrained fines, respectively, prepared using a ratio of 85:15 coarse:fines in each case. Opacity meter readings taken over a period of more than two weeks did not show a significant loss of effectiveness in dust suppression for the coal-derived pitch/tar.

The effects of the coal-derived pitch/tar on moisture reabsorption were also determined using selected samples. As shown in Table 15, only a slight reduction in moisture uptake resulted from the spraying. Much of the difference in moisture content observed between the untreated and treated coals during the tests can be attributed to the effect of the pitch/tar on moisture analyses based on weight loss at $107^{\circ} \mathrm{C}$. In any event, the pitch/tar reduced moisture reabsorption and equilibrium moisture values by less than 1 percent in each case examined. 
Table 14. Effect of spraying coalDerived Pitch/Tar on coal Dustiness

\begin{tabular}{|c|c|c|c|c|}
\hline \multirow{2}{*}{$\begin{array}{l}\text { Test } \\
\text { No. }\end{array}$} & \multirow[b]{2}{*}{ Coal Type } & \multirow{2}{*}{$\begin{array}{c}\text { Dosage, } \\
\text { Gallon/ } \\
\text { Ton } \\
\end{array}$} & \multicolumn{2}{|c|}{$\begin{array}{c}\text { Average Light } \\
\text { Transmission, } \\
\text { at Time }=\end{array}$} \\
\hline & & & $0.25 \mathrm{Minute}$ & 1.00 Minute \\
\hline-- & Eagle Butte Feed & 0 & 5 & 8 \\
\hline $\operatorname{CTS} / 1$ & & 1 & 9 & 17 \\
\hline $\mathrm{CTS} / 2$ & & 3 & 20 & 32 \\
\hline $\operatorname{CTS} / 3$ & & 5 & 30 & 44 \\
\hline- & Usibelli Feed & 0 & 23 & 53 \\
\hline $\operatorname{cTS} / 4$ & & 1 & 28 & 53 \\
\hline $\mathrm{CTS} / 5$ & & 3 & 31 & 56 \\
\hline $\operatorname{CTS} / 6$ & & 5 & 48 & 69 \\
\hline-- & $\begin{array}{l}\text { EB D39 Coarse } \\
+ \text { Fines }\end{array}$ & 0 & 42 & 70 \\
\hline $\operatorname{CTS} / 9$ & & 3 & 87 & 93 \\
\hline & $\begin{array}{l}\text { USI D38 Coarse } \\
+ \text { Fines }\end{array}$ & 0 & $100^{a}$ & $100^{\circ}$ \\
\hline CTS/ 8 & & 3 & $95^{\mathrm{a}}$ & $97^{\circ}$ \\
\hline
\end{tabular}

- Some fines were probably removed from these samples during handing and preparation prior to spraying.

Table 15. Effect of Spraying CoalDerived Pitch/Tar on Moisture Reabsorption

\begin{tabular}{|c|c|c|c|c|}
\hline \multirow[b]{2}{*}{$\begin{array}{l}\text { Test } \\
\text { No. }\end{array}$} & \multirow[b]{2}{*}{ coal Type } & \multirow{2}{*}{$\begin{array}{c}\text { Dosage, } \\
\text { Gallon/ } \\
\text { Ton } \\
\end{array}$} & \multicolumn{2}{|c|}{ Moisture content, $q$} \\
\hline & & & $\begin{array}{c}\text { Moisture } \\
\text { Reabsorption }\end{array}$ & $\begin{array}{l}\text { Equilibrium } \\
\text { Moisture } \\
\end{array}$ \\
\hline $\mathrm{CTS} / 2$ & Eagle Butte Feed & $\begin{array}{l}0 \\
3\end{array}$ & $\begin{array}{l}25.2 \\
24.9\end{array}$ & $\begin{array}{l}24.2 \\
23.4\end{array}$ \\
\hline $\mathrm{CTS} / 5$ & Usibelli Feed & $\begin{array}{l}0 \\
3\end{array}$ & $\begin{array}{l}20.9 \\
20.1\end{array}$ & $\begin{array}{l}19.5 \\
19.0\end{array}$ \\
\hline-- & $\begin{array}{l}\text { EB D39 Coarse } \\
+ \text { Fines }\end{array}$ & 0 & -- & -- \\
\hline $\operatorname{cTs} / 9$ & & 3 & 12.8 & 12.8 \\
\hline-- & $\begin{array}{l}\text { USI D38 Coarse } \\
+ \text { Fines }\end{array}$ & 0 & 13.2 & 13.1 \\
\hline $\operatorname{CTS} / 8$ & & 3 & 12.9 & 12.6 \\
\hline
\end{tabular}


The Eagle Butte and Usibelli coals which were used as feed for inclined fluidized-bed drying were sprayed with a petroleum-derived coal dust suppressant in order to compare performance with the coal-derived pitch/tar described above. The petroleum product used for the tests was Conoco coal treating oil, which has properties similar to a No. 6 fuel. The Conoco material was sprayed at a temperature of about $80^{\circ} \mathrm{C}$ using a pressure of about 200 psi. Table 16 shows the results.

Table 16. Effect of Spraying PetroleumDerived Liquid on Coal Dustiness

\begin{tabular}{|c|c|c|c|c|c|}
\hline \multirow{2}{*}{$\begin{array}{l}\text { Test } \\
\text { No. }\end{array}$} & \multirow[b]{2}{*}{ Coal Tyue } & \multirow{2}{*}{$\begin{array}{c}\text { Dosage, } \\
\text { Gallon/ } \\
\text { Ton } \\
\end{array}$} & \multicolumn{3}{|c|}{$\begin{array}{c}\text { Average Light } \\
\text { Transmission, } 8 \\
\text { at Time }=\end{array}$} \\
\hline & & & 0.25 Minute & 1.00 & Minute \\
\hline $\begin{array}{l}-- \\
\operatorname{cTS} / 2 \\
\operatorname{ccTO} / 1\end{array}$ & Eagle Butte Feed & $\begin{array}{l}0 \\
3^{a} \\
3^{b}\end{array}$ & $\begin{array}{r}5 \\
20 \\
12\end{array}$ & & $\begin{array}{r}8 \\
32 \\
22\end{array}$ \\
\hline $\begin{array}{c}-- \\
\text { CTs } / 5 \\
\text { CCTO/2 }\end{array}$ & Usibelli Feed & $\begin{array}{l}0 \\
3^{a} \\
3^{b}\end{array}$ & $\begin{array}{l}23 \\
31 \\
28\end{array}$ & & $\begin{array}{l}53 \\
56 \\
52\end{array}$ \\
\hline
\end{tabular}

- Coal-derived tar/pitch.

b Conoco coal treating oil.

As shown in Table 16, both the coal-derived pitch/tar and petroleum dust suppressants resulted in some overall reduction of dustiness of the raw coals. (These coals were dusty due to removal of surface moisture during preparation for inclined fluidized-bed drying.) The coal-derived tar was slightly more effective than the petroleum product fer this application, although neither product completely eliminated dustiness at the 3 gallon per ton dosage tested. 


\section{REFERENCES}

1. Jeglic, Michael F., "Laboratory Device for Evaluating Dust Control Agents", Journal of Coal Quality, Volume 5, Number 3, July 1986, pp. 104-107.

2. Schmoling, William A., King, Jeannette, and Schmidt-Collerus, Josef J., "Spontaneous Combustion Liability of Subbituminous Coals: Development of a Simplified Test Method for Field Lab/Mine Applications", Proceedings of the Symposium on Analytical Chemistry of Tar Sands and Oil Shale, American Chemical Society New Orleans Meeting, March 20-25, 1977, pp. 596-603.

3. Guin, James A., Curtis, Christine W., and Sahawneh, Basem M., "Laboratory Study of the Self-Heating Tendency of Coals and Their Pyrolysis Chars", Ind. Eng. Chem. Process Des. Dev., Volume 25, Number 2, 1986, pp. 543-546.

4. Paulson, L. E., Cooley, S. A., Wegert, C., and Ellman, R. C., "Experiences in Transportation of Dried Low-Rank Western Coals", Transactions of Society of Mining Engineers, AIME, Volume 260, December 1976, pp. 300-305.

5. Hand, John W., "Drying of Western Coal", Mining Congress Journal, May 1976 , pp. 30-32.

6. Anon., "Dried Coal is a Better Buy Than Wet", Coal Age, May 1980, pp. 149-158. 

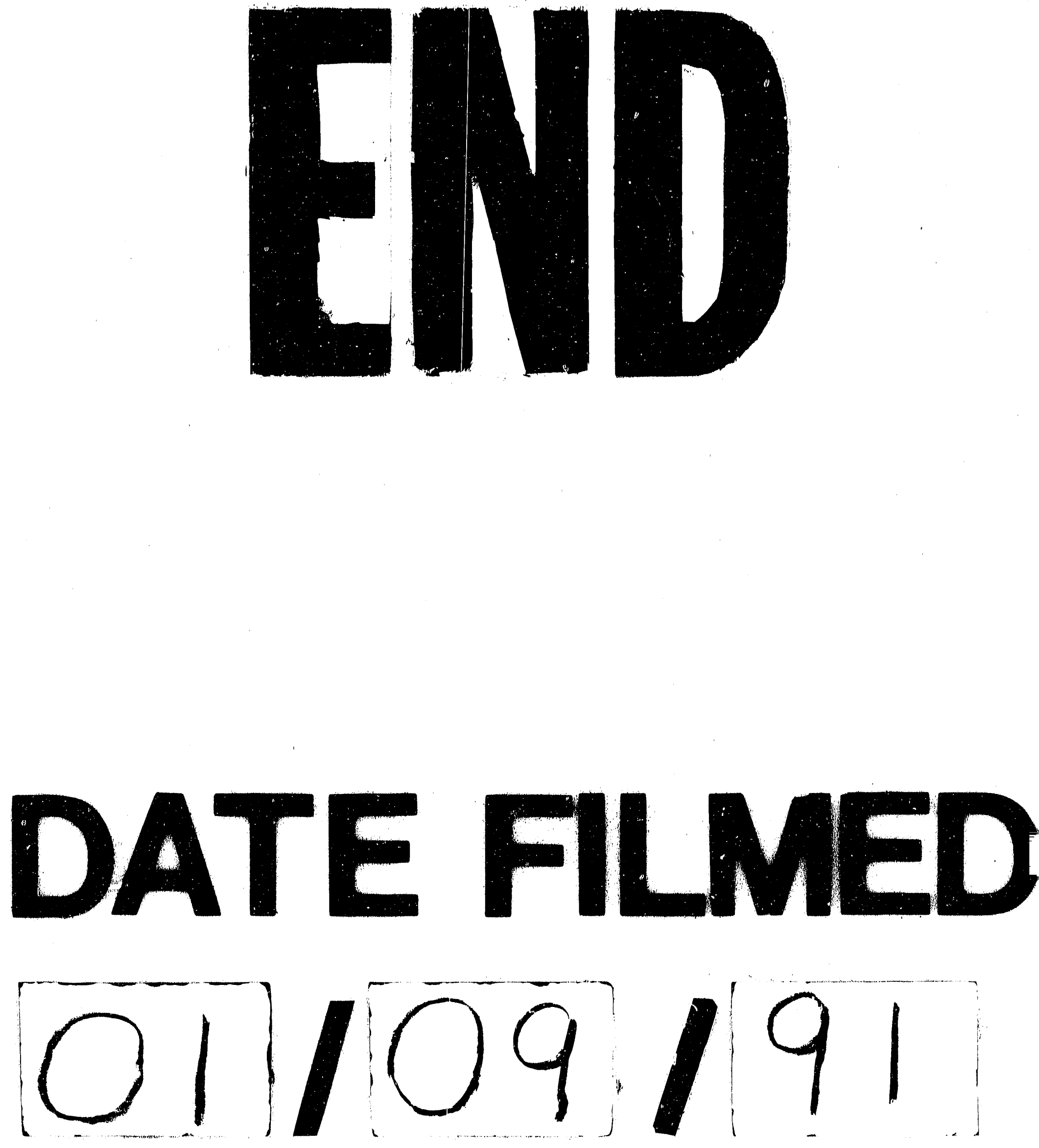
